1976

\title{
Maya Lithic Studies: Papers From the 1976 Belize Filed Symposium
}

Thomas R. Hester

Center for Archaeological Research

Norman Hammond

Center for Archaeological Research

Follow this and additional works at: https://scholarworks.sfasu.edu/ita

Part of the American Material Culture Commons, Archaeological Anthropology Commons, Environmental Studies Commons, Other American Studies Commons, Other Arts and Humanities Commons, Other History of Art, Architecture, and Archaeology Commons, and the United States History Commons

Tell us how this article helped you.

This Article is brought to you for free and open access by the Center for Regional Heritage Research at SFA ScholarWorks. It has been accepted for inclusion in Index of Texas Archaeology: Open Access Gray Literature from the Lone Star State by an authorized editor of SFA ScholarWorks. For more information, please contact cdsscholarworks@sfasu.edu. 


\section{Maya Lithic Studies: Papers From the 1976 Belize Filed Symposium \\ Creative Commons License \\ (c) $)(1)$ (9)}

This work is licensed under a Creative Commons Attribution-NonCommercial 4.0 International License 


\title{
MAYH LITHIC STUDIES:
}

\section{PAPERS FROM THE 1976 BELIZE FIELD SYMPOSIUM}

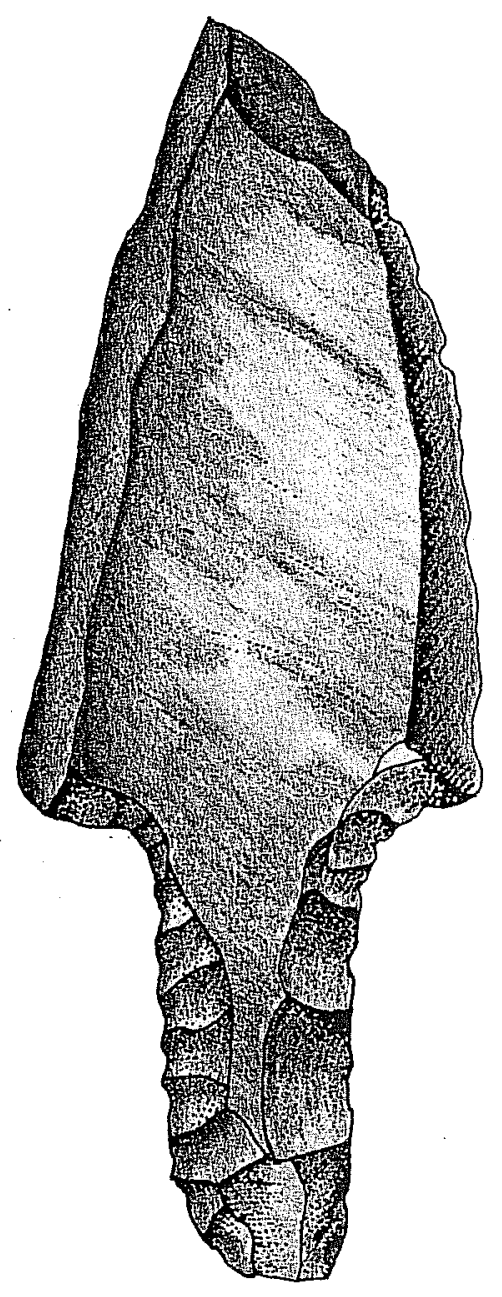

\author{
Edited by \\ Thomas R. Hester \\ and norman Hammond
}

Special Report Mo. 4

Center for Archaeological Research The University of Texas at San Antonio

1976 
Center for Archaeological Research

The University of Texas at San Antonio

78285

Thomas R. Hester, Director

Special Reports

Publications dealing with the archaeology of Texas and Mesoamerica.

No. 1 (1975) "Some Aspects of Late Prehistoric and Protohistoric Archaeology in Southern Texas" (By Thomas R. Hester and T. C. Hi11, Jr. $).(\$ 2.00+.10$ tax for Texas residents).

No. 2 (1976). "The Texas Archaic: A Symposium" (Edited by Thomas R. Hester). (\$4.00+.20 tax for Texas residents).

No. 3 (1976) "Papers on Paleo-Indian Archaeology in Texas: I" (Papers by T. R. Hester and W. W. Birmingham). $(\$ 3.00+.15$ tax for Texas residents).

No. 4. (1976) "Maya Lithic Studies: Papers from the 1976 Belize Field Symposium" (Edited by Thomas R. Hester and Norman Hammond). ( $\$ 8.00+.40$ tax for Texas residents $)$. 
MAYA LITHIC STUDIES:

PAPERS FROM THE 1976 BELIZE FIELD SYMPOSIUM

Edited by

Thomas R. Hester

and

Norman Hanmond

Special Report No. 4

Center for Archaeological Research

The University of Texas at San Antonio

1976 
The Center gratefully acknowledges the cooperation of the Department of Archaeology, Government of Belize (Joseph 0. Palacio, Archaeological Commissioner) and the Centre for Latin American Studies, Cambridge University. 
Preface (Thomas R. Hester and Norman Hammond) . . . . . . . . . . . . v

Symposium Papers

Islands of Lithic Knowledge Amid Seas of Ignorance

in the Maya Area (Payson D. Sheets). . . . . . . . . . . . . 1

Belize Lithics: Forms and Functions (Thomas R. Hester) . . . • . 11

Belize Lithics: "Orange Peel" Flakes and Adze Manufacture

(Harry J. Shafer). . . . . . . . . . . . . . . . . 21

Work in Progress at Colha, Belize, 1976 (Richard Wilk) . . . . . 35

Pre-Columbian Maya Development of Utilitarian Lithic

Industries: The Broad Perspective from Yucatan (Irwin Rovner). • . 41

The Terminal Preclassic Lithic Industry of the Southeast

Maya Highlands: A Component of the Protoclassic Site-Unit

Intrusions in the LowTands? (Payson D. Sheets) . . . . . . . . 55

Maya Obsidian Trade in Southern Belize (Norman Hammond). . . . . . 71

Long Distance Obsidian Trade: New Data from the Western Maya

Periphery (Jay K. Johnson) . . . . . . . . . . . . . . 83

Spatial Distribution of Flint and Obsidian Artifacts at

Tika1, Guatemala (Hattula Moholy-Nagy) . . . . . . . . . . . 91

Some Sociological Observations on Obsidian Production at

Kaminaljuyu, Guatemala (Joseph W. Michels) . . . . . . . . . 109

Arti-Fact or Fiction?: The Lithic Objects from Richmond

Hill, Belize (Arlene V. Miller)................ 119

Contributed Papers

An Obsidian Workshop at ET Pozito, Northern Belize

(Mary Neivens and David Libbey). . . . . . . . . . . 137

Notes on the Pre-Columbian Chert Industry of Northern Belize

(John Andresen)......................... 151

Metate Import in Northern Belize (Raymorid Sidrys and John

Andresen). . . . . . . . . . . . . . . . . . . 177 
As a result of intensified archaeological activity in northern Belize, and specifically the work of the joint British Museum-Cambridge University research project (directed by Norman Hammond), a variety of new data have been obtained on the prehistory of this region. Of the many sites that have been mapped, tested, or otherwise investigated in the past few years, one stands out as a major center of ancient Maya 1ithic technology. This is the site of Colha, located south of Orange Walk Town, along the highway between that town and Belize City. Personnel of the British Museum-Cambridge University Corozal Project began 1 imited research at the site in 1973. As a result of efforts then and since, parts of this extensive site have been mapped, some stratigraphic tests have been made, and controlled surface sampling and lithic analys is have been initiated (the latter through the hard work of Richard Wilk). These investigations, although preiminary in nature, were sufficient to indicate that Colha had indeed been a significant center of stone tool production for the Maya, from Middle Preclassic through Postclassic times.

Conversations about the site, among Hammond, T. R. Hester, H. J. Shafer and R. Wilk during 1975, led to the formulation of plans to hold a "field symposium" in Belize, in which a number of persons interested in Mesoamerican lithic studies could be brought together. The purpose of the symposium was to be two-fold: (1) to make an on-site inspection of Colha, to view the chert-working $10 \mathrm{ci}$ and vast exposures of workshop debris, and (2) to present a series of papers, followed by extensive discussion, in which the status of lithic research in the region could be assessed.

Through the sponsorship of the Center for Archaeological Research at The University of Texas at San Antonio, the field symposium was held in Orange Walk Town, Belize during the period of April 16-20, 1976. The program was organized by Norman Hammond, a Faculty Associate of the Center, in collaboration with Thomas Hester, the Center's director. Formal sessions were held at the Hotel Nuevo Mi Amor, and we are grateful to the management (especially Sr. E. Urbina) for their assistance in providing a meeting room and appropriate refreshments. The participants included Don E. Crabtree, Norman Hammond, Thomas R. Hester, Jay K. Johnson, Joseph W. Michels, Arlene V. Miller, Hattula Moholy-Nagy, Harry J. Shafer, Payson D. Sheets and Richard Wilk; Irwin Rovner presented a paper in absentia. Each of the participants presented a formal paper, revised versions of which are published in this volume.*

During the three days of the symposium, part of each day was occupied by the presentation of papers, while the remainder was spent in visits to archaeological sites in the vicinity. Greatest emphasis was placed on

\footnotetext{
*Two papers dealing with Belize lithics have been submitted to the editors since the symposium. These contributions, by Ray Sidrys and John Andresen, are published here.
} 
a full day inspection of the lithic workshops of Colha. While at the site, the symposium participants were able to examine a number of individual workshops and the wide variety of 1 ithic debris exposed at these. Impromptu replicative experimentation utilizing nodules of the local chert exposed in a streambed was carried out by Crabtree, Sheets and Shafer. The participants also visited the ceremonial center of the site, and spent a good deal of time examining the extensive collection of stone tools belonging to John and Herbert Masson, the owners of the property on which CoTha is situated. The Masson family was extremely gracious to the conference participants and we are very grateful for their hospitality, including a magnificent lunch.

Apart from the day spent at Colha, other sites visited during the conference included the Richmond Hill locality (about which the participants were collectively skeptical; see Miller's paper in this volume) and the Classic major center of El Pozito being excavated by the University of the Americas. An obsidian workshop had been discovered at El Pozito just prior to our visit and the materials from this workshop were examined. $A$ paper has been written by Mary Neivens and David Libbey describing the workshop, and it is published in this volume. The Preclassic site of Cuel1o, being excavated by Hammond, was also visited, and 1ithics dating to 1000-2000 B.C. were examined.

The field symposium ended with a lengthy discussion of the status of Maya lithic studies, suggestions for a more unified approach and a more consistent terminology, and the identification of areas of knowledge, and similarly, areas of ignorance in the field of Maya lithics in terms of time, space, materials and technology. It was also agreed that the site of Colha deserved long-term, detailed research. Crabtree described the site as "one of the most important lithic sites in the world", and it was commonly felt by participants in the field symposium that research at this site would yield a wide variety of new insights into Maya 1 ithic technology. A proposal for long-term research at Colha was being prepared at the time this volume went to press.

There are many to whom we are grateful for support and aid during and after the field symposium. We again thank Sr. Urbina of the Hotel Nuevo Mi Amor, and the Masson family, owners of the site of Colha. His Excellency the Governor of Belize, Mr. Richard Posnett, opened the conference and attended the session at Colha. Mr. Joseph Palacio, Archaeological Commissioner for the Government of Belize, provided the assistance of his office and welcomed participants. Belize Sugar Industries made available the swimming pool at Tower Hill, near Orange Walk Town, through the courtesy of Mr. F. J. C. Curtis, O.B.E. Norman Hammond's field crew at Cuello, with the generous aid of Harold B. Haley, provided the conference participants with a party on the last evening. Kathy McCauley, secretary for the Center for Archaeological Research, and Jeanette Burch, typist for the Center, helped in report preparation.

Persons attending the conference in addition to those participants listed above included: Evelyn Crabtree, Gabrielle Michels, Mary Neivens, 
Jul iette J. Cartwright, Peter R. A. Barron, Ginny Schneider, Harold B. Haley, Elizabeth Graham and Duncan Pring.

Thomas R. Hester

The University of Texas at San Antonio

Norman Hammond

Centre of Latin American Studies,

Cambridge University, England

As editors of this volume, and on behalf

of the participants in the 1976 Belize

field symposium, we respectfully dedicate

this volume to Don $E$. Crabtree, in recognition

of his outstanding contributions to the study

of lithic technology. 


\title{
ISLANDS OF LITHIC KNOWLEDGE AMID SEAS OF
}

\author{
IGNORANCE IN THE MAYA AREA
}

Payson D. Sheets

\section{INTRODUCTION}

The purpose of this paper is to provide a brief summary of 1 ithic analyses in the Maya area, noting "islands of knowledge" amid "seas of ignorance". I shall use a geographic organization, beginning in the northern Maya lowlands and ending in the southern highlands. Length limitations eliminate many topics such as assessing what we know and need to know about trace element attribution studies and prehistoric trade, genera 1 technological analyses and Paleo-Indian research.

\section{SURVEY OF MAYAN LITHIC STUDIES}

This overview of what areas are well or poorly known in terms of chipped stone artifacts ("artifacts" includes implements and debitage) begins in the Yucatan Peninsula, continues southward into the Classic Maya core area, then shifts westward to the Is thmus of Tehuantepec. From there we can move eastward, examining 1ithic knowledge in the Maya highlands of ChiapasGuatemala-El Salvador as well as along the adjoining Pacific piedmont and coast.

The Maya Lowlands

A small area of northern Yucatan is fairly well known in terms of lithics, extending from Mayapan to Chichen Itza, from the work of Proskouriakoff (1962) and Rovner (1974b). As the Dzibilchaltun monographs are published by the Middle American Research Institute over the next few years, our knowledge of chipped stone in this small area will increase further. But, this island of knowledge is surrounded by a vast sea of lithic ignorance extending to the south, east, and west. As we travel south the first locality with some information available on stone artifacts is Becan (Stoltman 1975; Rovner 1974a), and this information may be expected to increase as the Becan publications al so become available from the Middle American Research Institute.

Both the Mexican states of Campeche and Quintana Roo are 1ithic terra incognita. Moving southward and passing over the border into Guatemala, we find the situation greatly improved. Piedras Negras (W. Coe 1959) and Altar de Sacrificios (Willey 1972), both along the Usumacinta River in the western Peten, are quite well described and thoroughly illustrated. The Seibal artifact analysis will be available soon (G. Willey, personal communication 1975) and it will contribute considerable new information on the south-central Peten area. Jay Johnson's analysis of Palenque chipped stone is now available (1976), contributing considerable valuable information to our understanding of lithics in the extreme western portion of the Maya realm. 
The seminal studies of Uaxactun chipped stone (Ricketson and Ricketson 1937 ; Kidder 1947) are the major landmarks of published 1ithic information for the central Peten area. However, the first Tikal lithic analyses are now beginning to appear (Moholy-Nagy 1975; see also 0. Puleston 1969 and Becker 1973). With the final publication of the Tikal series, the central Peten should be one of the best understood areas in southern Mesoamerica.

Yaxha, to the southeast of Tikal, should become better known, from the lithic technological standpoint, as the lithic analyses of Ray Sidrys and Jay Johnson continue (N. He17muth, personal communication 1975).

The area to the east of Yaxha, central and northern Belize, is becoming one of the better understood areas. Willey's lithic analys is of the Barton Ramie artifacts is thorough and well illustrated (Willey et al. 1965). Northern Belize has received considerable attention as of late, particularly because of the efforts of Norman Hammond, Dennis Puleston, and their associates. Puleston (1975) has mentioned the possibility of Richmond Hill being a Paleo-Indian site, but this must remain only a possibility until detailed excavations, analyses, and chronometric dating have been conducted. Further studies of the calibre of Arlene Miller's (1975; see also this volume) examination of the Richmond Hill lithics are needed at this yet-enigmatic location.

The work of $\mathrm{N}$. Hammond and associates in northern Belize are beginning to yield a clearer picture of lithic patterning and variability as well as pointing out areas of critical1y-needed research. R. Wilk (1975) has performed a preliminary reconnaissance and analysis on the massive chert manufacturing center of Colha, and J. Andresen (n.d.; see also this volume) has contributed an overview manuscript of northern Belize chert implements. The small lithic collections from Lubaantun in southern Belize have recently been published by Hammond (1975), and the material from El izabeth Graham's project in Stann Creek District, central coast of Belize, is being analyzed by R. Wilk.

The southern Peten and southern Belize-eastern Guatemalan areas are poorly known (see Joyce 1932 for an early description of "eccentric" 1ithics from this area), but Copan, in the southeastern Maya area, is relatively we11 understood from the work of Longyear (1948, 1952). The current Copan project, directed by $G$. Willey, should yield a considerable increase in , 1ithic information. The same applies to the current project at nearby Quirigua, under the direction of $W$. Coe and R. Sharer.

Southern Maya Area

This summary of 1 ithic reports in the southern Maya area begins with the Isthmus of Tehuantepec and continues eastward through Pacific and highland Chiapas, Guatemala, and EI Salvador. These southern Mayan projects/reports tend to be smaller but more numerous and somewhat more evenly distributed across the Tandscape than those summarized above for the lowlands.

The work of Wal1rath (1967) and Lee (1969) have contributed to 1ithic 
knowledge of Towland Oaxaca (Isthmus of Tehuantepec) and Towland Chiapas respectively. MacNeish and Peterson (1962) encountered early Archaic lithics in the Santa Marta Cave near Tuxtla Gutierrez, and reported them extensively. Other than these three studies, little is known until we reach the Guatemalan frontier.

Just inside the Guatemalan border, along the Pacific coast, is the OcosLa Victoria area subjected to the ecologic scrutiny of M. Coe and Flannery (1967). Some mention of lithic artifacts is made by them. J. Graham's and R. Heizer's current work at Abaj Takalik on the Pacific piedmont $50 \mathrm{~km}$ east of 0 cos should yield at least Preclassic lithic materials. Bilbao, similarly situated but farther east, yielded chipped stone implements which Parsons (1969) described briefly.

In the highlands of Guatemala, Woodbury and Trik (1953) provide us with an extensive analysis of Zaculeu 1ithic artifacts. Kidder analyzed the artifacts of Zacualpa (1948) and Nebaj (Smith and Kidder 1951), two highTand sites east of Zaculeu.

The central Guatemalan highlands are quite well known, based on the work of Kidder at Kaminaljuyu (Kidder, Jennings and Shook 1946; Shook and Kidder 1952) and from the recently completed fieldwork of Sanders and Michels (also see Michels' article, this volume). M. Coe and Flannery (1964) presented a valuable description of the El Chayal obsidian outcrop just northeast of Kaminaljuyu (but see Sheets 1975a and Michels 1975 for comments on their interpretations). M. Coe (1960) also describes a Paleo-Indian point from San Rafael, near Guatemala City.

Sidrys et al. (1976) recently visited a number of obsidian outcrops and their associated workshops in the Maya highlands. Their locational, descriptive, and analytic data are a contribution to our understanding of aboriginal quarrying and trade.

An extensive analysis of the chipped stone from Beleh (Chinautla Viejo) is contributed by Hester (1975) as a portion of L. Feldman's research. Brief analyses of small lithic samples collected by Feldman along the Motagua River and in the southernmost corner of Guatemala were performed by Sheets $(1975 b, 1975 d$, n.d.).

The massive obsidian outcrop of Ixtepeque and the associated processing site of Papalhuapa were described by Graham and Heizer (1968) and more recent7y by Sidrys et al. (7976).

The Chalchuapa area is fairly well understood, both at the site of Chalchuapa itself (Sheets 1974, 1975c) and at the rural Bustamante Site (Sheets 1972). Chalchuapa area core-blade technology recently was found to be representative, in most respects, of lithic technology in the central and western areas of El Salvador (Sheets 1976:29-32). The investigations of E. W. Andrews V at Quelepa, in eastern El Salvador, wiTl extend our Tithic understanding into a poorly known area. The Quelepa report will be published soon in the Middle American Research Institute series from Tulane (Andrews, personal 
communication 1976). The area of northern El Salvador and all of Honduras except Copan is virtually terra incognita as far as lithics are concerned.

Mention should be made in this brief review of the Mayan lithic literature of other summaries which are available. Woodbury (1965) and W. Coe (1965), in their reviews of highland and lowland Maya artifacts, do give brief attention to 7 ithics. In an earlier article W. Coe (1955) reviewed the pitfalls inherent in Paleo-Indian research in the Maya area. Contemporary researchers would do well to carefully consider this caveat. Also, I recently reviewed the Southern Mesoamerican-Central American lithic 1iterature on a topical basis, noting shortcomings and lacunae (Sheets 1977). Finally, typological summaries are available in the comparison sections of the major site reports mentioned above. Particularly extensive typological summaries can be found in Kidder (1947), Willey (1972), Willey et al. (1965), Sheets (1974), and W. Coe (1959).

\section{NEEDS FOR FUTURE RESEARCH}

The needs for future research are numerous; in fact the needs are so vast and varied as to be discouraging, were it not for the fact that lithic analysis is rapidly becoming an integral component of Mesoamerican research programs.

From this survey we can see a number of geographic gaps where $7 i$ thic know1edge is weak or nonexistent. The most striking are Campeche, Quintana Roo, and southern and eastern Chiapas in Mexico, the southern Peten and A1ta Verapaz in Guatemala, southern Belize, and virtually all of Honduras.

Topically, I believe the most underdeveloped approach of Mayan lithic studies at present is function. This is not surprising, given the size and condition of most $7 i$ thic samples, the number of variables intervening between implement abandonment and archaeologic recovery, and the rigorous demands of a sophisticated functional anatysis (cf. Odel1 1975).

Trace element analyses, which began in the 1960's, to attribute obsidian artifacts to sources, are contributing an important body of data which allow for reliable reconstruction of trade patterns. When combined with technological analyses yielding an understanding of what kind of exploitation and processing was occurring at what node along the manufacturing trajectory process, along with the changes which occurred through time, our knowledge of the processing and distribution of that valuable commodity wil1 be greatly enhanced. 


\section{REFERENCES CITED}

Andresen, J.

n.d. The Prehistoric Chert Industry of Northern Belize. Paper presented at the annual meeting of the Society for American Archaeology, St. Louis.

Becker, M.

1973 Archaeological Evidence for Occupational Specialization Among the Classic Period Maya at Tikal, Guatemala. American Antiquity 38:396-406.

Coe, M.

1960 A Fluted Point from Highland Guatemala. American Antiquity 25:412-413.

Coe, M. and K. Flannery

1964 The Precolumbian Obsidian Industry of El Chayal, Guatemala. American Antiquity 30:43-49.

1967 Early Cultures and Human Ecology in South Coastal Guatemala. Smithsonian Contributions to Anthropology 3.

Coe, W.

1955 Early Man in the Maya Area. American Antiquity 20:271-273.

1959 Piedras Negras Archaeology: Artifacts, Caches, and Burials. Museum Monographs. University Museum, University of Pennsylvania.

1965 Artifacts of the Maya Lowlands. Handbook of Middle American Indians 3:594-602.

Graham, J. and R. Heizer

1968 Notes on the Papalhuapa Site, Guatemala. Contributions of the California Archaeological Research Facility 5:101-125.

Hammond, $N$.

1975 Lubaantun: A Classic Maya Rea 1m. Monographs of the Peabody Museum, Harvard university 2.

Hester, T. R.

1975 The Obsidian Industry of Beleh (Chinautia Viejo), Guatemala. Actas, XLI Congreso Internacional de Americanistas I:473-488. 
Johnson, J.

1976 Chipped Stone Artifacts from the Western Maya Periphery. University Microfilms, Ann Arbor.

Joyce, T. A.

1932 The "Eccentric Flints" of Central America. Journal of the Royal Anthropological Institute 62:17-26.

Kidder, A.

1947 The Artifacts of Uaxactun, Guatemala. Carnegie Institute Washington, Publication 576.

1948 The Artifacts of Zacualpa. In: Excavations at Zacualpa, Guatemala, by R. Wauchope. Middle American Research Institute, Publication 14.

Kidder, A., J. Jennings, and E. Shook

1946 Excavations at Kaminaljuyu, Guatemala. Carnegie Institute Washington, Publication 561.

Lee, $T$.

1969 The Artifacts of Chiapa de Corzo, Chiapas, Mexico. Papers of New World Archaeological Foundation 26.

Longyear, $\mathrm{J}$.

1948 A Sub-Pottery Deposit at Copan, Honduras. American Antiquity 13:248-249.

1952 Copan Ceramics. Carnegie Institute Washington, Publication 597.

MacNeish, R. and F. Peterson

1962 The Santa Marta Rock Shelter, Ocozocoantla, Chiapas, Mexico. Papers of the New World Archaeological Foundation 14.

Michels, J.

1975 El Chayal, Guatema 1a: A Chronological and Behavioral Reassessment. American Antiquity 40:103-106.

Miller, A.

1975 A Study of Possible Explanations for Observed Damage on the Lithics from the Site of Richmond Hill, Belize. M.A. Thesis, Department of Anthropology, Washington State University, Puliman. 
Moholy-Nagy, $\mathrm{H}$.

1975 Obsidian at Tikal, Guatemala. Actas, XLI Congreso Internacional de Americanistas $1: 517-518$.

Ode11, G.

1975 Microwear in Perspective: A Sympathetic Response to Lawrence H. Keeley. World Archaeology 7:226-240.

Parsons, L.

1969 Bilbao, Guatema7a, Vo1. 2. Milwaukee Public Museum, Publications in Anthropology 12.

Proskouriakoff, T.

1962 The Artifacts of Mayapan. In Pollock et al. Mayapan, Yucatan, Mexico. Carnegie Institute Washington, Publication 619.

Puleston, D.

1975 Richmond Hi11: A Probable Early Man Site in the Maya Lowlands. Actas, XLI Congreso Internacional de Americanistas I:522-533.

Puleston, 0.

1969 A Workshop Tool Kit from Tikal, Guatema1a. Unpublished M.A. Thesis, University of Pennsylvania.

Ricketson, 0 . and E. Ricketson

1937 Uaxactun, Guatema1a: Group E - 1926-31. Carnegie Institute washington, Publication 477.

Rovner, I.

1974a Implications of the Lithic Analys is at Becan. Middle American Research Institute Publication $31: 128-132$.

1974b Evidence for a Secondary Obsidian Workshop at Mayapan, Yucatan. Newsletter of Lithic Technology 3:19-27.

Sheets, P.

1972 A Model of Mesoamerican Obsidian Technology Based on Preclassic Workshop Debris in El Salvador. Cerámica de Cultura Maya 8:17-33. 
1974 Differential Change Among the Precolumbian Artifacts of Chalchuapa, El Salvador. Ph.D. dissertation, University of Pennsylvania; University Microfilms, Ann Arbor. To be published by University of Pennsylvania Press, 1976, as Vol. II of The Prehistory of Chalchuapa, El Salvador (R. J. Sharer, ed.).

1975a A Reassessment of the Precolumbian Obsidian Industry of El Chaya 1, Guatema 1a. American Antiquity 40:98-103.

1975b The Obsidian (from the Terzuola site, Guatemala). In: L. Feldman, ed., Jade Workers in the Motagua Valley. Museum Briefs, University of Missouri Museum 17(7).

1975c Behavioral Analysis and the Structure of a Prehistoric Industry. Current Anthropalogy 16(3):369-391.

1975d A Study of a Few South Guatemalan Artifacts. In: L. Feldman, ed., Papers on the Xinca of Eastern Guatemala. Museum Briefs, University of Missouri Museum 19:17-24.

1976 Ilopango Volcano and the Maya Protoclassic. Report to NSF on the 1975 fieldwork. Manuscript in possession of the author.

1977 The Analysis of Chipped Stone Artifacts in Southern Mesoamerica: An Assessment. Latin American Research Review 12:(1), Spring 1977.

n.d. The Obsidian Artifacts of Sabana Grande, Guatemala. Museum Briefs, university of Missouri Museum, in press.

Shook, E. M. and A. V. Kidder

1952 Mound E-III-3, Kaminaljuyu, Guatemala. Carnegie Institution of Washington, Contribution 53.

Sidrys, R., Jr. Andresen, and D. Marcucci

1976 Obsidian Sources in the Maya Area. Journal of New World . Archaeology 1(5):1-13.

Smith, A. L. and A. V. Kidder

1951 Excavations at Nebaj, Guatemala. Carnegie Institution of washington, Publication 594.

Stoltman, $\mathrm{J}$.

1975 An Analysis of Chipped Stone Artifacts from Becan, Campeche, Mexico: A Case Study of the Value of Detailed Lithic Analyses in Complex Societies. Manuscript in possession of the author. 
Wa17rath, M.

1967 Excavations in the Tehuantepec Region, Mexico. Transactions, American Philosophical Society 57(2).

Wilk, R.

1975 Superficial Examination of Structure 100, Colha, 1975. In: N. Hammond, ed., Archaeology in Northern Belize. Centre of Latin American Studies, University of Cambridge.

Willey, G.

1972 The Artifacts of Altar de Sacrificios. Papers of the Peabody Museum, Harvard university 64(1).

Willey, G., W. BuTlard, Jr., J. GTass, and J. C. Gifford

1965 Prehistoric Maya Settlements in the Belize Valley. Papers of the Peabody Museum, Harvard University 54.

Woodbury, R.

1965 Artifacts of the Guatemalan Highlands. Handbook of Middle American Indians 2(1):163-179.

Woodbury, R. and A. Trik

1953 The Ruins of Zaculeu, Guatemala. Byrd Press, Richmond, Va. 


\title{
BELIZE LITHICS: FORMS AND FUNCTIONS
}

\author{
Thomas R. Hester
}

\section{INTRODUCTION}

In the symposium, this paper was designed to orient and stimulate the discussions regarding Belize chert industries. It was originally presented in two parts: (1) a commentary on the status of lithic studies in Belize; (2) a series of specific observations on a collection of chert artifacts from the site of Colha, as analyzed by H. J. Shafer. For the purposes of the symposium volume, Shafer's paper has been printed separately.

It should be emphasized at the outset that the author's background in Maya lithic studies is very 1 imited, having been confined up to this point to the areas of trace element and technological ana Tyses of Maya obsidian (cf. Hester 1972, 1975; Graham et al. 1972). However, I have worked extensively with chipped stone industries in North America, particularly in Texas and in the Great Basin area. Lithic research has greatly expanded over the past few years, and it is now standard practice for most North American archaeologists to devote considerable attention to lithics from their sites. Analyses include wear pattern studies designed to provide data on actual tool function, debitage analys is which permits a better perspective on the lithic manufacturing process, and the utilization of data derived from both functional and technological studies in an attempt to learn more about site function and intrasite behavioral patterns (a bibliography of such 1ithic research is presented by Hester and Heizer 1973).

An intensified concern with lithics as a source of behavioral information is beginning to penetrate into Mesoamerican archaeological research, a fact reflected by the nature of the papers published in this volume. The past seven or eight years have seen a greatiy accelerated effort on the part of many Mesoamerican specialists to provide more anthropologically-meaningful analyses of lithic samples (cf. Sheets 1975a). In particular, there have been numerous studies devoted to trace element analysis of obsidian, and the resulting data have made available new information on the nature of obsidian dispersion in Mesoamerica (a recently published synthesis of such studies can be found in Stross et al. 1976).

Still, Mesoamerica lags far behind North America in the quality of lithic analysis that is being done. One can argue that the highly complex sites of Mesoamerica offer a wide range of data for analysis, whereas many North American sites often yield little else than chipped stone. This is certainly true; however, I would counter that the integration of data. derived from lithic analysis with that obtained through studies of architecture, monuments, ceramics, long distance trade, intensive agriculture, and the 1ike, will eventually permit a fuller and more complete picture of ancient Mesoamerican life-styles.

\section{LITHIC STUDIES IN BELIZE}

Archaeological research in the Maya lowlands of Belize has tended to 
neglect 1ithics and 1ithic studies. Early papers, 1ike those of Franks (1877), Gray (1916) and Joyce (1932) were concerned with eccentrics or with individual specimens. This is a situation which has been considerably improved by the work of Willey and others in the Belize Valley (WiTley et al. 1965), by N. Hammond's Corozal Project (particularly the work of R. Wilk at Colha; see this volume), and by the research of UCLA students in northern Belize (see the papers by Sidrys and Andresen in this volume).

An illustration of the paucity of information on chipped stone tools from the Maya lowlands is reflected in the scant five or six pages devoted to them in a synthes is of Maya lowland artifacts prepared by W. Coe (1965). As just stated above, more work has been done since then, but 1ithic studies in the lowland area remain in the embryonic stage.

A great deal more emphas is has been placed on the analysis of obsidian. Two major areas of research have been technological studies and trace element analysis. Work has been done by Rovner, Sheets, Michels, Moholy-Nagy, the author, and others. Concepts have been developed as to the process of obsidian tool production and distribution, the function of specific tool forms (cf. Hester 1975), the nature of activities at a site (Sheets 1975b; Michels 1975), and there has been particular success in defining and deTimiting many of the significant obsidian sources in the Maya area (cf. Stross et al. 1976; Sidrys et al. 1976). Again, however, the area of Belize has not figured in most of this research (an exception is the work of Hammond 1972; see also this volume).

For the purposes of this symposium paper, it is perhaps most useful to restrict the discussion to implements fashioned from chert--the chipped stone artifacts of Belize and the adjacent Maya lowlands. Specifical7y, I would 7ike to briefly examine (1) the problem of artifact description; (2) the need for functional analys is of 7 ithic implements; (3) the need for studies of the Tithic manufacturing process; (4) the necessity for intensive studies at sites specifically related to the 1 ithic production process (also important in this regard is the relationship between the production site and the consumption/distribution of the products).

Early archaeological studies in Belize paid scant attention to lithic artifacts, although as I have previously noted, some exotic specimens were described and illustrated. There are, of course, a number of early reports which treat with stone implements in one fashion or another, but the general trend was to illustrate a few specimens and let it go with that (cf. Gann and Gann 1939; Ricketson 1929; Thompson 1939). In the report of Ricketson's (1929) research at Baking Pot, a number of eccentrically chipped chert artifacts are illustrated, along with 1 arge bifaces, discoid unifaces, and small bifaces that may be projectile points. None of these specimens was described in any detail.

The first really adequate descriptive studies of lowland Maya 1 ithics came with the work of Kidder (1947) in his report on artifacts excavated some years earlier at Uaxactun. Kidder distinguished between artifacts of utilitarian and ceremonial functions. Within the utilitarian category, 
further division was made on the basis of materials used in tool manufacture-- "implements of white flint", "implements of dark flint", and "implements of obsidian". The implements of white flint consisted mainly of tools used in what he suggested were chopping, pecking, rubbing, perforating, and scraping functions, and these functional attributions were used in describing each form. The chopping tools were termed "general utility tools", with "standard" and other forms. Basic descriptive data and illustrations were provided. What I find significant about Kidder's treatment of the stone tools is his evident concern for substantive data related to function. He was not content to call a tool a "chopper" simply because it looked like what most archaeologists thought choppers ought to look like. Rather, he scrutinized the edges of these implements, as well as those of the other tool forms, for evidence of use-wear and for possible methods of prehension and/or hafting.

The descriptive categories set forth by Kidder in 1947 have generally been followed in studies published since that time. They have been elaborated upon and some new categories added; in particular, lengthy treatments of stone tools have been presented by Coe (1959, for Piedras Negras), Willey et al. (1965, for the Belize Valley), and Willey (1972, for the artifacts of Altar de Sacrificios).

By way of review, I want to very briefly examine those descriptive categories put forth by. Willey et al. (1965) for the Belize Valley, confining these observations to what were termed "utilitarian implements of flint". of the 524 specimens in this category, 6\% were described as "knives or points", with stemmed, unstermed, and notched variants; both bifacial and plano-convex examples were noted.

"Choppers or General Utility Tools" (following a classification originally proposed by Kidder) constituted $44 \%$ of the sample. These are 1 arge ovate bifaces, often bearing indications of wear on one end.

The rubric "chisel-1ike tools" was used to describe $6 \%$ of the assemblage, and includes "adzes or planes" (both bifacial and unifacial) "bifacial gouges", and "smal1 bifacial chisels".

"Dri11s or punches" is a fourth category, representing $2 \%$ of the sample. Both "sma17" and "heavy" variants were reported.

"Scrapers" constituted $5 \%$ of the collection. These were subdivided into groups such as "triangular side-scrapers", "end and/or side scrapers" (with both large and small variants). "Prismatic end and side scrapers" were also described, and are made on blade-like chert flakes.

Other chipped stone tool categories include specimens which were either "choppers or cores" (19 of these showed wear evidence; 26 did not), a polyhedral chert core, unworked or slightly modified chert nodules, flake blades and flakes, rejects, and unidentifiable fragments.

In general, most of these categories evidence very good description, excellent illustrations, and contain comparative comments dealing with similar specimens elsewhere in the Maya area. There are no major criti- 
cisms on my part as to the adequacy of the Tithic descriptions; some categories, such as the flakes, are perhaps insufficiently treated, but the sample was small (and, to the authors' credit, they did carry out experiments in an effort to replicate the use-nicks observed on the flakes).

Thus, there are eight or nine major descriptive categories into which the Belize Valley lithics were sorted. Similar classifications were used earlier by Kidder, Coe and others, and in the subsequent Altar report by Witley (1972). Alt of these scholars seem to be talking about the same things when these various descriptive classifications are invoked. One could argue that these categories "communicate" well and that they have a respectable history of use among archaeologists working with Towland Maya artifactual remains.

Perhaps this is true, but it brings me to my second point. Do these descriptive terms have any substance, or do they reflect any sort of functional "reality"? Can these subjective terms be replaced by more meaningful labels reflecting the tool's actual use? Or, by the same token, can we provide better tests of the functional terms, such as "end and side scrapers", "chopper", etc., which currently exist in the 1 iterature?

The archaeologist now has available a series of research tools which would permit useful functional studies with Belize Tithics. Paramount among these is wear pattern analysis, at both the macroscopic and microscopic levels. Such research can, and should, be combined with replicative experiments in which tool forms are used in certain tasks and the resulting wear patterns then observed and recorded for comparison with archaeological specimens.

Use-wear observations have already been made at the macroscopic level, beginning with the work of Kidder (1947) and amplified in the various publications of Willey (cf. Willey et al. 1965; Willey 1972). Wilk (n.d.a) has conducted microscopic wear pattern studies of artifacts from the site of Barton Ramie in Belize (see also Wilk's n.d.b, microwear research on the lithics of Seibal, Guatemala). The potential for functional analysis with Maya chert tools has already been demonstrated by similar studies with Maya obsidian industries. For example, at Beleh, Guatemala (Hester 1975), microscopic wear pattern studies revealed that thinned bifaces which might be called projectile points by some archaeologists actually functioned as cutting tools or knives. Similarly, in some Mexican obsidian assemblages, such as one I studied from Michoacan (Hester n.d.), there are unifacial implements which can be technologically classified as "end scrapers", but which wear analysis revealed to have been used on both the ends and sides, most probably used in a cutting, rather than in a scraping mode.

Practically all of the existing Belize lithic categories are ripe for functional analysis. The "general utility" bifaces, described by some as choppers or possibly hand-axes, often exhibit wear, ejther as battering on edges or as polish on or near working edges. Bullard (1965:53) uses the term "celt" for this tool form. He reports battering and use-polish on specimens from San Estevan in northern Belize. According to Bullard 
the tool form is restricted to the Maya lowlands, and it is his belief that they were "primarily forest-clearing and wood-cutting tools" (probably hafted for such use). Bullard and Bullard (1965:28) present similar remarks. Significant samples of these tools need to be systematically studied for types and frequencies of wear patterns, and attempts should be made to replicate the wear evidence through controlled experimentation. The large, stemmed bifaces from Belize described by willey et al. (1965) as "points or knives" should also undergo similar examination; a projectile point shape does not necessarily equate with function.

The so-called "chisels" or "gouges" show wear, but we have no concrete evidence as to their actual function. Specimens termed "scrapers" may well have served in that fashion, but wear pattern studies might lead to the establishment of useful subdivisions within this classification. Willey (1972), in his study of Altar de Sacrificios 1ithics, making the following observation about scrapers: "...they are not well reported, and it is possible that they have often been discarded as little more than odd flakes or scraps." (p. 178). He was referring to a particular unifacial form that has been noted at Barton Ramie, Tikal, Uaxactun, Piedras Negras, and other sites. However, terribly little has ever been written about this tool form.

Systematic functional research with Belize lithics would enable archaeologists to not only establish more realistic classifications, but to also use these meaningful categories in discussing the utilization of chert implements in Maya society. Such studies would be especially valuable in the interpretation of a production site like Colha. Wilk (1973) used both descriptive and morphological classifications in his studies of the 1 ithics from that site, but repeatedly argued for wear pattern and functional research. Until such studies are done, it will be difficult to achieve the goals of explaining workshop activities, intrasite organization, and export mechanisms at the site.

A third area I have chosen for comment is the analysis of the lithic manufacturing process in Belize and lowland Maya chert industries. Here again, such studies have been carried out with obsidian assemblages, with the work done by Sheets (1972) serving as an excellent example. He has proposed a model which allows the archaeologist to evaluate obsidian specimens in terms of the sequence of manufacturing and use events--beginning with the quarrying phase, continuing through implement manufacture and utilization, and ending (usualiy) with the discard of the worn or broken tool.

No such model exists for the Belize chert industries (a post-symposium paper by Andresen presents a preliminary model; see this volume). In order to evaluate an industry or to develop a model to explicate it, one has to adequately sample and analyze flake debris, rejects, broken implements, etc., to record their provenience within a site, and, hopefully, to locate and study workshops and other functionally-specific areas within sites. In the past, flake debris has been consistently ignored at sites in Belize. Even those flakes used as tools have received rather cavalier treatment; e.g., Bullard's (1965:54) description of "worked flakes" at 
San Estevan: "Irregular flakes showing use chipping on one or more edges were found sparingly in deposits of all periods." Willey (1972) notes that at Altar de Sacrificios, flakes were not saved except when they were found in caches ( $p$. 180). He did report, however, that flakes were present in all parts of the site: At Barton Ramie, Belize, the "abundance of flint scrap and wastage" was reported, and an estimated 3000 specimens were tabulated but not analyzed. Willey et al. (1965:411) observed "... the presence of flint nodules in the house sites" and concluded that "these manufactures [of flint implements] were carried out at the Barton Ramie village" (ibid. 411). Obviously, the recovery and analys is of chert debris or debitage needs to be incorporated into future excavation projects. Some such studies have already been done. R. E. W. Adams (personal communication) informs me that James Stoltman has done a 1ithic debris analysis for the site of Becan in the Rio Bec area; Wilk (1973) has also provided cursory comments on lithic waste at Colha.

Similarly, tools broken during use, or those abandoned during the manufacturing process, need to be reported in order to establish the sequence of lithic tool utilization. Reports such as Barton Ramie (Willey et al. 1965) mention "uncompleted artifacts", but no descriptions are provided.

This brings me to a fourth and final point: we can perhaps best elucidate the lithic industries of Belize by beginning with the analysis of the production centers--the chert workshops. A number of such sites must be present in the Maya lowlands; for example, one workshop locality has been reported by Bullard (1960) near Santa Rosa on the Belize frontier. The participants in this field symposium will visit the site of Colha, where preliminary studies of a series of chert workshops has been initiated by R. Wilk (see this volume). To properly study a site as massive and as extensive as Colha will require a great deal of time, patience, and careful planning. Such an investment should be well worthwhile. The site has the potential to yield new and exciting data on the activities and organization of this major Maya chert-working center. Research at the site should also provide a better understanding of the manner through which the chert tools produced there were subsequently exported to Maya consumers.

\section{REFERENCES CITED}

Bullard, W. R., Jr.

1960 The Maya Settlement Pattern in Northeastern Peten, Guatemala. American Antiquity 25(3):355-372.

1965 Stratigraphic Excavations at San Estevan, Northern British Honduras. Royal Ontario Museum, University of Toronto, Occasional Paper 9.

Bullard, W. R., Jr., and M. R. Bullard

1965 Late Classic Finds at Baking Pot, British Honduras. Royal Ontario Museum, University of Toronto, Occasional Paper 8. 
Coe, W. R.

1959 Piedras Negras Archaeology: Artifacts, Caches and Burials. Mus eum Monographs, University of Pennsylvania.

$1965^{\circ}$ Artifacts of the Maya Lowlands. Handbook of Middle American Indians $3(2): 594-602$.

Franks, Mr.

1877 Some Stone Implements from Honduras and Turks and Caicos Islands. Journal of the Anthropological Institute of Great Britain and Ireland 6:37-40.

Gann, T. and M. Gann

1939 Archeological Investigations in the Corozal District of British Honduras. Bureau of American Ethnology, Bulletin $123(7)$.

Graham, J. A., T. R. Hester and R. N. Jack

1972 Sources for the Obsidian at the Ruins af Seibal, Peten, Gua temala. Contributions of the University of California Archaeological Research Facility 16:111-115.

Gray, St. G.

1916 On a Chipped Flint Implement Found in British Honduras. Man 16:154-155.

Hammond, N.

1972 Obsidian Trade Routes in the Mayan Area. Science 178:1092-1093.

Hester, T. R.

1972 Notes on Large Blade Cores and Core-BTade Technology in Mesoamerica. Contributions of the University of California Archaeological Research Facility 14:95-105.

1975 The Obsidian Industry of Beleh (Chinautla Viejo), Guatemala. Actas, XLI Congreso Internacional de Americanistas I:473-488.

n.d. Preliminary Notes on the Technological Analysis of Obsidian Artifacts from Villa Morelos, Michoacan, Mexico. In: Archaeological Studies of Mesoamerican obsidian (T. R. Hester, ed.). Ballena Press, Ramona, CA (in preparation).

Hester, T. R. and R. F. Heizer

1973 Bibliography of Archaeology I: Experiments, Lithic Technology and Petrography. Addison-Wesley Modules in Anthropology 29. 
Joyce, T. A.

1932 The "Eccentric" Flints of Central America. 'Journal of the Royal Anthropological Institute 62:17-35.

Kidder, A. V.

1947 The Artifacts of Uaxactun, Guatemala. Carnegie Institution of Washington, Publication 567.

Miche]s, J. W.

1975 El Chayal, Guatemala: A Chronological and Behavioral

Reassessment. American Antiquity 40(1):103-106.

Ricketson, 0. G., Jr.

1929 Excavations at Baking Pot, British Honduras. Carnegie Institution of Washington, Publication 403.

Sheets, P. D.

1972 A Model of Mesoamerican Obsidian Technology Based on Preclassic Workshop Debris in El Salvador. Ceramica de Cultura Maya 8:17-33.

1975a Behavioral Analys is and the Structure of a Prehistoric Industry. Current Anthropology 16(3):369-391.

1975b A Reassessment of the Precolumbian Obsidian Industry of E1 Chaya 1, Guatema 1a. American Antiquity 40(1):98-103.

Sidrys, R., J. Andresen, and D. Marcucci

1976 Obsidian Sources in the Maya Area. Journal of New World Archaeology 1(5):1-13.

Stross, F. H., T. R. Hester, R. N. Jack, and R. F. Heizer

1976 Chemical and Archaeological Studies of Mesoamerican Obsidians. In: Advances in Obsidian Glass Studies: Archaeological and Geochemical Perspectives (R. E. Taylor, ed.):240-258. Noyes Press, Park Ridge, New Jersey.

Thompson, J. E. S.

1939 Excavations at San Jose, British Honduras. Carnegie Institution of Washington, Publication 506.

Wilk, R.

19731973 Operations (CoTha). In: Centre of Latin American Studies, University of Cambridge, British Museum-Cambridge University Corozal Project (N. Hammond, ed.) :55-60. 
n.d.a Microscopic Analys is of Chipped Stone Tools from Barton Ramie, British Honduras. Estudios Cultura Maya 10: in press.

n.d.b Microwear Analysis. Appendix in: Artifacts of Seibal, Guatemala (by G. R. Wil7ey). Papers of the Peabody Museum, Harvard University: in press.

Willey, G. R.

1972 The Artifacts of Altar de Sacrificios. Papers of the Peabody Museum, Harvard University 64(1).

Willey, G. R., W. R. Bullard, Jr., J. B. Glass, and J. C. Gifford

1965 Prehistoric Maya Settlements in the Belize Valley. Papers of the Peabody Museum, Harvard University 54. 
BELIZE LITHICS: "ORANGE PEEL" FLAKES AND ADZE MANUFACTURE

Harry J. Shafer

INTRODUCTION

The subject of my study is the technological analysis of a small sample $(\mathrm{N}=26)$ of chipped stone artifacts recovered from the surface of Structure 100 at Colha, Belize. The majority of the items are curious elongated, curved flakes exhibiting one unifacially retouched convex edge. Emphas is will be placed on describing the technology of production and exploring the functional implications of these flakes. These interesting artifacts have been described and termed "orange peels" by Wilk (1976:165166). I will use the term "orange peel" flakes for the sake of continuity. In addition to the "orange peel" flakes, the sample contains five other artifacts which deserve special attention.

The major objectives of this brief study are (1) to provide a description of the sample; and (2) to provide a functional explanation of the "orange peel" artifacts. The descriptive work is accomplished by sorting the artifacts into morphological categories and providing a list of attributes used as sorting criteria. The second objective is accomplished by using the observed attributes of the "orange peel" flakes to hypothesize a reduction sequence which would explain the attribute patterns observed. This hypothesis was then tested in the field by searching for artifacts, at several debitage mounds at Colha, which could either have served as cores or which would otherwise provide clues to the purposes of the "orange peel" flakes. In essence, the hypothesis is that the "orange peel" flakes are the debitage resulting from edge rejuvenation of large unifacial adze-like utilitarian (and probably hafted) tools. This hypothesis, if confirmed, would explain the apparent abundance of the "orange peel" specimens and the near absence of cores from which they were derived, since the hypothesized cores or tools, once rejuvenated, would be carried back to the area where they were to be used. An alternative hypothesis proposed by both Wilk (1976) and Crabtree (personal communication), that the "orange peels" could themselves be specialized tools, will also be considered.

\section{THE SAMPLE}

The artifacts were divided into two major categories: "orange peel" flakes and possible cores for "orange peel" flakes.

"Orange Peel" Flakes ( $\mathrm{N}=22)$

The sample of artifacts described under this heading was subdivided into four categories; three of these may have functional implications in that initial, secondary and tertiary uniface retouch steps appear to be represented. Measurements taken include the length of the retouch flake which would provide the maximum width of the core (Fig. 1). The width is calculated by measuring from the flat surface from which the retouch flakes along the worked edge were struck to the maximum width of the 

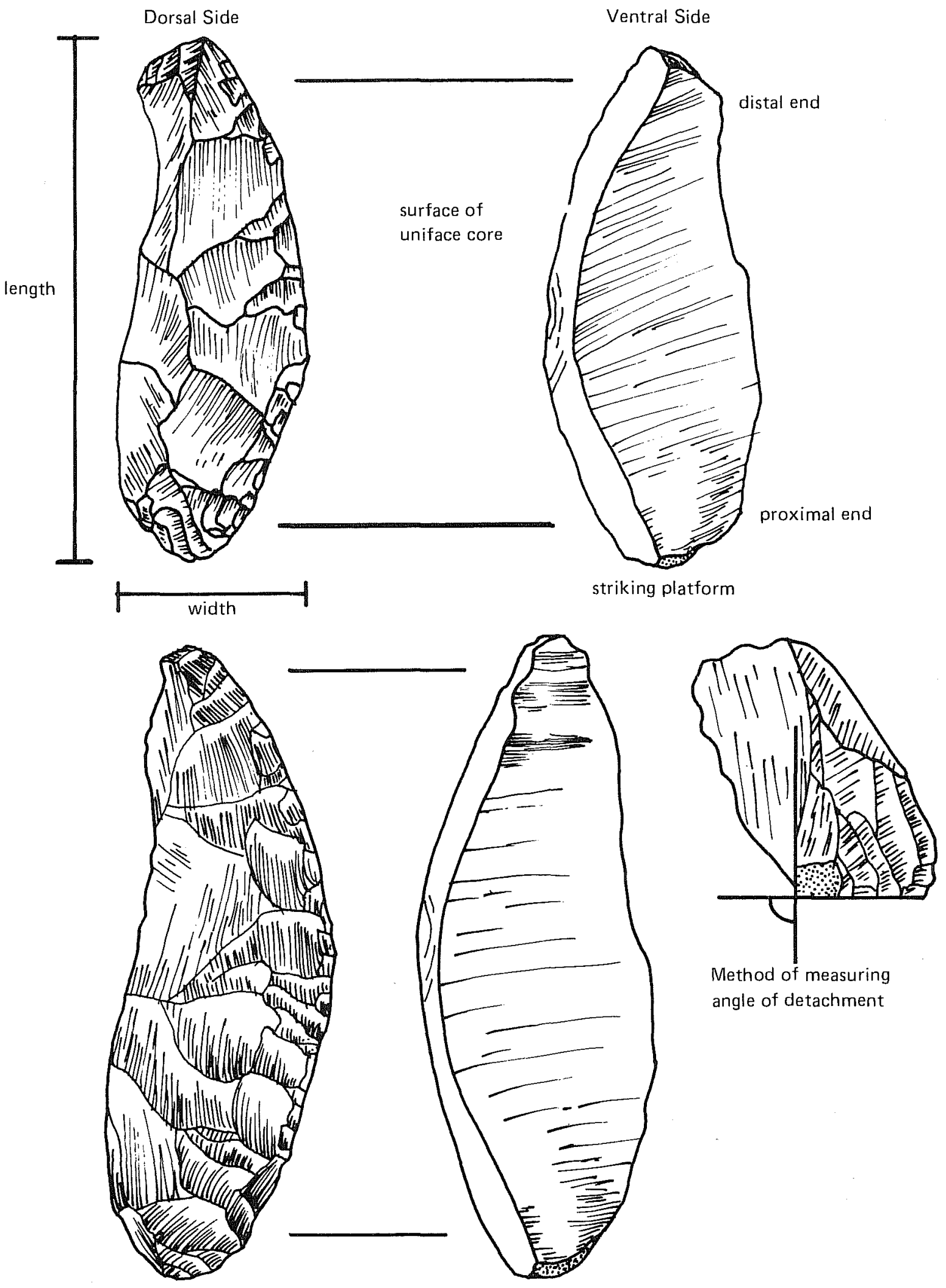

Category 2 "orange peel" flakes illustrating method of orientation

Figure 1. Category 2 "orange peel" flakes illustrating method of orientation and measurement. 
opposite edge (Fig. 1). This measurement will provide a minimum thickness of the core from which the "orange peel" flakes were derived. Edge angle measurements were made using a contact goniometer.

Category 1 ( $\mathrm{N}=3$; Fig. 2, top) Primary Removals: These are represented by three specimens; two of these exhibit all or significant portions of the bulb of force that resulted in the removal of the parent flake. Remnants of the weathered cortex surface are retained along the outer edge. However, much of this edge has been retouched, perhaps to establish a continuous ridge along the edge to direct the fracture path in order to insure a successful removal. Oriented with the bulbar end downward and with the original flake surface facing the viewer, the retouched edge is to the left on all three examples. Angles of the intersection of the ventral surface of the core and the flake facet are $1180,120^{\circ}$ and $121^{\circ}$. One specimen appears to have been thermally altered (reddish hue at bulbar end), but since the specimen is a surface find the thermal alteration is likely due to slash and burn clearing of the mound (Wilk 1976: 153). Length: $10.4 \mathrm{~cm}, 11.6 \mathrm{~cm}, 10.2 \mathrm{~cm}$; height: $3.7 \mathrm{~cm}, 3.7 \mathrm{~cm}, 3.3 \mathrm{~cm}$.

Category 2 ( $N=14$; Fig. 1$)$ : The largest group of "orange pee1" flakes was removed from artifacts that could have been repeatedly retouched by step flaking along the wider and convex end. The presumed working edges of the tools prior to retouch are steeply trimmed by step flaking and the edges are evenly convex. The edges clearly show dulling. The possible wear is not the kind expected if the specimens were tools used against hard materials. It is possible that the dulling is due to abrasive retouch rather than constituting actual wear. With the bulb of force oriented downward and the parent flake surface facing the viewer, the retouched edge is on the left on 13 examples and on the right on one. Four appear to have been thermally altered (one at the bulbar end). Edge angles vary from $85^{0}-121^{\circ}$. Dimensions: $7.0-12.4 \mathrm{~cm}$; he ight: $2.2-4.9 \mathrm{~cm}$.

Category 3 ( $\mathrm{N}=3$; Fig. 2, lower): These are tertiary flakes in that they represent at least the second in a series of "orange peel" flakes from their respective cores. Two exhibit the characteristic step retouched edges since the previous "orange peel" removal. Both are quite thin, show the characteristic dulling observed on many category 2 examples, and are slightly burned. The third example is more complex in that a removal was attempted from one side but failed. The failure was partially corrected by another removal from the opposite side. Apparently still not satisfied, but now having a continuous outer edge to guide the fracture, a third and successful removal was struck from the striking platform where the original removal was attempted. Edge angles are $170^{\circ}$, $107^{\circ}$, and $106^{\circ}$. Dimensions: $8.1 \mathrm{~cm}, 9.8 \mathrm{~cm}, 9.6 \mathrm{~cm}$; height: $3.2 \mathrm{~cm}$, $3.9 \mathrm{~cm}$, and $5.0 \mathrm{~cm}$.

Category $4(\mathrm{~N}=2)$ Fragments: One of these specimens is the distal end of an "orange peel". It would probably fit in the category 2 series had it been complete. It is broken at the proximal (bulbar) end by a thermal fracture. The second example is much more irregular in appearance than any other "orange peel" specimen. It, too, is the distal end, 

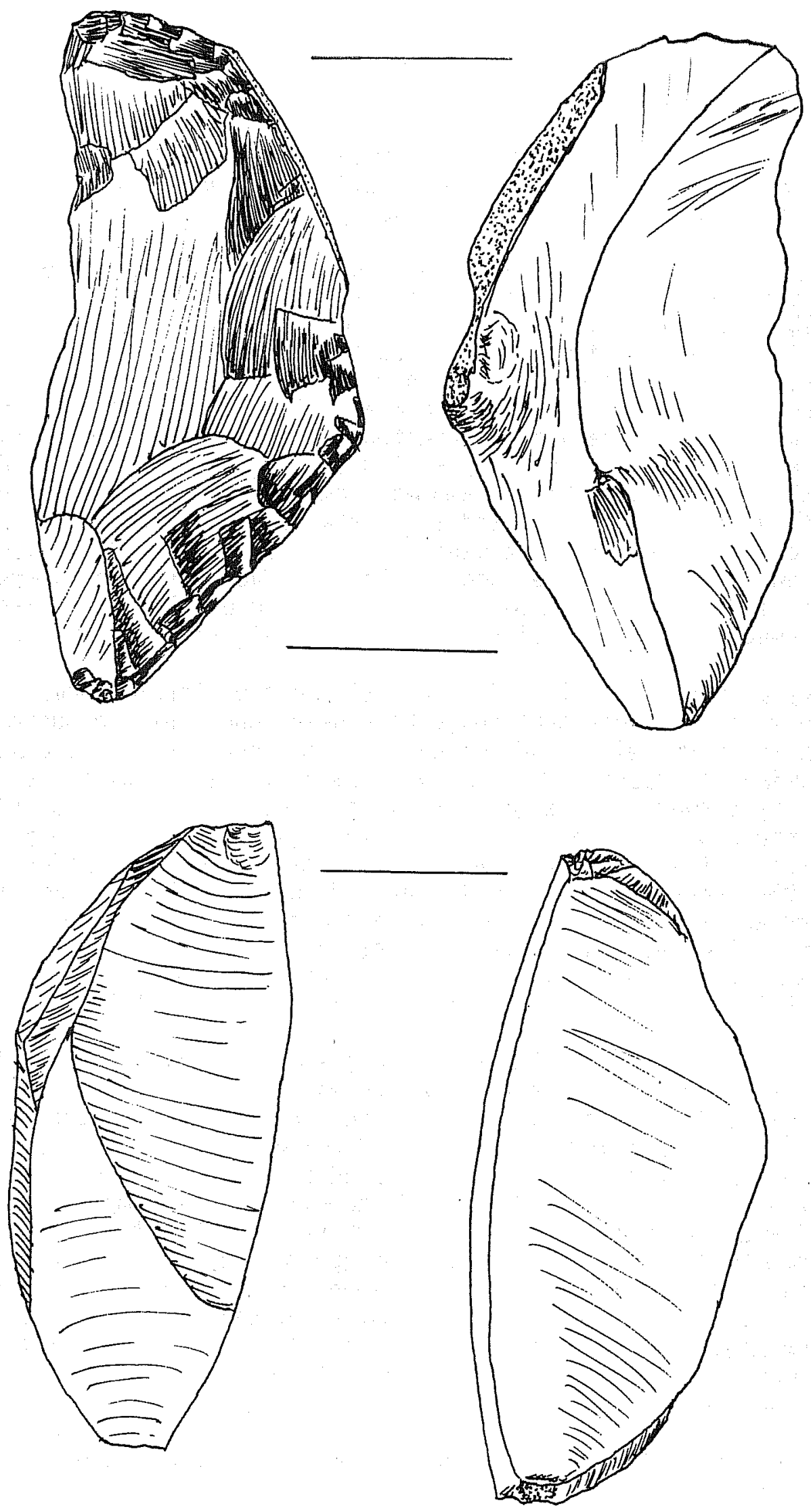

Figure 2. Category 1 and Category 3 "orange peel" flakes. Upper, Category 1 flake (both faces); Lower, Category 3 flake (both faces). 

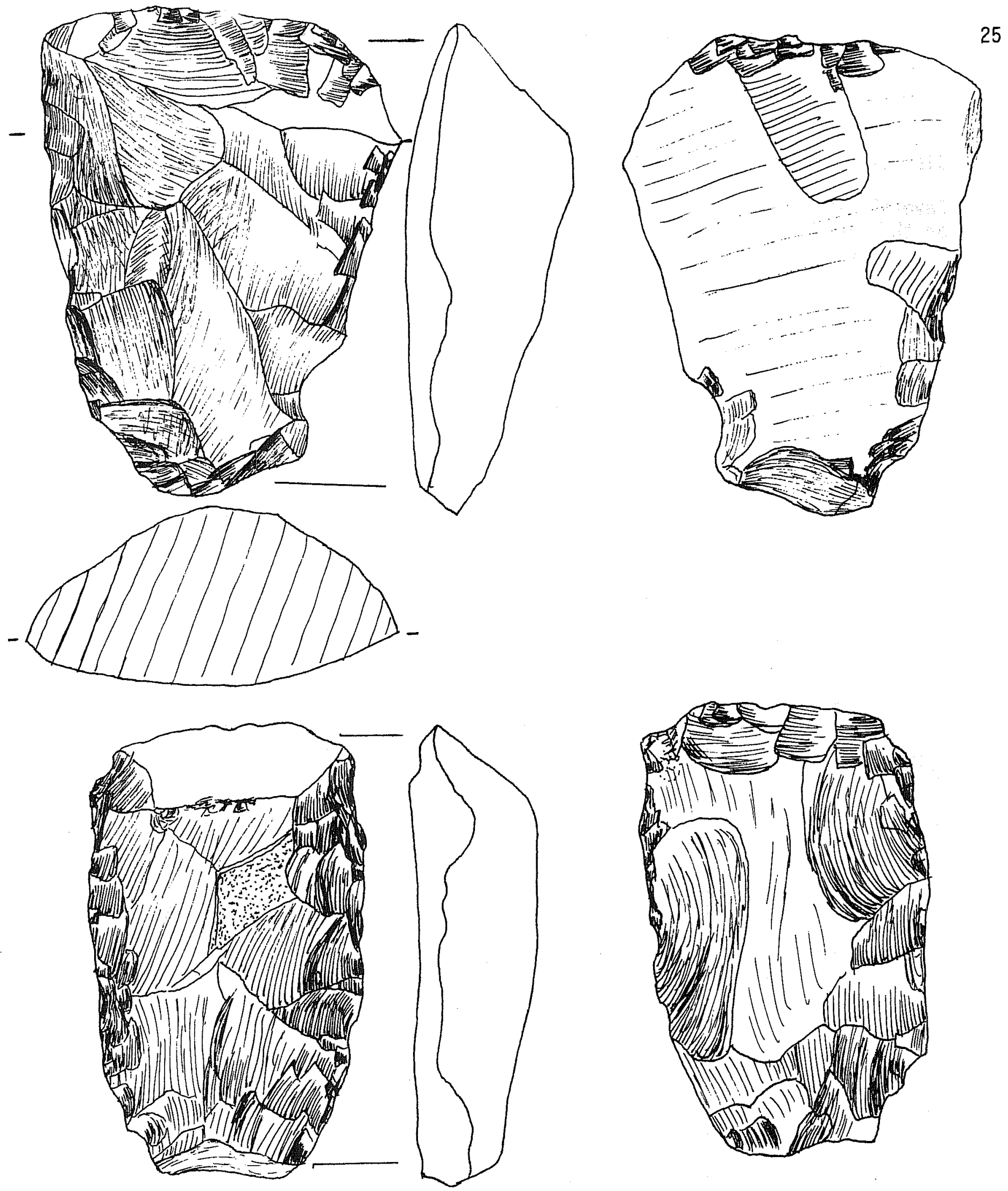

Figure 3. Passible cores for "orange peel" flakes. Adze-like tools exhibiting truncate retouch possibly resulting in "orange pee1" flakes. Upper, specimen No. C72.17 (both faces, transverse and longitudinal sections shown); Lower, specimen No. C66.5 (both faces and longitudinal section shown). 
having becr, snapped from the proximal end. Edge angles are $98^{\circ}$ and $119^{\circ}$.

Discussion of the "Orange Peel" Flakes

Several general observations are worthy of comment. The striking platform on the flakes, for example, was prepared by extensively dulling and blunting one corner--with one exception, the same corner--of the parent core. This point of detachment was the upper right hand corner of the hypothesized adze-like plano-convex tool with the convex surface facing the viewer and the wider end oriented upward (see Fig. 4 C). It may have been necessary for the flintknapper to straighten the retouched or working edge of the core in order to insure a successful removal, but this cannot be demonstrated with certainty on category 2 specimens. I suspect, however, that was the reason for the unifacial retouch on the category 1 specimens.

Curiously, there are no obvious eraillure scars (cf. Crabtree 1972:60) on the bulbar surfaces of any "orange pee1" flakes. This, and the slight lipping effect observed at the striking platform area of several specimens, suggest to me that hardwood mallets may have been used in their removal.

of the 22 specimens examined, the angle of removal--that angle created by the plane surface of the parent core and the facet created by the specimen's removal--varies from $85^{\circ}$ to $121^{\circ}$. The expected complementary angle on the core resulting from the "orange peel" flake removal would vary from about $60^{\circ}$ to $105^{\circ}$. Interestingly, this angle range does not differ significantly from that projected for the angle of the step retouched edge (i.e., $80^{\circ}-100^{\circ}$ ). Assuming that these are rejuvenation flakes, the rounded, dulled and slightly smoothed retouched edge may have been more of a factor necessitating rejuvenation than an angle increase through retouch of the edge angle itself.

Possible Cores for "Orange Peel" Retouch

Wilk (1976:166; Fig. 9.28) describes and illustrates a specimen which he believes to be a possible core for "orange peel" flakes. This specimen was included in the shipment of artifacts to The University of Texas at San Antonio and eventually to Texas A \& M University. The specimen is shown in Figure $5 \mathrm{~A}$. Close examination revealed that the curvate fracture across the wider end thought by Wilk to be the scar from an "orange peel" flake removal was instead a thermal fracture. The wider end on this specimen was burned and the flint exhibits numerous internal fractures and some discoloration due to thermal potlidding. The specimen was much too thin at the wider end to have yielded an "orange pee1" flake.

A search of the small sample of chipped stone artifacts accompanying the "orange peel" collection yielded four specimens of adze-like tools that appeared to have been retouched in a manner that would yield "orange pee 1"like flakes. These specimens are described individually.

C72.17: This is a trapezoidal-shaped unifacially chipped tool made on a 

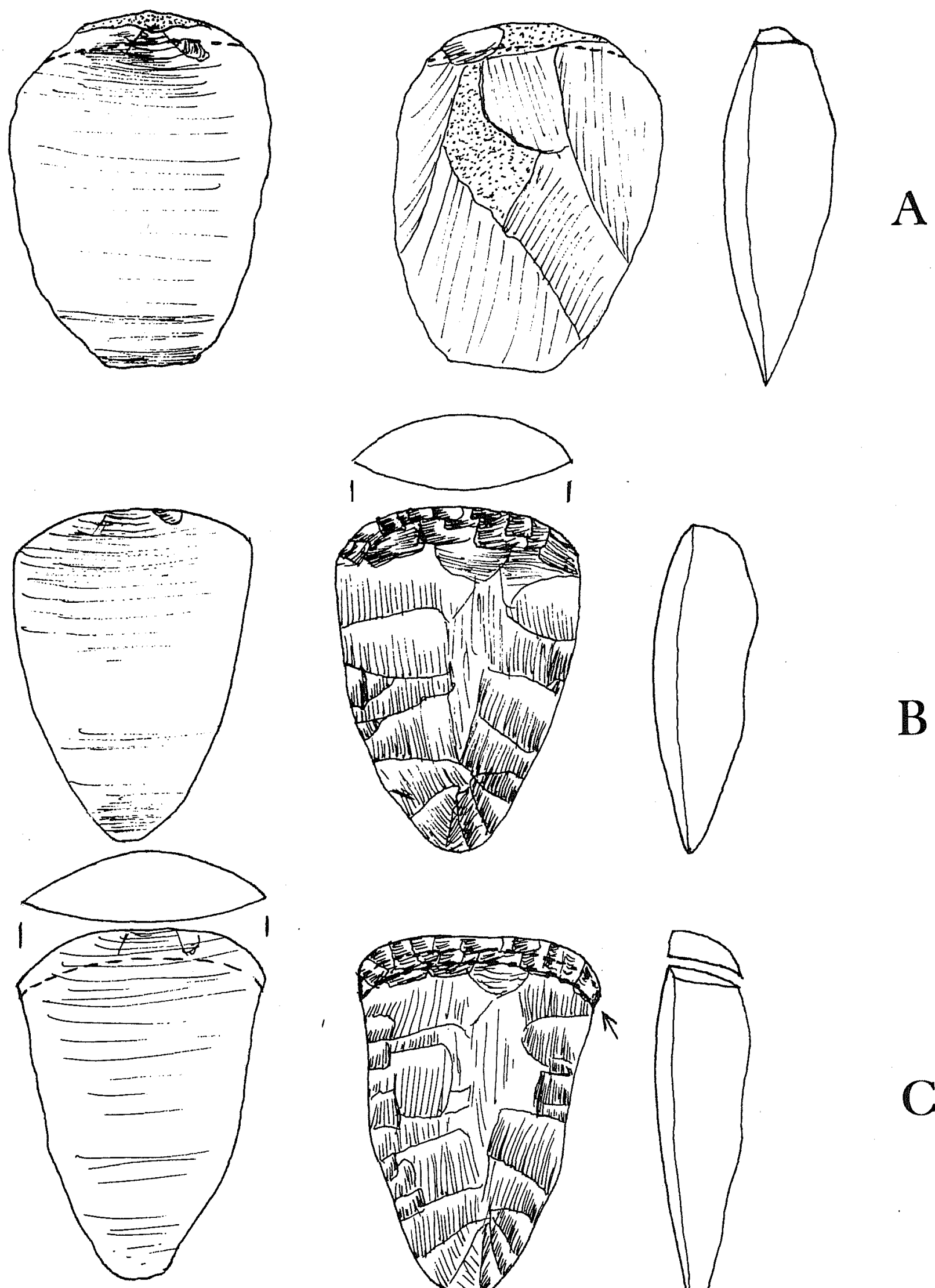

B
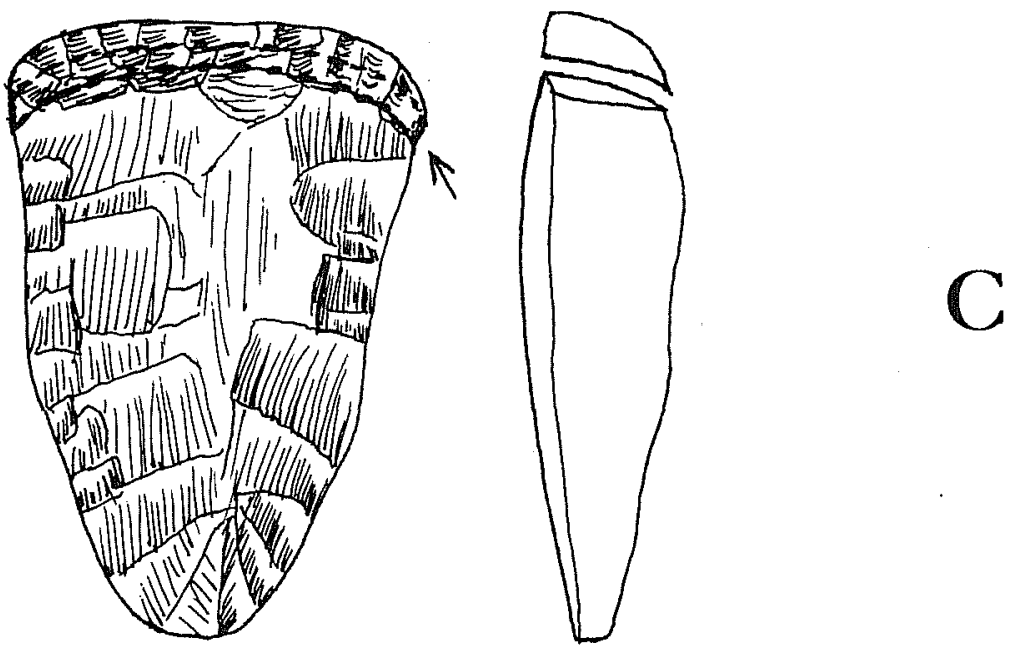

Figure 4. Hypothesized sequence for manufacture and retouch of adze-like tools illustrating how "orange peel" flakes may have been produced during the course of edge refurbishing. 
large, thici: flake (Fig. 3, top). It is described by Wilk (1976:168; Fig. 9.32) as an adze. The broader end exhibits traces of a single flake facet that removed the entire edge from corner to corner; edge angle created by this removal was $71^{\circ}$. The removal was struck from the right corner, the same corner which all but one of the "orange peel" were struck. The broader end has been mostly unifacially retouched with some minor bifacial retouching near the center on the ventral side. Dimensions: length, $9.2 \mathrm{~cm}$; width, $7.1 \mathrm{~cm}$; thickness, $3.4 \mathrm{~cm}$.

Comments: The size of the tool and character of the wider end plus subsequent alteration of this end suggests strongly that the beveled edge was created by a single flake removal; the resulting flake would have all of the characteristics of an "orange peel".

C82.2: This is a narrow, triangular-shaped artifact made from a large, thick flake which was shaped mostly by unifacial chipping. It is described by Wi1k (1976:168; Fig. 9.31) as a chise1. The wider end has been truncated by a single flake removal, again originating from the upper right corner (with the specimen oriented with the wider end up and the dorsal side of the parent flake facing the viewer). The angle created by the removal is $77^{\circ}$. The resulting edge is sharp and unretouched--and indeed appears to have been unmodified. The specimen may have been discarded subsequent to retouching. Length: $9.2 \mathrm{~cm}$; maximum width: $4.4 \mathrm{~cm}$; thickness: $2.9 \mathrm{~cm}$.

C66.5: This specimen is a subrectangular biface (Fig. 3, lower). It appears to have been fashioned from a large thick flake although it is difficult to ascertain this. Cross section is approximately planoconvex. One end is slightly wider and exhibits traces of a single truncated retouch flake having been removed from this end. The angle created by this removal is impossible to measure but is estimated to have been about $70^{\circ}$. Retouching of this and other edges was done mostly from the ventral or planar side. The specimen had undergone quite extensive retouch from both sides subsequent to the truncation. Length: $8.9 \mathrm{~cm}$; width: $5.2 \mathrm{~cm}$; thickness: $2.5 \mathrm{~cm}$.

Comment: The history of this particular specimen is clearly complex and later retouch and modification mask many of the earlier attributes. This factor should be taken into consideration in the search for possible cores of the "orange peel" flakes and signals the need to examine a sample of all the tool and debitage categories during the course of a technological analysis. The adze-like tools, whatever they were, may have been retouched in several ways during the time they were used. This specimen exhibits two possible ways: removing the entire edge with one stroke, resulting in an "orange peel" flake; and retouching the acute edge by removing flakes from the ventral (plane) side of the tool.

C80.4: This is another elongated thick plano-convex artifact that is mostly bifacially chipped. It appears to have been fashioned from a thick flake. The wider, thicker end exhibits several interesting flake removals. The first truncated the thicker end but created an irregular, recurved edge of approximately $90^{\circ}$. A possible attempt to straighten 
this edge resulted in the removal of a blade-like flake from the opposite edge. This flake made most of the edge obtuse (1150-1200). Another flake struck from the dorsal side removed the striking platform of the second flake and may have destroyed any hope of recovering from previous mistakes. The dorsal surface exhibits a medial ridge created by the termination of flakes originating at each lateral edge. The highest point of the ridge near the presumed proximal end evidences scars resulting from battering. This battering is subsequent to the apparent retouch attempts previously described. The purpose of the battering is unknown, but again demonstrates the complexities of reconstructing the life history of these artifacts. Length: $9.9 \mathrm{~cm}$; width: $5.5 \mathrm{~cm}$; thickness: $3.3 \mathrm{~cm}$.

Function of "Orange Peel" Flakes

Two hypotheses are proposed to explain the function of "orange peel" flakes. Hypothesis 1 is that the. "orange peel" flakes were the by-products of edge rejuvenation of adze-like tools. This hypothesis was based on the author's experience with a strikingly similar (albeit smaller) pattern of uniface retouch debitage in west central Texas (Shafer 1970). The second hypothesis, proposed by Wilk, is that the "orange peel" flakes were specialized tools. These hypotheses are discussed in detail below.

The first hypothesis can best be presented by describing a reduction sequence for the "orange peel" flake cores based on the observations of various attributes in the sample. This sequence, illustrated in Figure 4 , is as follows. A large, thick flake was selected (Fig. 4 A). The butbar end was designated as the use end of the anticipated tool in order to take advantage of the curvature of the ventral flake surface due to the swollen bulb of force. The remainder of the flake was trimmed to an elongated triangular shape (Fig. 4 B). The bulbar end was either unifacially retouched to a steep, convex edge for use or the striking platform remnant was removed in one blow usually struck from the right corner of the wider end (ventral side up). This single removal created an "orange peel" flake containing traces of the striking platform and bulb of force on the trimmed edge (Fig. $4 \mathrm{C}$ ). As the adze tools were used and perhaps retouched through step flaking, eventualiy edge wear and perhaps resin accumulation along the step fractures necessitated refurbishing. The rounded edge may have become too stepped or obtuse for additional step retouch that in order to continue using the tools, complete removal of the edges was necessary. The process of removal was accomplished by roughening one corner of the tool in preparation of a striking platform and, using the retouched edge to guide the fracture path, removing the entire edge with one blow. The technique is essentially that of blade production modified to produce a new working edge with an angle of approximately $60^{\circ}-800$. Critical to insure successful removal was achieving an even curvature of the retouched edge. This curvature was the surface or ridge that directed the fracture path.

Since the production and rejuvenation of the adze-like tools is one of reduction, mistakes can be expected at every step and exhausted examples should fossilize each critical step in the manufacturing sequence. Despite 
the small sample, a model of virtually the entire sequence can be constructed. That the convex, retouched edge of the "orange pee1" flakes originated from the bulbar end of large flakes is certain. Category 1 "orange peel" flakes may represent initial edge shaping for unifacial adze-like tools by removing the striking platform and creating a suitable working edge in a single removal. Category 2 flakes may represent the by-products of rejuvenating tools repaired or retouched by step flaking during the process of use. Two of the category 3 flakes may represent retouch debitage from tools that had previously been rejuvenated via the "orange peel" technique, retouched by stepped flaking, became dull through use, and retouched again by the "orange peel" technique. Three plano-convex adze-like tools exhibit traces of truncations across the wider end and the angle of this retouch conforms to the expected complementary angle of the "orange peel" flakes. Weighing the evidence in the small sample that agrees with the proposed reduction sequence of adze-1ike tools certainiy provides a strong basis for the hypothesis that the "orange peel" flakes are uniface retouch debitage.

\section{TESTING HYPOTHESIS 1}

I anticipated having the opportunity to visit Colha and to examine several of the debitage mounds known to be present. The opportunity to collect selected artifacts from certain areas, however, was not anticipated and made possible a much more thorough analysis of the field collected sample. Collecting was indeed selective and most debitage specimens were collected from a bulldozed refuse mound southeast of Masson's house near the public road. The artifacts selected for collecting were those that represent either stages in adze manufacture or variations in "orange peel "flakes. Numerous examples of completed and exhausted adzes were seen in and near the ceremonial center and examples of these were collected. The initial intention was to use the artifacts as visual aids in the presentation of my paper on adze manufacture at the evening symposium at Orange Walk Town. The field collected sample caused me to rethink certain aspects of the adze manufacture and retouch sequence. In short, the original hypothes is was not al together confirmed by the new data. Based on field examination of a massive quantity of debitage and a large sample of tools at Colha, I am currently of the opinion that the "orange peel" flakes are indeed debitage of adze manufacture but that the rejuvenation portion of the original hypothesis is in error. Figure 5 B-D illustrates three artifacts representing examples of steps in what I hypothesize the adze manufacturing sequence to be. In essence, this sequence can be described as follows:

1. A large flake was removed from a prepared core (Fig. 6 A). This flake was relatively thin in proportion to width and length and was longer (along the flake axis) than it was wide. A number of very large flakes which could have served as adze blanks were seen in several areas of Colha. One was collected and passed around at the symposium.

2. The striking platform of the large flake was retouched unifacially to form an even convex edge and the lateral edges were trimmed to shape the specimen to a rough, triangular outline (Fig. 6 B). 


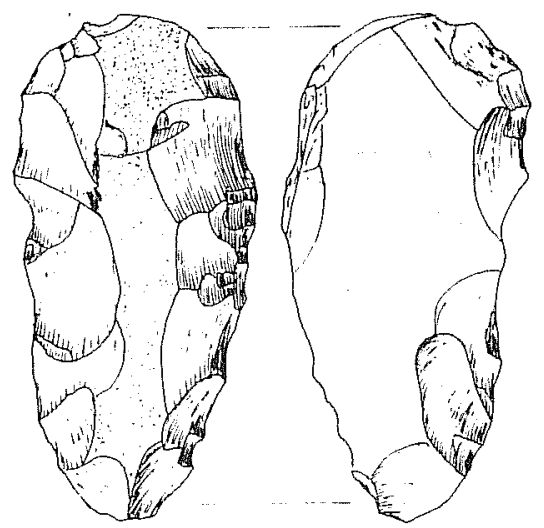

A
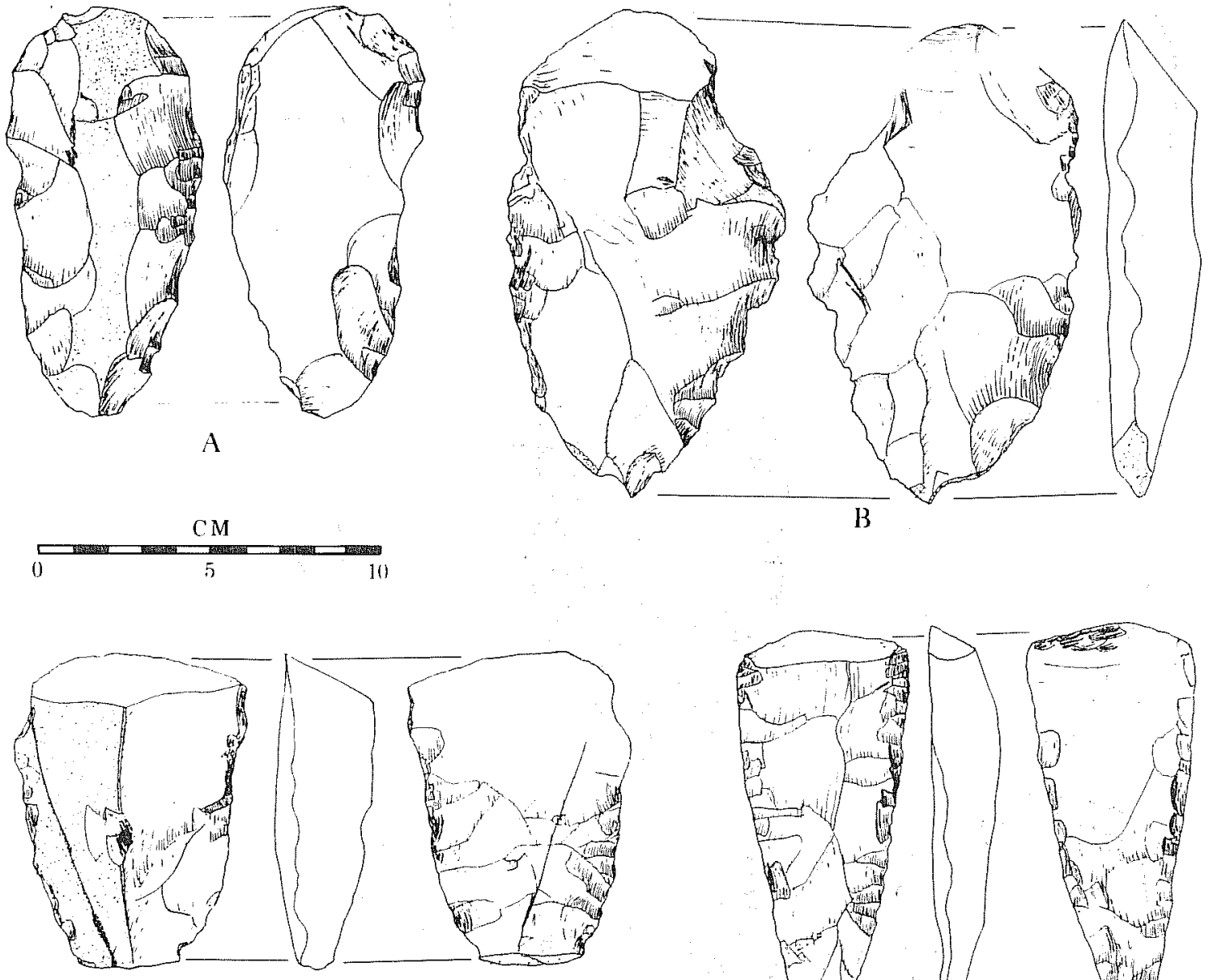

C
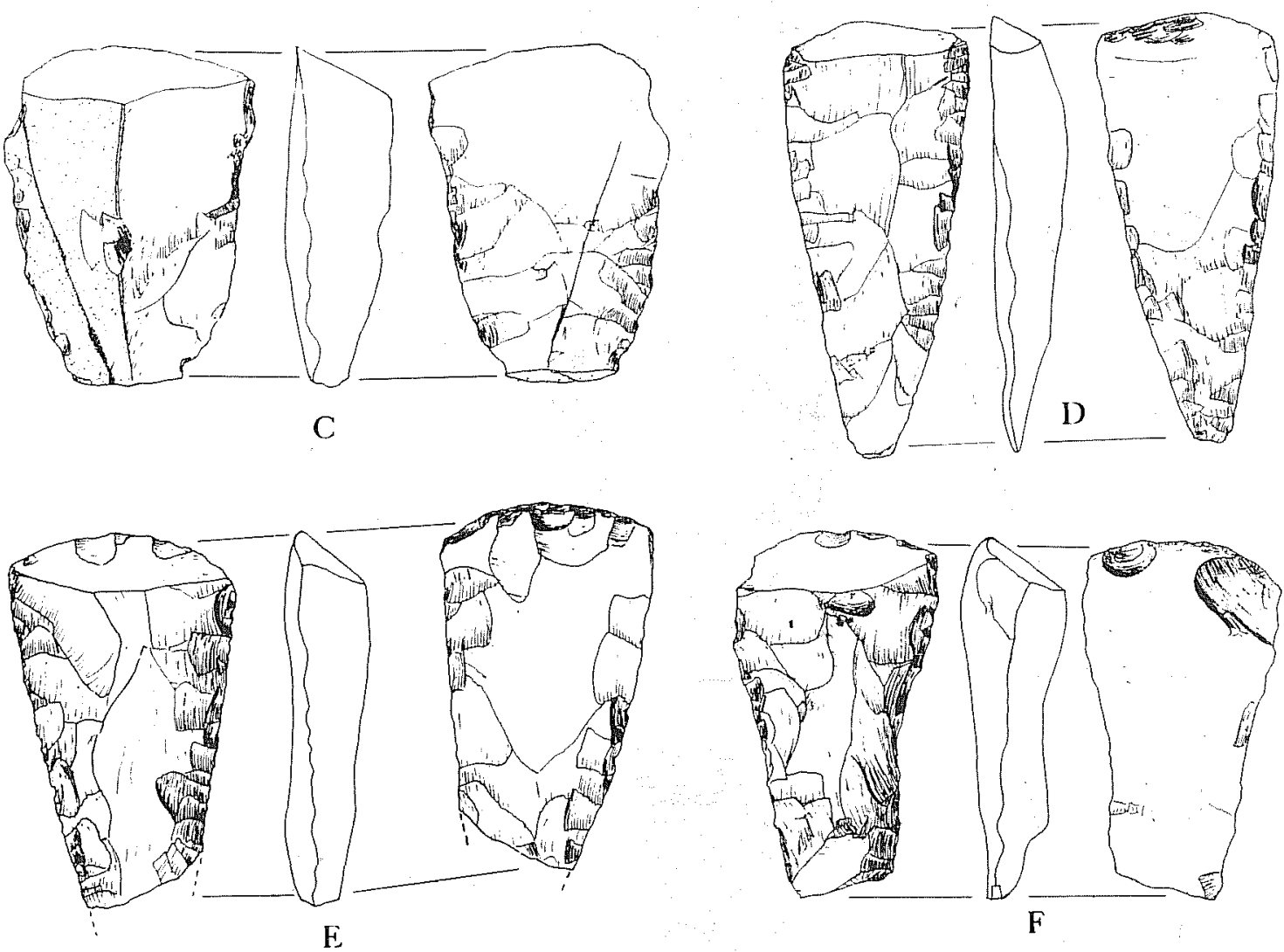

Figure 5. Artifacts from Colha. A, biface reported by wilk as being possible "orange peel" core; $B$, rejected adze-preform after removal of "orange pee1" flake; $C$, adze-preform; (,$C$ from bulldozed refuse mound); D-F, adzes co Tlected from ceremonial center. 

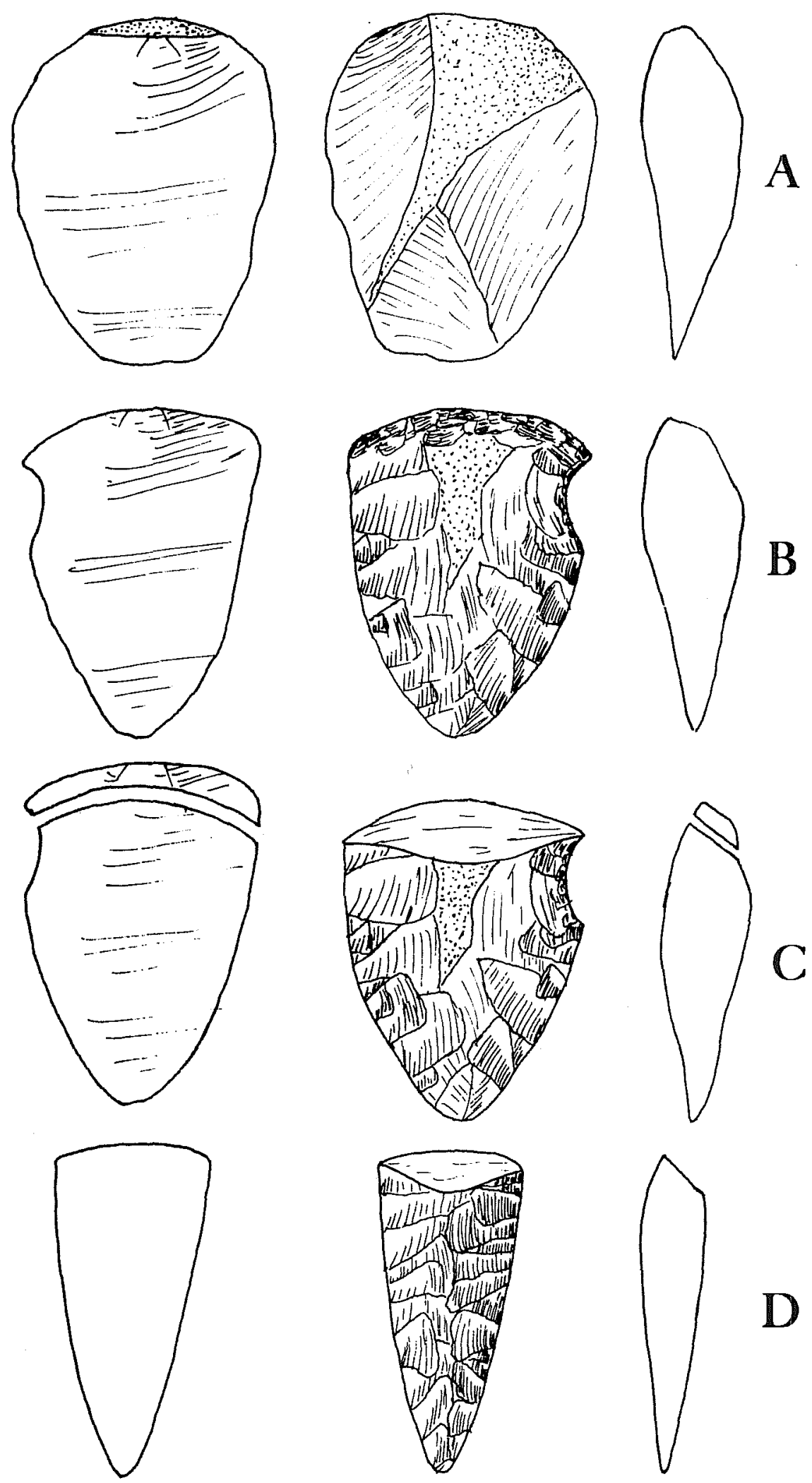

Figure 6. Revised hypothesis for the sequence of adze manufacture. "Orange peel" flakes are the result of creating the truncate bit on the adze preform. 
3. A broad notch (Fig. 5 B; Fig. 6 B) was prepared in one edge near the wider end. Orienting the specimen with the dorsal side facing the viewer and with the wider end placed upward, this notch is usually located in the upper right-hand corner. A striking platform was prepared on the corner of the notch with the intersecting convex edge. The first (and if successful, the on Ty) "orange peel" flake was then removed, possibly with a soft hammer (but a hammer with considerable mass nonetheless), for the purpose of creating the edge angle and bit of the adze (Fig. 6 C).

4. The adze preform was then bifaced and thinned to the desired size and form (Fig. $5 \mathrm{D}, \mathrm{E}$; Fig. $6 \mathrm{D}$ ). Debitage from the thinning process would include biface thinning flakes and preform failures due to thinning errors. Mistakes during the removal of "orange peel" flakes also occurred (Fig. $5 \mathrm{C}$ ) and these are manifested on both the flakes and cores. It should be pointed out that "orange peel" flakes will always be longer than the adzes are wide, due to subsequent reduction of the adze preform through final shaping. The later retouch often masks or removes negative features of "orange peel" flake scars. This, plus the fact that I could not find tools large enough to serve as retouched tools, finally led me to favor the notion that the "orange peel" flakes were produced during the initial step of adze manufacture rather than being a product of adze bit rejuvenation as proposed in the first hypothesis. And my continued reference to the tools as adzes is based on an inspection of numerous tools found lying in and around the ceremonial center at Colha. I collected one of these tools which showed an especially good example of wear. This specimen is shown in Figure $5 \mathrm{~F}$ along with other examples of adzes and adze failures (Fig. 5 B-E).

\section{TESTING HYPOTHESIS 2}

The second hypothes is is that the "orange peel" flakes were some kind of specialized tool as Wilk first assumed. The patterned production of the flakes, their apparent abundance at Structure 100, plus the curious shape and combination of attributes would indeed create suspicion that they were specialized tools. Two observations by Wilk, however, tend to weigh heavily against this hypothesis. First, he noted that most "orange pee1" flakes were complete whereas other tools were mostly fragmentary. Second, only one possible candidate for an "orange peel" flake core was observed by him and this specimen has since been rejected as a possible core. If the items were used as tools which resulted in the extensive step fracturing, their delicacy could doubtfully withstand prolonged wear without breaking. Second, the opposite edge is indeed sharp and is usually unaltered. Also, my observation that four plano-convex tools in the initial study collection were retouched in a manner that would create flakes similar to "orange peels" indicates that such items could result fortuitous $7 y$ through systematic and patterned retouch. In short, I reject the second hypothesis on several grounds, but mainly because their attributes are best explained by the reduction sequence model and because their common occurrence and complete condition are more likely due to the fact that much manufacturing activity was conducted at Structure 100 and the flakes are by-products of tool production activities of specialists. The seeming paucity of cores could be due to skill of the artisans or to the difficulty 
in recognizing the cores. My own feeling is that by placing attention on the truncating technique, "orange pee1" flake cores will become more apparent and more easily recognized.

The refined model of adze manufacture and "orange peel" flake production has been presented. The debitage at Colha is enormous in quantity and the lithic specialization includes a broad range of tools. One technique of adze bit formation has been described and is based on the inspection of debitage, failures and end products. Because we know so little of the Colha lithic technology at this time, it would be naive to claim that the "orange peel" question has been resolved. Indeed, a technique so expedient as the "orange peel" or truncating method would have been used to either prepare working edges or ends to other specialized tools as well as a technique for edge rejuvenation which we have not yet recognized. In short, the "orange peel" flake method is one specialized technique used by the Mayan flintknappers at Colha; undoubtedly there are others, but these will become clear only after an intensive analysis of debitage and tools is carried out.

\section{REFERENCES CITED}

Crabtree, D. E.

1972 An Introduction to Flintworking. Occasional Papers of the Idaho State University Museum 28.

Shafer, H. J.

1970 Notes on Uniface Retouch Technology. American Antiquity $35(4): 480-487$.

Wilk, R.

1976 Superficial Examination of Structure 100, CoTha. In: Archaeology in Northern Belize. British Museum-Cambridge University Corozal Project 1974-75 Interim Report:152-173. Cambridge. 
WORK IN PROGRESS AT COLHA, BELIZE, 1976

Richard WiTk

Northern Belize is an area rich in archaeological resources, in which the Corozal Project has often found its efforts spread very thinly. The investigations at Colha have so far been managed as a small segment of the Corozal Project's general program in the Corozal and Orange WaTk Districts, and thus the site has received much less attention than it deserves.

Colha is located on the farm of John and Herbert Masson, just north of the Orange Walk District's southern boundary (see Fig. 1). There is a minor ceremonial center, surrounded by many square kilometers (mostiy unmapped and under forest cover) of house mounds and piles of chert artifacts and debitage which we have called workshops.

An effort was made this season to estimate the total area of the site by foot survey and the use of air photos. The eastern and western site boundaries are evident where the Northern Highway crosses them, but the other limits to the site are covered by thick bush, and are crossed only by a few trails. Along the highway the site stretches between 2.5 and 3 $\mathrm{km}$; to the south dense mound concentrations are still encountered more than $1.5 \mathrm{~km}$ from the road, and may continue for more than another kilometer. To the north the site extends more than $2 \mathrm{~km}$ from the road and may continue to the edges of a large swamp, more than $3 \mathrm{~km}$ north of the road. A minimum site area is therefore $8.75 \mathrm{~km}^{2}$; extrapolating from the areas already mapped, in which mound densities average to about 460 per $\mathrm{km}^{2}$ (excluding the ceremonial center), the minimum number of structures present at the site is approximately 4,000 .

It is worth pointing out that a density of 460 structures per $\mathrm{km}^{2}$ is more than double the figure of 197 structures per $\mathrm{km}^{2}$ given by Puleston for the combined residential areas of Tikal and laxactun (again excluding the ceremonial centers; Puleston 1974:308). On this basis alone, colha is clearly an exceptional Maya site.

My first season at Colha was an al1-too-short two weeks in the spring of 1973. Given the complexity and size of the site, an extensive survey program was ruled out, and excavations were limited to a single trench in a particularly enigmatic feature which turned out to be a chert-paved sacbe (reported in the Corozal Project 1973 interim report). The rest of my time was devoted to the intensive investigation of a single workshop mound, Structure 100 (Wilk 1976). Despite the problems of generalizing about other workshops on the basis of a single example, my work provided information on both technical problems of archaeology at Colha and the kinds of artifacts which were being produced at a single workshop.

Structure 100 was chosen because of accessibility and an apparent lack of any serious disturbance. I mapped all tools, took debitage samples, and attempted both distributional and technological analys is of the artifacts. Some of the artifacts have since been restudied by T. R. Hester and H. J. Shafer. (see Shafer's paper in this volume) from a more strictly 


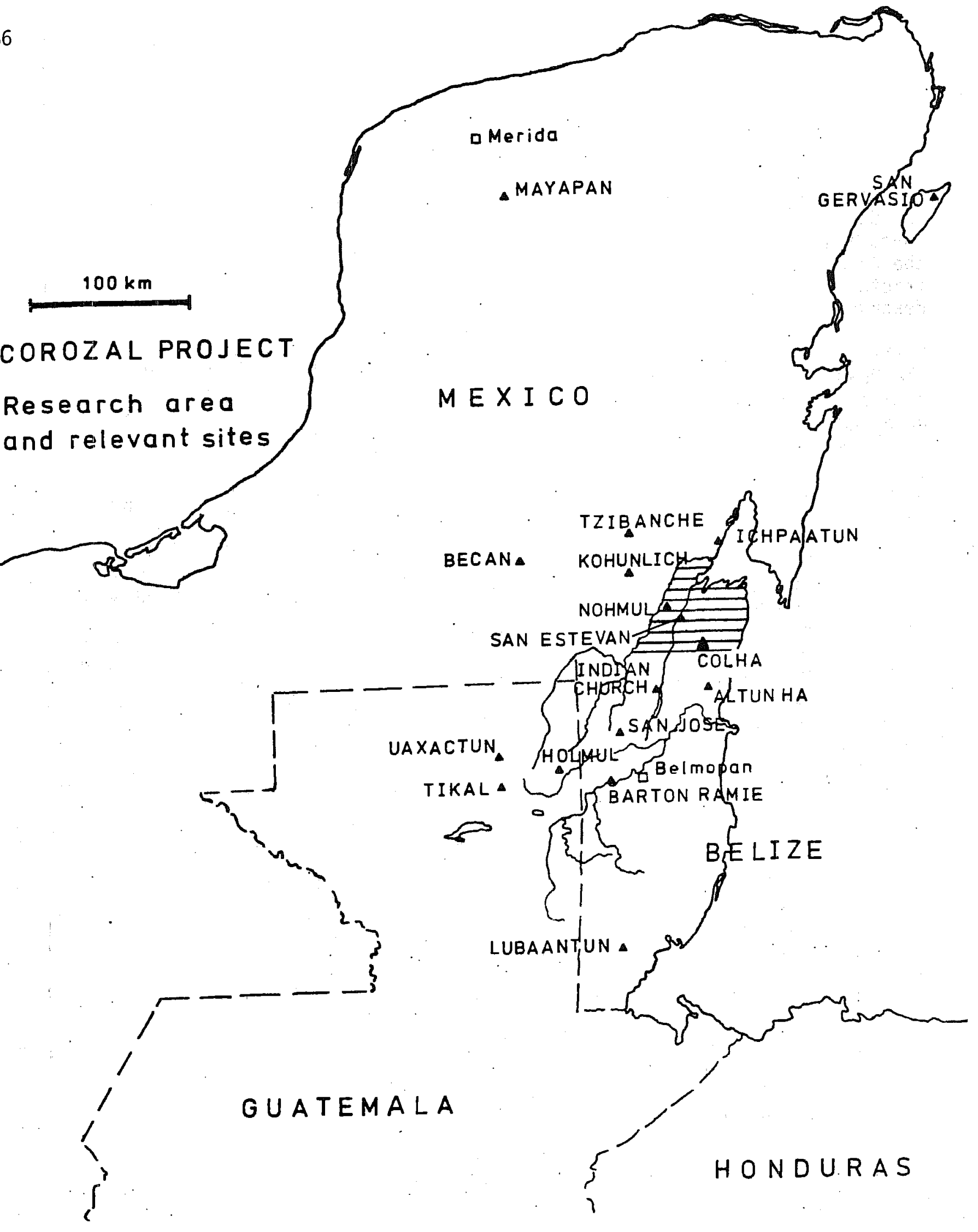

Figure 1. Location of Colha, Belize. The location of the site of Colha is shown in the shaded area of northern Belize. 
technological point of view. Two very basic problems remain; delimiting the chronology of the workshops at the site, and determining the way in which production at Colha was organized.

Duncan Pring returned to Colha in 1975 and spent several weeks excavating within the ceremonial center. Though his work was mostly oriented towards ceramic chronology, several layers of workshop debris were excavated and sent back to England, to join the rest of the Corozal Project 1ithics, out of this investigator's present reach.

The ceramic sequence at Colha extends a 71 the way from the Middle Preclassic to the Late Postclassic, some 2400 years (Pring 1976), though the excavated Tithic debris dates to Late Classic and Postclassic times. Previous typological analysis of Colha material in the Masson collection has shown considerable similarities to the Postclassic lithics at Mayapan in Yucatan, and the Late Classic lithics from other sites in Belize, such as Nohmul, Barton Ramie and San Jose. An earlier dating for large scale lithic manufacture at Colha cannot be ruled out; the Corozal Project excavations in Early Preclassic levels at the site of Cuello turned up many artifacts which show similarities to Colha surface finds. In 1976, attention will be paid to ceramic remains from workshops, in an attempt to further clarify chronological problems, though excavation of workshops would be the ideal method.

The technical problems of excavating a deposit of solid artifacts and debitage are formidable. Hundreds or even thousands of kilograms of chert would have to be washed, sorted, counted and analyzed from just a single meter square test pit. Laboratory facilities on site would be an obvious necessity; specialized excavation and recording methods will also have to be developed.

Such an ambitious undertaking is beyond the limited available resources during 1976. The Masson family, with its characteristic generosity, has offered to provide accommodations and a pack horse for collecting artifacts; we will also have the Corozal Project survey and excavation equipment available. In addition, Texas A \& M University has kindly provided funds for the shipping of artifacts back to the United States for analysis, under a permit provided by the Belizean government.

Given the vast size of the site, and our limited resources, a specific sampling strategy promises the largest possible information return. Though operations at Structure 100 disclosed a surprising variety of artifacts and production processes in a very small area, we have as yet no idea of the range of variability between workshops at the site. Are there patterns of organization at the site which are larger than the individual structure unit? This question has a wider relevance for Maya studies because it reflects upon the presently controversial nature of ancient Mayan social, political and economic organization? Various models are at hand which portray Classic Maya society as complex, hierarchical and based on specialized production and distribution of products, as opposed to the older theocratic state models which tended to stress religion and art at the expense of trade, politics and welfare. An important piece of ammunition in the hands of proponents of secular models is the increasing amount of evidence which suggests considerable 
occupational specialization during the Late Classic, at least in the large ceremonial centers of the "core" zone. Marsha 11 Becker's (ms.) work at Tikal has suggested to many that Classic centers had quite deve1oped structures of complex craft specialization, perhaps on a clan basis, involved in a complex redistributive economy. Colha is not in the central Peten, nor is it a large ceremonial center; yet it seems to show the existence of an entire site with a single speciality-evidence that commercial structures existed at a much higher level than is presently accepted on the basis of intra-site evidence for specialization.

The tracing of the trade networks which distributed Colha artifacts will be a long and complex study. Neutron activation analysis of chert may be a necessity. But before the Colha workshops are fitted into a larger political and commercial network, we must have an accurate picture of how production within the site was organized; hopefully, this will be disclosed by distributional analysis.

Actual tactics in 1976 will be a variation of those used on Structure 100: extensive surface collection of artifacts and intensive localized sampling of debitage and debris. Operations will be limited to those mounds presently mapped which are clear of vegetation and have not been bulldozed by the Public Works Department. Two hundred fifty acres of land to the south of the creek have been cleared and burned this season, revealing several hundred new, unmapped mounds which we will not be able to get to in 1976.

Within our target population of 186 cleared, mapped structures (the ceremonial center has been excluded) there are enough gross morphological differences to allow stratification into three "types". First, there are earthen mounds which contain little flint debris or artifacts, much like the common house mounds at other sites in northern Belize. Then there is a large number (more than half the total) of mounds which consist mostly of flint nodules and limestone rubble, usually with a few artifacts scattered on the surface. The nature and function of these structures is still unknown, though it is unlikely that they are workshops considering the general lack of chipping debris or hammerstones. Finally is the group of structures, 1ike Structure 100 (comprising about $13 \%$ of the total structures in the mapped area), which are largely covered with fine chipping debris, broken and discarded artifacts in al1 stages of manufacture, and large numbers of chert cores and nodules. Examination of bu11dozer cuts and tree falls shows that these mounds are solid debris and artifacts rather than earthen platforms covered with sheet deposit. A variant of this kind of workshop is the eight large areas near the ceremonial center, where the artifacts and chipping debris are extensive, thin layers on the surface rather than piled up mounds. The fact that al1 three types of mound occur in close proximity to each other is a strong argument that the differences are due to more than differential erosion or preservation.

The first stage, just completed, involves the plotting of each type of mound on a master plan of the site, following intensive surface examination. Each stratum will now be random sampled; the sample size determined 
by the limited amount of money available for shipping. Two by three meter squares will be laid out on each mound selected for sampling, and all artifacts enclosed, including preforms but excluding cores and debitage, will be collected. The location of the test squares will be determined by choosing the clearest and most easily collected area, rather than by any specifically randomized procedure.

One debitage sample will be taken from each mound from a $25 \mathrm{~cm}$ square located at random on the surface. This material is most important for efforts to reconstruct technological processes of tool production at each workshop.

Analys is will be carried out at the University of Arizona with the guidance of Dr. Arthur Jelinek. Artifacts will be sorted morphologically, as will the debitage, and the results will be coded for use with the University of Arizona CDC computer system, with the computer time provided by the Anthropology Department. Attention will be paid to the technological attributes of the artifacts and debitage in order to draw up more complete flow diagrams of the artifact reduction sequence than that proposed on the basis of the Structure 100 material (Wilk 1976: Fig. 9.34).

The general objective of the analysis of workshop artifacts is a set of statistics which describes the variability of the data in terms of indices of homogeneity and heterogeneity. A program for this has been developed at the University of Arizona, and has been used for the analysis of pottery distributions on Cozumel Island (Gordon Bronitsky, personal communication). There are three possible outcomes which would have clear implications for interpreting the productive organization of the site:

(1) High variability in the composition and output of workshop mounds with no significant clustering, a situation suggesting a large number of individual workshops conducting different operations or combinations of operations, with 1 ittle centra 7 - control or organization. An alternate explanation, verifiable only by excavation, would be that the surface remains sampled were mixed deposits from several phases, obscuring any meaningful variability.

(2) High variability between mounds with significant clustering, which I will call polytypism. The nature of the clusters would be the key to interpretation; they may have spatial correlates or temporal correlates, and will provide data for further stratification of the sample when test excavations become practical. If specific workshops tend to produce specific products or clusters of products, a degree of intra-site organization or control is implied. It is also hoped that significant clusters of artifact types will emerge, allowing the identification of tool kits and perhaps shedding light on the functions of some artifacts by association.

(3) A third outcome, that there is little variability between workshops, is very unlikely to occur. Preliminary observations show that there is a wealth of variation at the site. 
Whatever the conclusions of the above analysis, it will provide a useful guide for further work at the site. A 1arge, well-staffed program of mapping, geological survey, controlled surface sampling and excavation is the on1y way of approaching such a unique and important area. The work done in 1976 has been designed as a guide for this future research; it will provide the data necessary for coherent, large-scale work by allowing a further stratification of the mound population so that the test excavations will produce maximum data return. At the same time the program should produce data of more general interest to lithic specialists and Maya archaeologists.

\section{ACKNOWLEDGEMENTS}

I would like to acknowledge the interesting discussion of the field symposium participants, particularly for stimulating me to think more carefully about my work. I hope some of the members can return to Colha in the future to share the fascination of the site with me. Thanks are also due to the Masson family, protectors of the site, gifted "bush archaeologists" and providers of endless hospitality, as well as a good argument now and then.

\section{REFERENCES CITED}

Becker, M. J.

ms. Indications of Social Class Differences Based on the Archaeological Evidence for Occupational Specialization Among the Classic Maya at Tikal. Manuscript on file, Westchester State College.

Pring, D. R.

1976 Excavation Summaries, Colha, 1975. In: Archaeology in Northern Belize. British Museum - Cambridge University Corozal Project 1974-1975 Interim Report:174-183. Cambridge.

Puleston, D. E.

1974 Intersite Areas in the Vicinity of Tikal and Uaxactun. In: Mesoamerican Archaeology, New Approaches (N. Hammond, ed.): 303-313. University of Texas Press, Austin.

WiTk, R.

1976 Superficial Examination of Structure 100, Colha. In: Archaeology in Northern Belize. British Museum - Cambridge University Corozal Project, 1974-75 Interim Report: 152-173. Cambridge. 
PRE-COLUMBIAN MAYA DEVELOPMENT OF UTILITARIAN LITHIC INDUSTRIES:

THE BROAD PERSPECTIVE FROM YUCATAN

Irwin Rovner

INTRODUCTION

The major 1 ithic assemblages used in this study were obtained from excavations conducted by the Middle American Research Institute, Tulane University, at the northern Yucatan site of Dzibilchaltun and at the central lowlands sites of Becan and Chicanna in the Rio Bec. In both cases lithic phase assemblages were defined providing a sequence extending from Preclassic through the Postclassic periods. Comparison of these sequences yielded some similarity in their patterns of development as we11 as several significant differences due in part to marked differences in locally available lithic resources. This condition is typical of the entire Maya lowlands; namely, that no particular locality possessed the full range of 1 ithic resources to fill completely their basic utilitarian needs through time, much less their ceremonial requirements.

Dzibilchaltun on the north coast of Yucatan, was almost totally devoid of good quality local 1ithic resources. Usable chert is not present and even the limestone of the area is of such a coarse, porous quality that the residents of Dzibilchaltun also engaged in importing utilitarian limestone implements during much of their history. The most common chert at Dzibilchaltun is a hazy gray-brown. The abundance of this chert at nearby Mayapan suggests that the source for this material is relatively close, possibly in or near the Puuc Hills which could have also supplied a better quality limestone to Dzibilchaltun. The central and southern lowlands shared similar lithic resources, good quality limestone and a mediocre quality grayish-white chert common to wide areas of the Peten, Rio Bec and Belize. This chert was used for a variety of common biface core tools-celts, picks, choppers, etc.,--found at sites in all three areas. Some moderately good quality chert cobbles were also available ranging in color from pinkish gray to yellowish brown. However, the high quality fine brown chert favored for Tepeu phase projectile points is rare to the point of essentially being absent in Yucatan, as are granite, basalt and obsidian. These resources were available variously from sources in Belize or the volcanic highland zones. In sum, lithic resource distribution clearly departs from the often-stated characterization of the Maya lowlands as "environmentally uniform". On the contrary, 1ithic resources which were basic to Maya economy and technology at the utilitarian level were quite diverse and divergent establishing many access gradients amenable to 1ocal industrial specialization, development of trade networks and competition for resources.

\section{INDUSTRIAL DEVELOPMENT OF THE LATE PRECLASSIC}

The Dzibilchaltun and Rio Bec Preclassic assemblages like many other Maya 
Preclassic 1ithic assemblages show three diagnostic characteristics: (1) they are overwhelmingly reliant on local resources; (2) show no significant development of short distance exchange networks to exploit lithic resource diversity; and (3) an inexplicable, but clearly evident, absence of stone projectile points. These features existed over a broad area as indicated by reports of various Early to Late Preclassic 1 ithic assemblages from Chiapa de Corzo, Chiapas (Lee 1969); La Victoria (Coe 1961) and Salinas La Blanca (Coe and Flannery 1967), Guatemala; Uaxactun (Rickertson and Rickertson 1937) and Altar de Sacrificios (Willey 1972) in the Peten; and Barton Ramie (Willey et al. 1965) and San Jose (Thompson 1939) in Belize. At Kaminaljuyu Shook and Kidder (1952) are quite explicjt in stating that their excavations in Preclassic Miraflores phase deposits fajled to produce a single projectile point in spite of the presence of a clearly well-developed obsidian industry.

The Late Preclassic assemblage from the Rio Bec consists entirely of locally available material with the exception of a sparse presence of imported obsidian. Ground stone implements were also sparse, most probably a result of collection bias in the field, and are non-descript domestic implements. A substantial chert industry is represented by two general, related classes of implements--bifacial core tools, mostly celts, and a variety of simple, unifacially modified flake tools. These flake tools have been classed variously as simple retouched flakes, gravers, beaks, denticulates, and notches. Both cortex (decortication) flakes and percussion trimming flakes, probably no more than the by-products of biface celt manufacture, were selected without any apparent preference. These flake implements show no morphological characteristics to distinguish them from similar implements commonly found in other lithic phase assemblages.

The biface celts, while showing clear and significant morphological variation through time, are present throughout the Rio Bec sequence. These celts, along with the associated flake tools, represent a basic local 1ithic industrial tradition which the Rio Bec shared with similar local industries to the south and east. Biface celts are rare in the Dzibilchaltun collections appearing late in the sequence suggesting that the function of the biface celt was ecologically related; $j . e .$, useful in the tropical forest of the Rio Bec and Peten, but not in the scrubland-chaparral of the north coast. Morphological variation in biface celt assemblages through time show several potentially significant features. The Preclassic celt assemblages show the least standardization of quality of manufacturing technique, techniques employed and range of morphological variation. Poorly executed, thick and asymmetric celts are characteristic, indeed, possibly diagnostic of the Preclassic assemblage. If they were merely rejects, they should be expected to occur with celts and celt manufacturing debitage common in later phase assemblages. However, they are virtually absent in every phase assemblage of Tzakol 3-equivalent age and later. An informal test of this was conducted in survey collections from several sites in the Rio Bec area south of Becan showing high correlation with sites yielding Preclassic ceramics. Paradoxically, the technologically best celts also appear to be diagnostic of the Preclassic period as exemplified by large, elongate, symmetric celts which show a carefully 
executed fully-polished bit end. The bit-polishing technique is absent in the Tzakol 3 and Tepeu equivalent phases, reappearing as an Early Postclassic feature of a morphologically unrelated, bevel-nosed biface celt, a diagnostic artifact. Morphological variation, showing a decided aversion to clustering, of the admittedly limited Preclassic celt sample is unequalled in later phases. In terms of Maya Classic development, it is surely not insignificant that free-ranging variation in manufacturing technique, size and form gives way to marked standardization by the end of the Early Classic period.

The Formative 1ithic assemblage at Dzibilchaltun is similar to the contemporary Rio Bec assemblage only in the general characteristic of local resource exploitation with the single significant exception of the sparse presence of obsidian. Unlike the Rio Bec assemblage, chert is poorly represented appearing mostly in the form of small flakes, few showing even simple deliberate retouch. There is hardly a chert implement worthy of the name represented. On the other hand, ground stone implements are well represented in the form of various limestone implements which probably functioned as smoothers and manos. Manos and metates of this period are primarily from poorly dressed, poor quality limestone. The manos are porous and often contain readily discernable marine shell inclusions. Manos are typically flat faced providing the basis for characteristically angular cross sections. Tapered cylindrical forms with round cross sections become dominant later in the sequence.

The presence of obsidian in both assemblages is similarly sparse but nonetheless significant. It indicates that the importation of material over long distances had developed prior to the development of more local interaction with immediate neighbors. A rounded prismatic blade platform is diagnostic of the few proximal fragments in both assemblages which appears to be related technologically to highland Mexico rather than highland Maya obsidian sources (Rovner 1975:101-110). The obsidian collections from throughout the sequences in the Rio Bec and at Dzibilchaltun fail to show any substantial on-site manufacture. Primary core production debitage is totally absent while a very small number of flakes, none of which show features which could conclusively characterize them as core platform rejuvenation debitage (Rovner 1974), are insufficient to demonstrate any significant level of local secondary industry production at either site at any time during their respective histories.

\section{INDUSTRIAL DEVELOPMENT OF THE EARLY CLASSIC}

In sharp contrast to the general expectation of dynamic development marking the Early Classic period at most sites including Becan, Dzibilchaltun undergoes a substantial decline in population and resident activity during its contemporary Early Period I phase. The lithic assemblage for this phase is correspondingly meagre and of little further concern unless particular importance is given to two individual artifacts; a fragment of barkbeater and a narrow, elongate chert biface pick vaguely suggesting affinities with the south (Belize?). There is also a change in the meagre obsidian sample from the Formative diagnostic rounded prismatic 
blade platform to a style showing much less ablation of the platform edge prior to blade removal resulting in the retention of a small planar portion of the core platform on the proximal end of the blade. A similar change in blade platform style does occur synchronously in the Rio Bec obsidian sequence.

The Early Classic period in the Rio Bec is ushered in with an enormous flurry of dynamic growth at Becan.

At some time during the second or third century A.D.... the Becan site was fortified by means of an enormous dry moat and parapet system.... (A1so) over 500 square meters of plaster flooring, four well preserved platform units, and one structure exceeding ten meters in height... With one exception, all of this activity was concentrated within the defensive perimeter. Major excavations at Chicanna produced no indications of Preclassic structural activity...(Bal1 1973:375-376).

The nature of the lithic evidence does provide a perspective on at least some significant aspects of the activity at Becan, particularly the fortifications. There is not a single shred of lithic evidence to suggest antecedent local conditions in the Late Preclassic which would develop into as massive an undertaking as the Becan ditch and parapet. In the absence of any critical natural 1 ithic resources there is no development of a specialized lithic industrial complex, no evidence of developing trade networks with neighboring regions and a total absence of 1 ithic weaponry. Furthermore, the limited sample of locally produced lithic implements dating to the post-fortress construction phase is disproportionately static, showing a direct continuation of Preclassic traits even to the presence of an elongate, polished-bit biface celt.

The only substantial change in the lithic collection, and substantial in the extreme, is a proliferation of the only non-local feature of the Preclassic assemblage--obsidian prismatic blades, a long-distance import item. In spite of considerably more extensive excavations in Late Classic and Early Postclassic units, more than $26 \%$ of the total Rio Bec obsidian collection, including the material from Chicanna, was recovered in Tzakol 1-2 equivalent Early Classic contexts at Becan, within the fortified zone. The highest density of obsidian was obtained from a context apparently representing an elite ceremonial cache of Tzakol 1-2 date which was badly disturbed during Tzakol 3-equivalent period modification and reconstruction of the extant structure (Ba11 1973:205). The obsidian collection from this context includes eight prismatic blades of Pachuca green obsidian, material of clear Teotihuacan origin. Several additional pieces of green obsidian were recovered from further excavations in the same vicinity (Stoltman 1975). This provides two important correlations; a continuation of the apparent highland Mexico origin of Preclassic phase obsidian as indicated by its technological features, and a second instance of cached green obsidian in the Maya lowlands dating well before the fifth century to match discoveries at Altun $\mathrm{Ha}$ by Pendergast (1971). The first appearance of projectile points occurs even later in the Early Classic. All but one are made of non-local material with the locally-made exception showing 
an anomalous manufacturing technique of probable foreign origin.

With the sum total of changes in the Early Classic lithic assemblages attributed to foreign influence synchronous with and subsequent to the construction of the Becan fortifications, all the lithic evidence points to foreign influence motivating its construction. It is obviously tempting to see that motivation originating from either Teotihuacan itself or an intermediate group linked to Teotihuacan. However, the only reported architectural antecedents are apparent7y located at Los Naranjos, Honduras (Baudez 1971). A massive ditch and parapet construction dates to the Eden phase which extends from 200 B.C. to A.D. 400 wholly overlapping the suggested time range for the building of the Becan fortifications. Indeed, in terms of antecedents, there is a large, but simple, ditch fortification construction dating to the earlier Jaral phase at Los Naranjos. Given the development of the Protoclassic Usulutan sphere it becomes tempting to see the Honduras and the Rio Bec fortifications as frontier outposts of that sphere. However, this contradicts not only the suggested Highland Mexican influence at Becan, but even more cogent ceramic data to argue against the presence of significant UsuTutan sphere influence.

... it is noteworthy that defensive measures seem to have been undertaken just at that time when intrusive elements were pushing their way westward and northward into the Maya lowlands. No true Protoclassic stage material was encountered at Becan, despite its proximity to Holmul (less than 140 kilometers away). Usulutan types, present 125 kilometers south of Becan at Uaxactun and 290 kilometers northeast on the coast at Tancah, have been neither at Becan nor inland to its north... It is difficult to believe that the absence of intrusive Protoclassic ceramics from Becan and that center's second through third century growth are not casually inter-related (Ba11 1973:375-376).

Furthermore, the large, triangular bodied, unifacially retouched "dagger" with wide shoulders and bifacially flaked stem, distributed from Chalchuapa, Honduras, to Chiapa de Corzo, Chiapas, to Belize and the Peten, is absent in the Rio Bec collections. The glaring discrepancy between the architectural relationships and the ceramic and lithic evidence clearly demands resolution.

The fourth and fifth centuries of the Early Classic period mark the first phase of major activity at Chicanna. The earliest manifestation of activity comes from a buried soil beneath the initial major architectural construction at Chicanna but is not necessarily related to that construction. The buried soil yielded a concentration of over 1000 pieces of local chert debitage. In spite of the relatively mediocre quality of the local chert, more than $15 \%$ of the debitage shows characteristics of a percussion blade technology while two chert cores in the sample appear to be blade core rejects. In addition 39 simple unifacially retouched implements, mostly beaks and gravers, were recovered, fully one-third of which were made on preforms classified as blades. There is no other significant incidence of chert blade production or selection of local chert blades as preforms for the manufacture of unifacially retouched implements anywhere 
in the Rio Bec collections. It appears to be an intrusion of an alien technology into the Rio Bec near to, but outside, the fortified zone at Becan which was not incorporated into the subsequent chert industries either at Becan or at Chicanna. Although the retouched implements are superficially related to the flake beaks and gravers typical of the traditional local chert industry, there is also a clear differentiation in average size and size range of the implements in this anomalous Chicanna industry. The 39 Chicanna flake and blade implements, of comparable size to each other, are distinctively smaller than their flake counterparts in the rest of the Rio $\mathrm{Bec}$ assemblage. Although this anomalous occurrence of chert blade tools in a restricted Early Classic context is not unique, Kidder (1947:6) illustrates 10 implements which appear to be beaks-on-blade from a single restricted Early Classic context at Uaxactun; the area of origin for this industry is not apparent. Inasmuch as the Rio Bec ceramics show minor changes in the fourth and fifth centuries with affinities to ceramics from Belize (Ball 1973), I am inclined to place the origin of this industry in that general area which also contains native resources of quality chert which would foster development of a local chert blade technology.

The appearance of projectile points during the Early Classic has several implications for developments in the Rio Bec. The small sample size, only eleven, and all from Becan itself, does not reflect the significance they represent. Ten are bifacially flaked, of which five are made of obsidian, one gray and four Pachuca green. A11 10 are fragments or are badly broken. None were found in cache or ceremonial context; indeed, three of the four green obsidian points are in contexts directiy associated with the fortifications. Ball (1973) notes the possibility of a fifth century "downfall" of the Becan fortress to Teotihuacan and/or highland Mexico-allied forces are a prelude to the final phase of the Early Classic which shows substantial Teotihuacan influence in the ceramic assemblage. He further notes (Ba11 1973:380) the presence of large quantities of scattered human bone in most pure deposits of this period. To further confuse the issue of who was competing with whom, if anyone, for control of Becan during the fifth century, the eleventh Early Classic point is a small, unifacially retouched, stemmed point-on-blade made of local chert. The technological affinities are clearly to the anomalous al ien chert blade industry at Chicanna, but the point, perhaps not surprisingly, was recovered from a context in association with the Becan fortifications. The permutations of possible explanations given the incomplete evidence strain the imagination.

\section{INDUSTRIAL DEVELOPMENT OF THE LATE CLASSIC}

The Late Classic period comparison of the Dzibilchaltun and Rio Bec lithic developments continues the general pattern of distinctly opposite trends, but in this instance representing a reversal of the Early Classic pattern. Following the apparent demise of widespread Teotihuacan influence in the Maya region, the $\mathrm{Rio} \mathrm{Bec}$ underwent an initial retrenchment to a markedly localized development. Ceramic ties to the Peten disappear while distinctive Chenes-Rio Bec architectural and ceramic styles develop directly out of antecedent Early Classic forms (Ball 1973). Virtually a11 of the 
indications of disparate foreign influences in the Early Classic Tithic assemblages are either substantially diminished or disappear entirely. In sharp contrast, Dzibilchaltun rises out of its doldrums to the peak of its development socially, architectural1y, etc., (Andrew IV 1965) with evidence of substantial interaction with neighboring and distant groups readily apparent in the lithic collection.

The absence of local chert resources at Dzibilchaltun appears to have precluded development of any local lithic industrial development at the site. The chert debitage of this period of maximum development shows no change from the Preclassic pattern, no chert nodules, reject cores, decortication flakes or large trimming flakes occur in the collections. Indeed, there is not even a substantial change in absolute quantity of small flake debitage recovered as compared to the Preclassic (Formative) collection. Considering the more extensive excavations in units of this later phase, which included substantial testing of house mounds as well as exploration of elite precincts, it might be suggested that even less lithic production activity took place at the site than even the rather meagre level indicated for the Formative. Obsidian importation is at its peak; imported fine quality 1 imestone implements clearly predominate at the expense of implements of porous local material; and chert projectile points make their initial appearance in the sequence. The few diagnostic points are simple lanceolates or ovals. Stemmed points appear toward the close of this period while notched points are clearly a Postclassic-equivalent period occurrence. In addition a cache containing a pair of large, bifacial daggers (i.e., ceremonial knives), one made of fine brown chert and the other of gray obsidian, date to this period. Dzibilchaltun necessarily relied almost entirely on foreign industry and exchange to provide for all its utilitarian and relevant ceremonial 1 ithic requirements.

With the subsidence of Early Classic foreign activity in the Rio Bec, a return to manifestation of local lithic industries and industrial traditions dominates the collections. In the Tepeu 7-equivalent phase, obsidian is imported at substantially diminished levels and is once again the only apparent utilitarian lithic import. Not one example of the ceremonial chert and obsidian eccentrics which typify the Late Classic in the Peten and Belize was found in the Rio Bec. Green obsidian does not again appear in this sequence. Local chert is used to manufacture bifacial projectile points for the first time; but, coincidentally with the points from Dzibilchaltun, only simple lanceolates are produced. The earliest possible date for stemmed points is the Tepeu 2-equivalent phase, but invariably in deposits mixed with Tater material. It is very likely that stemmed points do not appear in the Rio Bec until the Terminal Classic. Biface celt and unifacial flake tool manufacture is once again the most prominent feature of the lithic assemblage. Whereas there is little to distinguish the flake tools of this period from their counterparts in the Preclassic, clear distinction is evidenced in the celt collection. The polishing finish technique is absent; size clusters in the short-broad range; elongate celts are absent; and morphological types cluster in the rounded cordiform to oval zone. The apparent uniformity to size and form is further enhanced by the absence of crudely flaked, irregular celts and 
suggests a development toward standardization, if not also occupational specialization, of the local celt manufacturing industry. Elaboration, as well as standardization, of the local lithic industry takes place. In addition to the biface points, the most prominent implement is the "domed smoother", a halved nodule of chert with decortication flake removals around the circumference. Apparently similar implements were named "Scraper, turtle-backed" by Kidder (1947) at Uaxactun. Because of the relatively crude nature of the implement, they may have been dismissed as discarded cores since they have not been reported at any other Maya sites. However, a broad distribution for them is indicated by their presence in quantity at the sites of Yagul and Mitla in Oaxaca (Hester and Heizer 1972) and given the name "scraper planes". As reported at Mitla, the most frequent context for the Rio Bec implements is constructional hearting and rubble. Eight of the Rio Bec implements show clear evidence of stucco incrustation providing the suggestion of functional association which led to the selection of the term "domed smoother".

The developments in lithic industries during the Rio Bec Late Classic period contrast sharply with both the contemporary developments at Dzibilchaltun and its own previous Early Classic assemblage. The Rio Bec Maya apparently turned inward, intensifying and elaborating their traditional industrial activities reliant primarily on the exploitation of locally available resources.

\section{INDUSTRIAL DEVELOPMENT OF THE TERMINAL CLASSIC}

The Terminal Classic period in the Rio Bec is marked by essentially the same cultural collapse suffered by Maya Classic centers throughout the southern and central Lowlands. Manifestations of the local Rio Bec industries remain unchanged, a condition based on typological continuity which could mask significant change in the social and economic aspects of the local lithic industry. Manifestations of foreign 1ithic industries in the Rio Bec begin a superficially similar recapitulation of the character of the Early Classic period. The earliest of these is the appearance at both Becan and Chicanna of stemmed bifacial and stemmed unifacial points made of fine brown chert. They are typologically identical to points characterizing the previous Late Classic period in the Peten, in Belize, etc. This time discrepancy in their respective area appearances suggests at least two explanations: the Rio Bec again established interregional relationships with neighboring areas to the south; or, the Rio Bec began to receive migrations of people out of the culturally collapsing regions. Inasmuch as the Terminal Classic is a period of disintegration rather than growth, the latter hypothesis would seem the more reasonable of the two.

The high level of activity at Dzibilchaltun appears to have continued unabated, at least insofar as the level of lithic importation of obsidian, etc., is concerned. However, the absence of good stratigraphic separation of much of the lithic collection of this period from the previous makes valid quantitative comparisons difficult. To a significant degree the florescence of the Puuc centers south of Dzibilchaltun may have begun to divert the flow of imported items as a prelude to a second decline which is clearly manifested in the subsequent phase of the Dzibilchaltun 
sequence. The development of the Puuc centers is not without its effects further south in the Rio Bec. Indeed, the Terminal Classic period at Becan is marked by the influx of material, both ceramic (Ball 1973) and lithic, from northern Yucatan. The diagnostic lithic element of this influx is a narrow, elongate biface point having narrow shoulders and a rounded stem. The distribution of this point suggests a specialized function or functional complex inasmuch as all but one of the 18 points of this type were recovered from the interior and exterior middens of a single structure, a multi-story pyramid (Structure IV), located inside the fortified zone at Becan. The single exception was recovered at the site of Xpuhil 2; none were found at Chicanna. The Becan middens which yielded the points also produced over 1,000 pieces of local chert debitage more than 800 of which were fire spalled, fire crazed, heat discolored or smoke hazed. Thermal damage was also common on the points themselves absolutely precluding the possibility of the technique of thermal treatment prior to flaking. The heat damage was so great in many instances that the stone would have been impossible to flake in any semblance of controlled fashion.

The narrow elongate point type was found in museum collections from the site of Uxmal in the Puuc Hills and Proskouriakoff (1965) illustrates examples, which also show heat damage, from the sites of Santa Cruz and Chacchob in northern Yucatan. A body fragment found at Dzibilchaltun which shows fire crazing may also belong to this type. However, the external relationships of this restricted lithic sub-assemblage are not so simple. Donald Brockington (personal communication 1973) identified the point type as diagnostic of the Epiclassic period in Oaxaca. A11 these occurrences may be local manifestations of a broadly ranging sphere of interaction which Ball, using ceramic evidence, sees as part of a "continuous militaristic expansion on the part of the central highland-oriented, Gulf Coast Putun (Chontal) Maya" (Ball 1973:389). Following, as it does, on the heels of the appearance of points of Peten or Belize derivation, this parade of separate groups interacting with the local Rio Bec Maya poses a situation resembling the character of the Early Classic.

\section{INDUSTRIAL DEVELOPMENT OF THE POSTCLASSIC}

The character of the Postclassic assemblage in the Rio Bec continues the trend of the Terminal Classic period. Only one change occurs in the locally related industries, represented by the appearance of the elongated, bevelnosed biface celt which also shows the employment of the polished bit technique. There are no other discernable changes in the typological configuration of the local 1ithic implement assemblage. In sharp contrast foreign elements continue their intrusions into the area, in several cases adding new and different materials suggestive of a broader area of interaction. In fact, we are faced with the paradox that the collapse and postcollapse periods provide the greatest variety of diverse 1 ithic imports into the Rio Bec. Long distance exchange, a normally defining characteristic of the stage of peak civilization, appears to be rising as civilization is breaking down. Obsidian importation, while not reaching the levels of the Early Classic, does show a discernable increase over Late Classic levels, with the fully ground platform style dominating the 
prismatic blade collection. Basalt manos and metates appear for the first and only time in the sequence. The 12 pieces recovered would not be as extraordinary a collection if it were not for the total absence of the material in any of the earlier periods. Three fragments of a single metate, made of a pink and gray granite, apparently from the quarry at Mountain Pine Ridge, Belize (Bullard and Bullard 1965), is the only granite artifact in the collection and dates not earljer than the Terminal Classic. Barkbeaters also appear in the collection. Projectile points show a tremendous variance in style and material. Local cherts, fine imported cherts and obsidian points are present in the collection. Types run the full range from simple lanceolates to stemmed to cornernotched, side-notched and expanded base varieties with both unifacial and bifacial points represented. Inexplicably, all the various notched point types diagnostic of the Postclassic appear at Chicanna, none from Becan. Given the earlier northern intrusion which avoided Chicanna, the exact relationship of these two sites to each other over time raises several unresolved questions. Large biface daggers occur in the Rio Bec collections for the first time, most made of fine brown chert. In earlier times, such a range of material might be interpreted as representing dynamic growth, far reaching economic and/or political alliances. Coming at a time of cultural disintegration, one can only wonder at the degree to which such activity might represent chaotic upheavals over broad areas.

Several of the elements characterizing the Postclassic at Becan appear at the same time at Dzibilchaltun. A variety of notched points appear, as do barkbeaters, obsidian prismatic blades with the fully ground platform, basalt, and fragments of the fine brown chert biface dagger. The "dogbone" mano and small, tripodal basalt metate (palette?) appear at Dzibilchaltun. Dzibilchaltun at this time, however, is also in eclipse, but in this case most probably due to the domination of the north coast by the Toltec influenced occupation at Chichen Itza. With the demise of Toltec influence, Mayapan grows to dominate the northern area with activity at Dzibilchaltun at a significant but subordinate level. The closest approximation to any local chert industry occurs at Dzibilchaltun. Nearly 100 small chert blades were recovered from structures showing strong Decadent period occupations. Although the blades, or bladelets, were probably produced from prepared cores, no examples of the latter were recovered. Nine marginally retouched, side-notched points-on-bladelet are diagnostic of the Decadent occupation at the site and, indeed, at several other Postclassic sịtes; including 15 found at Mayapan (Proskouriakoff 1965) and eight green prismatic biades were recovered variously from the surface of Decadent period shrines at Dzibilchaltun. The most substantial occurrence of green obsidian in the Lowlands dating to this period is the relatively large mortuary cache assemblage recovered from the burial mound at Atasta, Campeche (Ball and Rovner 1972). The arrival of the Spanish, of course, leaves the ultimate consequences of Aztec interaction with the Maya Lowlands solely to the imagination. 


\section{REFERENCES CITED}

Andrews IV, E. W.

1965 Archaeology and Prehistory in the Northern Maya Lowlands: An Introduction. In: Handbook of Middle American Indians, 2:228-330. University of Texas Press, Austin.

Ba11, J. W.

1973 Ceramic Sequence at Becan, Campeche, Mexico. Ph.D. dissertation, University of Wisconsin.

Ba11, J. W. and I. Rovner

1972 Protohistoric Putun Trade Patterns: Evidence from Two Graves at Atasta, Campeche. Katunob 8(2):40-46.

Baudez, C. F.

1971 Commentary on: Inventory of Some Pre-Classic Traits in the Highlands and Pacific Guatemala and Adjacent Areas. In: Observations on the Emergence of Civilization in Mesoamerica. (edited by R. F. Heizer, J. A. Graham and C. W. Clewlow, Jr.) Contributions of the University of California Archaeological Research Facility 11:78-84.

Bullard, W. R., Jr. and M. R. Bullard

1965 Late Classic Finds at Baking Pot, British Honduras. Occasional Papers. Royal Ontario Museum, Toronto.

Coe, M. D.

1961 La Victoria, an Early Site on the Pacific Coast of Guatemala. Papers of the Peabody Museum, Harvard University 53.

Coe, M. D. and K. V. Flannery

1967 Early Cultures and Human Ecology in South Coastal Guatemala. Smithsonian Contributions to Anthropology 3.

Hester, T. R. and R. F. Heizer

1973 Problems in the Functional Interpretation of Artifacts: Scraper Planes from Mitla and Yagul, Oaxaca. Contributions of the University of California Archaeological Research Facility 14:107-123.

Kidder, A. V.

1947 The Artifacts of Uaxactun, Guatemala. Carnegie Institution of Washington Publication 576. 
Kidder, A. V., J. D. Jennings, and E. M. Shook

1946 Excavations at Kaminaljuyu, Guatema1a. Carnegie Institution of Washington Publication 561.

Lee, T. A., Jr.

1969 The Artifacts of Chiapa de Corzo, Chiapas, Mexico. Papers of the New world Archaeological Foundation 26.

Pendergast, D. M.

1971 Evidence of Early Teotihuacan--Low1 and Maya Contact at Altun Ha. American Antiquity 36(4):455-460.

Proskouriakoff, T.

1962 The Artifacts of Mayapan. Carnegie Institution of Washington Publication 619, Pt. 4.

Ricketson, O. G., Jr. and E. B. Ricketson

1937 Uaxactun, Guatema $7 \mathrm{a}$, Group E; Carnegie Institution of washington Publication 477.

Rovner, I.

1974 Evidence for a Secondary Obsidian Workshop at Mayapan, Yucatan. Newsletter of Lithic Technology 3(2):19-27.

1975 Lithic Sequences of the Maya Lowlands. Ph.D. dissertation, University of Wisconsin.

Shook, E. M. and A. V. Kidder

1952 Mound E-111-3, Kaminaljuyu, Guatema1a. Carnegie Institution of Washington Publication 546.

Stoltman, J. B.

1975 An Analysis of Chipped Stone Artifacts From Becan, Campeche, Mexico: A Case Study of the Value of Detailed Lithic Analyses in Complex Societies. Unpublished manuscript.

Thompson, J. E. S.

1939 Excavations at San Jose, British Honduras. Carnegie Institution of Washington Publication 506. 
Willey, G. R., W. R. Bullard, J. B. Glass, and J. C. Gifford

1965 Prehistoric Maya Settlements in the Belize Valley. Papers of the Peabody Museum, Harvard University 54.

Wi17ey, G. R.

1972 The Artifacts of Altar de Sacrificios. Papers of the Peabody Museum, Harvard University 61(1). 
THE TERMINAL PRECLASSIC LITHIC INDUSTRY OF THE SOUTHEAST MAYA HIGHLANDS:

A COMPONENT OF THE PROTOCLASSIC SITE -

UNIT INTRUSIONS IN THE LOWLANDS?

Payson D. Sheets

INTRODUCTION

To date, the Protoclassic problem in the Maya lowlands has been discussed largely in terms of ceramic typology and dating (cf. Willey and Gifford 1961, Willey 1973, Willey, Culbert and Adams 1967, and others). It is the purpose of this paper to begin a broadening of our understanding of the Protoclassic phenomenon by investigating whether lithic artifacts might have been a component of a potential intrusion. The term lithic is used here in the broad sense to subsume both chipped and ground stone artifacts.

This paper is exploratory, for the detail, objectives, and standards of highland and lowland lithic analyses have varied considerably in 20th century Maya research. This variation, in many cases, is sufficient to obviate firm comparisons and conclusions, but at least at two sites where the Protoclassic seems to have been a sudden intrusion, Altar de Sacrificios and particularly Barton Ramie, Tithic description and illustration are detailed enough to allow for meaningful comparison and some tentative conclusions. Fuller examination of the lithic component of the Protoclassic must await future detailed excavations and analyses. For these, this paper is intended to point out likely lithic components of the Protoclassic to be considered, and accepted, rejected, or modified as the evidence demands.

In a more general context, if the hypothesis were correct that the eruption of Volcan Ilopango in the southeast Maya highlands shortly after the time of Christ did create sufficient environmental modification over an extensive area occupied by peoples already making Protoclassic-style artifacts, then we would expect to see the following in areas to which people migrated:

1. Population increase

2. Acceleration of culture change

3. Intrusive elements of material culture
a. Ceramics
b. Lithics
c. Other (including architecture, sculptural styles, and additional artifact industries) 
Wi1ley et al. (1965:27, 565) encountered evidence for an approximate doubling of population at Barton Ramie, indicating that $\# 1$ above apparently occurred at least at one site receiving the Protoclassic ceramic intrusion. An acceleration of culture change at about this time (C. A.D. 200) has long been noted in the Maya area; it is partially responsible for archaeologists drawing a taxonomic boundary separating the Preclassic from the Classic at about that time. Ceramics (3a) were the earliest component of the phenomenon noted, and they still serve as the hallmarks for it. Lithic artifacts (3b) should be indicative of an intrusion, if an invasion actually occurred, but research is insufficient to thoroughly test this now. Little more than a framework for testing can be constructed at this point.

In testing a lithic component of the migration-intrusion hypothesis it would be unreasonable, for a number of reasons, to expect wholesale importation of the southeast Maya highland material culture unchanged. A major one is ecologic. The majority of the inhabited area damaged by the tephra (ash flow and airfall ash) ranges from 500 to 1000 meters in elevation, and all of it is in the seasonal tropics, where over $90 \%$ of the precipitation is limited to the six-month rainy season. The BelizeSouthwest Peten area which may have received many of the immigrants is closer to true tropical rainforest conditions with many evently distributed convectional and orographic rains. The resultant highland vegetation in heavily inhabited areas is a deciduous to semi-deciduous broadleaf forest on a more nutriment-rich porous soil, while the lowlands are characterized by a tropical rainforest of broadleaf evergreen trees on a poorer soil. Material culture is a component of adaptation, and we should expect some significant adaptive adjustments to be made by the immigrants. Further, they did not arrive in an uninhabited area, but were immediately in contact with the lowland Maya and their indignous lithic traditions. And, the specific lithic resources available shifted from an abundance of obsidian, andesite, and basalt to an abundance of chert, limestone, and to a lesser degree, quartzite.

Nevertheless, the sudden arrival of a large number of foreigners should be detectable in the archaeological record, given sufficient knowledge of their material culture prior to the move and detailed information of the material culture in the recipient area prior to, during, and after the purported immigration.

\section{THE LOWLAND PROTOCLASSIC}

Explaining the sudden arrival of Protoclassic artifacts into a number of sites in the eastern-southern Maya lowland area has been a recurrent problem for Mayanists for almost 70 years. The Problem was first recognized from Merwin's excavations at Holmul in 1910-11, where mammiform tetrapod vessels, Usulutan decoration, spouted vessels, and pot stands were recognized as intrusive by Merwin and Vaillant (1932). They also noted the strong resemblance of artifacts from the southeast Maya highlands (EI Salvador area). The following summary of 7 iterature on the Protoclassic in the highlands and lowlands is adapted from our report on 1975 research to the National Science Foundation. 
Numerous other sites in the Maya lowlands have been found to have experienced a similar site unit intrusion sometime near the time of Christ. The artifacts have been known by a number of names, including Holmul I, Cimi, Matzanel, Salinas, Contutse, and Floral Park. The name Protoclassic may be used to subsume these similar materials. An excellent summary of the distribution of Protoclassic artifacts in southern Mesoamerica, particularly in the Maya lowlands, is that of Willey and Gifford (1961). They note the fu11 occurrence of the Protoclassic at such sites as Barton Ramie, Holmu1, Poptun, Mountain Cow, Nohmul (Douglas), Santa Rita, and Pomona. It has also been found at Altar de Sacrificios (Willey, Culbert, and Adams 1967:298; Willey 1973:34-39).

Sites with a few scattered Protoclassic artifacts, or lacking the evidence of a major, sudden infusion of the full Protoclassic are Uaxactun, Tikal, Finca Areva7o, Seibal, Chiapa de Corzo, Monte Alban, Kaminaljuyu, and southern Campeche. Willey and Gifford (1961:167) view the Protoclassic at Barton Ramie as an intrusion of a constellation of foreign characteristics into an indigenous technological and stylistic continuum. The intrusion does not break that continuum, and it is eventually absorbed into the general Early Classic culture.

Although the Protoclassic spread of artifacts might be explained by the opening of a new exchange or trade network, Willey and Gifford (1961: $168,1970)$ believe that a migration is the most likely explanation. They are uncertain of the source, mentioning northern Honduras, or, more likely, the Maya highlands. In retrospect, we can say that their suspicions may have been quite correct, and we may now be able to add the reason for the migration as well as the specific area of origin.

At Barton Ramie during the Floral Park Phase (the Protoclassic) a number of cultural and natural events occurred at approximately the same time, and they may have been interconnected. The dating of these events is not exceeding Ty precise; they occurred sometime between 100 B.C. and A.D. 300 (Willey et al. 1965:26-27). These changes (cf. p. 565) include at least a doubling of population as evidenced by a more than twofold increase in "house occupations", new ceramic characteristics interjected into the autochthonous continuum, barkbeaters, perforated potsherd discs (probably whorls), and apparently certain other artifacts. Among the ceramic changes, a new ceramic type appears, Aguacate Orange, which is so similar to sub-ash ceramics in ET Salvador as to be indistinguishable by ceramicists working at Barton Ramie and Chalchuapa (Sharer and Gifford 1970). These cultural changes are accompanied by the virtual disappearance of freshwater mussels and univalves from Barton Ramie. The acute sensitivity of aquatic species (animals and plants) to damage by tephra (Malde 1964) may be directly relevant here. In fact, if an ash fall radically diminished shellfish, fish, and related species in Belize, the same phenomenon should have occurred elsewhere. It may not be mere coincidence that the Ocos area of Pacific Guatemala-Chiapas, where the Preclassic occupation was heavily dependent on aquatic protein resources, was abandoned in the Early Classic, and then thoroughly reoccupied a few centuries later (Coe and Flannery 1967:84-91). At Bilbao, more inland on the 
Guatemalan Pacific coastal plain, Parsons (1967:24) encountered a marked diminution of cultural materials in the Early Classic which may be indicative of a population decline, but not of an abandonment of the area. Because the Bilbao inhabitants apparently were not relying much on aquatic protein resources, I would expect.their agricultural subsistence base to have been less sensitjve to a tephra-induced perturbation than their Ocos nejghbors. Bilbao is $140 \mathrm{~km}$ and 0 cos is $215 \mathrm{~km}$ WNW of I lopango.

The evidence of substantial flooding of the Belize River was encountered at Barton Ramie in the form of a sterile brown clay stratigraphically separating the Preclassic from later occupations and humic horizons:

We noted that mounds whose construction began in Preclassic Period times had their bases directly on or slightly into the (buried) black soil stratum, while mounds whose construction began at a later date had brown clay intervening between the mound base and the black soi1" (Willey et al. 1965:31).

This flooding occurred at about the same time as the molluscs diminished and the Protoclassic cultural-demographic intrusion. Flooding is a common result of tephra damage to vegetation in the drainage basin of rivers, often exacerbated by the greatly increased rainfall.

From Tikal Project excavations during the past two decades it is clear that the roots of the Classic Maya florescence in the Peten are deeply embedded in the Peten Preclassic, therefore we cannot mechanistically derive the lowland Classic out of the highland Preclassic. However, it is likely that the sudden arrival of large numbers of people on the peripheries of the "core area" necessitated an intensification of social and political control mechanisms, thereby accelerating the rate of cultural development. The Protoclassic may have acted primarily as a catalyst instead of being a critical reagent in the emergence of the classic Maya state and civilization.

The controversy over the nature of the Protoclassic continues among Mayanists working in the lowlands. Willey (1973) and Adams (1971) recently disagreed on the explanation for the large amounts of Protoclassic materials encountered during their excavations at Altar de Sacrificios of the Salinas Phase (A.D. 150-450). They both agree that the Salinas Phase was a time of rapid change in ceramics, trade, architecture, artifacts, and iconography. Adams explains this by an influx of population into Altar, accompanied by some violence and the invaders establishing themselves as the rulers, with the earlier resident population becoming the ruled. Willey (1973:38-39) had earlier favored the invasion explanation, but he now expresses some reservations by viewing the Protoclassic phenomenon as deriving out of "culture change benefiting by stimulation from foreign contacts."

Willey (1973:36) does note that the indigenous continuum of Altar utility wares was unbroken from the previous Plancha Phase through the Salinas Phase. The first "luxury ware" at Altar derives from the intrusive Protoclassic. If there were a Protoclassic invasion, then these two traditions 
and their social functions can be used to trace the dynamics of ethnic interactions. Immigrant groups usually enter pre-existing non-egalitarian societies either on the lowest or the highest socio-economic leve1; rarely are they accepted by the inhabitants at precisely the same level. It would appear that the highland immigrants at Altar and Barton Ramie were socially (and probably politically and economically) dominant at least for the first few generations after the migration.

However, as Schwartz (1970:178) notes in discussing the developmental phases of postmigration cultures, the community ultimately may develop along lines quite different from those of either of the two separate groups. Although at Altar and Barton Ramie the intrusive socio-technic artifacts are initially dominant, the overa 11 Maya lowland developmental continuum from the Late Formative into the Classic overwhelmed the Protoclassic cultural intrusion within a few generations. A11 the sites which may have received a significant site unit intrusion were, by the 5 th century, fully within the Classic Maya realm.

The late facet of the Cantutse (Chicanel, or terminal Preclassic) Phase at Seibal contains many components of the Protoclassic complex, including mammiform tetrapod vessels, orange-slipped ceramics, and imitation "Usulutan" types (Sabloff 1975:11, 231-232). The Protoclassic at Seibal apparently is analogous to Tikal; in both cases there is no evidence of a full site-unit intrusion and sudden population increase, but rather Protoclassic elements show up gradually and individually, by trade or imitation. Even though the earliest ritual construction at Seibal dates to the late facet of the Cantutse Phase, Seibal evidently experienced a marked population decline as well as a "cultural decline" (pp. 11-12), with "much of the site (being) abandoned to the jungle." As Sabloff summarizes: "There is no evidence of a separate Protoclassic complex such as the Salinas at Altar de Sacrificios or Floral Park at Barton Ramie. Nor is there evidence of an intrusion of new peoples such as Adams sees at Altar" (p. 232).

\section{THE SOUTHEASTERN MAYA HIGHLANDS (EL SALVADOR AREA)}

Numerous investigators over the past 50 years in the southeast Maya highlands (Fig. 1) have encountered Preclassic artifacts under a layer of volcanic ash. Lardé (1926) was the first to record this artifactualstratigraphic relationship, followed shortly by Lothrop (1927). Two decades later more discoveries of comparable relationships began to be made by Dimick (1941:29), Boggs (in Longyear 1944; 1966), Porter (1955) and Longyear (1944:32) in central and eastern El Salvador.

Work of the Chalchuapa Archaeological Project, particularly in 1969 and 1970, documented the gradual development of the known elements of the Protoclassic complex, stratigraphically capped by the layer of volcanic ash (Sharer 1974), making possible the formulation of the hypothesis that explosive volcanism rendered uninhabitable a significant area of the southeast Maya highlands, and that a forced migration could be the explanation for the lowland Protoclassic intrusion. Prior to this research, a 


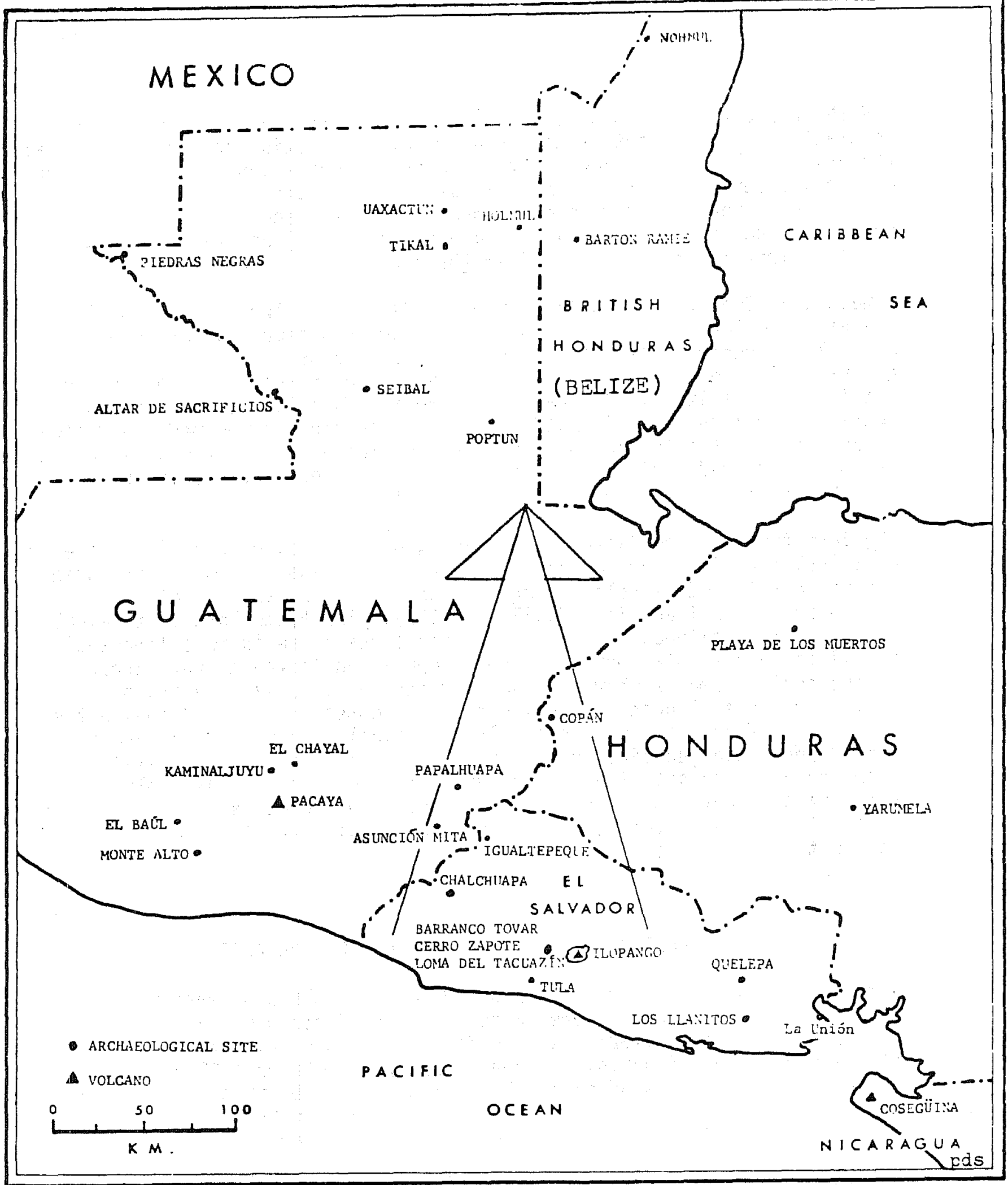

Figure 1. Map of sites in the southeast Maya highlands (El Salvador) devastated by the eruption, and sites in the Maya lowlands (N. Guatemala, Belize) affected by population movements. 
major deficiency in our data derived from the fact that all the sub-ash artifact discoveries in the highlands were site-specific, and virtually a11 were without any geologic, let alone tephrochronologic, analysis. We had enticing fragments of data which might indicate a large scale natural disaster, but both a regional scope and a consistent, multidisciplinary research strategy were lacking.

With these problems in mind, the 1975 research was directed toward determining if there was a relationship among these disparate finds of tephra overlying archaeological sites in the highlands. If the tephra deposits were in fact related, i.e. from the same eruption or series of eruptions, was the volcanologic event of sufficient magnitude to serve as a potential explanation, in the form of a migration, for the Protoclassic intrusion in the lowlands? According to the geologic analys is by Virginia Steen-McIntyre of the samples collected in June-July, 1975 the tephra shroud which blanketed the southeast Maya highlands is not a series of local, unrelated events separated in space and time, but a massive, complex eruption. As far as we presently know, this eruption occurred in three stages, two ashflows (nuees ardentes or glowing avalanches) followed by an airfall ash. The ashflows, consisting of incandescent clouds of pumice, ash, and gasses, rolled downhil1 and buried villages and forests in their paths as far as $45 \mathrm{~km}$ from their source. Shortly thereafter, perhaps hours to weeks, the airfall ash was deposited in a more uniform blanket over the countryside. Yet unpublished data from the German Geological Mission to El Salvador indicates Ilopango to be the source of these tephra, and our evidence is in accord (although not conclusive) with their source attribution.

In some areas the probability of human physical survival would have been slight. For example, the Cartografia site was a viliage suddenty buried by up to nine meters of hot ash flow material. Areas farther from the source which received less instantaneous destruction, but where the vegetation, soils and hydrography were severely altered by the acid ash, would be more likely source areas for human migrations.

I would estimate conservatively, based on present data, that the environmental impact of the tephra-fal1 was greater than the Preclassic Mayan technological capacity to adjust and continue their agricultural adaptation over at least $3000 \mathrm{~km}^{2}$. The density of settlement was high in the Late Preclassic, for the southeast Maya highlands had been settled by agriculturalists for over 1000 years preceeding the eruption, and archaeological evidence indicates a steady population growth throughout the Preclassic. So, even if we use a minimal population density figure of 10 people per square kilometer, some 30,000 people would not have been able to continue living in the highlands.

\section{ARTIFACT DESCRIPTIONS AND COMPARISONS}

\section{Chipped Stone}

The reduction strategy for manufacture of obsidian implements in the Late Preclassic (c. 200 B.C. - A.D. 200) southeast Maya highlands is core-blade, involving a significant behavioral change from percussion to pressure midway 


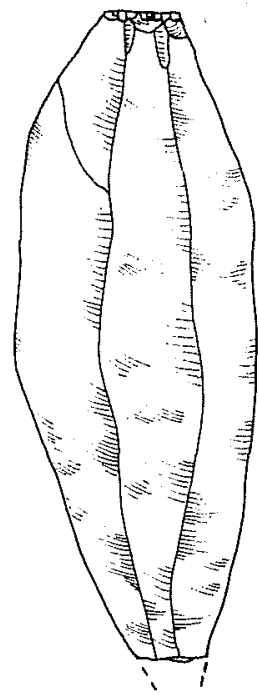

a

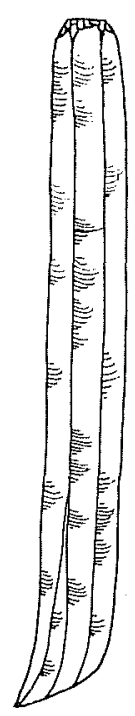

b

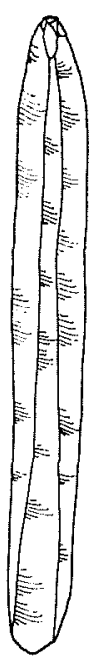

C

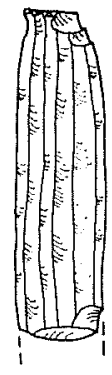

$d$

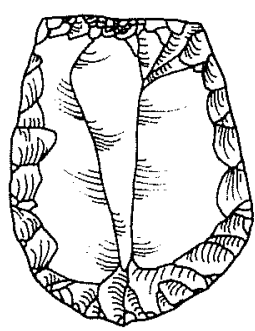

e
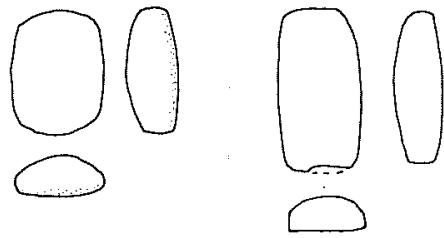

f

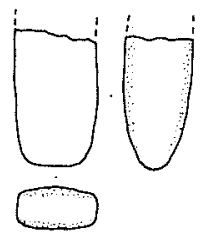

h
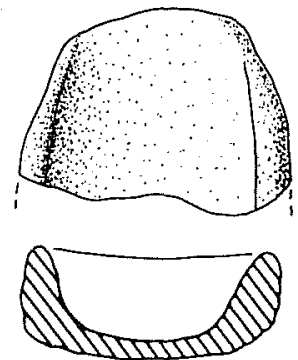

i

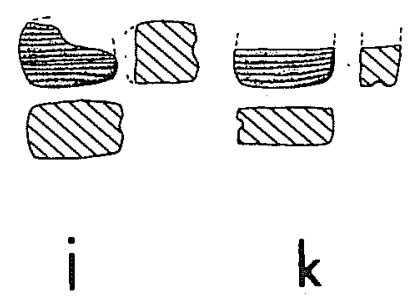

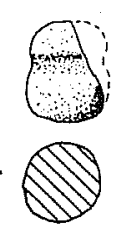

1
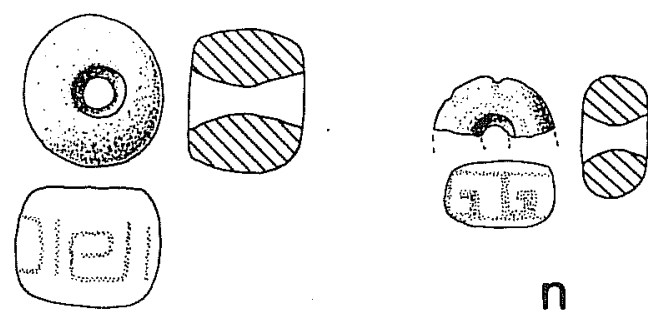

$n$

$\mathrm{m}$

Figure 2. Chalchuapa lithic artifacts: chipped stone and groundstone. a, Macroblade (large blade); b, Late Preclassic prismatic blade (note "scraping" overhang removal); c, Early Preclassic prismatic blade (note flake-by-flake overhang removal, smaller platform); d, Polyhedral core; e, Scraper; f, g, Ovoid thin plano-convex manos; h, Elongate, oval to rectanguloid mano; $i$, Rounded back trough metate; $j, k$, Barkbeaters; $1-n$, Biconically perforated stone discs ("donut stones", ringstones).

Chipped stone (a-e) 1/2 scale; Groundstone (f-n) 1/10 scale. 
in the process (Sheets 1972, 1974, 1975). The kinds of implements manufactured in the Late Preclassic involve prismatic blades, macroblades (Targe blades detached by percussion), scrapers, polyhedral cores, stemmed large blades, and occasionally other implements. Shook and Kidder's observation (1952: 113) of the paucity of bifacial manufacture in the highlands prior to the Classic has been substantiated by recent research (Sheets 1974:36). The following information about Chalchuapa and southeast Maya highland artifacts is drawn from Sheets $(1974,1975)$ unless otherwise noted.

The lack of bifacial flaking in obsidian also applied to some lowland Maya sites. Willey (1972:208 ff.) notes that bifacial flaking of obsidian does not begin at Altar de Sacrificios until the Late Classic. Willey (p. 212, 214) notes variation in platform preparation of polyhedral cores and prismatic blades but it is not temporally defined; so it is not possible to assess a potential core preparation component of the Protoclassic at that site.

A number of lines of evidence indicate a change in obsidian procurement and locus of manufacture in the highlands during the Late Preclassic. During the Early and Middle Preclassic the percentage of artifacts with cortex at Chalchuapa was consistently above $14 \%$, and occasionally above $20 \%$, indicating the importation of essentially unmodified obsidian cobbles into the site. Cortex percentages fal1 abruptly to $7 \%$ or less during the Late Preclassic through the Postclassic. This hypothesized shift toward preforming at or near the quarry is substantiated by the concomitant decline in the frequency of early preforming debitage at Chalchuapa. It appears Tikely that a more complex economic organization had emerged by this time, just prior to the Ilopango eruption. This evidently involved specialized preparation of the cores for transport, likely by a resident community of knappers at or near the quarry. This certainly was the case a few hundred years later, judging from the results of Graham and Heizer's (1968) brief study of PapaThuapa. With this change, consumption centers would have to trade for their obsidian in the form of prepared macrocores, instead of more directly obtaining their obsidian in raw nodule form.

Macroblades (Fig. 2a) were produced in large numbers by the Late Preclassic workshops in the highlands. The platform surface of most (usually over 60\%) is the unmodified flat flake scar of the macrocore platform, but some are lightly striated on the platform surface. This is particularly true of the smaller, more regular macroblades. The platform overhangs were consistently and thoroughly removed by a heavy "scraping" action, likely with a stone, leaving a welter of tiny hinge and step fractures on the dorsal surface of the blade immediately below the platform. This contrasts with the Early Preclassic careful (flake-by-flake, with flakes generally terminating in feather edges) removal of the overhang, and it also contrasts with the minimal removal of the overhang, by scraping, in the Late classic and Postclassic.

Similar macroblades abound at Papalhuapa (Graham and Heizer 1968:104), E] Chaya 1 (Coe and Flannery 1964:46), Copan (Longýear 1952), and other sites. I would not expect to find many macroblades in the Protoclassic materials in the lowlands, partly due to the increased scarcity/value of obsidian in the lowlands, but where they do occur, the above mentioned 
chronologically sensitive technological indicators should be identifiable.

Because of their greater frequency in both highlands and lowlands, prismatic blades (Fig. 2b-c) should be of greater assistance to us than macroblades in assessing the nature of the Protoclassic. The platform surfaces were consistently striated, and overhangs were rather thoroughly removed by the same scraping action described for macroblades. Platform dimensions of the Late Preclassic average $0.4 \mathrm{~cm}$ in Tength and $0.13 \mathrm{~cm}$ in width (measured from the dorsal to the ventral surface at the point of applied force, along the platform), but there is a rather large range of measurements. The percentage of prismatic blades to total chipped stone was surprisingly sensitive chronologically, beginning at ca. $5-10 \%$ in the Early Preclassic, rising to $\mathrm{ca} .40 \%$ in the Late Preclassic, and continuing to increase to between 50 and $70 \%$ in the Postclassic. Longyear (1952:109) noted the same phenomenon, on a shorter time scale, at Copan. However, we cannot expect these frequencies to rema in constant with a migration, largely because of intervening variables. We should expect the relative proportions of 7 ithic implements to change rapidly as people changed their location of residence and their adaptation, while the way in which they made those artifacts should change more slowly. Technology, then, should be a more sensitive indicator of a migration-intrusion than the relative frequency of implement types. But, technology certainly would not remain static, particularly as extended contact is established between knappers of the highland and lowland traditions.

Stemmed large blades at Chalchuapa date to the Preclassic, particularly to the Middle Preclassic. They are large blades unifacially retouched (or, preferably, "laterally retouched") along the proximal margins (ventral or dorsal). These are often called "daggers" in the Mesoamerican archaeological 1iterature. They have widespread distribution in Mesoamerica and areas of the Caribbean (W. Coe 1957). Of the numerous specimens from Barton Ramie, only one was from a datable context, and it was Early Classic (Willey et al. 1965:412, 422). That raises the possibility that these could be a component of the intrusion, for they are demonstrably earlier in the highlands. But, similar specimens were encountered in apparent Preclassic contexts at Uaxactun (Ricketson and Ricketson 1937:186-7). If other lowland specimens are found to date to the Preclassic, these "daggers" cannot be an intrusive component.

Scrapers (Fig. 2e) are another implement category manufactured from macroblade blanks, in this case by steep retouching of the distal and occasionally lateral margins of larger macroblades. All five types of scrapers from Chalchuapa were being manufactured during the Late Preclassic (Sheets 1974:78-84).

\section{Groundstone}

In very general terms, the groundstone industry reaches a relatively low ebb in manufacturing standards during the Late Preclassic in the southeast Maya highlands. The care shown in shaping manos and metates wanes throughout the Preclassic, but as legged metates begin to be made in the Classic, manufacture becomes more careful. 
The most common mano at Chalchuapa, the "Ovoid, thin plano-convex" type (Fig. 2f,g) began in the Preclassic and extended throughout a 17 time periods. Its counterpart at Barton Ramie, the "Rectangular-thin" type, dates to the Classic and perhaps to the Protoclassic Floral Park (Willey et al. 1965:459). The same applies to the Preclassic Chalchuapa "Cuboid" manos; they are comparable to the "Large-square" manos at Barton Ramie, and these latter date to the Classic (p. 457). Both are good candidates for inclusion in the Protoclassic intrusion.

The "Elongate, oval to rectanguloid" manos at Chalchuapa (Fig. 2h) date to the Middle Preclassic through the Postclassic. Comparable specimens at Barton Ramie may begin in the Preclassic (Willey et al. 1965:459). Even though the Barton Ramie specimens are somewhat wider, thicker, and shorter, the similarity and dating might be indicative of a direct relationship by the mechanism proposed here.

At Chalchuapa the "Rounded back trough metates" (Fig. 2i) begin in the Middle Preclassic, and evidently extend to the end of the Preclassic. This type in the lowlands is very common. It is called "Large metates" at Barton Ramie (Willey et al. 1965:453-454), where one unequivocal1y is dated to a context earlier than the Protoclassic. After the Protoclassic it is a common type, so we may have, in this case, not a standard case of intrusion of a previously unknown type. Rather, the increase in frequency of this already-established type may have as its explanation the arrival of numerous settlers who also valued it as a proper form for a metate. The same could apply to the "Elongate, oval to rectanguloid" manos above.

Barkbeaters at Chalchuapa ( $F i g .2 j, k$ ) extend chronologically from the Middle Preclassic through the Late Classic. They are rectangular in outline, and most are 3/4 grooved around the circumference. I suspect it is not by accident that virtually identical barkbeaters suddenly appear at Barton Ramie in the Protoclassic and continue through the Classic (Willey et al. 1965:469-471). A comparable dating distribution obtains at Altar de Sacrificios where a single wel1-dated specimen derived from a Late Preclassic context, and the type later (in the Late Classic) became much more common (Willey 1972:125-126).

Mauls (Fig. 21) from another taxon which could be part of the Protoclassic. They date to the mid-Late Preclassic at Chalchuapa, and to the Classic or possibly as early as the Protoclassic at Barton Ramie (Willey et al. 1965:466).

Biconically perforated stones ("donut stones" or ring-stones) are encountered frequently at Chalchuapa (Fig. $2 m, n$ ); they date from the Middle Préclassic through the Postclassic. They are rare in most areas of the lowlands, but they occur surprisingly commonly at Altar de Sacrificios. They may begin as early as the Late Preclassic at Altar, but most date to the Late Classic (Willey 1972:135-136). There appears to be a good chance that these "donut stones" could be a Protoclassic component as wel1. 


\section{CONCLUSIONS}

As stated above, only tentative answers can be offered to the question, were lithic artifacts a component of the Protoclassic intrusions into lowland sites just after the time of Christ? Bifacial flaking in obsidian evidently postdates the Protoclassic in both highlands and lowlands, and therefore it cannot be an intrusive element of the complex under investigation. Stemmed large blades do antedate the eruption in the higlands, and most seem to date to Classic contexts in the lowlands, raising the possibility that they may be involved in a Protoclassic migration.

Two types of manos which were made and used at chalchuapa prior to the eruption date to Classic and perhaps Protoclassic times as Barton Ramie. The same might obtain for rounded back trough metates, but this is less clear. A stronger case could be made for barkbeaters, at least as far as the Chalchuapa, Altar de Sacrificios, and Barton Ramie data indicate. Other groundstone candidates for inclusion in the Protoclassic intrusion are mauls and biconically perforated stones.

As lithic analyses become a more integral part of prehistoric Maya studies these artifact comparisons to determine the sources for technological or stylistic variables will be on a much more solid foundation. That will allow for detailed testing of ideas such as the migration-intrusion hypothesis offered by this paper.

\section{REFERENCES CITED}

Adams, R. E. W.

1971 The Ceramics of Altar de Sacrificios. Papers of the Peabody Museum, Harvard University 63(1).

Coe, M. D. and K. V. Flannery

1964 The Pre-Columbian Obsidian Industry of El Chayal, Guatemala. American Antiquity 30:43-49.

1967 Early Cultures and Human Ecology in South Coastal Guatemala. Smithsonian Contributions to Anthropology 3.

Coe, W. R.

1957 A Distinctive Artifact Common to Hajti and Central America. American Antiquity $22: 280-282$.

Dimick, J. M.

1941 Salvador (notes on excavations at Campana San Andrés, El Salvador). Carnegie Institution of Washington, Yearbook 40:298-300. 
Graham, J. and R. Heizer

1968 Notes on the Papalhuapa Site, Guatemala. Contributions of the University of California Archaeological Research Facility $5: 101-125$.

Lardé, Jorge

1926 Arqueología Cuzcatleca. Vestigios de una población preMayica en el Valle de San Salvador, C. A. , sepultados bajo una potente capa de productos volcánicos. Revista de Ethnología, Arqueologia, y Linguéstica $7: 3$ and 4. San Salvador.

Longyear, J. M. III

1944 Archaeological Investigations in El Salvador. Memoirs of the Peabody Museum, Harvard University 9(2).

1952 Copan Ceramics: A Study of Southeastern Maya Pottery. Carnegie Institution of Washington, Publication 597.

1966 Archaeological Survey of El Salvador. Handbook of Middle American Indians 4:132-156.

Lothrop, S. K.

1927 Pottery Types and Their Sequence in EI Salvador. Indian Notes and Monographs 1(4):165-220. Museum of the American Indian, Heye Foundation, New York.

Malde, H.

1964 Ecologic Significance of Some Unfamiliar Geologic Processes. In: J. J. Hester and J. Schoenwetter (eds.) The Reconstruction of Past Environments. Fort Bugwin Research Center.

Merwin, R. E. and G. C. Vaillant

1932 The Ruins of HolmuT, Guatemala. Memoirs of the Peabody Museum, Harvard University 3(2).

Parsons, L. A.

1967 BiTbao, Guatema1a. Milwaukee Public Museum, Publications in Anthropology $11(1)$.

Porter, M. N.

1955 Material Preclásico de San Salvador. Communicaciones del Instituto Tropical de Investigaciones Cientificas 3/4:105112. San Salvador. 
Ricketson, 0. and E. Ricketson

1937 Uaxactun, Guatema1a: Group E, 1926-31. Carnegie Institution of Washington, Publication 477.

SabToff, J. A.

1975 Excavations at Seiba1, Department of Peten, Guatema 1a:

Ceramics. Memoirs of the Peabody Museum, Harvard University 13(2).

Schwartz, D. W.

1970 The Postmigration Culture. A Base for Archaeological Inference. In: W. A. Longacre (ed.) Reconstructing Prehistoric Pueblo Societies: 178. University of New Mexico Press, Albuquerque.

Sharer, R. J.

1974 The Prehistory of the Southwestern Maya Periphery. Current Anthropology 15(2):165-187.

Sharer, R. J. and J. C. Gifford

1970 Preclassic Ceramics from Chalchuapa, El Salvador, and Their Relationships with the Maya Lowlands. American Antiquity $35: 441-462$.

Sheets, P. D.

1972 A Model of Mesoamerican Obsidian Technology Based on Preclassic Workshop Debris in El Salvador. Cerámica de Cultura Maya 8:17-33. Department of Anthropology, Temple University, Philadelphia.

1974 Differential Change Among the Precolumbian Artifacts of Chalchuapa, El Salvador. Ph.D. dissertation, University of Pennsyivania. University Microfilms, Ann Arbor.

1975 Behavioral Analysis and The Structure of a Prehistoric Industry. Current Anthropology 16(3):369-391.

Shook, E. M. and A. V. Kidder

1952 Mound E-III-3, Kaminaljuyu, Guatemala. Carnegie Institution of Washington, Publication 596, Contribution 53.

Willey, G. R.

1972 The Artifacts of Altar de Sacrificios. Papers of the Peabody Museum, Harvard University 64(1). 
1973 The Altar de Sacrificios Excavations: General Summary and Conclusions. Papers of the Peabody Museum, Harvard university 64(3).

Willey, G. R., W. R. Bullard, J. B. Glass, and J. C. Gifford

1965 Prehistoric Settlements in the Belize Valley. Papers of the Peabody Museum, Harvard University 54.

Willey, G. R., T. P. Culbert, and R. E. W. Adams (eds.)

1967 Maya Lowland Ceramics: A Report from the 1965 Guatemala City Conference. American Antiquity 32:289-315.

Willey, G. R. and J. C. Gifford

1961 Pottery of the Holmul I Style from Barton Ramie, British Honduras. In: S. K. Lothrop (ed.) Essays in Precolumbian Art and Archaeology:152-170. Harvard University Press, Cambridge. 


\section{MAYA OBSIDIAN TRADE IN SOUTHERN BELIZE}

Norman Hammond

The study of Maya 1ithic artifacts embraces not only the morphological, technological and functional aspects of the subject, but also those of the sources, destinations and means of transmission of raw material, which can be at least as informative, albeit on different facets of Maya society. The sources of stone may be microlocal, as is most building stone and much chert, and the Tocation of a site may be largely the result of available raw material (as at Colha); they may be local or regional, obtainable directly by a short journey beyond the bounds of the usual exploitation territory, or by exchange or redistribution with in the realm ruled from a single major center; or they may be exotic, brought from a considerable distance beyond the boundaries of the rea $7 \mathrm{~m}$. Within southern Belize a range of 1 imestones, sandstones, siltstones, slates and cherts were microlocal to some sites, local to others within the realm of Lubaantun (Hammond 1975), and this realm seems to have possessed within its boundaries, areas of the metamorphic quartzites of the Maya Mountains as wel1. A number of types of stone were definitely exotic, however, including the small quantity of jade and large numbers of vesicular lava (basalt) metates, as well as polished stone axes. A11 of these came from various parts of the Guatemalan highlands to the south, from the Motagua valley on their northern margin or from further away. Obsidian falls into this latter class, of exotic stone from the more distant regions of the continental divide.

During excavations in 1970 at Lubaantun, 113 fragments of obsidian flakeblades were recovered from Late Classic levels (Hammond 1975:340-343); the same season a collection of surface obsidian was made from Wild Cane Cay, a smal1 coral and mangrove island just off the coast, some $35 \mathrm{~km}$ east and north of Lubaantun (which 7 ies $25 \mathrm{~km}$ in 7 and). Test excavations on Wild Cane Cay in 1931 by Junius Bird (Hammond 1975:278-280; material unpublished in American Museum of Natural History, catalog 30.1/1474-1498) indicated a Late Classic into Early Postclassic sequence, and the presence of Tulum Red on the island suggests occupation or at least visitation into the 13th century A.D.

Initial analysis of one sample from each of the two sites, and four others from southern Belize, indicated that two obsidian sources were represented, Ixtepeque on the three island sites and EI Chayal on the three mainland ones. This information was collated with analyses from a number of other Maya lowland sites, all again single or few samples, and a model for obsidian trade routes suggested by comparison with ethnohistoric and ethnographic data (Hammond 1972). This model was described by Jay Johnson at this symposium as being a speculation founded on wholly inadequate data --but one which seemed to be substantiated by subsequent analyses; its progenitor would reiterate that "the model presented is a skeletal one; it will be interesting to see if the flesh fits the bones". This paper adds a pound of flesh in the form of further analyses from Lubaantun and Wild Cane Cay, together with single analyses from Moho Cay and Frenchman's Cay; no dating estimates are available for these last two, al though Late Classic ceramics have been found on the latter site. 
The analyses were carried out (by F. Stross and F. Asaro) by improved techniques: the sensitivity and precision obtainable with neutron activation analysis make study of source homogeneity attractive, and both the El Chayal and Ixtepeque sources have been studied in some detail. The results of this work are summarized here as a basis for the artifact attributions.

The El Chayal samples were collected by Stross from road cuts at 23, 24 and $25 \mathrm{~km}$ northeast of Guatemala City; those from Ixtepeque are stored at the University of California at Berkeley Archaeological Research Facility, and had been analyzed using neutron activation by Stross, Bowman and Asaro (unpublished data) prior to this study. About 50 elements were searched for and over 30 observed; the 10 that best distinguish the two sources are shown in Figs. 1-3, and any one of them is adequate to distinguish between Ixtepeque and El Chayal obsidian.

As an example of the reproducibility of the measurements, for the 16 most precisely measured elements, it was found that the average root-mean-square deviation was $1.51 \%$ for $12 \mathrm{El}$ Chayal source samples from the 24 and $25 \mathrm{~km}$ road cuts, and $1.57 \%$ for the four samples from the $23 \mathrm{~km}$ cut. With this precision it was found that there were very considerable differences in chemical composition between the obsidians from the $23 \mathrm{~km}$ and the $24+25 \mathrm{~km}$ cuts; the artifacts attributed to El Chayal match this latter source composition rather closely, al though small differences were observed, the largest being of about $5 \%$ in scandium. - These differences probably indicate that the artifacts came from a different part of the deposit than the source samples. A similar analytical division may be possible within the general Ixtepeque source area, where the volcano itself and the Agua Blanca source seem to have different levels of rubidium (Aspinall and Hammond, unpublished data on source samples collected by R. Sidrys; Sidrys, Andresen and Marcucci 1976); further samples are presently being analyzed to investigate this possibility.

In the present study 23 obsidian blade fragments from Wild Cane Cay were analyzed, 22 from Lubaantun and one each from Frenchman's Cay and Moho Cay nearby (not to be confused with Moho Cay off Belize City). Of the Wild Cane Cay sample 19 blades were assignable to the Ixtepeque source and four to El Chayal $(82: 18 \%)$. The two other cay samples were also assignable to Ixtepeque. Twenty-one of the 22 Lubaantun samples were assignable to El Chayal, and one to a third, unknown source; two blades from Ucareo, Michoacan, come from a source of very similar composition (Fig. 4).

These findings necessitate some changes in the model of Hammond (1972) as it applies to southern Belize: the model predicted that obsidian at the Lubaantun site should derive from both the Ixtepeque and the El Chayal sources, but none of the 22 samples comes from Ixtepeque, and the $95.5 \%$ representation of ET Chayal obsidian indicates rather that the "cacao route" along the Maya Mountains and up into Alta Verapaz was probably functioning at this period (Hammond, in press). The analyses of obsidians from Palenque and Tikal reported at the symposium by Jay Johnson and Hattula Moholy-Nagy also indicate a preponderance of El Chayal material, and the 
existence of the inland river-and-trail-based route network suggested for El Chayal by Hammond (1972) seems to be broadly substantiated, and the test expectations of the model fulfilled.

The Wild Cane Cay sample derived $82 \%$ from Ixtepeque and $18 \%$ from ET Chayal, suggesting that the inland-riverine and coastal trade route networks linked up at this ideal natural harbor (Hammond 1975: Fig. 105c); its nodal function is confirmed by the quantities of exotic materials, including Plumbate and Tulum Red pottery, from the Pacific coast and Yucatan respectively, and jade and copper artifacts found on a site which is structurally unimpressive and physically tiny.

The pattern of obsidian source assignation at Wild Cane Cay is more akin to that predicted originally for Lubaantun: it would seem that the conjunction of trade routes lay not at the major ceremonial center and regional capital, but at a subsidiary location where the large coasting canoes and the smaller river craft could meet. Whether Wild Cane Cay operated as a "trading port" or as a "port-of-trade" in the Classic to Early Postclassic period, in the manner that Sabloff and Rathje (1975) have suggested for the larger island of Cozumel off the coast of Yucatan, is a problem that only further work on the site can elucidate.

Even if this model cannot be applied to Maya east coast trade on evidence presently available, the data from a number of coastal sites suggests another, simpler, descriptive rather than analytical model which may be tested archaeologically. This model (Fig. 5) suggests the existence in the Classic period at least, and possibly both earlier and later, of a long-distance canoe route along the east coast of Yucatan, with major transshipment, chandling or other nodes at Cozumel and in the Bay of Honduras near or at Nito and the mouth of the UIua. Both the existence of the route and the importance of these ports are attested for the 16th century, and they do form natural end-points to an east coast route, though linking to the extended routes round Yucatan to Xicalango in one direction and eastwards to Costa Rica and Panama in the other.

Between these end-points would have been a number of way-stations where the large coasting canoes would put in to off-load and take on goods from the mainland; such stations would habitually be on small islands off the coast, and from their small size and unsuitability for settlement on any substantial scale might well have functioned as de facto ports-of-trade, neutral ground with little other value. We would expect such a way-station to exist near the mouths of each of the major rivers emerging from the hinterland, and to be both small in size and unexpectedly prolific in artifact material, with a larger proportion of exotic goods than a similar small fishing settlement would be able to acquire. The way-station would in turn be reached by river canoe from the major settlements of the hinterland, which, like Lubaantun, often lay near the head of navigation where the river was fordable by overland trails and where goods would have to be offloaded to porters for any journey further inland. Some waystations might be on the coastline itself, which was generally swampy and inaccessible overland; all that would be needed again would be landing facilities for both large and small canoes. One way-station might well 
Figure 1. Selected chemical abundances of obsidian from wild Cane Cay, Ixtepeque and El Chayal. A1T values are in parts-per-mi11ion except the iron abundance, which is in percent. The hatched areas show the root-mean-square deviation in the abundance values. The values in parentheses indicate the number of samples measured.

1st bar - Mean value and root-mean-square deviation for 4 source rocks from Ixtepeque volcano.

2nd bar - Same parameters as 1st bar for 19 obsidian artifacts from Wild Cane Cay.

3rd bar - Same parameters as 1st bar for 4 obsidian artifacts from Wild Cane Cay.

4th bar - Same parameters as 1st bar for 7 obsidian source rocks from a highway cut in the E1 Chayal deposit about $25 \mathrm{~km} \mathrm{NW}$ at Guatemala City. 

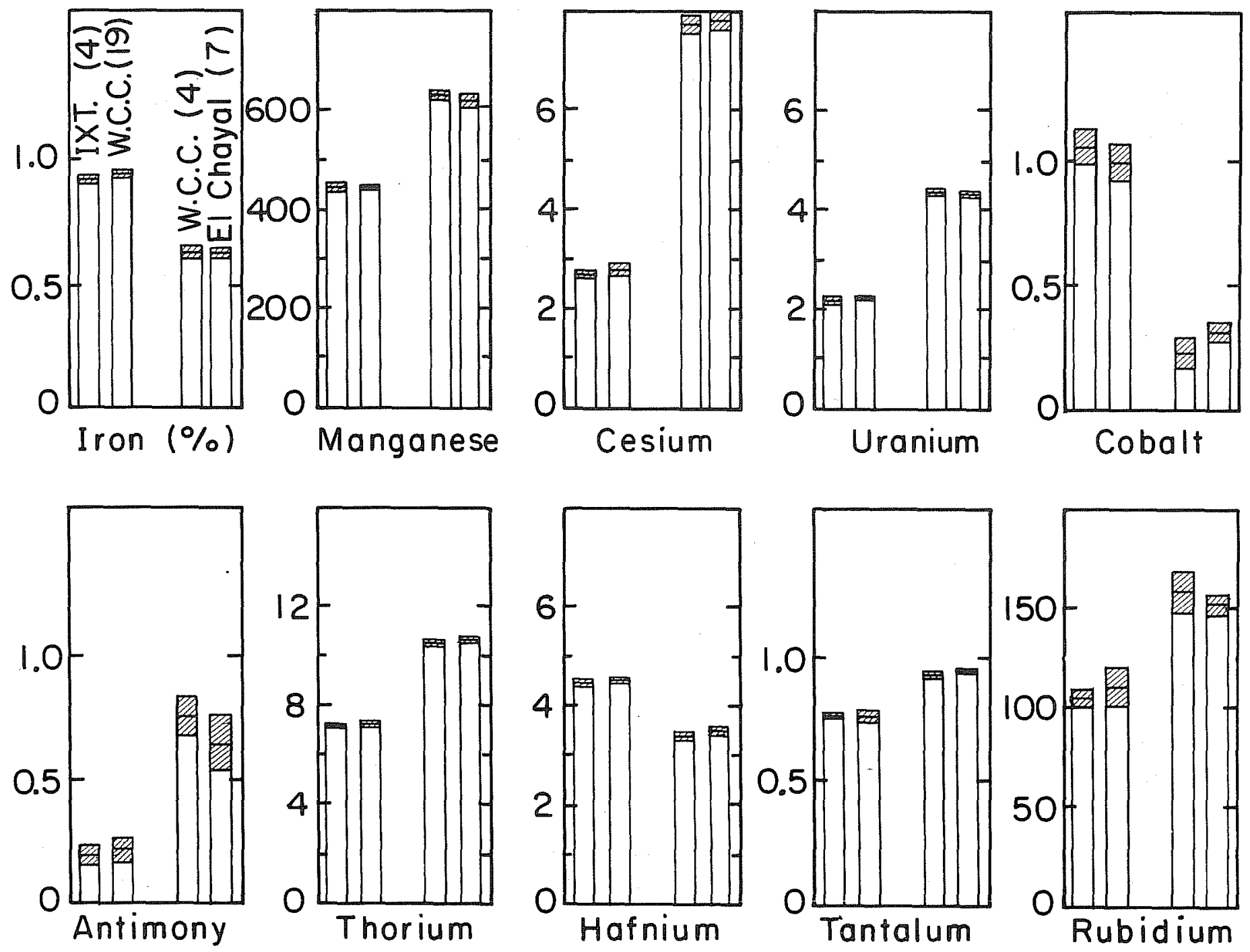

XBL75|I-950I 

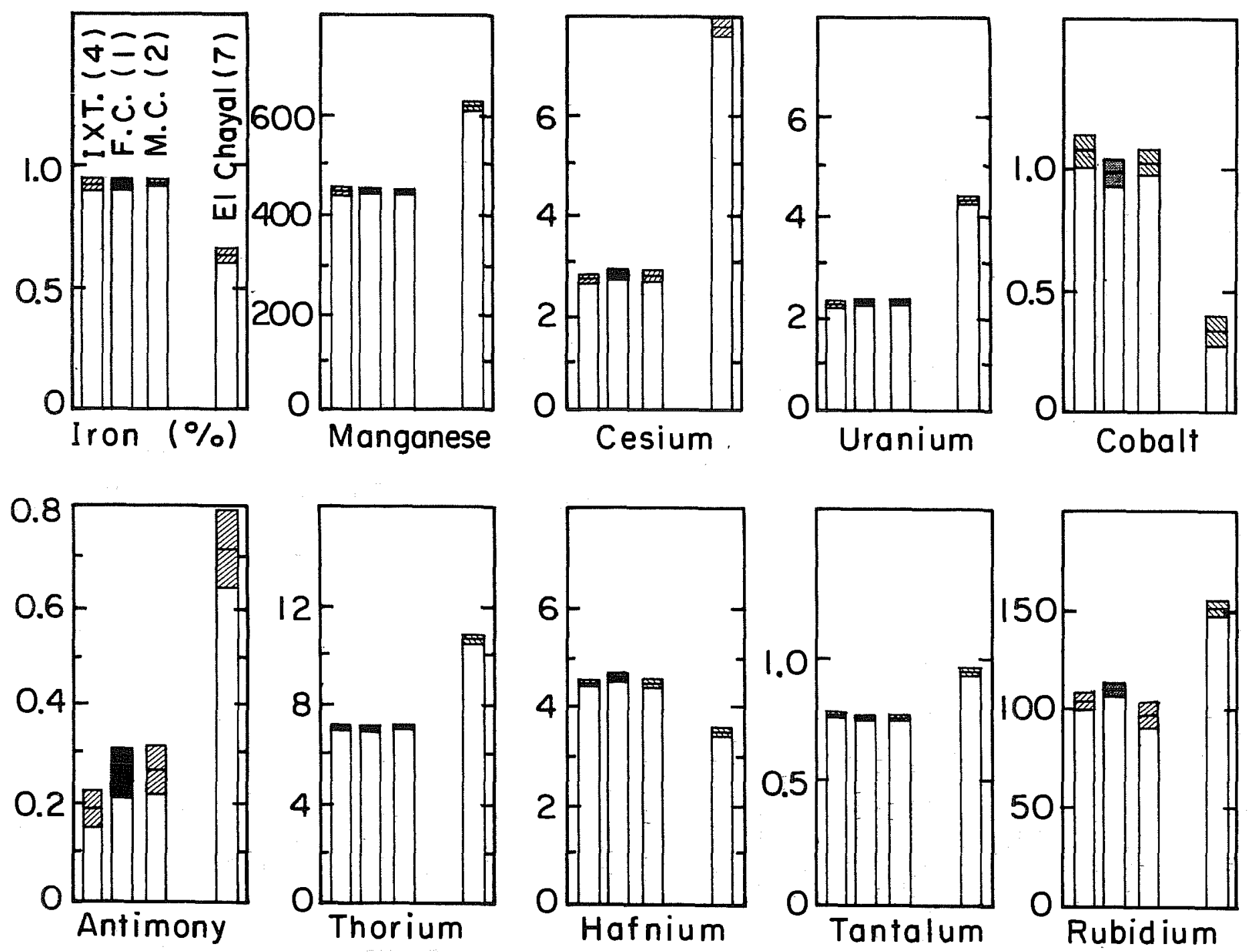

Figure 2. Selected chemical abundances of obsidian from Frenchman's Cay, Moho Cay, Ixtepeque and El Chayal. A11 values are in parts-per-million except the iron abundance, which is in percent. The hatched areas in bars 1 , 3 , and 4 represent the root-mean-square deviation in the abundances. The solid areas on the second bar show the error in a single measurement due to counting statistics. The values in parentheses indicate the number of samples measured. The data for the 1 st and 4 th bars are the same as in Figure 1. 

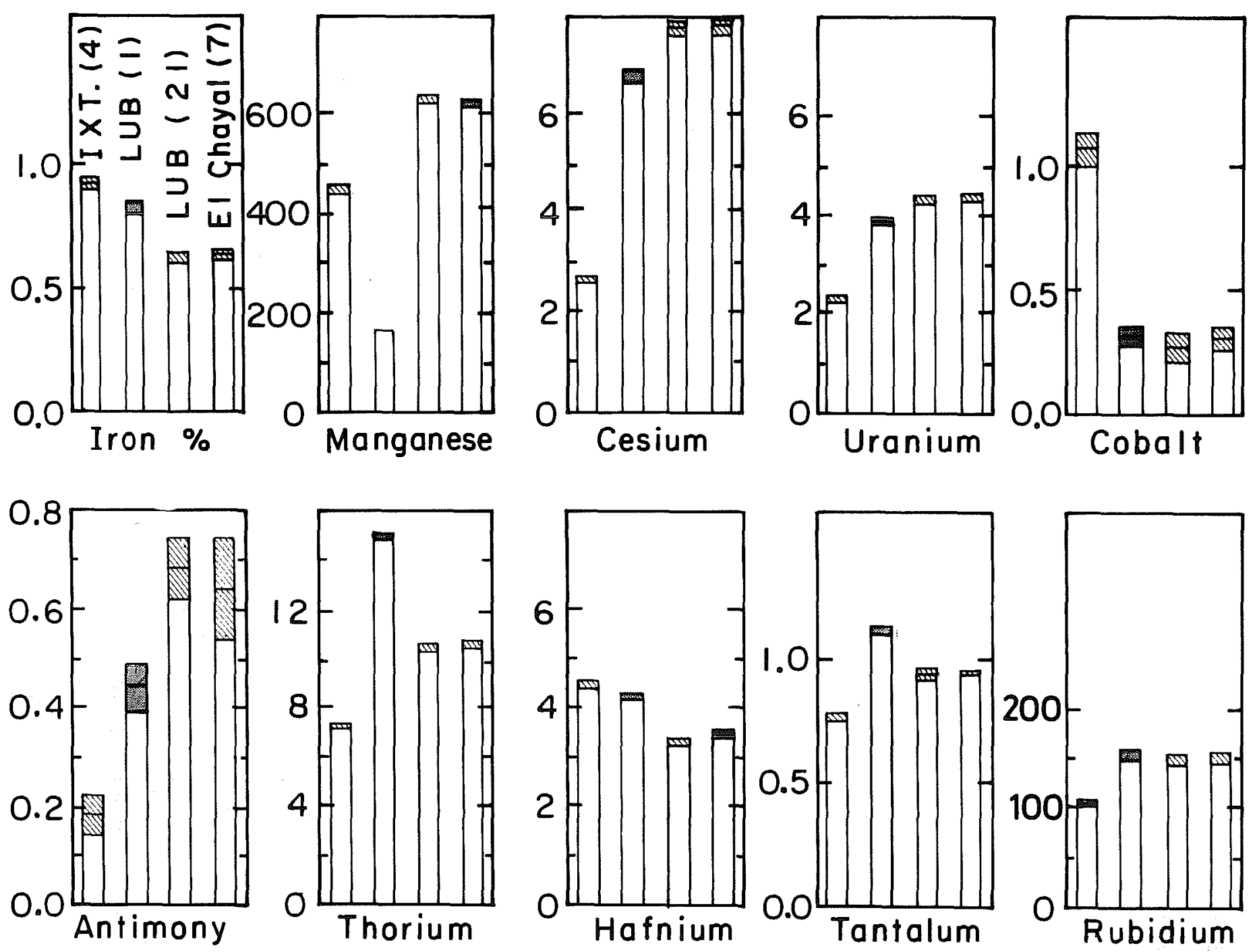

XBL7512-9593

Figure 3. Selected chemical abundances of obsidian from Lubaantun, Ixtepeque and El Chayal. The representation is very similar to Figure 2. 
serve a number of inland centers and a number of river routes: the model advanced suggests some half a dozen stations between Cozumel and the Bay of Honduras, summarized in Fig. 5:

\begin{tabular}{|c|c|c|}
\hline Way-station & River served & Inland center \\
\hline Wild Cane Cay & $\begin{array}{l}\text { Grande } \\
\text { Golden Stream } \\
\text { Deep River } \\
\text { Monkey River }\end{array}$ & $\begin{array}{l}\text { Lubaantun } \\
\text { Nimli Punit } \\
\text { unknown } \\
\text { Quebrada de Oro }\end{array}$ \\
\hline $\begin{array}{l}\text { Tobacco Range or } \\
\text { Kakalche }\end{array}$ & $\begin{array}{l}\text { Mullins River } \\
\text { Stann Creek } \\
\text { Sittee River }\end{array}$ & $\begin{array}{l}\text { unknown } \\
\text { Pomona } \\
\text { Kendal }\end{array}$ \\
\hline Moho Cay & Belize River & Belize Valley generally \\
\hline Marlowe Cay & - & $\begin{array}{l}\text { Altun } \mathrm{Ha} \\
\text { Colha }\end{array}$ \\
\hline Ambergris Cay & $\begin{array}{l}\text { Rio Hondo } \\
\text { Rio Nuevo } \\
\text { Arroyo de Ucum- } \\
\text { Laguna de Bacalar }\end{array}$ & $\begin{array}{l}\text { Nohmul, Ucum } \\
\text { Aventura, San Estevan, } \\
\text { Pozito } \\
\text { Ucum, Tzibanche, Kohunl ich }\end{array}$ \\
\hline Tupak/Chacmool & - & Chichen Itza \\
\hline Tancah & - & Coba \\
\hline
\end{tabular}

Many of these might be disputed: Ambergris Cay (from which Fine Orange and Plumbate pottery have been reported; M. D. Coe, personal communication, 1973) could be replaced by a site such as Santa Rita (which is, however, large, on the mainland proper, and apparently unutilized between the Protoclassic and Postclassic) or Cerro Maya (which seems however to be purely Preclassic in date, reused as a Postclassic pilgrimage center). Neither Marlowe Cay nor Tancah fit the model in being transshipment points from sea-going to river canoes: they are transfers from canoe to porter. The journey from Tupak/Chacmool would only have been a short one across Ascension Bay and then overland, and perhaps a canoe-porter way-station exists within the bay, but the route from here to Chichen Itza is attested in the 16th century, however, improbable it may seem now. The model is, like its predecessor in science, a speculative one: if it fares as well, its progenitor will be well pleased.

\section{ACKNOWLEDGEMENTS}

The obsidian analyses were carried out by $F$. Stross and F. Asaro at the Lawrence Berkeley Laboratory of the University of California at Berkeley; the excavations were sponsored by Cambridge, Harvard and Oxford Universities, the Wenner-Gren Foundation, and the British Museum. 


\section{Obsidian in southern Belize}

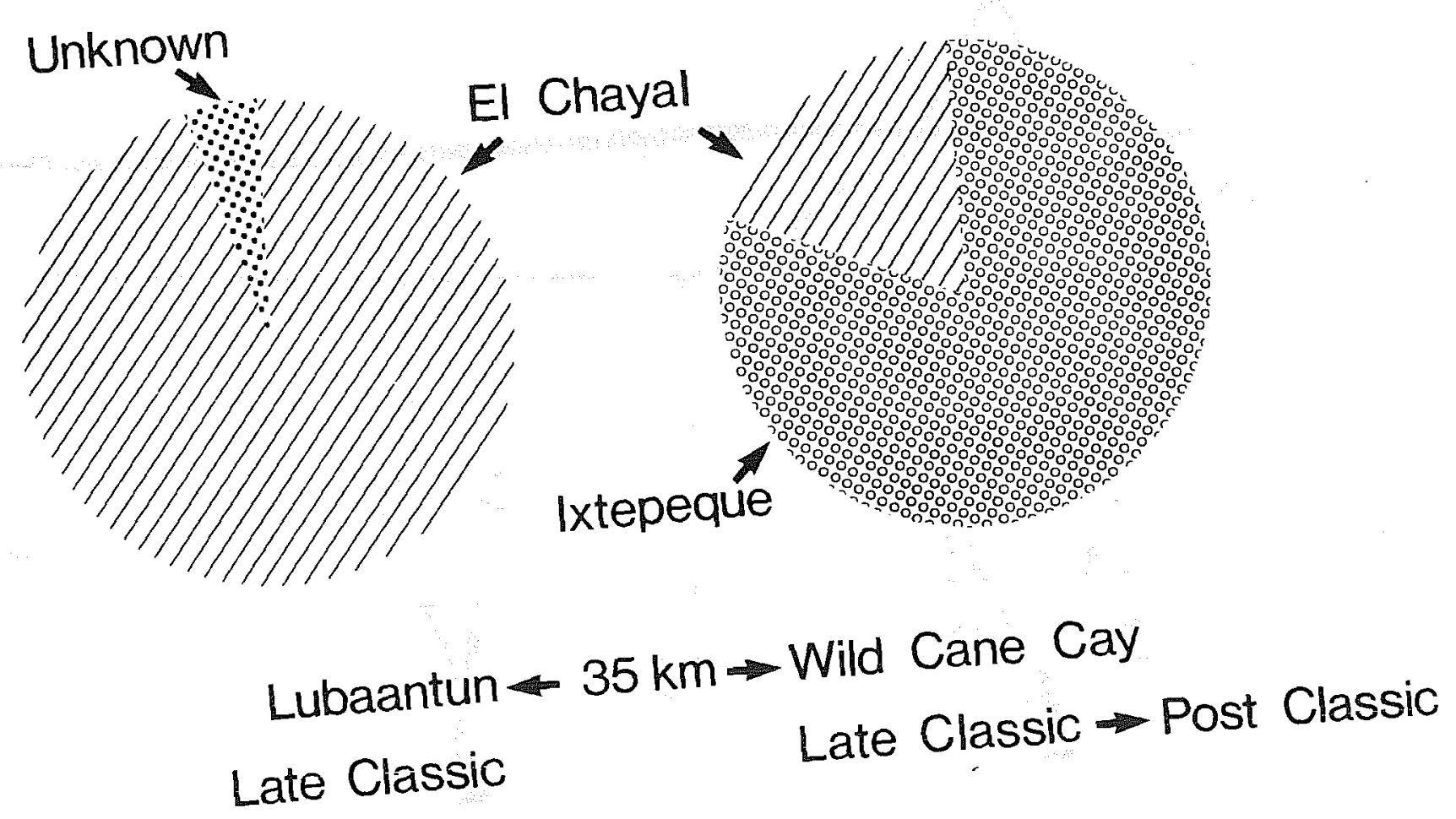

Figure 4 . Obsidian source representation at Lubaantun and
of both may be responsible for the contrasting patterns. 


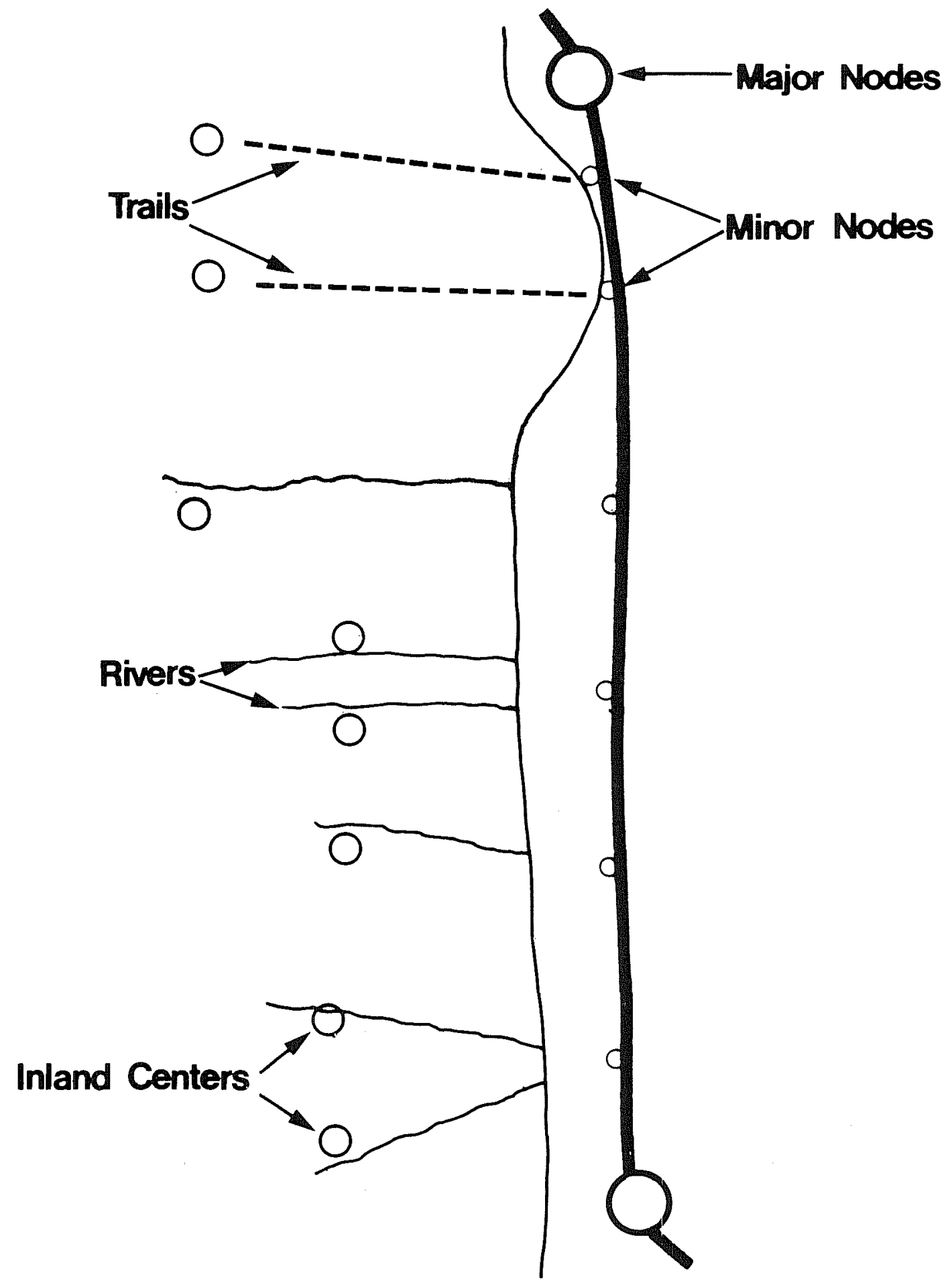

Figure 5. Model for Maya east coast trade. Transshipment from large seagoing canoes to smaller river canoes (in the south) or direct to foot-porters (in the north) would have occurred at minor nodes, which were either small offshore islands or coastal landfalls lacking productive hinterland. 


\section{REFERENCES CITED}

Hammond, N.

1972 Obsidian Trade Routes in the Mayan Area. Science 178: 1092-1093.

* 1975 Lubaantun: A Classic Maya Realm. Monographs of the Peabody Museum, Harvard University 2.

in press An Overland Trade Route Between the Maya Highlands and Lowlands. In: Mesoamerican Routes of Communication and Cultural contact (ed. by T. Lee and C. Navarrete), New World Archaeological Foundation, Provo.

Sabloff, J. A. and W. L. Rathje

1975 Changing Precolumbian Commercial Patterns. Monographs of the Peabody Museum, Harvard University 3.

Sidrys, R., J. Andresen, and D. Marcucci

1976 Obsidian Sources in the Maya Area. Journal of New world Archaeology 1(5):1-13. 
LONG DISTANCE OBSIDIAN TRADE:

NEW DATA FROM THE WESTERN MAYA PERIPHERY

Jay K. Johnson

Obsidian trace element analysis constituted a major portion of a recently completed studyl of chipped stone artifacts from 27 archaeological sites in the region surrounding the Classic Maya site of Palenque in southern Mexico (Fig. 1). Palenque's location on the western margin of the southern Maya lowlands, between that area and the highland Mexican obsidian sources, provides a ready gauge of the relative integration of long distance Maya trade in obsidian. In order to explore the possibilities of alternative trade routes a total of 173 specimens, constituting a $20 \%$ stratified random sample from all site collections in the study area, was subjected to X-ray fluorescence analysis.

In 1972 Hammond proposed a model for Maya obsidian trade based on the results of the trace element analysis of obsidian from $23 \mathrm{Classic}$ Maya sites. Obsidian from these sites has been related to two major highland sources in Guatemala. Arguing from the geographical distribution of obsidians traced to these sources, topographic considerations, and ethnohistoric data, Hammond (1972: Fig. 1) hypothesized two distinct trade routes. Obsidian from the El Chayal source near Guatemala City was traded down the Rio Chixoy to Altar de Sacrificios. From there it was traded up the Rio de la Pasion to Seibal and down the Usumacinta to Piedras Negras. Obsidian from the Ixtepeque source southeast of El Chayal was traded to Copan and thence down the Rio Montagua to the Gulf of Honduras. It was then distributed along the coast of the Yucatan Peninsula to sites in Belize and the northern Maya lowlands. Sites in the Peten received obsidian from both sources.

Unfortunately, the data base upon which Hammond built this reconstruction is quite smal1, consisting of 34 specimens from 23 sites (Stross et al. 1968: Table 2; Stross et al. 1971: Table 15.4). The largest single site sample is eight artifacts from Tikal. Most of the sites are represented by a single analyzed specimen. This problem of sample size was pointed out almost immediately by the publication of the analysis of 14 additional specimens from Seibal (Graham, Hester, and Jack 1972). Whereas Hammond was able to place Seibal in an exclusive El Chayal exchange network, these 14 specimens included obsidian from three other source areas in addition to E1 Chayal. The most damaging source allocation in terms of the Hammond model was the occurrence of an Ixtepeque obsidian at Seibal. This weakens the argument that the Chixoy, Pasion and Usumacinta drainages were completely dominated by the El Chayal source area trade.

Further modification of the Hammond model is necessitated by the discovery of a new obsidian source serving the Maya lowlands. Six of the obsidians analyzed from Seibal are probably from the San Martin Jilotepeque source area. Probable San Martin obsidian, also known as Aldea Chatalun (Graham, Hester, and Jack 1972:111), has been identified in the much 


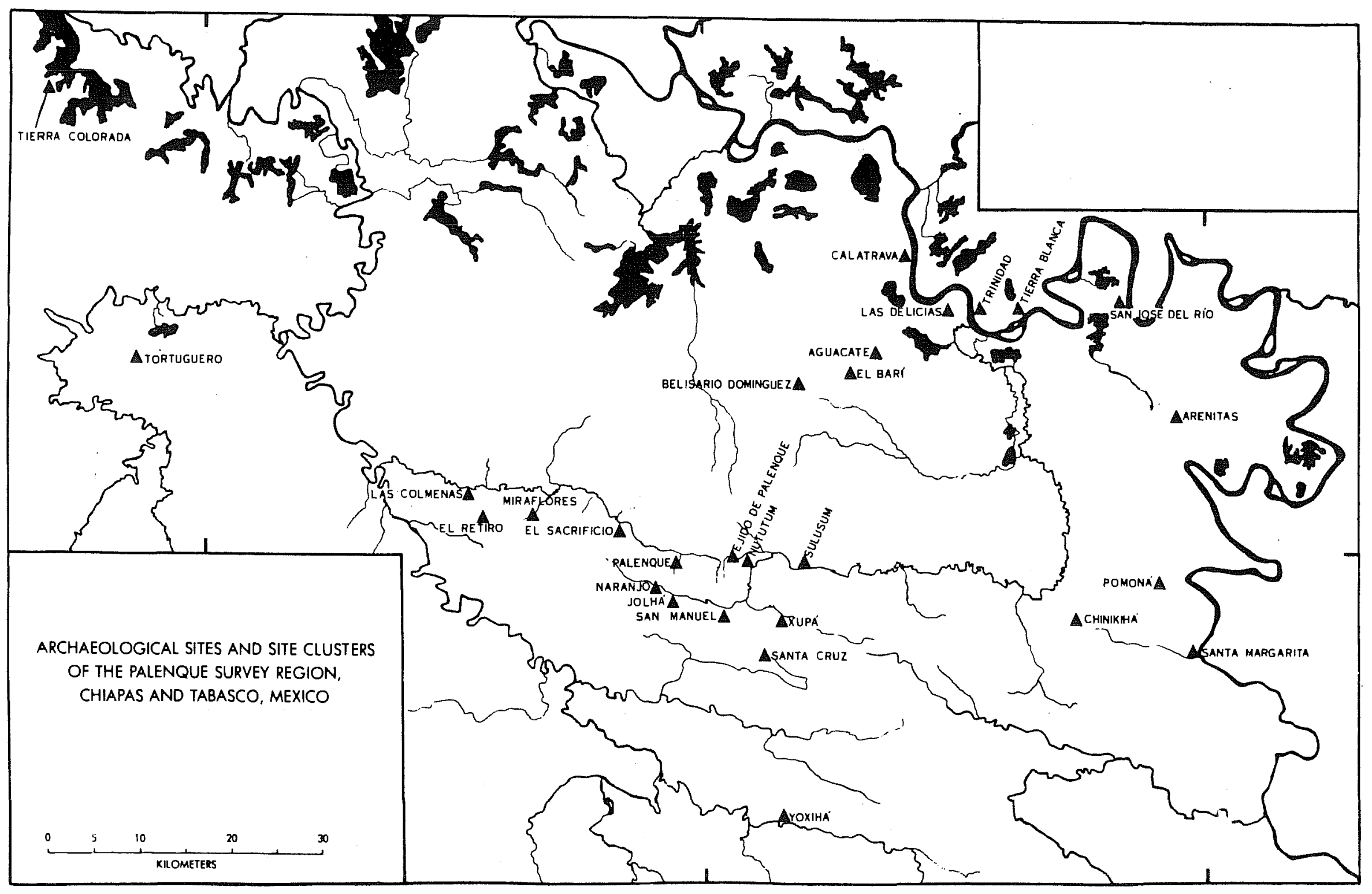

Figure 1. Location of sites in the Palenque region, southern Mexico. 
enTarged sample recently reported for Tikal (Moholy-Nagy 1974: Table 1).

How does the Palenque region obsidian source data fit with the Hammond model? Hammond (1972:1093) concluded his discussion with a statement of test implications, "if the model is true, then obsidian from an Usumacinta Basin.site, for example, Palenque, should come from El Chayal...." Prior to the beginning of the Palenque analysis an alternative hypothesis was built on the strength of Thompson's (1964:19) assessment of the importance of coastal Yucatan trade routes. If the rapids below Piedras Negras (Satterthwaite 1943:8-9) truncated the El Chayal-Chixoy-Usumacinta trade route, then the Palenque region may have been supplied by sea routes and obsidian from Ixtepeque should be found.

As it turns out, both expectations were fulfilled. While the majority of the Palenque region obsidian (94\%) is from El Chayal, there are specimens from Ixtepeque as well as San Martin, possibly Zaragosa, and one piece of green obsidian (Table 1).

The green obsidian offers a useful key to understanding obsidian exchange in the Western Maya Periphery. The fact that it occurs exclusively at Yoxiha, on the southern Timit of the survey area, suggests that rather than being traded directly from its probable Mexican source location, it may have been derived from a redistributive center in highland Guatema 1a, Kaminaljuyu perhaps. This is supported by the report of green obsidian from Piedras Negras (Coe 1959:13) and Tonina (Sheets 1975:7) and its reported absence at Comalcalco (Peniche Rivero 1973:156), a Maya center northwest of Palenque and even closer to the Pachuca source locality.

The occurrence of green obsidian at Yoxiha has been combined with the relative importance of San Martin source specimens at the site to hypothesize a second obsidian procurement system, independent from the Palenque system (Johnson n.d.). Assuming for the sake of discussion that this pattern could withstand more extensive sampling, the location of the Yoxiha trade sphere, inland from the Gulf coast, would seem to point to an overland route of trade. This would explain the inclusion of the San Martin Jilotepeque obsidian in a primarily El Chayal trade network. The San Martin source area is located west of El Chayal, between that source and Yoxiha.

If Palenque participated in a separate obsidian procurement system, it is characterized by the absence of green obsidian, the rarity of San Martin obsidian, and the unique occurrences of the Zaragosa and Ixtepeque obsidians. El Chayal is still the predominant source represented. The most straightforward model would have obsidian from the three Guatemalan sources and the redistributed green obsidian being traded down the Usumacinta toward Palenque. The lack of green obsidian and rarity of San Martin could then be attributed to a fall-off of the minority types. As obsidian was traded downstream, the rare types became less and less frequent unti1, in the case of the green obsidian, they fell out of the system entirely. However, if this were the case, we would expect to 
find Ixtepeque obsidian at Yoxiha in greater abundance than at Palenque. In fact, Ixtepeque was not one of the source areas represented in the Yoxiha sample.

The Ixtepeque obsidian at Palenque seems to point to a coastal trade route. Ixtepeque as well as El Chayal obsidian could have been transported via the Rio Motagua to the Gulf of Honduras and from there around the Yucatan Peninsula and up the Usumacinta to Palenque. The fact that El Chayal and Ixtepeque were important sources at the Gulf coast site of San Lorenzo (Cobean et al. 1971: Table 2) points to the possibility of this sea route having considerable time depth. The only Guatemalan obsidian reported from the contemporaneous Veracruz site of La Venta (Jack, Hester, and Heizer 1972: Table 1) is San Martin. This weakens the argument somewhat.

More critical to the proposal that Palenque was participating in an exclusively coastal trade in obsidian is the source area composition of obsidian collections from the coast of Belize. In a recently completed analysis, Hammond (this volume) found El Chayal to be a minority source in this area with Ixtepeque predominating. This reversal of the relative importance of the two source areas points to the Tikelihood that El Chayal obsidian was not being traded around the Yucatan Peninsula and up the Usumacinta River to Palenque. Obsidian from this source probably reached the Western Periphery by means of an interior riverine route, traveling down the Chixoy and Usumacinta Rivers.

On the other hand, Ixtepeque obsidian has not been discovered in any of the collections from sites south of Palenque on the Usumacinta drainage. It is not until Seibal on the middle Pasion that it has been reported. Although the sample size is small, present evidence seems to indicate that while the majority of the Palenque area obsidian came from El Chayal via interior routes, the Ixtepeque obsidian came around or possibiy across the Yucatan Peninsula to the Gulf coast and up the Usumacinta River.

Graham, Hester, and Jack (1972) found indications of a shift in the importance of the various obsidian sources through time in the sample from Seibal. Unfortunately, most of the non-El Chayal obsidians in the trace element sample from the Palenque region were not associated with sufficiently restricted ceramic assemblages to allow an assessment of temporal change in trade relationships.

The probable Zaragosa obsidian proved to be a partial exception. One of the four specimens came from a terminal Late Classic deposit. Associated ceramics include Early and Late Balunte types. A second probable Zaragosa obsidian was dated as generalized Late Classic, and the other two are unassigned as to period.

This in itself is not a particularly convincing pattern. However, all of the specimens which were designated as probable Zaragosa on the basis of their trace element composition proved to be a distinctive opaque black obsidian. Additionally, none of the obsidian allocated to the other source areas was visually similar. On the strength of these facts, the ceramic 
associations of the eight unanalyzed black obsidians in the Palenque collection were examined. Two of these are Early and/or Late Balunte, two are Early Balunte, and the rest are either Late Classic or unassigned. Once again a terminal Late Classic time level is indicated.

The occurrence of these probable Zaragosa obsidians on a late time level at Palenque precedes only slightly their Bayal phase dating at Seibal (Graham, Hester, and Jack 1972:113). The Zaragosa source area is located in Puebla, and nearby sites in Veracruz, Cempoala, Quiahuitzlan and El Tajin, have shown a heavy dependence on this source (Jack, Hester, and Heizer 1972).

The use of the Zaragosa source at El Tajin has interesting implications. Ruz L. $(1952: 50,58)$ reports a complex of artifacts which may relate to this area which was recovered from superficial deposits in the Palace at Palenque. This complex includes votive axes, stone yokes and tecalli vesse1s. Ruz L. (1952:65) related these artifacts to a proposed Totonac invasion which led to the collapse of Palenque. Although succeeding years of research have not confirmed this hypothesis, these artifacts certainly indicate some sort of contact between Palenque and the coastal plain at the end of the Late Classic. The Zaragosa obsidian at Seibal takes on added interest in this 7 ight, for surface finds at that site include a votive axe (Willey et al. 1975:45).

\section{NOTES}

1. This paper is based on a portion of my dissertation research (Johnson 1976) which is one aspect of a comprehensive study of trade in the Palenque region. As such, I must express my debt to Robert L. Rands, director of my dissertation and the Palenque area research. Both he and Ronald L. Bishop have made useful suggestions in all stages of work which led to this paper. I would also like to thank Ray Sidrys for providing the Guatemalan source area obsidian samples used in the trace element analysis. The Department of Anthropology, Graduate School and Graduate Student Council at Southern I17ino is University were generous in supplying the travel funds which allowed me to attend the Belize lithics conference. 


\section{TABLE I}

The Distribution of Non-El Chayal Obsidian in

Palenque Region Trace Element

Analys is Sample

\begin{tabular}{lccc}
\hline Site & Ixtepeque & $\begin{array}{c}\text { Source Allocation } \\
\text { San Martin }\end{array}$ & \\
& & & \\
\hline Palenque & 2 & 1 & 4 \\
$\%$ of site total & $1.5 \%$ & $0.8 \%$ & $3 \%$ \\
Calatraba & 1 & \\
$\%$ of site total & $50 \%$ & \\
Yoxiha & 2 & \\
$\%$ of site total & $20 \%$ & \\
\hline
\end{tabular}

*Allocation based on resemblance to published data; source samples from Zaragosa not available for reanalysis. 


\section{REFERENCES CITED}

Cobean, R. H., M. D. Coe, E. A. Perry, Jr., K. K. Turekian, and D. P. Kharkar

1971 Obsidian Trade at San Lorenzo Tenochtitlan, Mexico. Science 174:666-671.

Coe, W. R.

1959 Piedras Negras Archaeology: Artifacts, Caches, and Burials. Museum Monographs. The University Museum, Philadelphia.

Graham, J. A., T. R. Hester, and R. N. Jack

1972 Sources for the Obsidian at the Ruins of Seibal, Peten, Guatemala. Contributions of the University of California Archaeological Research Facility 16:111-116.

Hammond, $N$.

1972 Obsidian Trade Routes in the Maya Area. Science 178:10921094.

Jack, R. N., T. R. Hester, and R. F. Heizer

1972 Geological Sources of Archaeological Obsidian from Sites in Northern and Central Veracruz, Mexico. Contributions of the University of California Archaeological Research Facility 16:117-122.

Johnson, J. K.

1976 Chipped Stone Artifacts from the Western Maya Periphery. Dissertation, Southern Illinois University at Carbondale. University Microfilms, Ann Arbor.

n.d. Site Hierarchy in the Western Maya Periphery, a Correlation of Lithic Epigraphic, Architectural and Ceramic Data. In: J. Charles Kelley Festschrift, University Museum and Art Galleries, Southern Illinois University at Carbondale (in press).

Moholy-Nagy, H.

1974 Obsidian at Tikal, Guatemala. Actas del XLI Congreso Internacional de Americanistas $I: 511-518$.

Peniche Rivero, C.

1973 Comalcalco, Tabasco: Su Ceramica, Artefactos y Enterramientos. M.A. Thesis, University of Yucatan, Merida. 
Ruz L., A.

1952 Exploraciones en Palenque: 1951. Anales del Instituto Nacional de Antropologia e Historia 5:47-65.

Satterthwaite, L.

1943 Introduction, Piedras Negras Archaeology: Architecture, Part 1, No. 1. University Museum, Philadelphia.

Sheets, P. D.

1975 New World Lithic Analys is Symposium: Southern Mesoamerica. Paper given at 40th Annual Meeting of the Society for American Archaeology, Dallas.

Stross, F. H., D. F. Stevenson, J. R. Weaver, and G. Wyld

1971 Analysis of American Obsidians by X-ray Fluorescence and Neutron Activation Analysis. In: Science and Archaeology (ed. by R. Bri11):210-221. MIT Press, Cambridge.

Stross, F. H., J. R. Weaver, G. Wyld, R. F. Heizer, and J. A. Graham

1968 Analysis of American Obsidians by X-ray Fluorescence and Neutron Activation Analysis. Contributions of the University of California Archaeological Research Facility $5: 59-79$.

Thompson, J. E. S.

1964 Trade Relations Between the Maya Highlands and Lowlands. Estudios de Cultura Maya 4:13-49.

Willey, G. R., A. L. Smith, G. Tourtellot, III, and I. Graham

1975 Excavations at Seibal: Introduction: The Site and Its Setting. Memoirs of the Peabody Museum of Archaeology and Ethnology, Harvard University 13(1). 
SPATIAL DISTRIBUTION OF FLINT AND OBSIDIAN ARTIFACTS AT

TIKAL, GUATEMALA

Hattula Moholy-Nagy

INTRODUCTION

Larger lowland Maya sites are characterized by architectural heterogeneity and the clustering of structures around plazas to form definable groups (Bul7ard 1960; Becker 1973). Yet in spite of the fact that archaeological excavations typically are oriented towards particular structures or structure groups, most Maya area artifactual studies tend to ignore intrasite provenience.

Provenience-oriented studies have produced very interesting results, for example, at Teotihuacan (Spence 1974) and in the United States Southwest (Hil1 1968; Longacre 1968). But to date only a few such artifact studies have been undertaken in the lowland Maya area. Becker (1973) and Haviland (1974) have studied the association of material culture with site provenience and produced evidence of occupational specialization at Tikal. Haviland (Tikal Report No. 20; personal communication) is studying the artifacts associated with residential groups in an attempt to learn what activities took place in such groups, to try to identify a basic household inventory of tools, and to get data for the reconstruction of kinship organization. Stoltman (1975) has analyzed flint and obsidian artifacts from inside and outside the fortifications at Becan and has found evidence for functional differences between different parts of the site.

\section{A TRIAL ANALYSIS}

An analysis was undertaken of the flint and obsidian artifacts associated with different kinds of structures and groups excavated at Tikal. One objective was to see if the artifact distributions correlated in any way with the structural types, whether different kinds of loci might have distinctive artifact "profiles". Another objective was to see if the artifacts indicated anything about ancient activities associated with various loci.

The artifact classification used was based loosely on Kidder's (1947) for Uaxactun. A preliminary classification of structures and groups was formulated for the purposes of this analysis. It grew out of one formulated by Haviland for his study of Tikal burials in which he used architectural form, structure and group size, construction methods, and associated monuments, chultuns, and special deposits as distinguishing criteria. Functional terms were successfully avoided except in the case of "temple", where no satisfactory substitute could be found.

The preliminary classification includes (Fig. 1):

1. Temple Groups, such as the North Acropol is

2. Twin-Pyramid Groups, of which nine are known at Tikal 
3. Range Structure (RS) Groups, such as the Central Acropolis

4. Intermediate Structure Groups (ISGs)

5. Smaller Structure Groups (SSGs)

It is here assumed that groups of structures indicate some kind of ancient functional unity.

From the criteria mentioned above, it was hypothesized that the Temple and Twin-Pyramid Groups were ceremonial in function (Coe 1967:41-50; Jones 1969). Some Range Structures may have been el ite residences (Harrison 1970). Others such as those associated with Twin-Pyramid Groups, were evidently not residential. Intermediate Structure Groups (Becker 1971, 1973) and Smaller Structure Groups (Haviland 1963, 1974, Tikal Report No. 20) were mainiy residential. Presumabiy the occupants of the ISGs ranked lower than those of the RSGs, but enjoyed a higher social status than the occupants of the SSGs.

Eleven loci were selected from the approximately 690 architectural groups (Becker 1973:397-398) identified at Tikal to date. These represented types in the five-part classification given above. The sample was composed of one Temple Group, the North Acropol is; one Twin-Pyramid Group, Group 4E-4; three Range Structures, Structures 4E-31, 5D-15; and 5D-46; three Intermediate Structure Groups, Groups $7 \mathrm{~F}-1,4 \mathrm{H}-1$, and $6 \mathrm{E}-2$; and three Smaller Structure Groups, Groups 4F-2, 6E-1, and 2G-1. The first column on Table 1 gives figures for Central Tikal as a whole.

Range Structures rather than RSGs were selected because of the more manageable sample size. Haviland, the excavator of RS 4E-31, feels it was not a residence (Tikal Report No. 21). I feel that present evidence suggests it had the same function as the other two RSs in the sample, 5D-15 and 5D-46, and that this function probably was residential.

For this trial analysis, proveniences were chosen primarily for size of excavated sample rather than representativeness of Tikal as a whole. Therefore, all pertain to the 16-square-kilometer Central Tikal Area (Fig. 1 ; Carr and Hazard 1961). The reason for choosing 1 arge individual samp ies was that results could be presented in terms of percentages and ratios. Another consideration in selecting loci was approximate equivalence in time. Al1 were in use during the Late Classic Period and most of them had their heaviest occupation at that time. Artifacts from Terminal Classic Period lots (Eznab ceramic complex) were not included in the analysis. Because artifacts found in construction fill may be mixed, not only in date but very $7 i k e l y$ also in provenience, artifacts from those lots designated as construction fill by the excavators were also omitted. Concentrating upon artifacts from undisturbed occupation debris would undoubtedly have been less complicated and would have given better results, but at this stage of analysis of Tikal materials, this information is not yet available for most loci. Archaeological context was broadly divided into special deposits (burials, caches, and deposits of problematical nature) and general excavations (a11 other contexts except construction fi11). This distinction is important in that material found in general excavations would have been available to the users of a particular locus, while material in special deposits on the whole would not have been. 
Flint and obsidian artifacts from each locus were analyzed with regard to each other, that is, in terms of percentage of the locus total or in proportion of occurrence to each other. There were two reasons for this: to try to measure the relative importance of artifacts and kinds of stone and, especially, because no other satisfactory yardstick was available. In a recent paper, Sidrys (1974) raised objections to comparing artifacts with each other. I feel they are well taken, but that it is possible to mitigate all of them by careful excavation and detailed reporting. On the other hand, Sidrys' suggested standard, volume of excavation, is very difficult to calculate (except in those rare cases where the artifact analyst and the excavator are the same person), does not take into account the differing abilities of excavators to recover materials (suggested by $\mathrm{N}$. Hammond), and leaves surface finds in 1 imbo (Johnson 1976).

The figures on Table 7 are preliminary in that not a 71 have been checked against the lot cards, which list all materials found in a given excavation. Therefore, they may differ from figures given by other Tikal authors or from those to be published in the final Tikal artifact report.

A comment on terminology also seems in order here. Researchers working with Maya stone artifacts do not yet have a general1y agreed upon terminology, either for kind of stone or for artifact type. Therefore, for want of anything better, I have continued to use most of A. V. Kidder's (1947) functional terms here. "Pebble/core choppers" is modified from Willey (Willey et al. 1965:438-440, Fig. 277, $i, j$ ). "Point-knife" is a contraction of "projectile point or $\mathrm{knife"} \mathrm{and} \mathrm{is} \mathrm{taken} \mathrm{from} \mathrm{Spence} \mathrm{and}$ Wiegand (1968). Non-functional terms have been used for some types which did not occur at Uaxactun or which were not recognized there. These are ultimately derived from a classification formulated by Karl G. Heider for Tikal artifacts in 1960.

\section{RESULTS AND COMMENTS}

The results of this trial analysis are summarized in Table 1 . Some of them, along with additional comments on Tikal flint and obsidian, are discussed here.

Artifacts were classified into three broad material categories: local flint, imported flint, and obsidian. Of interest is the circumstance that over $83.9 \%$ of al1 obsidian recovered from Central Tikal came from special deposits. Yet it was also present.at all of the analyzed loci, where it comprised from 5.6 to $42.9 \%$ of all the chipped stone artifacts from general excavations alone. This suggests that during the Classic it was probably widely distributed throughout Central Tikal. However, the two loci wi th the lowest relative amount of obsidian, SSG 2G-1 and ISG $4 \mathrm{H}-1$, were also the two loci farthest away from the Great Plaza-North Acropolis center.

In an initial analysis which included both Eznab deposits and construction fill, green obsidian was widely distributed. It occurred at a11 loci except SSG $2 \mathrm{G}-1$, and comprised between $0.2 \%$ and $8.1 \%$ of the total obsidian. 
Figure 1. Map of Tikal

1. North Acropol is

2. Twin-Pyramid Group 4E-4

3. Range Structure 4E-31

4. Range Structure 5D-15

5. Range Structure $5 D-46$

6. Intermediate Structure Group 7F-1

7. Intermediate Structure Group 4H-1

8. Intermediate Structure Group 6E-2

9. Sma11er Structure Group 4F-2

10. Smal1er Structure Group 6E-1

11. Smaller Structure Group 2G-1 


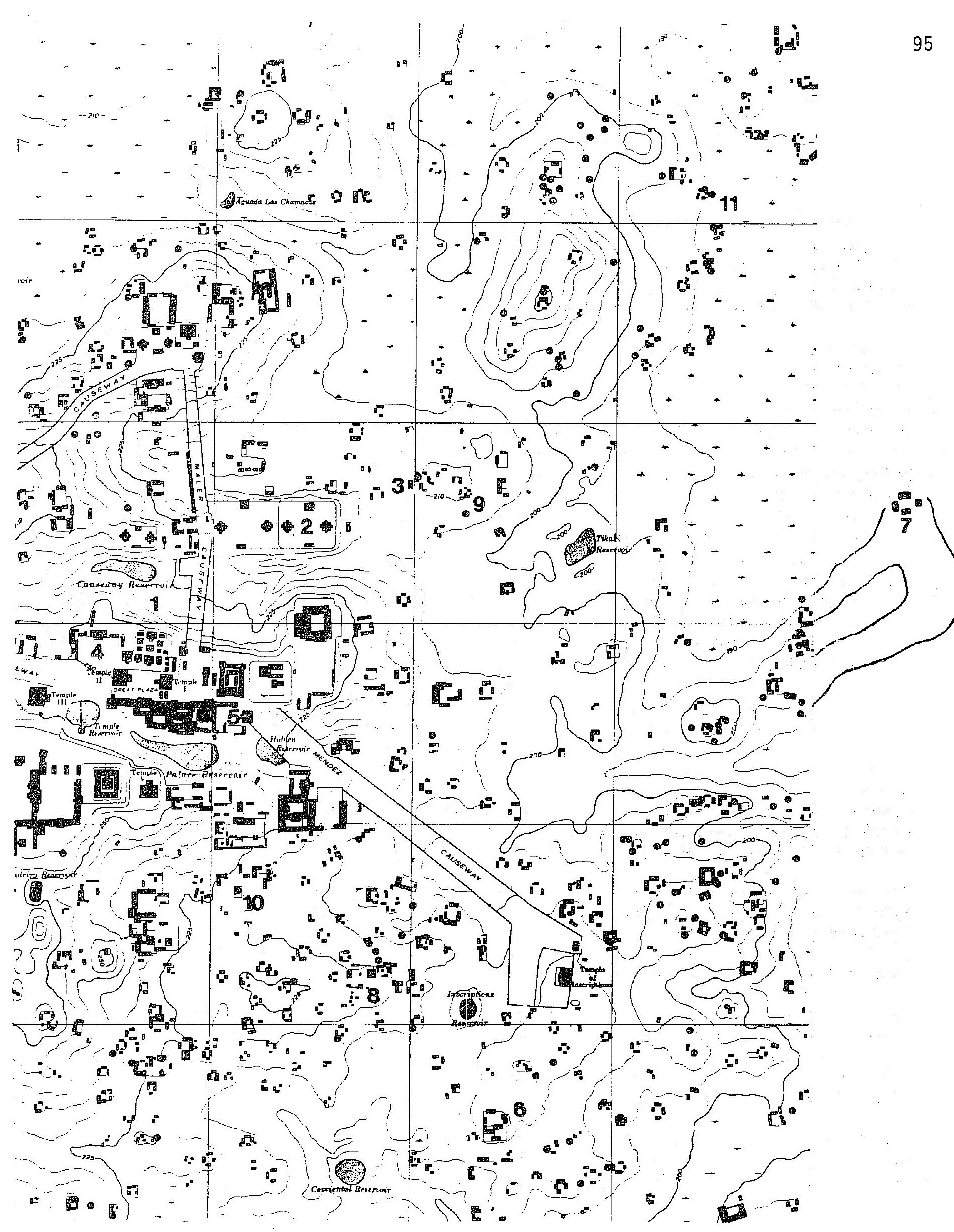


Eliminating Eznab deposits and construction fill greatly reduced the green obsidian sample. It no longer appeared among the artifacts from RS 4E-31, RS 5D-15, ISG 4H-1, and SSG 6E-1, where its occurrence had been restricted to construction fill. As suggested previously (MoholyNagy 1975), the distribution of green obsidian at Tikal seems more influenced by time--with a maximum use in the Early classic--than by social status. Furthermore, even after green obsidian began to be imported in quantity sometime during the Early Classic, grey obsidian was still preferred for special deposits.

In the absence of any other identified Mesoamerican source, green obsidian found in Maya lowland sites is generally assumed to have come from the Central Mexican source near Pachuca, Hidalgo (cf. Sheets 1975). A11 grey obsidian identified from Tikal to date came from highland Guatemalan sources (Moholy-Nagy 1975: Table 1). However, Pires-Ferreira (1975:30) mentions a green obidian of unknown source but possibly from 0axaca, and a few of the green obsidian samples from Tikal could not be identified as to source. Although it is possible that this unknown green obsidian source could be a product of analytical procedures, it might be well to regard green obsidian more critically. I also suspect on chronological and typological grounds (cf. Tolstoy 1971: Figs. 2 and 3) that most, if not a11, of the stemmed grey and green obsidian point-knives found at Tikal and elsewhere in the Maya lowlands came ready-made from the Mexican highlands. In spite of many years of analyzing for obsidian source, apparently no data yet exist for secondarily worked artifact types such as point-knives, eccentrics, or incised obsidians. Hopefully, this gap in knowledge can be filled soon.

Two kinds of imported, fine-textured flint can be readily distinguished at Tikal. Of minor importance is a banded tan flint, which may have been imported only in the form of daggers (Coe 1957) during the Late Preclassic. of more common occurrence during the Classic Period is an unbanded tan, brown, or dark brown flint, which occurs primarily as point-knives, and occasionally as eccentrics, flakes, and nodules. Superficially, both kinds of flint appear identical to nodules from the site of Colha, near Orange Walk, Belize (Wilk 1976:152-173).

RSs had the highest percentage of imported flint--never more than $3.6 \%$ with ISGs next, and SSGs with the lowest. The amount of imported flint is directly related to the number of point-knives recovered from the particular locus. The exception is the North Acropolis, where imported flint occurred primarily in the form of eccentrics.

The materials found in general excavations are here considered as having been, available to all of the occupants or users of a locus. Therefore, the counts from general excavations have been given more emphas is on Table 1. These counts do show some correlations and lack of correlation with group or structure type.

Regarding artifact types, generally RSs and ISGs produced higher percentages of bifacially worked artifacts than SSGs. RSs had slightly more pointknives than ISGs, and ISGs had noticeably more than SSGs. Point-knives may 
TABLE 1. FLINT AND OBSIDIAN ARTIFACT COMPARISONS

Local flint \%

Imported

Unstudied

A11 flint:Gn Ex \% Sp Dp \%

Loc flint:Gn Ex $\%$ Sp Dp \%

Imp flint:Gn Ex \% Sp Dp \%

Grey obsidian \% Green obsidian \% Red/Black obs. no.

A11 obsidian:Gn Ex \% Sp Dp \%

Grey obs:Gn Ex \% Sp Dp \%

Green obs:Gn Ex \% Sp Dp \%

Obs:F1 int-Tota 1

-Gn Ex \%

-Sp Dp $\%$

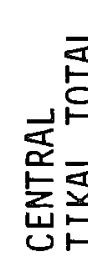

点

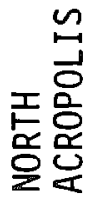

99.3

0.6

0.1

52.3

(47.7)

52.0

$(48.0)$

86.5

(13.5)

$(99.0)$

17.0

$(83.0)$

16.1

(83.9)

69.6

30.4

(1.5)

4.5

$(0.8)$

1.1
1.0
8

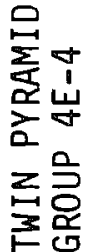

\begin{tabular}{|l|l}
99.5 & 99.4
\end{tabular}

99.4
0.6

$-$

\begin{tabular}{l|lll}
90.0 & 100.0 & 97.3 & 36.1
\end{tabular}

10.0

90.6

9.4

100.0

3.4
$(96.6)$

99.5 ${ }^{0.5}$

(98.9)

10.0 $(90.0)$

30.0
70.0
$(0.5)$
2.7
$(0.5)$

RANGE STRUCTURES

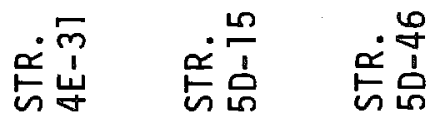

$96.4 \quad 96.4 \quad 97.5$

$3.6 \quad 3.6 \quad 2.5$

$\begin{array}{ll}- & 2.7 \quad 63.9\end{array}$

$\begin{array}{lll}100.0 & 97.2 & 34.5\end{array}$

$100.0 \quad 97.265 .5$
$-\quad 2.865 .5$

$\begin{array}{lll}100.0 & 100.0 \quad 100.0\end{array}$

99.3

0.7

19.6

80.4

18.9

81.9

100.0

1.3

6.0

0.2

$\begin{array}{lrr}100.0 \quad 2.1 & 57.9\end{array}$

\begin{tabular}{l}
$-\quad 97.944 .7$ \\
\hline
\end{tabular}

- $\quad-100$.
() - incomplete count

INTERMEDIATE STRUCTURE GROUPS

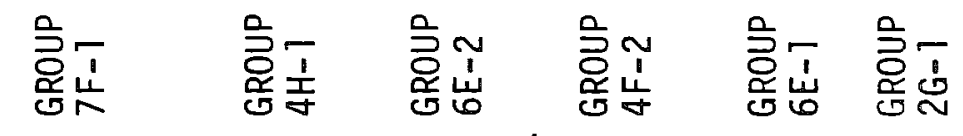
STRUCTURE GROUPS

\begin{tabular}{rrr|rrr|rrr}
- & - & - & - & - & 66.7 & - & - & - \\
100.0 & 100.0 & 97.4 & 99.7 & 100.0 & 95.5 & 99.2 & 100.0 & 97.7 \\
- & - & 2.6 & 0.2 & - & 5.0 & 0.8 & - & -1
\end{tabular}

$\begin{array}{lll}- & - & 2 .\end{array}$

$\begin{array}{lll}100.0 & 2.1 & 55.3\end{array}$

$97.3 \quad 98.2$

97.7

$\begin{array}{lll}98.6 & 100.0 \quad 99.0\end{array}$ $-$

$42.5 \quad 84.4 \quad 96.6$

$58.5 \quad 15.6$

41.9

84.

3.

100.

$99.7 \quad 100.0$

$0.3-$

59.

98.8

100.0

$99.7 \quad 100.0$

0.3 -

\begin{tabular}{ccc|ccc}
100.0 & 100.0 & 33.3 & 100.0 & 100.0 & 100.0 \\
- & - & 66.7 & - & - & - \\
99.7 & 100.0 & 95.5 & 99.2 & 100.0 & 97.7 \\
0.2 & - & 5.0 & 0.8 & - & -
\end{tabular}
$97.9 \quad 42.1$

$\begin{array}{lll}8.8 & 0.1 & 3.6\end{array}$

8.8

$\begin{array}{rr}0.1 & 3.6 \\ 4.9 & 2.3 \\ -0.1 & 5.8\end{array}$

5.2
94.8
5.2
94.8
-
100.
0.
3.2
0.2

5.2
94.8
5.2
94.8
-
00.
0.4
3.2
0.2

86.5
13.5

90.

100.

86.5

10.0

89.5

89.5
10.5

$-$

-3
5.8 100.0

$-$

4.4

4.4
4.8

1.5
-
-
10.4
10.1
12.0

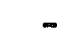

$96.6 \quad 100.0$ 3.4 $\begin{array}{ccc}100.0 & 96.6 & 100.0 \\ - & 3.4 & -\end{array}$

100.0

1.3
1.3
-

$9.6 \quad 16.9$

$9.9 \quad 16.9$ 


\begin{tabular}{|c|c|c|c|c|c|c|c|c|c|c|c|c|c|}
\hline & \multirow{2}{*}{ 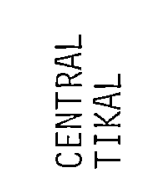 } & \multirow{2}{*}{ 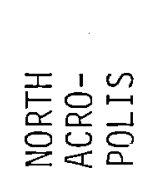 } & \multirow{2}{*}{ 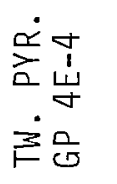 } & \multirow{2}{*}{ 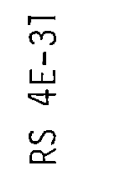 } & \multirow{2}{*}{$\begin{array}{l}\frac{20}{2} \\
\frac{1}{2} \\
2 \\
2\end{array}$} & \multirow{2}{*}{ 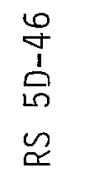 } & \multirow{2}{*}{$\begin{array}{l}5 \\
\stackrel{1}{N} \\
心 \\
ٌ\end{array}$} & \multirow{2}{*}{$\begin{array}{l}\frac{1}{1} \\
\frac{5}{\sigma} \\
\Xi \\
心\end{array}$} & \multirow{2}{*}{$\begin{array}{l}\sim \\
1 \\
w \\
0 \\
\sim \\
\sim\end{array}$} & \multirow{2}{*}{ 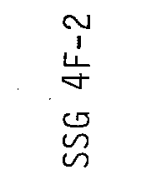 } & \multirow{2}{*}{$\begin{array}{l}T \\
\tilde{b} \\
心 \\
\tilde{n}\end{array}$} & \multirow{2}{*}{ 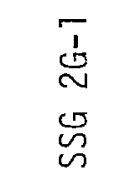 } \\
\hline & & & & & & & & & & & & & \\
\hline $\begin{aligned} \text { Gn Ex: Local fl in } \\
\text { Imptd fl in } \\
\text { Obsidian }\end{aligned}$ & $\begin{array}{l}t \% \\
\text { t } \% \\
\%\end{array}$ & $\begin{array}{r}81.0 \\
0.9 \\
18.1\end{array}$ & $\begin{array}{r}72.5 \\
0.2 \\
27.3\end{array}$ & $\begin{array}{r}85.1 \\
0.5 \\
14.4\end{array}$ & $\begin{array}{r}86.6 \\
3.2 \\
10.2\end{array}$ & $\begin{array}{r}79.6 \\
3.0 \\
17.4\end{array}$ & $\begin{array}{r}64.9 \\
4.8 \\
30.3\end{array}$ & $\begin{array}{r}71.2 \\
4.8 \\
23.9\end{array}$ & $\begin{array}{r}89.0 \\
2.0 \\
9.0\end{array}$ & $\begin{array}{r}80.8 \\
1.9 \\
17.3\end{array}$ & $\begin{array}{r}56.3 \\
0.8 \\
42.9\end{array}$ & $\begin{array}{c}90.8 \\
- \\
9.2\end{array}$ & $\begin{array}{r}93.5 \\
0.9 \\
5.6\end{array}$ \\
\hline $\begin{array}{l}\text { Flint:Gn Ex } \\
\text { Choppers } \\
\text { Elongates } \\
\text { All Bif-R/Os } \\
\text { P/C Choppers } \\
\text { Point-knives } \\
\text { Scrapers } \\
\text { Drills } \\
\text { Flake-blades } \\
\text { Flake cores } \\
\text { Unret. flakes }\end{array}$ & $\begin{array}{l}\% \\
\% \\
\% \\
\% \\
\% \\
\% \\
\% \\
\% \\
\% \\
\% \\
\%\end{array}$ & $\begin{array}{c}44,039+ \\
3.0 \\
1.4 \\
0.9 \\
0.3 \\
1.3 \\
2.3 \\
0.8 \\
1.1 \\
3.9 \\
83.8\end{array}$ & $\begin{array}{l}699 \\
4.0 \\
1.9 \\
2.3 \\
1.0 \\
0.9 \\
3.0 \\
0.7 \\
1.0 \\
13.3 \\
69.5\end{array}$ & $\begin{array}{l}155 \\
9.0 \\
0.6 \\
0.6 \\
- \\
1.9 \\
3.9 \\
0.6 \\
- \\
17.4 \\
65.8\end{array}$ & $\begin{array}{l}141 \\
5.7 \\
2.8 \\
- \\
0.7 \\
4.2 \\
0.7 \\
0.7 \\
- \\
2.1 \\
82.8\end{array}$ & $\begin{array}{l}109 \\
8.2 \\
2.7 \\
2.7 \\
- \\
3.7 \\
4.6 \\
2.7 \\
- \\
5.5 \\
68.8\end{array}$ & $\begin{array}{r}101 \\
3.0 \\
5.0 \\
1.0 \\
1.0 \\
7.0 \\
3.0 \\
1.0 \\
1.0 \\
8.0 \\
75.0\end{array}$ & $\begin{array}{r}127 \\
13.4 \\
7.1 \\
3.9 \\
1.6 \\
5.5 \\
2.4 \\
0.8 \\
2.4 \\
7.9 \\
52.7\end{array}$ & $\begin{array}{r}325 \\
11.7 \\
2.7 \\
0.9 \\
- \\
3.7 \\
1.5 \\
0.9 \\
0.9 \\
2.5 \\
74.8\end{array}$ & $\begin{array}{l}86 \\
9.3 \\
4.6 \\
- \\
1.2 \\
3.5 \\
8.7 \\
2.3 \\
1.2 \\
15.1 \\
52.3\end{array}$ & $\begin{array}{c}3,273+ \\
2.5 \\
1.0 \\
0.6 \\
0.1 \\
1.9 \\
1.1 \\
0.4 \\
0.2 \\
5.5 \\
86.1\end{array}$ & $\begin{array}{r}286 \\
3.8 \\
1.4 \\
1.4 \\
1.0 \\
0.3 \\
1.4 \\
1.0 \\
1.4 \\
0.7 \\
88.5\end{array}$ & $\begin{array}{r}727 \\
3.6 \\
0.7 \\
- \\
0.3 \\
1.0 \\
1.1 \\
0.4 \\
0.4 \\
1.1 \\
91.3\end{array}$ \\
\hline Cores:Flakes & & 21.5 & 5.2 & 3.8 & 39.0 & 12.5 & 9.4 & 6.7 & 30.4 & 3.5 & 15.6 & 126.5 & 83.0 \\
\hline $\begin{array}{l}\text { Obsidian:Gn Ex } \\
\text { Point-knives } \\
\text { Flake-blades } \\
\text { F-b cores \& fr } \\
\text { Flakes (a11) }\end{array}$ & $\begin{array}{l}\% \\
\% \\
\% \\
\% \\
\% \\
\%\end{array}$ & $\begin{array}{c}9,705+ \\
2.2 \\
79.4 \\
3.6 \\
14.2\end{array}$ & $\begin{array}{r}262 \\
3.8 \\
88.2 \\
0.8 \\
5.0\end{array}$ & $\begin{array}{r}26 \\
3.8 \\
65.4 \\
7.7 \\
23.7\end{array}$ & $\begin{array}{r}16 \\
6.2 \\
81.2 \\
12.5 \\
-\end{array}$ & $\begin{array}{r}23 \\
8.7 \\
73.9 \\
- \\
17.4\end{array}$ & $\begin{array}{r}44 \\
6.8 \\
70.4 \\
9.7 \\
11.4\end{array}$ & $\begin{array}{r}40 \\
5.0 \\
75.0 \\
7.5 \\
12.5\end{array}$ & $\begin{array}{r}32 \\
6.2 \\
75.0 \\
- \\
18.7\end{array}$ & $\begin{array}{r}18 \\
11.1 \\
83.3 \\
5.5 \\
-\end{array}$ & $\begin{array}{r}2,457 \\
0.4 \\
77.1 \\
2.0 \\
20.3\end{array}$ & $\begin{array}{r}29 \\
3.4 \\
93.1 \\
- \\
3.4\end{array}$ & $\begin{array}{r}43 \\
2.3 \\
88.4 \\
2.3 \\
4.6\end{array}$ \\
\hline $\begin{array}{c}\text { Grey obs.cores: } \\
\text { blades-Total } \\
- \text { Gn Ex } \\
-S p \text { Dp }\end{array}$ & $\begin{array}{l}\text { Take } \\
\% \\
\%\end{array}$ & $\begin{array}{l}(15.8) \\
22.1 \\
(14.2)\end{array}$ & $\begin{array}{l}(19.8) \\
111.5 \\
(14.5)\end{array}$ & $\begin{array}{r}13.2 \\
8.5 \\
18.0\end{array}$ & $\begin{array}{l}6.5 \\
6.5 \\
-\end{array}$ & $\begin{array}{l}- \\
- \\
-\end{array}$ & $\begin{array}{l}10.0 \\
10.0 \\
-\end{array}$ & $\begin{array}{r}9.8 \\
10.0 \\
9.8\end{array}$ & - & - & $\begin{array}{c}37.9 \\
37.9 \\
-\end{array}$ & - & $\begin{array}{c}38.0 \\
38.0 \\
-\end{array}$ \\
\hline $\begin{array}{r}\text { Flake-Blades-Flir } \\
\text { Obsidian-Total } \\
- \text { Gn Ex } \\
\text {-Sp Dp }\end{array}$ & $\begin{array}{l}n t: \\
\% \\
\%\end{array}$ & $\begin{array}{c}(51.2) \\
16.5 \\
(264.9)\end{array}$ & $\begin{array}{c}(239.5) \\
33.0 \\
(284.0)\end{array}$ & $\begin{array}{l}- \\
-\end{array}$ & $\begin{array}{l}- \\
- \\
-\end{array}$ & $\begin{array}{l}- \\
- \\
-\end{array}$ & $\begin{array}{l}17.3 \\
31.0 \\
10.5\end{array}$ & $\begin{array}{r}110.5 \\
10.0 \\
412.0\end{array}$ & $\begin{array}{l}7.0 \\
8.0 \\
4.0\end{array}$ & $\begin{array}{c}17.0 \\
15.0 \\
-\end{array}$ & $\begin{array}{c}315.8 \\
315.8 \\
-\end{array}$ & $\begin{array}{l}7.0 \\
6.7 \\
-\end{array}$ & $\begin{array}{c}12.7 \\
12.7 \\
-\end{array}$ \\
\hline
\end{tabular}


have been status symbols (suggested by Joseph Michels). Usually the ISGs had more bifacially worked artifacts than either RSs or SSGs. Choppers were relatively much more common in IGSs than anywhere else.

Unretouched flint flakes were the most common artifact type at all 1oci, comprising from 52.3 to $91.3 \%$ of the sample considered. However, they are consistentiy most numerous in the SSGs, thereby lowering the percentages of secondarily shaped artifacts which were also invariably present. For example, SSG 4F-2 produced 82 choppers, many of them whole. But the percentage of choppers is only $2.5 \%$ due to the presence of over 2818 unretouched fl int flakes. If unretouched flint flakes and flake cores are subtracted from the flint found in general excavations, more overlap occurs in the distributions of various types of secondarily worked artifacts. Yet point-knives are still proportionately more frequent in RSs and choppers are still more frequent in the ISGs.

Why the SSGs produced so many unretouched flint flakes is difficult to answer now. Unfortunately, at the time of excavation little attention was directed towards distinguishing usable flakes from debitage. The ratio of flake cores to unretouched flakes is too variable to be helpful here. A high ratio of cores to flakes might indicate a workshop situation. A low ratio might indicate that flakes were being used as tools in some activity. However, the possibility that cores might have been further utilized, perhaps as chopping-tools or hammerstones, and therefore not classified as cores, also comes to mind. A study underway by Lilita Bergs may shed Tight on this problem.

Most of the obsidian found at Tikal was in the form of flake-blades. The percentage of obsidian flake-blades in general excavations was somewhat higher in SSGs than in ISGs, and lowest in RSs. A lower percentage of flake-blades is usually associated with a higher percentage of flakes, suggesting a possible classification problem during the early years of excavation at Tikal. Most of the obsidian flakes studied and catalogued in later years were smal1 and irregular, and were probably debitage. In contrast to flint flakes, larger flakes of obsidian showing signs of edge use, or retouched into scrapers, were uncommon.

Distribution of obsidian flake-blade cores and fragments was spotty. The highest percentage was in RSs (but none occurred in RS 5D-15) and ISGs had more than SSGS (but none occurred in ISG $4 \mathrm{H}-1$ ).

The grey obsidian core: flake-blade ratio was equaliy random. Even SSG 4F-2 with its obsidian workshop had proportionately fewer flake-blade cores or fragments. Complete cores were also very rare; not only in the studied sample but in Tikal as a whole' (135 of 1807 cores and fragments). Apparently few exhausted cores were simply discarded. Most seem to have been reworked. Many were broken into pieces, deliberately, as indicated by the standardized forms of the fragments. Many were reworked into eccentrics. In addition, many exhausted cores and identifiable core fragments were specially deposited, and account for the somewhat higher proportion of cores and core fragments in special deposits.

The studied sample included the debris left by at least two obsidian workshops (Table 2). Localized workshop debris of Ik ceramic complex date 
(Tepeu 1) was discovered in SSG 4F-2 (1ot 20A/14) and redeposited workshop debris associated with Late Preclassic, Early Classic, and Ik complex sherds turned up in construction fill of Str. 5D-33 on the North Acropolis (lot 12L/28). Not included in this sample was a third, probably redeposited workshop of Early Classic date associated with Str. SE-454 (Op. 132F) in the Peripheral Area of Tikal (Becker 1973: 399), and a fourth, redeposited workshop associated with Late Preclassic and Early Classic sherds at the Str. 6C-60 1ocus (0p. 66D). Of these four, all but the redeposited workshop on the North Acropol is were associated with SSGs. No artifacts identifiable as stone-knapping tools, either of stone, bone, or antler, were associated with any of these workshop concentrations.

The redeposited debris of yet another obsidian workshop may be present in ISG 7F-1 (Haviland, Tikal Report No. 22). The limestone block fill of Str. 7F-30 included pockets of material which considered together look 1ike workshop debris (Coe and Broman 1958:32): many sma11, probably percussion-struck flake-blades, pressure flake-blade fragments, many flakes, several with patches of cortex, and 11 polyhedral core fragments. This material was designated Problematical Deposit 37 and had been specially deposited during the time of use of the Ik ceramic complex.

ISG $7 \mathrm{~F}-1$ came into existence during the latter part of the Early Classic Period. Haviland (Tikal Report No. 22) suggests that the obsidian workshop may have predated the founding group.

If the contents of Problematical Deposit 37 are indeed the remains of an obsidian workshop, then a possible explanation of the scarcity of such workshops in a site as large and as extensively excavated as Tikal is suggested. Perhaps many of them were redeposited in the 1 arge caches and exterior burial offerings (a change of opinion from that expressed in Moholy-Nagy 1975:518). Although none of these special deposits has been carefully studied in its entirety, most of them appear to be heterogeneous, including flakes, percussion and pressure flake-blades, and core fragments. Possibly the proportion of neatly-made polyhedral core fragments would distinguish redeposited workshop debris from a specially-produced offering. Perhaps percussion-struck flakes and flakeblades were specially produced to augment redeposited workshop debris. At any rate, this point obviously needs more study.

Flint flake-blade: obsidian flake-blade ratios for general excavations do not correlate well with locus type. However, there does seem to be a loose, inverse correlation with general excavation obsidian:flint ratios. It will be especially interesting to see if this tendency persists in a larger sample.

One of the more interesting results of this trial analysis was the poor correlation of general excavations obsidian: flint ratios with locus type. Averaged out, the ISGs had proportionately more obsidian than the RSs, which in turn had more than the SSGs. But there was considerable overlapping. SSG 4F-2 with its workshop had the highest proportion of obsidian 
of al1 1oci. Even after subtracting the workshop debris (Table 2), the ratio was $1: 3.0$, surpassed only by RS $5 \mathrm{D}-46$ with $7: 2.3$. A 7 though sociotechnic and ideotechnic usage of obsidian appears to relate directly to social status, technomic usage may not. Although Rathje (1972) mentions the abundance of obsidian in lowland Maya sites, other researchers like Sidrys (1974) and Stoltman (1975) feel its use was restricted to the elite. But it would seem that at least in Central Tikal (and perhaps only in Central Tikal?), obsidian was being widely distributed among all social groups.

With regard to total counts at individual 1oci, it is clear that special deposits, particularly structure caches and problematical deposits, greatly affected percentages and ratios. For example, loci with high total obsidian: flint ratios all had special deposits including a great deal of obsidian (except for SSG 4F-2 which had the workshop). Among the RSs, the locus counts from RS 4E-31 which had no flint- or obsidian-bearing special deposits more closely resemble those from SSGs than from the other two RSs considered here.

Flint and obsidian are rarely associated with burials in SSGs. They are often present in some ISG burials, for example in ISG $4 \mathrm{H}-1$, but not in others. This suggests local variation on traditional Tikal burial customs. Two burials in ISG 7F-1 included flint and obsidian eccentrics within the graves, the only known instances at Tikat.

The masses of $f 7$ int and obsidian flakes and flake-blades deposited as exterior offerings to North Acropol is tomb burials indicates a ranked society (Fried 1967:109). In view of the large quantity of local flint and imported obsidian involved, as well as the labor involved in chipping all that stone into useless little pieces, a true stratified society (Fried 1967:186) seems plausible.

In his study of Smaller Structure Groups, Haviland (Tikal Report No. 22) has identified a basic, invariably present, artifactual assemblage of ten types. Three of these are not included in this study (pottery figurines, group stone manos and metates) and two have been merged (used and unmodified flint flakes). All six of the other basic artifact types occurred in all of the analyzed loci (flint choppers, elongates, scrapers, flakes, and flake cores, and obsidian flake-blades). Of these six types, I feel that at least three were probably produced by specialists (choppers, elongates, and obsidian flake-blades). They show a high degree of standardization of form and competent workmanship. If they were made by specialists, then their wide distribution would indicate close socioeconomic integration in the Central part of Tikal during the Late Classic Period. As mentioned above, the large percentages of unretouched flakes associated with the SSGs is hard to interpret without more detailed technical data. However, together with the circumstance that three of the four known obsidian workshops were associated with SSGs, the high percentage of flint flakes suggests that the hypothetical flint-knapping specialists may also have lived and worked in the SSGS. 
A71 grey obsidian

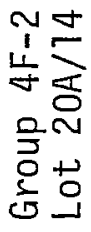

Flake-blades

Flakes

Cores \& fragments

TOTAL

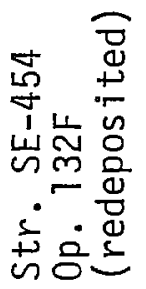

135

$12+$

7

154

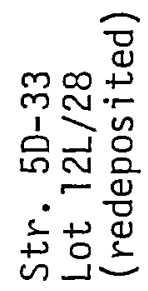

327

122

20

469

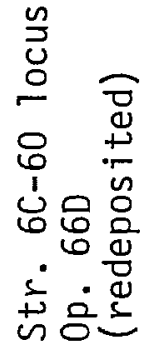

40

11

6

57 nิ

$+\square$

n.

的

बิ 음

정

엉ㅇㅇ

$T+0$

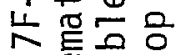

등르을

응등 ㄴํㅇ 辛

노응

371

219

11

601 
A redistributive type of economy (Sahlins 1974:189) is usually assumed for the Classic lowland Maya (cf. Culbert 1973). If this was the case in Central Tikal, then even the inhabitants of the SSGs had good connections with the redistributive node, whoever that was. Through the node they could have distributed the products of their flint and obsidian workshops to the RSGs and the ISGs. From the node they could have received imported raw obsidian and fine flint, as well as finished products of these materials.

Furthermore, the high proportion of obsidian:flint for Central Tikal as a whole (ca. 1:1.5) indicates Tikal itself was an important redistributive node in a lowland Maya obsidian network, confirming suggestions by Adams (1973:154) and others. The proportion of obsidian to flint at any given lowland Maya site appears more influenced by the size and kind of site than by the site's distance from the obsidian source (see also Johnson 1976). That lowland Maya settlement pattern was hierarchic is clear (Bullard 1960), even though the causes for this arrangement may be in dispute (Marcus 1973; Hammond 1974). A direct correlation between proportion of obsidian and size and type of site is in contrast to the situation in presumably more egalitarian societies, such as the Neolithic Near East (Dixon, Cann, and Renfrew 1968) and perhaps Formative Highland Mesoamerica (Pires-Ferreira 1975:20-24), where distance from source seems to be more significant.

In view of the variability in quantity and proportion of obsidian in lowland Maya sites, and even differences at different times during the occupation of the same site, it would seem that Rathje's (1972) characterization of obsidian as a basic resource ought to be modified. Rather than a basic resource, it was probably regarded and sought as a preferred choice for cutting tools and ceremonial deposits.

\section{CONCLUSIONS}

A few correlations between locus type and the occurrence of flint and obsidian artifacts were brought out by this trial analysis:

The three RSs were characterized by the highest percentages of pointknives, and, accordingly, of imported flint. The percentages of other secondarily worked flint and obsidian artifacts in general excavations generally trailed slightly behind those of the ISGs. RSs tended to have larger flint- and obsidian-bearing special deposits than ISGs and SSGs, and this is reflected in the total counts for the locus. For example, the counts from RS 4E-31, without such special deposits, differed somewhat from the other two RSs.

The three ISGs had the highest percentages of secondarily worked artifacts, except point-knives. ISG $4 \mathrm{H}-1$ had rather low percentages of imported flint and obsidian, which may be related to its peripheral position.

Unretouched flint flakes and obsidian flake-blades were numerous at al1 10ci. However, they comprised the highest percentages of flint and obsidian recovered from general excavations in SSGs. It is probable that specialized obsidian workers lived in SSGs; perhaps specialized flint 
workers did, too. In addition--or alternatively, given our present state of knowledge--certain processing or manufacturing activities involving the use of flint flakes may have been carried out in SSGs. Caches do not occur with SSGs at Tikal and the amount of flint and obsidian deposited with burials and problematical deposits is comparatively sma 11.

The Temple Group and Twin-Pyramid Group did now show any distinctive correlations. They are included in Table 1 for comparative purposes.

The distribution of obsidian within the studied sample indicated a close economic integration of Central Tikal during the Late Classic Period. This integration was reflected not only by the presence of obsidian at each locus, but also by the remains of at least two workshops indicating obsidian-working specialists. The presence of flint-working specialists is suggested but not established.

It cannot be said that the results of this trial analysis produced new information on ancient activities associated with each locus. Nevertheless, it produced a few correlations which may prove to be characteristic of certain structure and group types once a larger sample is analyzed.

Future research is planned which will also take into account all portable artifacts and ecofacts, not just flint and obsidian. If an overview of all of the surviving materials from a given locus could be achieved--if we could lay out all the remaining puzzle pieces on the same table--the chances of deducing the activities that once took place at that locus would be greatly improved.

\section{ACKNOWLEDGEMENTS}

I thank W. A. Haviland for his comments on an earlier version of this paper.

The assistance of Professor L. G. Löffler of the Ethnological Seminar, University of Zurich, and the Stiftung für Wissenschaftliche Forschung, in enabling me to attend the Maya Lithic Technology Conference is gratefully acknowledged.

\section{REFERENCES CITED}

Adams, R. E. W.

1973 Maya Collapse: Transformation and Termination in the Ceramic Sequence at Altar de Sacrificios. In: The Classic Maya Collapse (edited by T. P. CuTbert):133-163. University of New Mexico Press, Albuquerque.

Becker, M. J.

1971 The Identification of a Second Plaza Plan at Tikal, Guatemala. Ph.D. dissertation, University of Pennsylvania. University Microfilms, Ann Arbor. 
1973 Archaeological Evidence for Occupational Specialization Among the Classic Period Maya at Tikal, Guatemala. American Antiquity 38(4):396-406.

Bullard, W. R.

1960 Maya Settlement Pattern in Northeastern Peten, Guatemala. American Antiquity 25(3):355-372.

Carr, Ro, and J. Hazard

1961 Map of the Ruins of Tikal, El Peten, Guatemala. Tikal Report 11. University Museum, Philadelphia.

Coe, W. R.

1957 A Distinctive Artifact Common to Haiti and Central America. American Antiquity 22:280-282.

1967 Tikal: A Handbook of the Ancient Maya Ruins. The University Museum, Philadelphia.

Coe, W. R. and V. L. Broman

1958 Excavations in the Stela 23 Group. Tikal Report 2. University Museum, Philadelphia.

Culbert, T. P., editor

1973 The Classic Maya Collapse. University of New Mexico Press, Albuquerque.

Dixon, J. E., J. R. Cann, and C. Renfrew

1968 Obsidian and the Origins of Trade. Scientific American $218(3): 38-46$.

Fried, M. H.

1967 The Evolution of Political Society. Random House, New York. Hammond, N.

1974 The Distribution of Late Classic Maya Major Ceremonial Centres in the Central Area. In: Mesoamerican Archaeology: New Approaches (edited by N. Hammond):313-334. University of Texas Press, Austin.

Harrison, P. D.

1970 The Central Acropolis, Tikal, Guatemala. Ph.D. dissertation, University of Pennsylvania. University Microfilms, Ann Arbor. 
Haviland, W. A.

1963 Excavations of Sma11 Structures in the Northeast Quadrant of Tikal, Guatemala. Ph.D. dissertation, University Microfilms, Ann Arbor.

1974 Occupational Specialization at Tikal, Guatemala: Stoneworking-Monument Carving. American Antiquity 39(3):494-496.

n.d. Tikal Reports $20,21,22$. Manuscripts.

Hi11, J. N.

1968 Broken K Pueb7o: Patterns of Form and Function. In: New Perspectives in Archaeology (ed. by S. R. Binford and L. R. Binford):103-142. Aldine Publishing Company, Chicago.

Johnson, J. K.

1976 Site Hierarchy in the Western Maya Periphery. Paper read at the 41st Annual Meeting of the Society for American Archaeology, St. Louis.

Jones, C.

1969 The Twin-Pyramid Group Pattern. Ph.D. dissertation, University of Pennsylvania. University Microfilms, Ann Arbor.

Kidder, A. V.

1947 The Artifacts of Uaxactun, Guatemala. Carnegie Institution of Washington, Publication 576.

Longacre, W. A.

1968 Some Aspects of Prehistoric Society in East-Central Arizona. In: New Perspectives in Archaeology (ed. by S. R. Binford and L. R. Binford):89-102. Aldine Publishing Company, Chicago.

Marcus, J.

1973 Territorial Organization of the Lowland Classic Maya. Science 180(4089):911-916.

Moholy-Nagy, $\mathrm{H}$.

1975 Obsidian at Tikal, Guatemala. Actas del XLI Congreso Internacional de Americanistas, I:511-518. Mexico.

Pires-Ferreira, J. W.

1975 Formative Mesoamerican Exchange Networks with Special Reference to the Valley of Oaxaca. Memoirs of the Museum of Anthropology, University of Michigan 7. 
Rathje, W. L.

1972 Praise the Gods and Pass the Metates. In: Contemporary Archaeology (ed. by M. P. Leone):365-392. Southern I11 ino is Press, Carbondale.

Sahtins, M.

1974 Stone Age Economics. Tavistock Publications, London. Sheets, P. D.

1975 New World Lithic Analys is Symposium: Southern Mesoamerica. Paper read at the 40th Annual Meeting of the Society for American Archaeology, Dallas.

Sidrys, R. V.

1974 Classic Maya Obsidian Trade. Revised version of a paper read at the 38th Annual Meeting of the Society for American Archaeology, San Francisco.

Spence, M. W.

1974 Residential Practices and the Distribution of Skeletal Traits in Teotihuacan, Mexico. Man 9(2):262-273.

Spence, M. W. and P. G. Wiegand

1968 Some Patterns of Obsidian Exploitation and Trade in Northern Mesoamerica. Paper read at the 33rd Annual Meeting of the Society for American Archaeology, Santa Fe.

Stol tman, J. B.

1975 An Analysis of Chipped Stone Artifacts from Becan, Campeche, Mexico. Revised version of a paper read at the 73rd Annual Meeting of the American Anthropological Association, Mexico.

Tolstoy, P.

1971 Utilitarian Artifacts of Central Mexico. In: Handbook of Middle American Indians 10, Pt. 1:270-296. University of Texas Press, Austin.

Wilk, R.

1976 Superficial Examination of Structure 100, Colha. In: Archaeology in Northern Belize: British Museum-Cambridge University Corozal Project 1974-75 Interim Report:152-173. 
Willey, G. R., W. R. Bullard, J. B. Glass, and J. C. Gifford

1965 Prehistoric Maya Settlements in the Belize Valley. Papers of the Peabody Museum of Archaeology and Ethnology. Harvard university 54. 
SOME SOCIOLOGICAL OBSERVATIONS ON OBSIDIAN PRODUCTION

AT KAMINALJUYU, GUATEMALA

Joseph W. Michels

INTRODUCTION

Ninety-five percent of all obsidian found at Kaminaljuyu comes from the E1 Chayal Magma located approximately $20 \mathrm{~km}$ to the northeast (Hurtado de Mendoza 1973:48). On-site inspection at one of the principal chipping stations (the EI Chayal site) indicates that quarry-centered operations involved the production of blade cores (Miche1s 1975:103). Prodigious quantities of large blades and large flakes were produced as by-products, and were used in situ for the operation of heavy-duty woodworking industry (ibid.). The finished blade cores were transported elsewhere for blade production.

From the beginning of the Late Formative (500 B.C.) to the end of the late Late Classic (A.D. 1000) Kaminaljuyu was a principal center of both blade production and blade consumption. This is understandable since the El Chayal magma is located in territory controlled by Kaminaljuyu, and all quarried extrusion points of the magma would be subject to Kaminaljuyu administration.

Yet Kaminaljuyu appears to be only one of three major political entities that share common frontiers within the Valley of Guatemala. The southern end of the valley and the uplands to the southeast comprise an autonomous political unit called the Amatitlan chiefdom (Brown 1975). The upper portion of the western slopes of the valley and adjacent SacatepequezChimaltenango uplands comprise a second autonomous political unit, which I call the Chimaltenango chiefdom. The Kaminaljuyu chiefdom, itself, consists of the northern half of the valley and the topographically rugged drainage system to the northeast. Studies conducted by both Brown (1975) and myself (Michels n.d.) would seem to indicate that these three contiguous chiefdoms coexisted, autonomously, ever since their emergence in the Late Formative.

There are several economically strategic features located within Kaminaljuyu territory. The territory includes the major access routes connecting the Valley of Guatemala with the Matagua Valley--a principal artery of Mesoamerican inter-regional commerce. In addition, as mentioned earlier, the El Chayal obsidian region is located within the territory. Final1y, the famous Chinautla clays are mined here; clays which were used in the production of fine ceramic vessels from very early in the occupational history of Kaminaljuyu right up to the present day (Rice 1976).

\section{THE SOCIAL ORGANIZATION OF KAMINALJUYU}

Kaminaljuyu is a conical clan chiefdom that consists of five sub-chiefdoms that collectively occupy an area of approximately 150 square $\mathrm{km}$, forming the immediate sustaining area of the site of Kaminaljuyu. In addition, Kaminaljuyu administers extensive dependent territories north and northeast of the immediate sustaining area. Provisional demographic reconstruction 
suggests that the immediate sustaining area and the site of Kaminaljuyu, combined, had a Formative Period population that grew from 4,000 to 10,000 persons, and a Classic Period population that reached a height of about 22,000 persons.

The site of Kaminaljuyu, itself, occupies 7.5 square $\mathrm{km}$, and is divided into five local lineage precincts of roughly equal area. Each precinct accommodates the residential and ceremonial needs of the paramount lineage of one of the five sub-chiefdoms. Each sub-chiefdom, and the Kaminaljuyu precinct with which it is connected, is named after a principal modern town located within its area. Starting from the north and moving in a clockwise manner they are the El Incienso, the Santa Rosita, the Caterina Pinula, the San Carlos, and the Mixco sub-chiefdoms. The paramount lineages of the five sub-chiefdoms are ranked, and although during specific phases there are exceptions, generally speaking they have a long-term rank order that conforms with the sequence in which I named them above. That is, the El Incienso lineage ranks highest and the Mixco lineage ranks lowest. The El Incienso lineage chief is therefore the paramount political and religious leader of the Kaminaljuyu chiefdom. The Acropolis and Palangana which form the well-known Acropolis Complex (Cheek 1976), with its Teotihuacan-style architecture, represents the ceremonial and residential center of the ET Incienso lineage during the Middle Classic and early Late Classic phases.

By the Middle Classic phase an intermediate subdivision emerges that causes the five sub-chiefdoms to be grouped into two organizational entities, which I have called districts. The El Incienso and Santa Rosita sub-chiefdoms (ranked I and II respectively) form the Northeast district. And the Caterina Pinula, San Carlos and Mixco lineages (ranked III, IV, and V respectively) form the Southwest district. As might be expected from the internal ranking of the grouped 1 ineages, the two districts are themselves ranked; with the Northeast district of higher rank than the Southwest district. District ranking can be explained by the fact that al 1 economically strategic resources of the chiefdom are located in dependent territories administered by the Northeast district. The El Incienso subchiefdom appears to control the northern access routes as well as the Chinautla pottery-making communities. The Santa Rosita sub-chiefdom, on the other hand, seems to control the obsidian producing hamlets of the El Chayal region. In fact, the Southwest district sub-chiefdoms are effectively deprived of extensive dependent territories since their lands abut almost directly upon the frontiers of the Amatitlan and Chimaltenango chiefdoms.

Each of the five paramount, but ranked, lineages that reside at Kaminaljuyu and that form the ruling elite of the Kaminaljuyu chiefdom is characterized by dual organization. The dual organization does not achieve institutional expression until the beginning of the Late Terminal Formative phase, but once manifested it maintains an institutional presence until the end of the early Late Classic phase. I have named the organizational entities resulting from dual organization moieties. Architectural manifestation of moiety units demonstrates that each 1 ineage precinct can be divided into moiety sectors. These sectors appear to be more or less stable over a five 
phase trajectory (1000 years). That moiety sector of each 1 ineage precinct in which the sub-chiefdom's elaborate Early Terminal Formative ceremonial complex was located is designated Moiety A. The remaining sector is designated Moiety B. Moiety A and B sectors of each Tineage precinct possess roughly comparable architectural complexes. Despite this, however, the moieties are of unequal rank. Mojety A tends to rank higher than Moiety $B$ for all lineages and for a 11 seven phases for which comparisons could be made.

Cutting across the organizational structure summarized above is a class hierarchy that divides the population of Kaminaljuyu into four basic strata. Rank I households constitute a paramount elite. Rank II households represent a secondary elite. Rank III households, on the other hand, are moderately affluent commoners. And Rank IV households constitute the low status retainer or peasant stratum of society.

The evidence supporting the sociopolitical reconstruction of Kaminaljuyu given in this paper will be published in detail by me in a book currently being prepared for publication (Michels n.d.). My summary here is intended to serve as a sociological framework within which I can make a series of observations regarding obsidian production at Kaminaljuyu.

\section{OBSIDIAN PRODUCTION}

Using the distribution of exhausted polyhedral cores as a principal indicator, I can report that almost one-quarter $(23 \%)$ of the 512 households studied at Kaminaljuyu within a seven phase (1500 year) time frame were involved in obsidian blade production. How that percentage was distributed with respect to district, lineage, moiety, and social class subdivisions, and how that distribution changes over time, is the subject of this part of the paper.

The Late Formative Phase (500 B.C.-200 B.C.)

Overal1, $21 \%$ of the 28 Late Formative households sampled were involved in blade production. By sub-chiefdom precinct, the percentage of households involved in blade production is:

$\begin{array}{ll}\text { El Incienso }-20 \% & \text { San Carlos }-75 \% \\ \text { Santa Rosita }-7 \% & \text { Mixco }-0 \% \\ \text { Caterina Pinula }-25 \% & \end{array}$

Two of these figures are especialiy noteworthy. The fact that Santa Rosita had only $7 \%$ of its households involved, yet is believed to be in political control of the El Chayal obsidian hamlets, would suggest that a deliberate policy of redistribution not only deprives it of a monopoly on blade production comparable to its purported monopoly on core production but mitigates against its participation in this aspect of the industry on an equitable basis. The fact that San Carlos, on the other hand, had $75 \%$ of its households involved suggests, furthermore, that the latter was a privileged recipient of the output of El Chayal blade cores. San Carlos may, on the basis of the lopsided percentage figures, be thought of as having an industrial focus on the manufacture of prismatic blades. 
During the Late Formative dual organization had not yet been institutionalized, and moiety sectors must be extrapolated backward in time on the basis of patterning in subsequent phases. On that basis, however, all blade production can be associated with households located in Moiety $A$ sectors of the sub-chiefdom precincts.

On examination of the distribution of blade production along social class lines, one finds that $33 \%$ of blade producing households belong. to the paramount elite, while $67 \%$ belongs to the class of low ranked commoners. This disparity in favor of non-elite households is unique among the seven phases for which adequate data is available. What is interesting is that the disparity is associated with district divisions. That is, all obsidian producing households in the Northeast district belong to the paramount elite, while all of the obsidian producing households in the Southwest district belong among low ranked commoners.

The Early Terminal Formative Phase (200 B.C.-A.D. 0)

For this phase $39 \%$ of the 44 households sampled were involved in blade production. By sub-chiefdom precinct, the percentage of households involved in blade production is:

$\begin{array}{ll}\text { El Incienso }-31 \% & \text { San Carlos }-50 \% \\ \text { Santa Rosita }-50 \% & \text { Mixco }-37 \% \\ \text { Caterina Pinula }-20 \% & \end{array}$

Again, we may usefully single out the Santa Rosita and San Carlos precincts. Both exhibit very high percentages, suggesting that one out of every two households in the precincts are involved in blade production. The industrial focus identified for the San Carlos precinct during the Late Formative appears to continue. However, the redistribution policy that seemed to adversely affect the Santa Rosita lineage during the Late Formative appears to no longer be in effect, since the precinct exhibits an industrial focus on blade production fully comparable to that of San Carlos.

During the Early Terminal Formative dual organization still had not yet been institutionalized, and moiety sectors must be extrapolated. On that basis, however, blade production can now be observed in both Moiety $A$ and Moiety $B$ sectors. Although there is a tendency for blade production to continue to be more heavily represented in Moiety A sectors of the site, its representation in Moiety $B$ sectors is substantial and may previsage the architectural manifestation of dual organization that occurs during the next phase.

On examination of the distribution of blade production along social class lines, one finds that $76 \%$ of blade producing households belong to the paramount elite, $18 \%$ to the secondary elite, and $6 \%$ to the class of 10 w ranked commoners. This is in sharp contrast with the distribution reported for the Late Formative. Now, a full $94 \%$ of the blade producing households are elite, while only $6 \%$ are commoners. No significant variation can be discerned along district 1 ines.

It should be noted that a secondary elite type household emerges for the 
first time at Kaminaljuyu during this phase. What is interesting is that although it is only modestly associated with blade production it is universally associated with some type of craft specialization.

The Late Terminal Formative Phase (A.D. O-A.D. 200)

Overa11, 23\% of the 65 Late Terminal Formative households sampled were involved in blade production. By sub-chiefdom precinct, the percentage of households involved in blade production is:

$\begin{array}{ll}\text { E1 Incienso }-29 \% & \text { San Carlos }-33 \% \\ \text { Santa Rosita }-0 \% & \text { Mixco }-28 \% \\ \text { Caterina Pinula }-0 \% & \end{array}$

Once again, a stringent policy of redistribution appears to adversely affect the Santa Rosita Tineage's ability to maintain an industrial focus upon blade production. And although the figures 1 isted above suggest a rough parity in blade production among three sub-chiefdom precincts, in fact the San Carlos lineage continues to dominate; as evidenced by the prodigious quantities of workshop debris concentrated in an area which can usefully be referred to as a factory site (46-32-239). The sharp drop in the number of Kaminaljuyu households involved in blade production (from $39 \%$ in the Early Terminal Formative to $23 \%$ here) might be explained by the appearance of factory-level concentrations of obsidian production in specific barrios.

Another concomitant factor is the institutionalized expression of dual organization, in the form of separate but equal ceremonial complexes within each 7 ineage precinct, that first manifests itself during this phase. However, moiety divisions do not significantly affect the distribution of blade producing households at Kaminaljuyu during this phase. In those precincts which have such households, they are almost equaliy apportioned along moiety lines.

On examination of the distribution of blade production by social class, one finds that $80 \%$ of blade producing households are elite, while only $20 \%$ are non-elite. Among elite households blade production is evenly distributed between paramount and secondary elite.

A new class category makes its first appearance at Kaminaljuyu during this phase--the Rank III commoner. It is only modestly involved in blade production; accounting for no more than $7 \%$ while the low ranked commoner accounts for $13 \%$ of such households.

When district divisions are superimposed upon class divisions one notes that there is considerably more variability in class among blade producing households of the Southwest district than among those of the Northeast district. While only the two elite classes are represented among such households in the Northeast district, all four classes are represented in the Southwest district. Furthermore, the contrast in distribution appears to be significant. Obsidian producing households in the Southwest district 
are distributed as follows: paramount elite, $30 \%$; secondary elite, $40 \%$; Rank II I commoner, 10\%; 10w ranked commoner, 20\%. While in the Northeast district the distribution is: paramount elite, $60 \%$; secondary elite, $40 \%$. It certainly seems as if, at least in the Southwest district, the locus of blade production is being cautiously divorced from its invariant association with elite residential compounds; enabling it to begin to take on the form of a cottage industry.

The Early Classic Phase (A.D. 200-A.D. 400)

Of the 104 Early Classic households sampled, $28 \%$ were involved in blade production. By sub-chiefdom precinct, the percentage of households involved in blade production is:

$\begin{array}{ll}\text { El Incienso }-25 \% & \text { San Car7os }-46 \% \\ \text { Santa Rosita }-20 \% & \text { Mixco }-18 \% \\ \text { Caterina Pinula }-27 \% & \end{array}$

The figures reveal that four of the precincts have percentages that approximate the average for Kaminaljuyu (23\%), and may therefore denote a policy of equitable distribution of El Chayal blade cores among the lineage chiefs. However, San Carlos stands out conspicuously; having almost one out of every two households involved in blade production. Once again, it seems as if San Carlos is continuing a tradition of possessing an industrial focus with respect to the obsidian working craft. Not only is there a high percentage of households involved, but also the factory-like concentrations of workshop debris continue on from the Late Terminal Formative.

An inspection of blade producing households broken down by moiety tends to reinforce the impression that the San Carlos precinct possesses a barrio of obsidian workers. For all other precincts there is no noteworthy difference in the distribution of blade producing households by moiety sector. Yet, in San Carlos $66 \%$ of all households in the Moiety B sector are engaged in blade production, compared with only $29 \%$ in the Moiety A sector. The Moiety B sector is also the locus of the factory-level concentrations of obsidian workshop debris. We may therefore conclude that Moiety $B$ of the San Carlos precinct constitutes a barrio of obsidian workers during the Early Classic phase.

On examination of the distribution of blade production along social class lines, one finds that $69 \%$ of blade producing households are elite $(66 \%$ and $3 \%$ paramount and secondary elite respectively), and $37 \%$ are non-elite ( $14 \%$ and $17 \%$ Rank III and low ranked commoners respectively). This seems to suggest that the process of divorcing the locus of blade production from its association with elite residences, glimpsed in the Late Terminal Formative, has not advanced significantly; stabilizing at a $2: 1$ ratio of elite to non-elite. This impression is reinforced when one examines the breakdown by district. No detectable difference in the household rank composition of blade producers exists between the Southwest and Northeast districts. 
The Middle Classic Phase (A.D. 400-A.D. 600)

Overal1, 23\% of the 66 Middle Classic households sampled were involved in blade production. By sub-chiefdom precinct, the percentage of households involved in blade production is
E1 Incienso - $15 \%$
Santa Rosita - $55 \%$
Caterina Pinula - 25\%
San Carlos - $27 \%$
Mixco $-8 \%$

For the first time the Santa Rosita sub-chiefdom, which is believed to control the EI Chayal obsidian quarries, has achieved a partial monopoly on the obsidian industry--dominating both its mining and its manufacture. The San Carlos lineage, which has consistently. possessed a manufacturing focus in all previous phases, now exhibits only an average complement of blade producing households. The obsidian workers' barrio of San Carlos Moiety $B$ has disappeared, and along with it the Moiety B ceremonial complex.

A new obsidian workers' barrio emerges in the Santa Rosita precinct. For a11 other precincts, including San Carlos, there is no noteworthy difference in the distribution of blade producing households by moiety sector. But in Santa Rosita. $71 \%$ of a 11 households in the Moiety A sector are engaged in blade production, compared with onty $25 \%$ in the Moiety B sector.

On examination of the distribution of blade production along social class lines, one finds that $87 \%$ of blade producing households are elite (40\% and $47 \%$ paramount and secondary elite respectively), and only $13 \%$ are those of low ranked commoners. The very modest tendency towards transforming blade production into a cottage industry, first glimpsed in the Late Terminal Formative, is effectively reversed--the association of obsidian working with elite residence is almost as pervasive as it was in the Early Terminal Formative. This holds true when broken down by district. Household rank composition of blade producers in the Northeast and Southwest districts is virtually identical ( $89 \%$ and $84 \%$ elite respectively).

The Ear7y Late Classic Phase (A.D. 600-A.D. 800)

Of the 113 Early Late Classic households sampled 18\% were involved in blade production. By sub-chiefdom precinct, the percentage of households involved in blade production is:

$\begin{array}{ll}\text { El Incienso }-4 \% & \text { San Carlos }-38 \% \\ \text { Santa Rosita }-21 \% & \text { Mixco }-15 \% \\ \text { Caterina Pinula }-12 \% & \end{array}$

The preeminence of the Santa Rosita lineage with respect to blade production was short-lived, since we observe that San Carlos resumes its traditional importance during this phase. This time, however, no single moiety sector stands out as an obsidian workers' barrio. No variation in the percentage of blade producing households per moiety sector for any of the lineage precincts, including San Carlos, appears to be significant.

On examination of the distribution of blade production along social class 
lines, one finds that $80 \%$ of blade producing households are elite $(65 \%$ and $15 \%$ paramount and secondary elite respective1y), while only $20 \%$ were non-elite (Rank IV commoners). As in the case of the Middle Classic, household rank composition of blade producers in the Northeast and Southwest districts is virtually identical.

The Late Late CTassic Phase (A.D. 800-A.D. 1000)

For this phase, $20 \%$ of the 69 households sampled were involved in blade production. By sub-chiefdom precinct, the percentage of households involved in blade production is:

$$
\begin{aligned}
& \text { El Incienso - } 30 \% \\
& \text { Santa Rosita }-11 \% \\
& \text { Caterina Pinula }-15 \%
\end{aligned}
$$

San CarTos - $13 \%$

Mixco $-27 \%$

All precincts exhibit average or below average obsidian working activity, suggesting that no single lineage precinct had a special industrial focus upon blade production. The El Chayal blade cores underwent a more or less equitable redistribution among the five 1 ineage chiefs. This fact may suggest that the industrial focus of blade production may have shifted away from the site of Kaminaljuyu to some other center. The most promising candidate would be the site of Azacualpi11a (24-22-010), located right in the heart of the El Chayal region. Ba11 court alignment (Brown 1973:440) and obsidian dates indicate that Azacualpilla was initially built during the Middle Classic. Yet obsidian dates also make it clear that fully half of the occupational time frame for the site falls within the late Late Classic and the early part of the early Post Classic (A.D. 800-A.D. 1100) (see Table 1). One implication of this would be that the power of the Kaminaljuyu chiefdom was on the decline, enabling dependent territories, such as that which Azacualpilla controlled, to assert their independence. B.Tade production for purposes of long distance trade may therefore have effectively bypassed Kaminaljuyu beginning in this phase.

A concomitant feature was the disappearance of virtually all monumental architecture from Kaminaljuyu, and the simultaneous construction of "moietyscale" civic centers within the northern, northwestern and northeastern peripheral segments of the Kaminaljuyu's immediate sustaining area.

Perhaps most striking of a 1 , is the observation that the distribution of blade production along class lines is altered significantly. For the first time since the Late Formative there is a breakdown in the tenacious association of blade production with elite status. Just as many blade producing households are now non-elite as are elite $(50 \%$ and $50 \%$ respectively). This is an important symptom of the dislocations that marked the Kaminaljuyu chiefdom during this phase. By the end of the late Late Classic Kaminaljuyu, as a political, economic and religious center, ceases to exist. A17 that remains in the Early Post Classic is a population slightly larger than that of the Middle Formative, consisting of Rank II and Rank IV households. 


\section{CONCLUSIONS}

The sociology of blade production at Kaminaljuyu reveals that all structural components of Kaminaljuyu society, at one time or another, impinge upon the industry. District, lineage, moiety, and social class divisions have all proved to be determinants of the distribution of this industry among the inhabitants of the site. Similarly, the transformational sequence represented by the seven phase time frame within which the study was undertaken demonstrates that blade production as an industry is affected by overal1 systemic change affecting the Kaminaljuyu chiefdom.

Much of the sociology of blade production, and its change through time, should become understandable in the context of how the full economic subsystem operates. This is especially true concerning the policy underlying blade core redistribution. Towards this end, some progress has been made in the analys is of "exotica" craft industries, that supply the needs of the Rank I households as well as much of the sumptuous mortuary furnishings to be found in Kaminaljuyu tombs. Preliminary findings would suggest that such industries were often responsible for heavy consumption of prismatic blades. This may imply that blade production within the site of Kaminaljuyu was intended almost exclusively for local consumption. And that, especially from Middle Classic times on, factory sites which produced blades for export remain to be found outside Kaminaljuyu, in the northeastern dependent territories.

A chipping station that can serve as a model for this type of satellite factory site is located within the village of Las Animas, Jutiapa. The site is within quick walking distance of the slopes of obsidian rich Cerro Ixtepeque. I conducted a survey of the site in 1971 and discovered prodigious quantities of exhausted polyhedral cores and very fine prismatic blade detritus. Not a single large flake or large blade, nor a single unused blade core was to be found. Las Animas is in close proximity to the site of Papalhuapa, with its monumental architecture. Las Animas is probably only one of a number of blade producing hamlets that are administered by Papalhuapa in connection with long distance trade of obsidian blades into the Peten.

The Papalhuapa-Las Animas model may apply to the El Chayal region during the Classic Period. Quarry-centered sites, such as El Chayal (25-00-249) extract the obsidian and manufacture blade cores. Blade cores intended to supply the needs of long distance trade are routed to blade producing hamlets located in the vicinity of Azacualpilla (24-22-010). The finished prismatic blades are then brought to Azacualpilla for eventual shipment. At the same time Azacualpilla directs a portion of blade cores to Kaminaljuyu as tribute. The Santa Rosita sub-chiefdom is the direct recipient, and it, in turn, redistributes the blade cores by some formula among the lineage chiefs. They, in turn, distribute them among elite households where they finally undergo reduction. An in-depth study of this hypothes is is currently being undertaken by Luis Hurtado de Mendoza as part of his doctoral research. 
Brown, Kenneth L.

1973 The B-III-5 Mound Group: Early and Middle Classic Civic Architecture. In: The Pennsylvania State University Kamina1juyu Project - 1969, 1970 Seasons; Part One Mound Excavations (edited by Joseph W. Michels and William T. Sanders). The Pennsylvania State University, occasional Papers in Anthropology 9:391-464.

1975 The Valley of Guatemala: A Highland Port of Trade. Doctoral Dissertation, The Pennsylvania State University, University Park.

Cheek, Charles D.

1976 Excavations at the Palangana and the Acropolis, Kaminaljuyu. In: Teotihuacan and Kaminaljuyu: A Study in Prehistoric Culture Contact (edited by WiTliam T. Sanders and Joseph W. Miche1s). The Pennsylvania State University Press, University Park (in press).

Hurtado de Mendoza, Luis

1973. Neutron Activation Analys is of Kaminaljuyu Obsidian. In: The Pennsylvania State University KaminaTjuyu Project 1969, 1970 Seasons; Part One - Mound Excavations (edited by Joseph W. Michels and William T. Sanders). The Pennsylvania State University, occasional Papers in Anthropology 9:43-54.

Miche1s, Joseph $W$.

1973 Radiocarbon and Obsidian Dating: A Chronometric Framework for Kaminaljuyu. In: The Pennsylvania State University Kamina1juyu Project - 1969, 1970 Seasons; Part One Mound Excavations (edited by Joseph W. Michels and William T. Sanders). The Pennsylvania State University, Occasional Papers in Anthropology 9:21-66.

1975 El Chayal, Guatemala: A Chronological and Behavioral Reassessment. American Antiquity 40:103-106.

n.d. Kaminaljuyu: The Social Organization of a Precolumbian Chiefdom. Cummings Press, Palo A7to (in preparation).

Rice, Prudence E.

1976 Ceramic Continuity and Change: A Technological Study of The White Wares from the Bas in of Guatemala. Doctoral Dissertation, The Pennsylvania State University, University Park. 


\title{
ARTI-FACT OR FICTION?: THE LITHIC OBJECTS \\ FROM RICHMOND HILL, BELIZE
}

\author{
Arlene V. Miller
}

\section{INTRODUCTION}

The site of Richmond Hill is located in a bajo or seasonal swamp in the Orange Walk District of northern Belize. In an area dominated archaeologically by Classic Maya debris, not a single Maya-1ike implement was recorded at Richmond Hill, nor were there any evidences of ceramic sherds., The Tithic objects recovered were thick in cross section, often with oblique edge angles. The problem remains as to whether these lithic materials are artifacts or naturally formed geofacts. Assuming that Richmond Hill is in fact an archaeological site, one must then determine whether it represents a pre-ceramic occupation or if the artifacts constitute a phase of Classic Maya lithic technology previously unrecognized by archaeologists.

The goal of this paper is to answer the following question: can the 1ithic objects from the site of Richmond Hill, Belize be classified as artifacts of human manufacture and use, or were natural agents responsible for the flaking, striations and other observed modifications characterizing this collection? It is well known that certain lithic objects, undergoing natural geologic processes, can exhibit morphological features which closely resemble artifacts of human manufacture. The problem of determining whether a given stone object is truly an artifact or naturally formed has been discussed by many authors (e.g., Barnes 1939, Carter 1967, Harner 1956, Rose 1968) and severa 1 criteria have been utilized that aid in separating true artifacts from geofacts. These inciude (1) investigation of the cultura 7 and/or geological context from which the stones were derived (C1ark 1958:76; Heider 1960); (2) examination of related collections with a known cultural context for implements of similar morphology and lithic material (Rose 1968:240); (3) investigation of the mechanics involved in producing the type of fractures which created the morphology of the stones (Rose 1968:243; Clark 1958:76), and (4) determining if certain regularities in the patterns of flaking are the same as those which would be expected from flaking patterns found on artifacts (Carter 1967:4).

In the specific case of the 1 ithic objects from Richmond $H i 11$, evidence can be presented which supports both sides of this problem. The aim of this paper is to test the different explanations for the origin of the alterations found on the Richmond Hill lithic materials in order to propose the most likely explanation.

The features which lead one to believe that the samples may be geofacts include (1) a lack of technological complexity; (2) the wide spatial distribution of the cert over a $5 \mathrm{~km}$ area and (3) a 1ack of positively identified and associated cultural materials from the test pits, although this could be the result of limited site sampling.

The major factors supporting the hypothesis that the lithic materials are 
artifacts include (1) the lack of evidence for a high energy environment in the vicinity, other than human force, that can account for the various types of fractures and striations found on the lithic objects; and (2) the patterns of breakage, polish and striations are similar to those often found on lithic artifacts and are not expected to appear on naturally fractured geofacts.

Three steps were taken in attempting to solve this problem. The first step was to reconstruct the past geological and weathering environments of the area. This step was directed at discovering evidence for and against a natural high energy environment, powerful enough to have produced the extreme flaking found on some samples of the collection. Fluvial action would have been the most likely of these processes, although heat fracturing causing spalling is another possibility. The second step was to describe and categorize the kinds of alterations observed on the lithic collection, and the third step was a statistical analysis to determine if patterns of the alterations might be similar to those patterns which could be expected to appear on artifacts of human manufacture and use.

\section{SITE DESCRIPTION}

The site of Richmond Hill occurs on a flat stretch of land which was, until 1972, completely covered by tropical forest vegetation. The chert deposits extend for at least five kilometers in diameter in a noncontinuous surface distribution (Puleston 1975:3). However, my concern here is with one small area which I will refer to as the site of Richmond Hill.

The site was first discovered by David Penn, an agronomist and pasture development officer for the Belizean government who was inspecting some newly cleared land late in 1972. He reported his find to Dr. Dennis Puleston who was working in the area on a survey of early Maya riverine agriculture. Puleston was able to examine the site in 1973. He paced out the site's boundaries, collected a surface sample, and excavated a one meter test pit. In August of 1974, he excavated another one meter test pit 25 $\mathrm{cm}$ north of the first.

Normal7y, spatial distribution should be an important factor in the consideration of whether a collection of lithics are truly human artifacts. In the case of Richmond Hill, however, it is possible that the original spatial orientation has been changed through time. The distribution of the lithic materials throughout the stratigraphic profile exhibits a pattern of small flakes and nodules at the top of the profile with Targer ones below. This can be explained in terms of natural processes when considering the high shrink-swell capacity of clayey soils. During repeated wetting and drying throughout the tropical year, shrinking and swelling can cause an upward movement of solid materials, as has been shown in cases where fence posts have been pushed upward and out of line (Soil Survey Staff 1960:124). It is my opinion that the smaller materials such as chert flakes would, over a period of time, have been moved upward more rapidly than larger heavier stone materials. The larger stones from the test pits were from lower levels, and the same situation was true for a small post hole sample taken from the flat surface below the knoll. There- 
fore, the present stratigraphy may not be directly reflective of the depositional history of this area.

\section{GEOLOGIC BACKGROUND}

A brief discussion of the deposition of the Richmond Hill 1ithic materials and the Pleistocene geology of northern Belize is necessary. This consideration will aid in explaining the possible natural forces that could have been the cause of the morphological modifications exhibited by the lithic objects.

During the Cretaceous period, deep layers of white limestone were deposited throughout the area of northern Belize. Much of the chert from this area formed within pockets in these limestone deposits (Flores 1952:408). During the Pleistocene, sea levels rose again in the area (Wright et al. 1959:24) and submerged almost the entire region. The possibility was explored that rivers flowing to the sea at this time could have transported chert noduTes to the Richmond Hill area. In their publication called "Land in British Honduras", Wright et al. wrote that rivers draining from the southern highlands deposited a narrow strip of gravel and chert along the re-entrant bay immediately north of the Maya Mountains. However, this is still too far south to account for the occurrence of the chert in the Richmond $\mathrm{Hill}$ area. The only river mentioned by Wright as flowing from the northern area is the Rio Hondo which is described as "... a deep, rather sluggish river draining a 7 imestone watershed. It has probabiy never carried much sediment" (ibid.:25). Therefore, it is unlikely that the Rio Hondo was the cause of chert deposition in the northern regions. This consequently excludes a potential source of fluvial action.

During later times faulting of the coastal shelf caused the uplifting of limestone ridges in the northern areas. These formed troughs which became areas of water collection creating seasonal swamps, and thick deposits of gray clays were accumulated (ibid.).

The possible origins of bajo sediments are discussed by Cowgil1 and Hutchinson (1963:38) in their work done at Bajo de Santa $\mathrm{Fe}$ in the Peten, Guatemala. After determining the chemical composition of the bajo clays and comparing them with residue from the limestone of the surrounding hills, they concluded that the residue from the eroding upland 1 imestone slowly moved onto the valley floor creating the bajo clays. They also found chert nodules which were described as unsorted and unwaterworn (ibid.:38). These, they postulated, originated in the upland areas and eroded from the 7 imestone when the first occupants arrived and cleared the forest cover, about 3000 B.P.

In keeping with the interpretation of Cowgill and Hutchinson, the Richmond Hill bajo chert could have been secondarily deposited after erosion from a 7 imestone source on the uplands, and subsequent slow movement downhi17 along with other colluvium. This hypothes is is favored over that of fluvial deposition on the basis of (1) the lack of direct evidence for river action in the immediate area; (2) the widespread occurrence of 
chert on the uplands similar to those in the bajo, which would not be expected if rivers were the cause of deposition; (3) the Tack of significant water rounding on the lithic objects themselves and (4) their depositional situation within a colluvial soil matrix.

A possible explanation for the stratigraphic appearance of larger stones in the lower portions of the soil profile with the smaller stones near the surface is that the original deposition of chert occurred at a time corresponding to the lower levels of the test pit where the larger stones now occur. According to the model of Cowgill and Hutchinson it would follow that this would have occurred during the period when people were deforesting the upland areas. Deforestation would have enhanced erosion and the chert concretions would have been detached from their source and redeposited with other colluvium in the bajo area. Such easily obtainable chert would have been an attractive resource for $f 1$ int workers. Following reforestation, intensive erosion would have ceased and a slower rate of colluvial accumulation would have prevailed. More recent colluvium would have eventualiy covered the deposits of chert leaving the larger ones, which move more slowly, nearest the bottom. This of course is speculative and many test situations must be devised before definite conclusions can be reached. These would involve finding the chert source on the uplands, discovering evidences of burning for deforestation at an early date and investigation of the capacity of the Richmond Hill bajo soils to selectively move objects upwards through the solum.

\section{DESCRIPTION OF THE LITHIC COLLECTION}

The Tithic objects from Richmond Hill consist, for the most part of a transiucent reddish brown to gray chert, and are in some cases fossiliferous. They range from about six grams to 900 grams in weight. Most of the stones are nodular in form and many have a thick cortex. The 1 ithic material includes (1) nodules from which a series of flakes were removed; (2) stones from which a 71 of the cortex was removed leaving flake scars over the entire surface; (3) a few primary flakes and (4) some secondary flakes. Sample specimens are shown in Figs. 1-3.

The collection was examined by Washington State University geologists Dr. A. John Watkinson, Dr. H. Len Vacher and Dr. W. Frank Scott. They reported that most of the nodules had probabiy not been moved far from their source by natural forces. The evidence for this was (1) their angularity of shape; (2) the thick cortex; (3) the appearance of surface fossil indentations and (4) the surface areas exhibiting tiny bubbles of chert which formed during solidification. Most of these features would have been altered during any substantial transport. Nevertheless some of the stones did have sma11 areas of water smoothing.

Many of the stones have thick patination, and almost all of them exhibit a very high degree of external gloss on areas not covered by cortex. The cause of the gloss was investigated in order to discover clues the weathering environments which have affected the collection, and the possible relationship between such environments and the more pronounced 

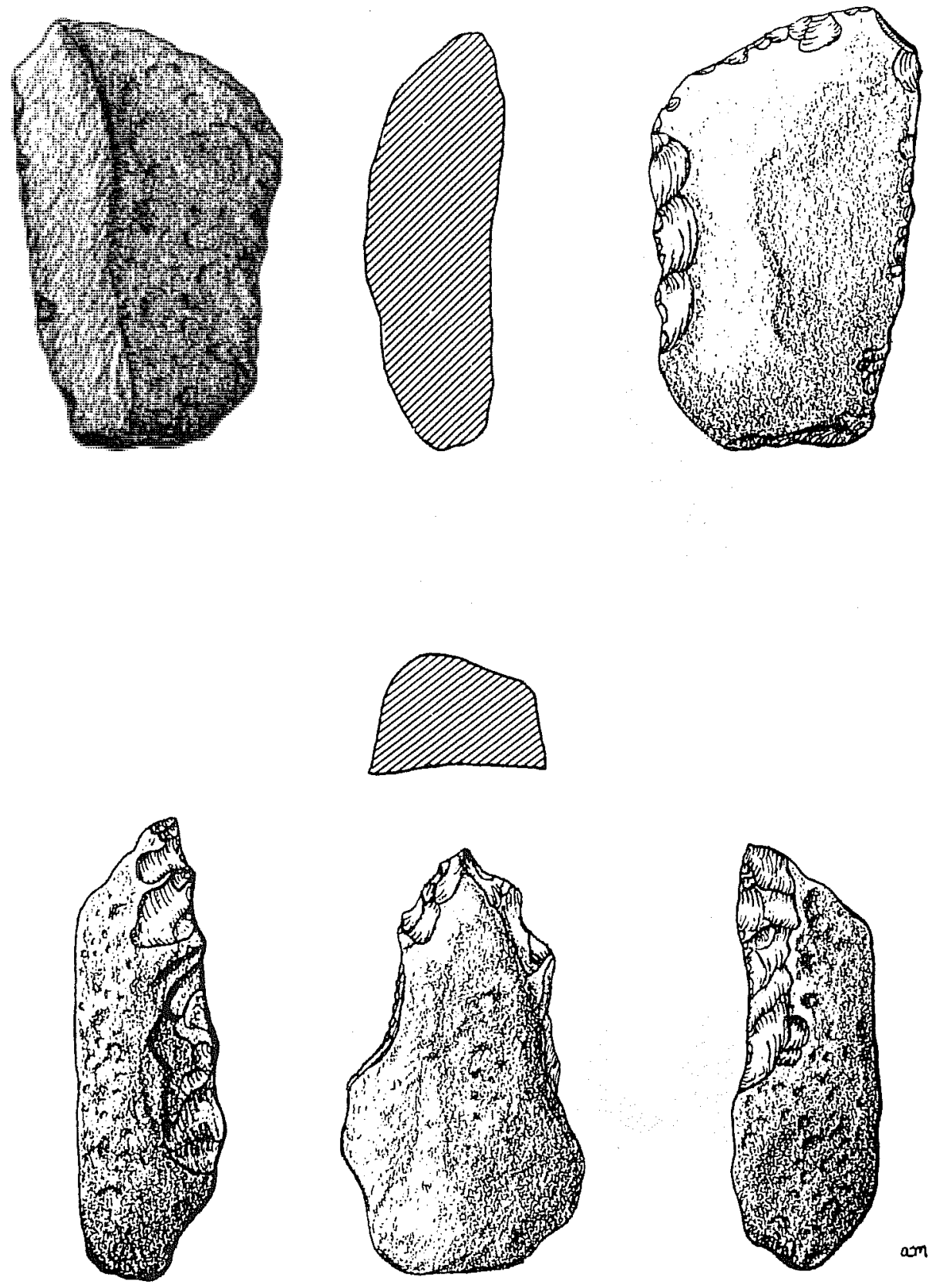

Figure 1. Possible stone artifacts from the site of Richmond Hill (Scale 1:1). 

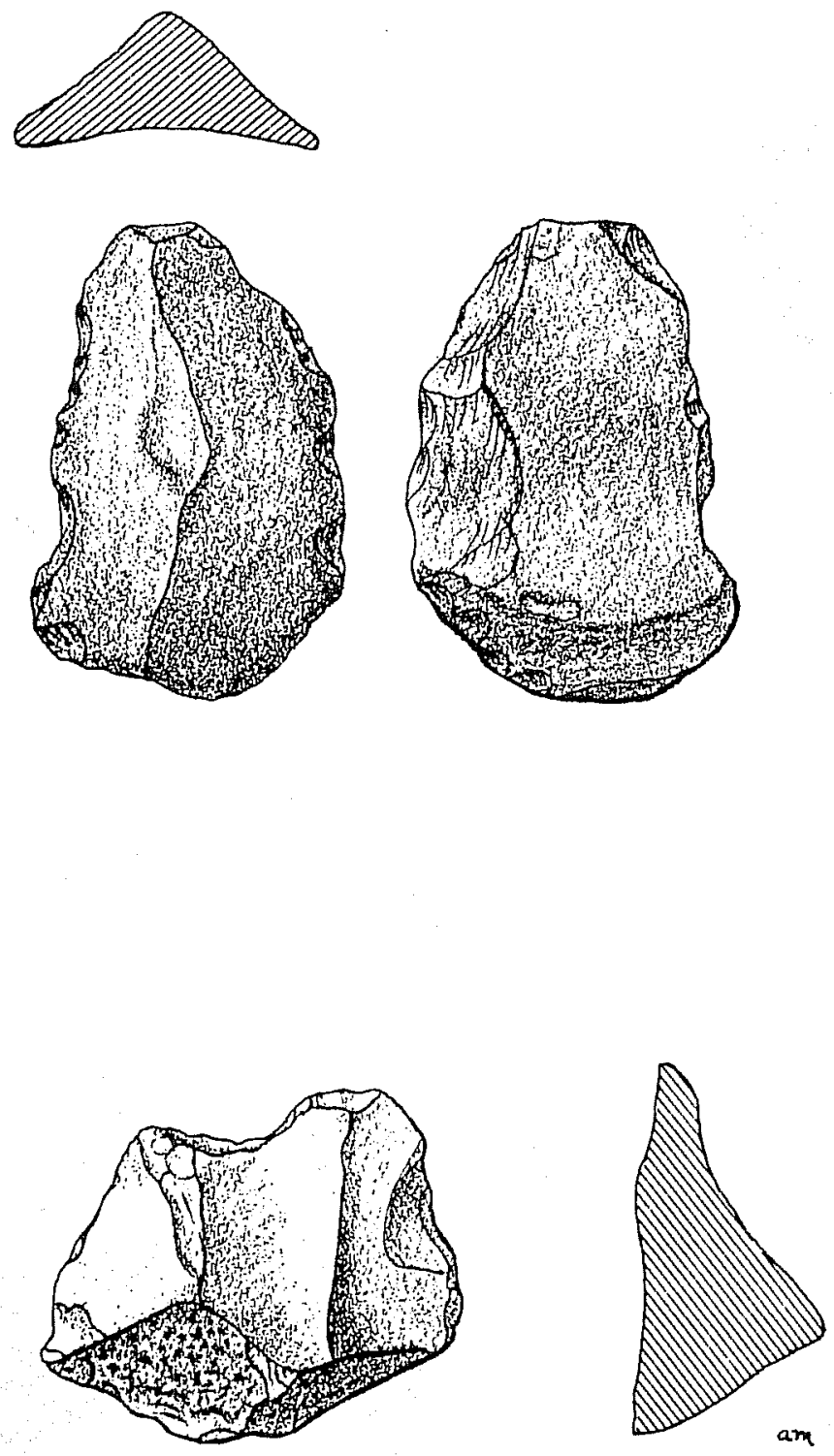

Figure 2. Passible stone artifacts from Richmond Hill. (Scaie 1:1). 

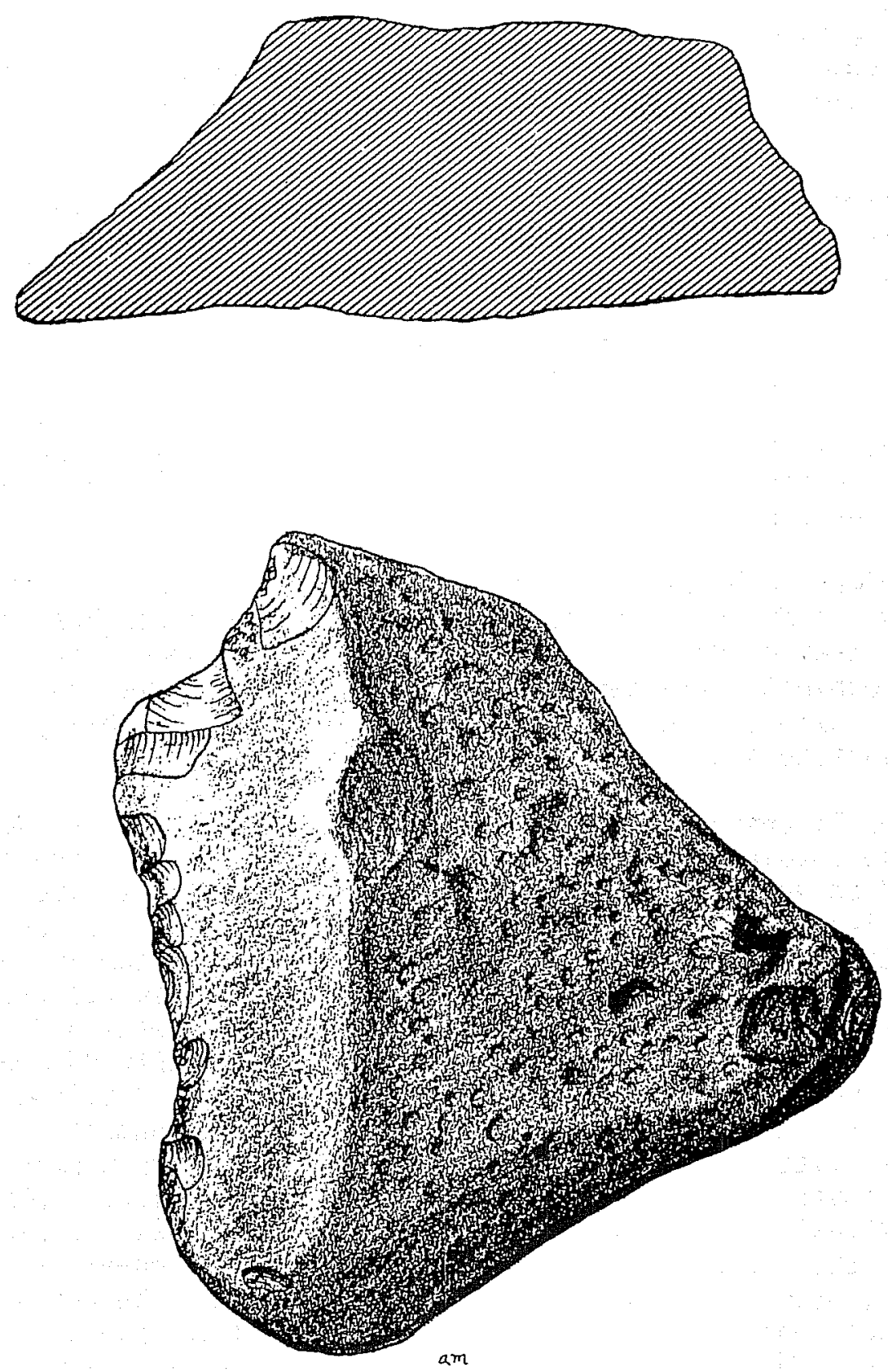

Figure 3. Possible stone artifact from Richmond Hill. (Scale 1:1). 
modifications such as flaking.

This was accomplished with the aid of the scanning electron microscope (SEM). A series of photomicrographs were taken (6000x) of surfaces with gloss ranging in intensity from mildly vitreous to areas of heavily concentrated resinous gloss, or polish. In all cases the results were very much the same. Even at 6000x there were 1arge areas of smooth surfaces intermixed with areas of rounded pitting (Miller 1975: Figs. 6 and 7$)$.

The gloss was first believed to have been the result of extreme heating of the materials such as would happen during a forest fire. A macroscopic vitreousness was achieved on a sample of the same material through heat treatment. The external surface of the stones appeared unchanged in texture but much whiter in color. When flaked, however, the interior exhibited a high degree of vitrification. The opposite is true with the Richmond Hill 1 ithic materials as the interior displays a coarse surface in contrast to the glossy exterior. This gloss also appears on small areas interspersed within the cortex which could not have resulted from flaked exposures.

The SEM photomicrographs of the interior portion of the heat treated materials show a flatter relief than the freshly flaked non-heated materials, but they do not have the large surfaces of smoothing that the natural gloss exhibits. Evidence will be discussed below which suggests these materials were in fact heated. However, this was probably not the cause of the surface gloss.

A review of the literature has revealed comparative samples from geological studies. These studies have investigated the different microscopic surface features found on quartz sand grains which had been subjected to various weathering environments. Since chert has some properties similar to those of quartz such as silica content and hardress, the comparisons are in part justified. Various authors have studied these features, but the work of Krinsley and Funnell (1965) is especially useful as it contains the results of a systematic study of the surfaces of quartz sand grains, utilizing SEM photomicrographs. Their results show that distinct surface patterns are related to different depositional and environmental conditions (e.g., glacial, littoral, aeolian, and diagenes is in which chemical etching predominates). Through the comparison of photomicrographs it was discovered that the chemical etching pattern alone has a striking resemblance to the surface texture of the Richmond Hill chert. According to the authors, quartz dissolves as silicic acid and may be redeposited as colloidal gel, opal, or crystalline quartz depending upon concentration, $\mathrm{pH}$, temperature, and pressure. This causes a wavy etched pattern and a worn, low relief on the surface of the stones, appearing as a gloss macroscopically. Thus, it is probable that the vitreousness observed on the Richmond Hill samples is a result of the present situation within a seasonal swamp. Possibly, periodic water saturation causes the generation of silicic acid and etching, and upon dehydration there is a redeposition of siliceous materials causing the smoothing or gloss. 
The occurrence of round spalls or potlids provides evidence suggesting that heating of these stone materials did take place at one time. It is interesting to note that the surfaces of the potlid cavities are all well glossed indicating that heating of the materials occurred before the glossing. This would tend to support the hypothes is of the burning of the upland forest and subsequent deposition of 1 ithic materials within the bajo below. It is unknown whether the heating was caused by natural or human factors but it seems unreasonable that heat spaling alone could account for all of the kinds of alterations including striations, serial chipping, cores with long flake scars over the entire surface, etc.

\section{Analysis of Alterations}

In order to better understand the causes contributing to the alteration of the Richmond Hill lithic assemblage, a statistical study was conducted to determine which, if any, characteristics of these modifications interrelate with one another in a significantly patterned manner. It is the assumption here that certain patterns could not be expected to occur consistently in nature. This would provide further support for the hypothesis that at least some of the 1ithic objects were of human manufacture. There were 34 different characteristics noted for each damage unit (Miller 1975:24-28). A damage unit may be defined as a discrete area such as an edge, face, ridge, tip, etc., which has undergone stresses that have altered the original form of the stone at that location. A single stone may have from one to five such units. Only a few of these characteristics were found to be significantly related.

The basic assumption of this analysis was that alterations to the lithic objects would be in the form of clusters of characteristics which could be attributed to specific causes. For example, a given task, tool modification technique, or weathering environment would consistently leave specific groups of characteristics. If groups of these characteristics could be recognized in an assemblage, perhaps then, it would be possible to narrow down the types of activities which had caused these groups. Assuming that a 11 members of the collection were exposed to equal weathering environments under natural conditions, the null hypothesis was that all characteristics of alteration occur on the samples with equal frequencies due to the uniform effect of environmental variables.

The sample consisted of 86 individual stones, and from this 224 damage units were recorded. Most of the statistical tests were run on the damage units considering them as single entities independent of the whole stone. Of the 34 characteristics tested, only those of polish, stria, and retouch were found to be significantly related. These were perhaps the most objectively defined categories of stone modification.

Chi-square tests were run to investigate the co-occurrence of specific characteristics. The test on the presence or absence of polish and striae on the 86 individual stones demonstrated their common occurrence at the .01 level of probability (Table 1). This relationship could indicate human use as the agency which modified the stones. Both polish and striations often occur together in tool use with concentrated pressure and small quartz grains which come between the working surface of the 
stone and the object being processed (Semenov 1964:84; Wi1msen 1970:71).

Another statistical relationship which presents evidence against solely natural causes of alteration was the direction of the striae (parallel, perpendicular, multidirectional, etc., in relation to the nearest edge) and its occurrence on only one face as opposed to various faces (Table 2). Assuming that all faces of a given stone, under purely natural conditions, were equally subjected to stresses causing striations, one would expect the same frequencies of occurrence for the different directions as found on multisurfaces. This, however, is not the case with the Richmond Hill materials. A chi-square test run with the variables unidirectional or multidirectional, on one face or two faces, was significant at the .02 level of probability indicating a non-random relationship with unidirectional striations more common on one face rather than on multiple faces. This could also be indicative of human use (Tringham et al. 1974:188-189, 192).

When striae and retouch were found together in association on one damage unit, the retouch was most often on the lateral surface with the striations most often on the ventral face. This is also a common situation on lithic implements since retouching may be used to dull the lateral surface so that the tool can be easily held when using a portion of the ventral face as the working surface (Semenov 1964:64; Wilmsen 1970:70). A chi-square test considering all locations of striae and all locations of retouch resulted in a .05 level of significance for this correlation (Table 3 ). The number of damage units which have both striae and retouch was only 17, and therefore may not be a reliable sample, nevertheless the results do merit cautious speculation.

When the retouch was located on the lateral surface, the striations were found to be mostly oriented toward the damage units in multidirectional and perpendicular directions. This correlation was significant with a .005 level of probability when tested using chi-square (Table 4). Striations perpendicular to the edge indicate a single direction of movement as might be expected on end scrapers, or for an adzing activity (Wilmsen 1970:74). Multidirectional striations are often found on scraping tools (Semenov 1964:83).

These tests, although somewhat 1 imited and unsupported by replicative experiments, serve to question the null hypothesis that damage characteristics are equally distributed on these lithic objects and therefore lend support to the belief that some of the Richmond Hill samples are, in fact, artifacts. 


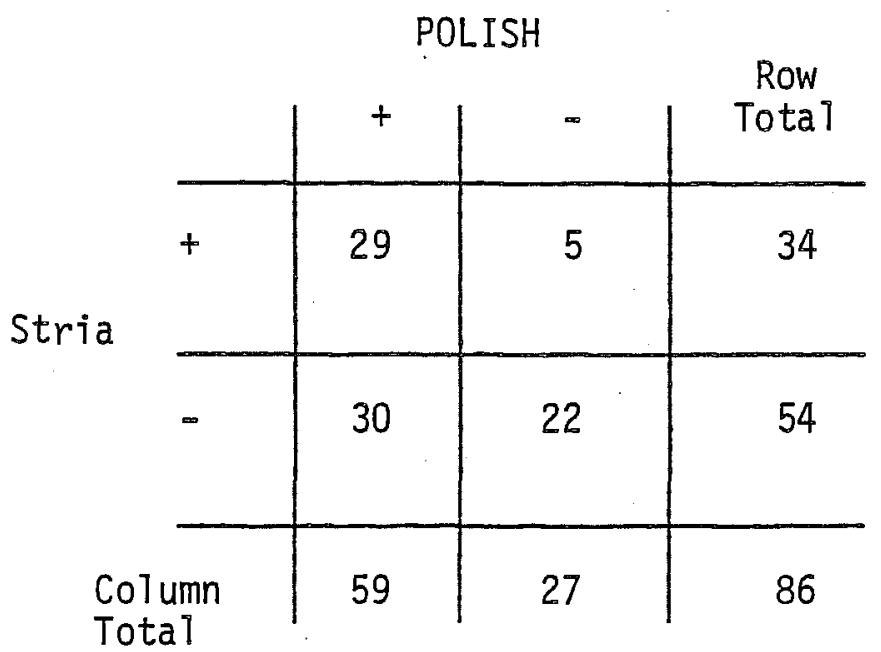

Chi-Square $=7.279$ with 1 degree of freedom. Probability $=.01$

+ , presence

- , absence

Table 7. Chi-square table correlating the presence of polish with the presence of striae on all of the individual stones (Miller 1975).

\section{STRIA DIRECTION}

\begin{tabular}{|c|c|c|c|c|}
\hline & & $\begin{array}{c}\text { unidirec- } \\
\text { tional }\end{array}$ & $\begin{array}{c}\text { multidirec- } \\
\text { tional } \\
\end{array}$ & $\begin{array}{l}\text { Row } \\
\text { Tota } \\
\end{array}$ \\
\hline & $\begin{array}{l}\text { On One } \\
\text { Face }\end{array}$ & 11 & 6 & 17 \\
\hline ON & $\begin{array}{l}\text { On Two } \\
\text { Faces }\end{array}$ & 2 & 9 & 11 \\
\hline & $\begin{array}{l}\text { Column } \\
\text { Total }\end{array}$ & 13 & 15 & 28 \\
\hline
\end{tabular}

Chi-Square $=5.425$ with 1 degree of freedom. Probability $=.02$

Table 2. Chi-square table correlating the direction of striae with location for all individual stones possessing stria (Miller 1975). 
on ventral

\begin{tabular}{c|c|c|} 
ventral & dorsal \\
\hline 0 & 0
\end{tabular}

ventra and dorsal

0

$\left.\right|^{\text {two }}$

on dorsal

on lateral

on face

ICATION

on flake scar

on Tateral

presence

suspected

COLUMN

TOTAL

\begin{tabular}{|c|c|c|c|c|c|c|}
\hline 0 & 0 & 0 & 0 & 0 & 1 & 1 \\
\hline 0 & 0 & 0 & 1 & 1 & 0 & 2 \\
\hline 0 & 0 & 1 & 0 & 1 & 1 & 3 \\
\hline 0 & 0 & 1 & 0 & 0 & 0 & 1 \\
\hline 1 & 0 & 0 & 0 & 0 & 1 & 2 \\
\hline 0 & 1 & 0 & 0 & 0 & 0 & 1 \\
\hline 1 & 1 & 4 & 1 & 2 & 8 & 17 \\
\hline
\end{tabular}

Chi-Square $=43.66360$ with 30 degrees of freedom. Probability $=.05$

Table 3. Chi-square table correlating the location of retouch with the location of striae as they occur together on individual stones (Miller 1975). 
RETOUCH LOCATION

\begin{tabular}{|c|c|c|c|c|c|c|c|}
\hline & ventral & dorsa 1 & $\begin{array}{c}\text { ventral } \\
\text { and dorsal } 1\end{array}$ & one face & two faces & lateral & $\begin{array}{r}\text { ROW } \\
\text { TOTAL }\end{array}$ \\
\hline diagonal & 0 & 0 & 0 & 0 & 1 & 1 & 2 \\
\hline parallel & 0 & 0 & 0 & 1 & 0 & 0 & 1 \\
\hline perpendicular & 0 & 0 & 2 & 0 & 0 & 3 & 5 \\
\hline multidirectional & 0 & 0 & 0 & 0 & 1 & 3 & 4 \\
\hline wrinkling & 0 & 0 & 1 & 0 & 0 & 1 & 2 \\
\hline $\begin{array}{l}\text { presence } \\
\text { suspected }\end{array}$ & 0 & 1 & 0 & 0 & 0 & 0 & 1 \\
\hline $\begin{array}{l}\text { perpendicular } \\
\text { and diagonal }\end{array}$ & 1 & 0 & 0 & 0 & 0 & 0 & 1 \\
\hline $\begin{array}{l}\text { perpendicular } \\
\text { and parallel }\end{array}$ & 0 & 0 & 1 & 0 & 0 & 0 & 1 \\
\hline $\begin{array}{l}\text { COLUMN } \\
\text { TOTAL }\end{array}$ & 1 & 1 & 4 & 1 & 2 & 8 & 17 \\
\hline
\end{tabular}

Chi-Square $=60.88107$ with 35 degrees of freedom. Probability $=.005$

Table 4. Chi-square table correlating the location of retouch with the direction of striae relative to an individual edge (Miller 1975). 


\section{CONCLUSION}

It has been the aim of this paper to determine whether the formal alterations exhibited by the Richmond Hill lithic objects were caused by human manufacture and use as implements. It is argued here that the data presented supports this possibility.

Fluvial action as a cause of damage was rejected as there is no evidence for sediment-carrying rivers in this area from Pliocene to recent times. Also, there are few macroscopic properties indicating water transport over long distances. In addition, microscopic examination of the glossy surface texture on the stones did not show the type of scarring expected to occur in a fluvial environment. Heat spalling, although present, was rejected as a major cause of alteration since it could not account for all varieties of modification, and in particular striations.

Stratigraphic and depositional positioning should be an important factor in determining human presence archaeologically. However, it was demonstrated here by a discussion of the stratigraphy and soil matrix that the original deposition may have been disturbed by the seasonal expanding and contracting of clayey soils. It was suggested that these processes were probably also responsible for creating the knolls found at the site.

Characteristics of the damage features on the stones were noted, and chisquare tests were run to determine if these characteristics related to one another in a patterned manner which would be similar to common patterns found on lithic artifacts. Of all 34 characteristics only those of polish, striae, and retouch were found to be significantly related. These are probably the most distinct and objective of all the categories.

The above investigations have led to the following interpretation of the depositional history and alterations of the lithic objects of Richmond Hi11: the lithic materials originally formed as chert deposits within limestone, near the area of the present site, sometime before the Pliocene. During the Pleistocene, coastal faulting caused the uplifting of the chert bearing limestone creating depressions and seasonal swamps below. The natural forest cover on the uplands kept erosion to a minimum. When the first human populations arrived, the forest was burned to create agricultural land. This resulted in the heat spalling of the lithic materials which were situated close to the surface. Continuous clearing of the upland forest would have caused rapid erosion of the normally thin soil under the heavy tropical rains. Erosion of soil, and the naturally soft limestone beneath it, would have freed the chert from its parent rock and allowed it to wash down the slopes along with other colluvium to the bajo below.

This concentration of easily attainable fine grained 1 ithic material would have attracted flint workers to the bajo areas in order to manufacture and use implements from this material. Perhaps the implements were used in the harvesting of some other bajo resources as well. 
At least two explanations are possible for the lithic depositional sequence in which the large stones are located deep with in the profile, and the small stones are near the surface. First, all of the stones were initially deposited together after erosion from the same general source. After reforestation of the uplands, colluvial deposits consisted of only clay sediments which built up over the original level. Over time, the shrink-swell action of the accumulated bajo clays moved the lithic materials upwards towards the surface with the smaller stones moving the fastest and consequentiy occupying the upper portions of the stratigraphic profile. A second explanation could be that since shifting agriculture on the uplands caused burning and deforestation in many different places, several different chert sources were exposed and washed down the slopes at different times. The lower profile then would correspond to a source of large nodules and the upper portion to a source of smal1 nodules. Support for one of these explanations might be gained with the use of neutron activation analysis in an attempt to pinpoint the lithic material to one or several sources.

To test all of the above interpretations several steps should be taken. These include:

1) a search for primary chert sources on the upland areas

2) find evidence for early extensive burnings on the uplands

3) check the topography for evidence of rapid erosion at one point in time

4) survey for other sites on the uplands which relate to the Richmond Hill site in the bajo

5) examine the tiny chips of chert not previously recovered at the bajo site for evidence of detritus from implement manufacture

6) test the shrink-swell capacity of the bajo soil and its ability to move objects upwards in the profile.

In conclusion, it is probable that the Richmond Hill lithic objects were not naturaliy fractured, and may instead be either a feature of the Classic Maya lithic technology, or the remains of some of the earlier inhabitants of the tropical lowlands of Central America. Very Tittle is known about early populations in this area and their relationship to other early inhabitants of Mesoamerica. Therefore, the Richmond Hili site needs to be further and systematicaliy investigated.

\section{ACKNOWLEDGEMENTS}

I would like to express my gratitude to Dr. Dennis Puleston for making the Richmond Hill lithic collection fully available, and for his generous assistance and advice. I am indebted to many individuals for advice and 
instruction in connection with this paper. I would especially like to thank Dr. Henry Irwin, Dr. Fekri Hassan, Dr. Frank Leonhardy, Dr. Robert Littlewood, Dale Croes, and Susan Kent, Department of Anthropology, Washington State University, Dr. A. John Watkinson, Dr. H. Len Vacher, and Dr. W. Frank Scott, Department of Geology, Washington State University, who gave generously of their time and the use of their equipment.

\section{REFERENCES CITED}

Barnes, A. S.

1939 The Differences Between Natural and Human Flaking on Prehistoric Flint Implements. American Anthropologist $41: 99-112$.

Carter, G. F.

1967 Artifacts and Naturifacts: Introduction. Anthropological Journal of Canada 5(1):2-5.

Clark, J. D.

1958 The Natural Fracture of Pebbles from the Batoka Gorge, Northern Rhodesia, and its Bearing on the Kafuan Industries of Africa. Proceedings, Prehistoric Society 34:64-77.

Cowgi11, Ursula M. and G. E. Hutchinson

1963 El Bajo de Santa Fe. Transactions of the American Philosophical Society 53:1-51.

Flores, Giovanni

1952 Geology of Northern British Honduras. Bulletin of the American Association of Petroleum Geologists 36:404-413.

Harner, M. J.

1956 Thermo-facts vs. Artifacts: An Experimental Study of the MaTpa is Industry. University of California Archaeological Survey Reports $33: 39-43$.

Heider, K. G.

1960 A Pebble-Tool Complex in Thailand. Asian Perspectives 2(2): 63-68.

Krinsley, David Henry and Brian Michael Funne11

1965 Environmental History of Quartz Sand Grains from the Lower and Middle Pleistocene of Norfolk, England. Geological Society of London, Quarterly Journal 121:435-461. 
Miller, Arlene V.

1975 A Study of Possible Explanations for Observed Damage on the Lithics from the Site of Richmond Hill, Belize. Unpublished MA research paper, Department of Anthropology, Washington State University.

Puleston, Dennis E.

1975 Richmond Hi17: A Probable Early Man Site in the Maya Lowlands. Actas, XLI Congreso Internacional de Americanistas I:522-533.

Rose, F. P.

1968 A Flint Ballast Station in New Rochelle, New York. American Antiquity 33:240-243.

Semenov, S. A.

1964 Prehistoric Technology, An Experimental Study of the Oldest Artifacts from Traces of Manufacture and Wear. Adams and Dart, Bath.

Soil Survey Staff

1960 Soil Classification, A Comprehensive System (7th Approximation) U.S. Department of Agriculture, Soil Conservation Service.

Tringham, Ruth, Glenn Cooper, George Ode11, Barbara Voytek, and Anne Whitman

1974 Experimentation in the Formation of Edge Damage: A New Approach to Lithic Analysis. Journal of Field Archaeology $1: 171-195$.

Wilmsen, Edwin N.

1970 Lithic Analysis and Cultural Inference: A Paleo-Indian Case. Anthropological Papers of the University of Arizona 16.

Wright, A. C. S., D. H. Romney, R. H. Arbuckle, and V. E. Vial

1959 Land in British Honduras. Colonial Research Publication 24. Her Majesty's Stationery Office, London. 
AN OBSIDIAN WORKSHOP AT EL POZITO, NORTHERN BELIZE

Mary Neivens and David Libbey

INTRODUCTION

In recent years in Mesoamerican archaeology there has been a growing concern with craft specialization, evidenced by such papers as those of Adams (1970), Becker (1973) and Millon (1970). In view of such concern we are providing this report of our discovery during the 1976 field season of an obsidian workshop at El Pozito, the first such workshop to be found in Belize.

E1 Pozito (Fig. 1) is a 1arge ceremonial center (Bullard 1960:360) with a predominantiy Late Classic component. The site is composed of two ceremonial precincts with several hundred surrounding house mounds. The 1976 field season was the third season of excavations. The primary goal in excavation of the site has been to determine the subsistence-settlement pattern with a view to incorporating it into the regional studies that are now being carried on in northern Belize (see Hammond 1973, 1974 and Siemens 1974). The program at El F'ozito is being carried out in two major categories. The first is an extensive mapping of the man-made structures and topography in the area of the settlement that is connected to the ceremonial precincts. At present the areal extent covers nine square kilometers. The second is an excavation program that has concentrated on test pitting for a chronological sequence encompassing both the ceremonial areas and the house mounds as wel1 as a search for activity areas. The principal findings of the first two seasons indicate that El Pozito was a large regional center during the Late Classic Period. Over $90 \%$ of the house mounds that were tested or surface collected were occupied during the Late Classic. The excavations of the 1976 season were concentrated on a randomly selected sample of domestic structures within several prominent plazuela groups to further our understanding of the population distribution. It was in one such randomly selected structure--a long, low mound forming part of a group to the northwest of the main ceremonial center--that the remains of an obsidian workshop were found (Fig. 2).

\section{EXCAVATION}

The remains of the obsidian workshop were discovered in Level 2 of a two meter square test pit, between two parallel walls which may or may not have belonged to the same structure (Fig. 3). The top of the first wall lay along the south face of the pit on an axis of $575^{\circ} \mathrm{E}$; the upper portion of its vertical face was plastered. The second wall uncovered along the north face of the excavation was also plastered on the upper portion of its vertical face. After the walls were exposed, the excavation was narrowed to the space confined by them. Between the walls, obsidian debitage began at $18 \mathrm{~cm}$ below the ground surface in the eastern half of the pit. A 1/16 inch mesh screen was set up for complete recovery. The debitage increased in density as the excavation continued, and it formed a distinct concentration at $50 \mathrm{~cm}$ below ground surface. Along the west face of the excavation marl blocks rested on the uneven sascab (a natural 1 ime cement) 


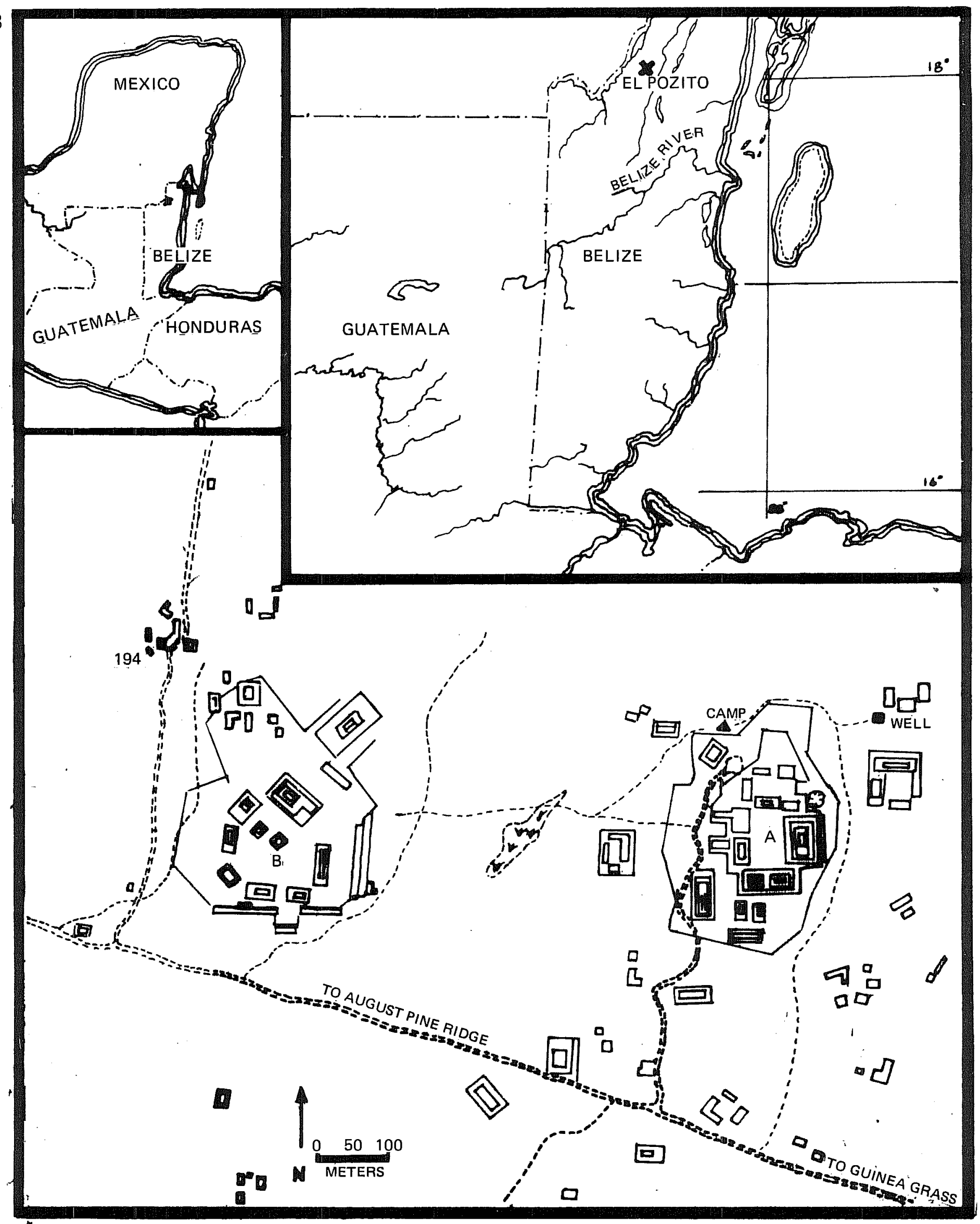

Figure 1. Sketch map showing the relationship of Mound 194 to the ceremonial precincts. Insets show location of ET Pozito and Belize. 
EL POZITO PLAZUELA GROUP

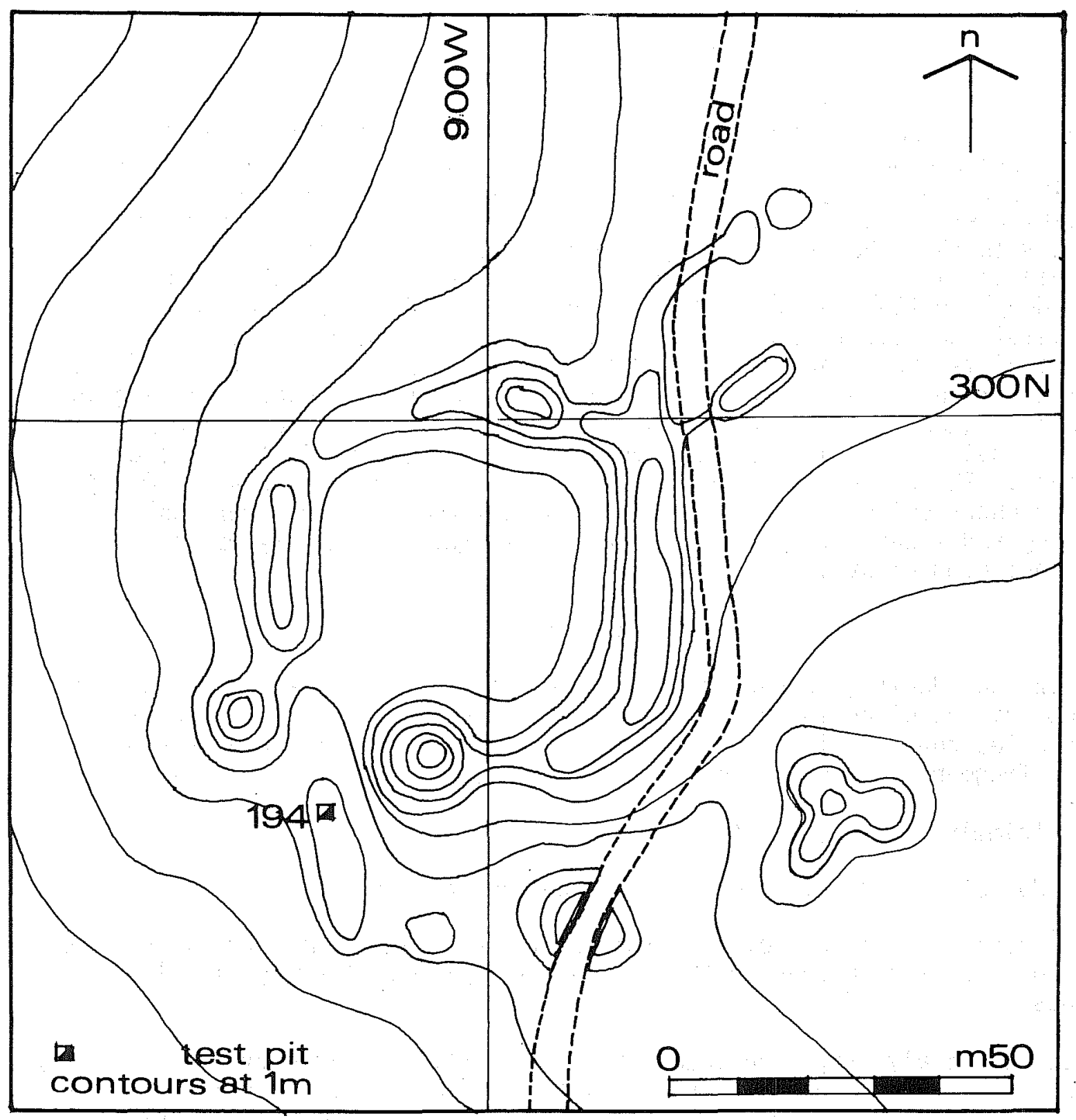

Figure 2. Topographic map of the plazuela group with the obsidian workshop. 
surface of Level 3. The plaster on the sides of the walls terminated at Leve1 3. The packed sascab extended to Level 4 or the base of the two walls. The concentration of obsidian had begun to dwindle with Level 3 , and in the upper portion of Level 4 , a we11-consolidated white marl, the last of the obsidian debitage occurred. Level 5, a dark organic layer, was the original ground surface, underlain by the 7 imestone bedrock that is predominant in the area.

\section{ASSOCIATED ARTIFACTS}

With the obsidian debitage were found a chert chisel (Object 6), stone fragments (0bjects 2, 4 and 5), a large pottery sherd (Object 3), and a deteriorated bone (not illustrated) which may have been a flaking tool, possibly a punch (Fig. 4). Object 1 (not illustrated), a fine grained polishing stone, was found very near the surface and not in direct association with the other tools. Object 2 is a portion of a metate found in two pieces with object 3 sandwiched between them. The metate fragment is of a deeply pitted coarse-grained igneous rock. Deterioration made it impossible to determine any wear pattern on its surface. Between the two pieces of metate a large rim sherd (object 3) from a polychrome round sided bow 1 was found. The edges of the sherd are smoothed. Object 4 is a granite metate fragment. It did not show the highly polished surface of object 1 and 5 . Object 5 is a fine grain volcanic stone with a highly polished surface. The center of the stone shows a concave honing surface. Object 6 , the chert chisel, is similar to examples from Tikal that were used for cutting and shaping 1 imestone or marl blocks (Hattula Moholy-Nagy, personal communication).

\section{DEBITAGE ANALYSIS}

In size the debitage ranges from $60 \mathrm{~mm}$ pieces to $3 \mathrm{~mm}$ flakes. A total of 12,082 pieces of obsidian was recovered in the excavation. The debitage categories consist of polyhedral core fragments, prismatic blades and blade fragments, retouched blades and flakes.

Core Trimming and Rejuvenation Flakes

No. of specimens: $180 ; 1.5 \%$ of the sample (Fig. 5)

These flakes resulted from the removal of protruding lumps and ridges from the core, a step in shaping the core prior to the continued removal of blades.

These relatively large and chunky flakes are characterized by well-developed bulbs of percussion on the ventral surface. On the dorsal surface, flake scar ridges extend along the long axis of the flake. On some of the examples these side ridges alternate from one side to the other as they move down the central axis (Fig. $5 \mathrm{a}-\mathrm{c}$ ); some of these specimens may be crested, or ridge, blades.

The flakes range in size from $20 \mathrm{~mm}$ long by $7 \mathrm{~mm}$ wide by $4 \mathrm{~mm}$ thick (at the thickest point along the medial ridge and the ventral side) to $49 \mathrm{~mm}$ 


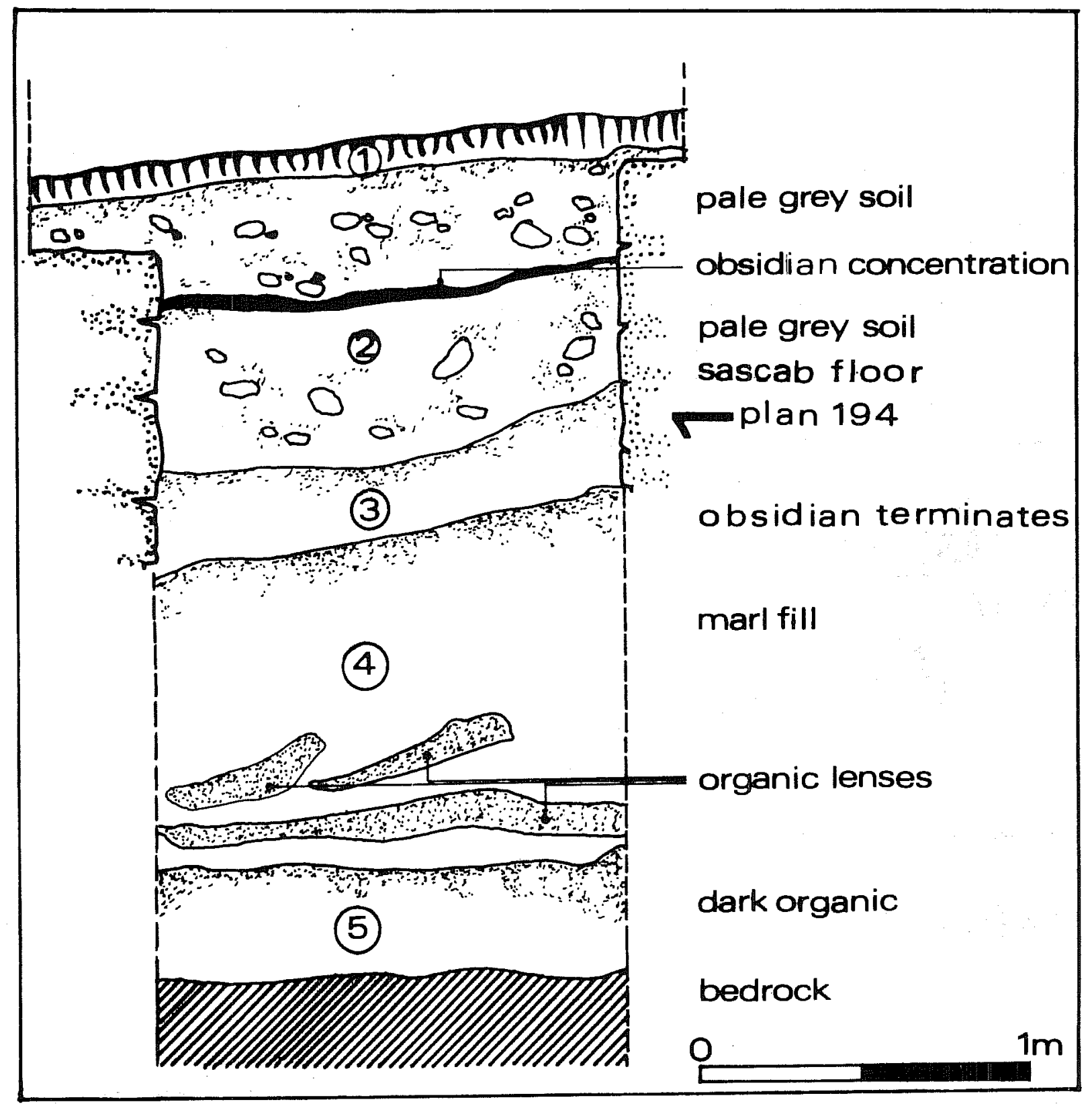

Figure 3. East section through test pit, Mound 194. 

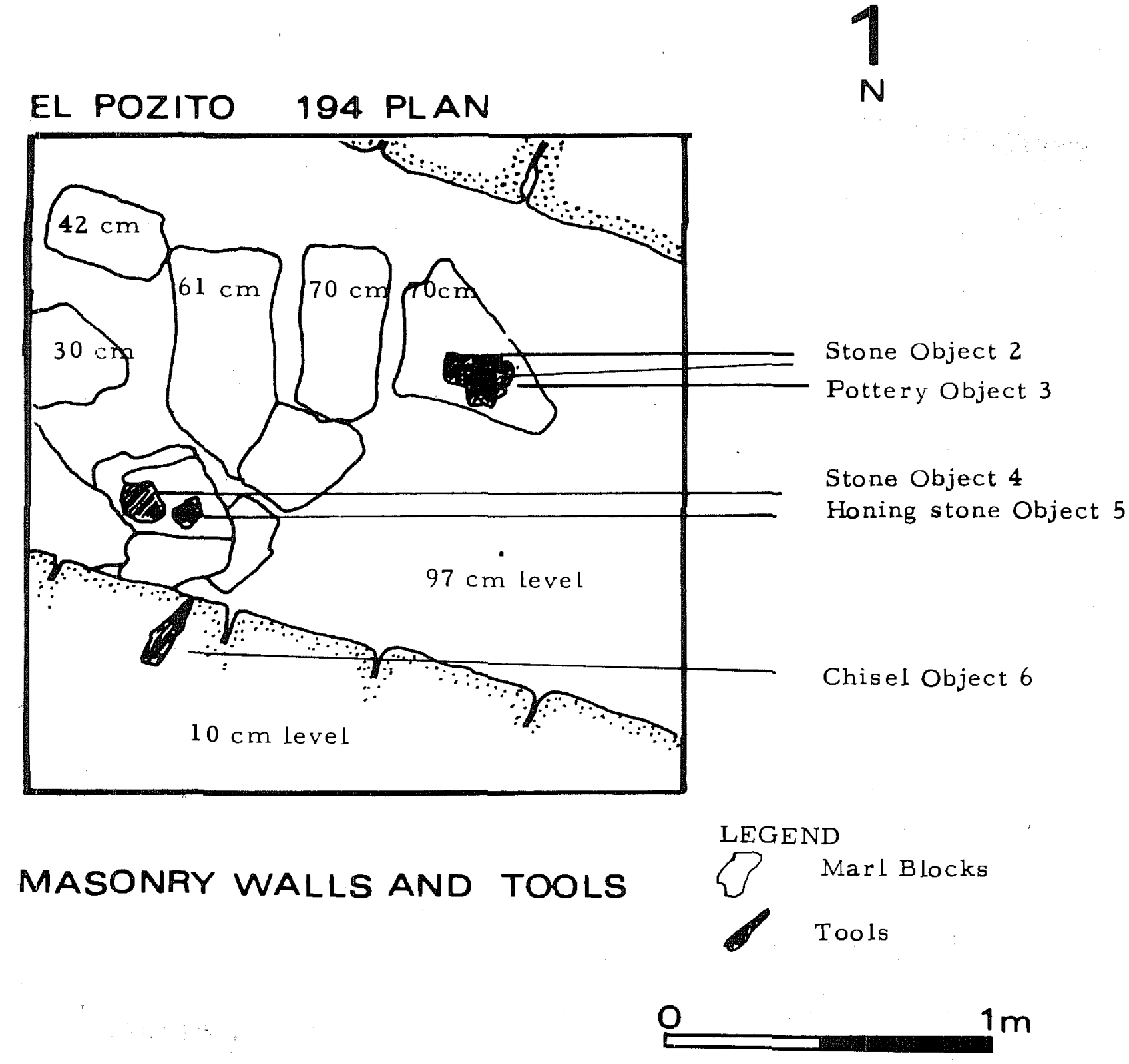

Figure 4. A plan of the obsidian workshop in Mound 194. 
long by $29 \mathrm{~mm}$ wide by $7 \mathrm{~mm}$ thick.

Many of these flakes show crushing along the ridges, the result of percussion removal (Fig. 5 d). Eighty-four specimens show eraillure flake scars (Fig. $5 \mathrm{~b}-\mathrm{c}$ ) on the ventral side of the bulb, another result of percussion removal. One hundred eleven examples have grinding along the dorsal ridge, evidence of wear during transport, or possibly use. One example is notched, with flake removal from the dorsal side.

Eraillure Flakes

No. of specimens: $69 ; .6 \%$ of the sample (Fig. 6)

These flakes are apparently the remains of a bulbar scar (Crabtree 1972: 60). They seem to represent the residue that falls away from a percussion flake during its removal. Relatively small plano-convex flakes, they are generally circular to oval, tapering to a sharp edge around the circumference (Fig. $6 \mathrm{f}-\mathrm{h}$ ). Some have the appearance of a contact lens. They are characterized by compression rings on the ventral (concave) surface. They range in size from $30 \mathrm{~mm}$ to $13 \mathrm{~mm}$ in diameter.

Core Fragments

No. of specimens: $24 ; .2 \%$ of the sample (Fig. 6)

Of these fragments 17 are proximal ends. Tweive of the proximal ends are side angle platform rejuvenation flakes. This rejuvenation is necessary when the core has become constricted or nearly exhausted (Crabtree 1968: 457; Hester, Jack, and Heizer 1971:76). For additional blade removal a larger platform must be made. In this technique, force is applied to the side of the core platform parallel with and about 2 or $3 \mathrm{~mm}$ below the surface of the platform perpendicular to the long axis. If one blow does not clear the platform, then two strokes, one from each side, would remove the old platform and with subsequent grinding and flattening a new platform for continued blade removal would emerge. Only two of the proximal core truncations show efficient clearing of the entire platform, yielding a core tablet (Fig. 6 b). The smallest was approximately $15 \mathrm{~mm}$ in diameter.

Five of the proximal fragments have striations across the edge of the platform for gripping the blade removal tool (in all cases the striations form a triangle with its apex at the ridge formed by the scars from two previous blade removals).

There are seven terminal ends of which two are recovery flakes with step fractures (Fig. 6 a); two were removed with blades; two have bulbs of percussion and so were probably removed purposely; and one is indeterminate.

Blade Fragments

No. of specimens: 11,$815 ; 99 \%$ of the sample (Figs. 5 and 6 )

Only three complete blades were recovered. In Fig. 6,c the dorsal view shows the nearly parallel ridges and the negative compression rings along 
the scars from previous blade removals. The ventral view shows the concave-convex form of the blade. All three blades are similar in length and are "prismatic" with parallel edges and a medial ridge.

The blade fragments are relatively long and thin and broken sometimes with irregular sharp edges (Fig. $5 \mathrm{e}-\mathrm{g}$ ). 5,762 are broken so that they lack bulbs and platforms. Those flakes with a platform have a poorly developed bulb and exhibit a triangular or trapezoidal cross section. A number of the platforms exhibit abrasion or dulling along the edge. 607 examples have fine grinding on the dorsal ridge. Some of these fragments may be the result of core modification rather than the production of an imperfect blade. The smallest of these flakes is $8 \mathrm{~mm}$ long by $16 \mathrm{~mm}$ wide and the largest is $60 \mathrm{~mm}$ long by $11 \mathrm{~mm}$ wide.

Strangulated (Notched) Blades

No. of specimens: 22 ; slightly less than .2\% of the sample (Fig. 6)

These tools were all made on the bulbar end of blade fragments. The European term "strangulated" is applied here for the flaking occurs directly opposite on both margins making a constriction (Crabtree 1972:93). The technique of removing the flakes is characteristic of the tranchet blow whereby the "blow is struck obliquely to the marginal edge to remove a flake crosswise and at right angles to the main axis of the tool, leaving a sharp transverse edge". (Crabtree 1972:95). The notching is done from alternate sides (Fig. $6 \mathrm{~d}, \mathrm{e}$ ) with flakes removed from one margin on the dorsal side and from one margin of the ventral side. Twenty-one blades have this kind of alternate notching, while one example displays two pairs of notches on each side. One blade shows dorsal flaking on both margins on the same side. All of the notched blades have been broken off below the notches at the distal end. The smallest strangulated blade is $7 \mathrm{~mm}$ long by $10 \mathrm{~mm}$ wide (across the bulb). The 7 argest one is $22 \mathrm{~mm}$ long by $10 \mathrm{~mm}$ wide.

Other Retouched Specimens

No. of specimens: 2 ; Tess than . $1 \%$ of the sample

Of the two pieces showing retouch, one is a broken triangular blade with dorsal flaking retouch around the bulbar end. The other is a core rejuvenation flake with ventral flaking along one margin.

CERAMIC ANALYSIS

The levels of the test pit in which obsidian was found produced Late Classic sherds. A substantial portion of the monochromes are of the dark red slip (Munsel1 7.5YR 4/8). The polychromes are also Late Classic characterized at EI Pozito by a matte finish in red-and-black on orange. These polychromes occur in the simple silhouette dishes with and without a lateral ridge that compare to San Jose III (Thompson 1939:100). A large rim sherd reported in the excavation (Fig. 4, Object 3) manifests this polychrome treatment with the matte finish that is so abundant at 

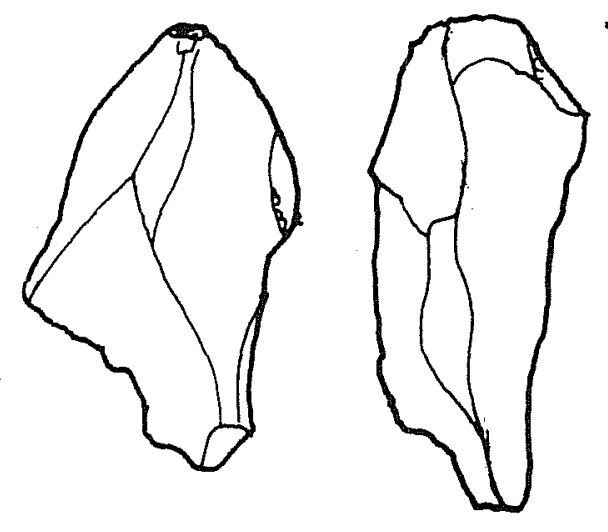

a

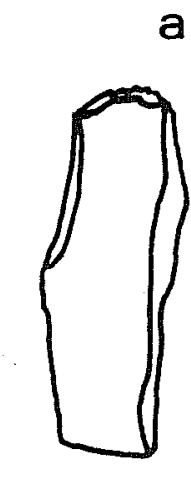

e

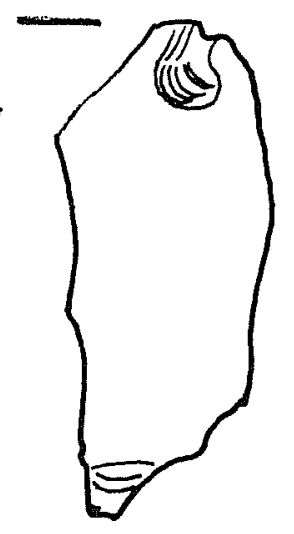

b

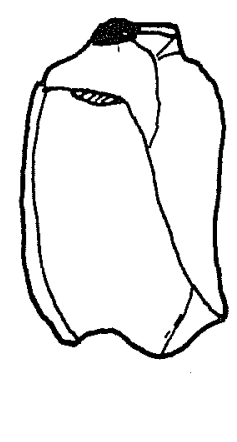

C

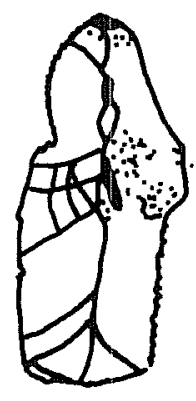

d
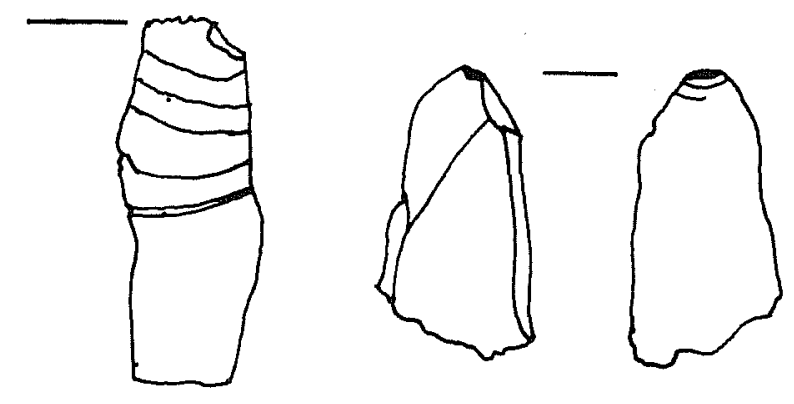

f

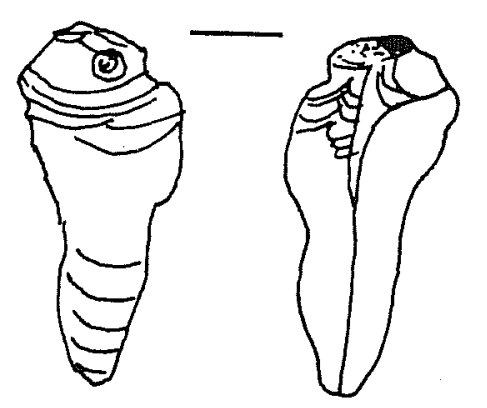

g

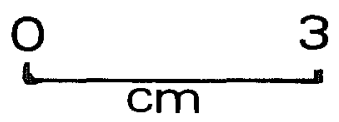

Figure 5. Obsidian debitage from El Pozito. a-d, core trimming and rejuvenation flakes; e-g, blade fragments. 

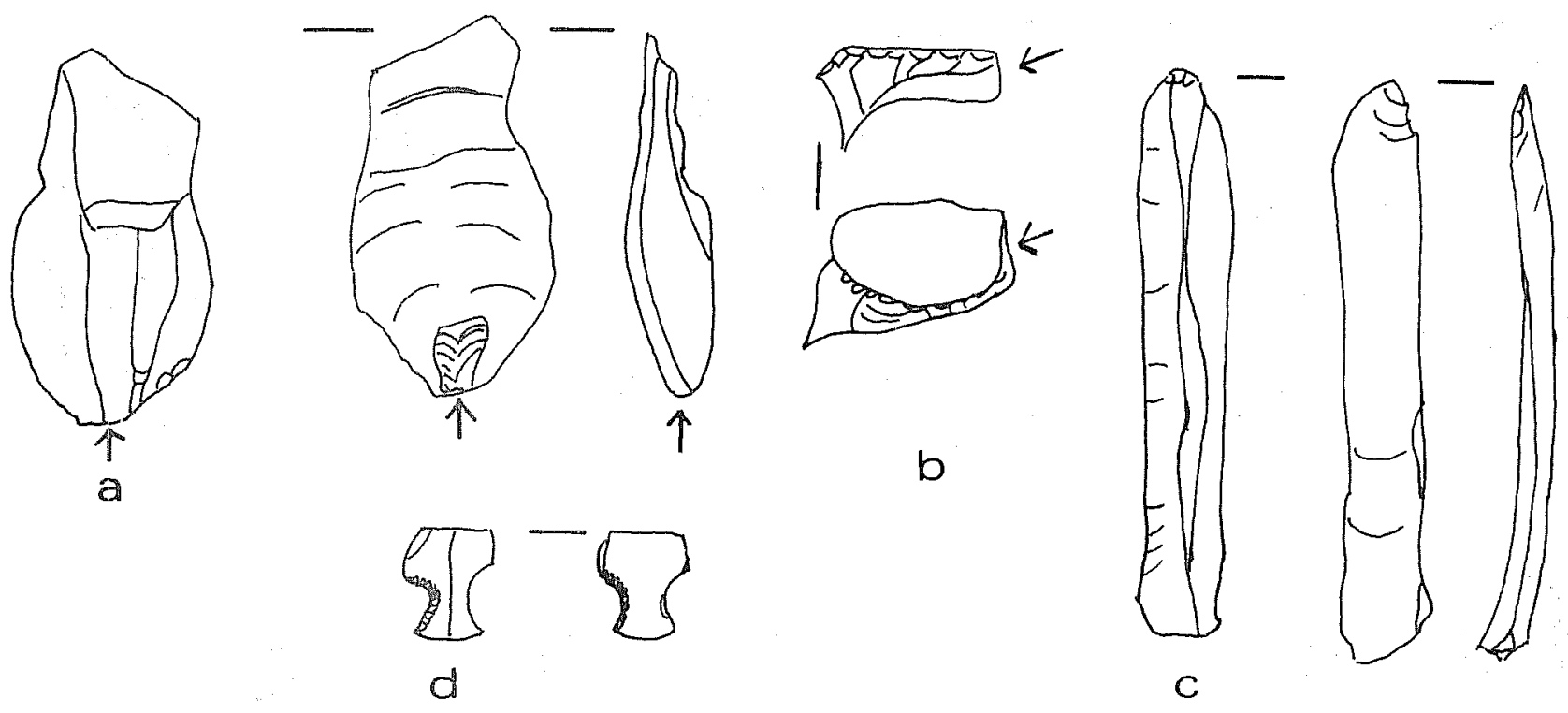

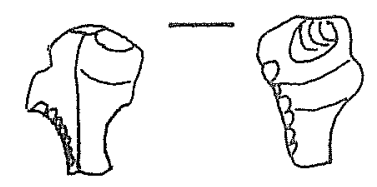

e

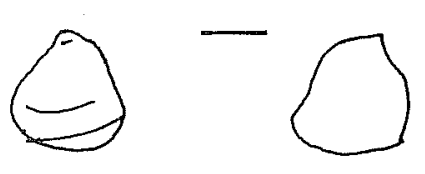

$f$
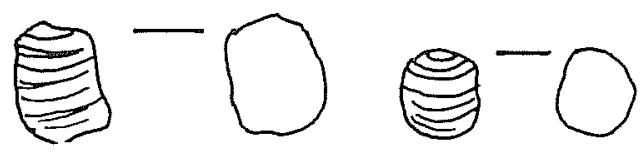

9 h

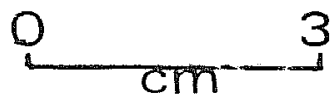

Fiqure 6. Obsidian debitage from El Pozito. a, Rejuvenation flake showing hinge fracture scar; b, core tablet; c, prismatic blade; d-e, strangulated blades; $f-h$, eraillure flakes. 
El Pozito. In this case the vessel was a large round-sided bowl with an eroded exterior design of geometric form. Another dish of the Late Classic is a shallow redware plate with slightly outflaring rim. In the unslipped ware, storage jars with outflaring rims and triangular bolsters were present. These compare to San Jose IV (Thompson 1939:126). Below the obsidian and the sascab floor, the sherds were mixed with examples from the Early and Late Classic and Late Preclassic Chicanel. Basal flanges and Early Classic polychromes were present.

\section{CONCLUSIONS}

These writers envisage an obsidian workshop set up for rather limited production of obsidian blades. This workshop is situated between two walls and features low stone stools the knappers could sit on (more or less in the position of a cow-milking stance). From this position it would have been easy to lean forward and apply pressure to a chest crutch. The soft sascab floor is thus covered with debris from this operation.

An obsidian workshop is indicated by the presence of manufactured blades, blade fragments, and core and platform rejuvenation and trimming flakes. Ceramic analysis indicates that the workshop activity occurred during the Late Classic Period. The presence of small eraillure flakes in nearly equal quantity (69 examples) to percussion flakes exhibiting eraillure flake scars (84 examples) is strong evidence that the debitage was produced in situ. Most of the debitage consists of discarded blades that were not acceptable as tools. There is even a shortage of expended cores. (In a tomb excavated during 1975 over 40 expended cores had been used as grave goods.) Therefore any valuable blades, tools or expended cores were distributed with the results that residue on the workshop floor were for the most part unusable or undesirable pieces. The absence of cortex fragments and "Targe blades" from the beginning stages indicates the cores were preformed elsewhere and blades were struck off with subsequent core rejuvenation and modification.

Crabtree (1968) describes a method for striking off prismatic blades. The description is taken from his own experiences with making blades and compared to the recorded 1 iterature at the time of the Spanish conquest. The knapper first places the preformed core within a vise which can be a simple A-frame of wood. The knapper then applies pressure with the chest crutch and the blades snap off the core. Although Crabtree finds a standing position more effective some of the accounts suggest that the knapper sits. Crabtree (1968:448) finds the sitting position impossible for himself but concedes that a seated position on a stone or immovable object would be advantageous. A look at Fig. 4 shows stones. in a very good position for sitting and striking off blades. A hard plaster floor would tend to dull the delicate edges of the blades as they fly from the core. Several of the stone objects are smoothed as if used for honing. These could have been used for sharpening the tip of the chest crutch which would have been replaceable. Various woods of Belize, such as lignum vitae (Guaiacum sanctum) and iron wood (Dialium guianense), are ideal as a crutch tip being some of the hardest woods known. The stone objects would also be used for scratching or grinding the platforms (Crabtree 1968: 
460).

The Targe number of specimens recovered from a two meter square test pit suggests a rapid accumulation of obsidian debitage from blade manufacture. It is conceivable that other such specialized activity areas exist within this same plazuela group or certainly within similar ones throughout the site environs. Careful analys is of these areas may shed more light on the larger questions of class or occupational stratification, population distribution, economic structure and trade affiliations.

\section{ACKNOWLEDGEMENTS}

We wish to thank Don Crabtree for his helpful comments and encouragement.

\section{REFERENCES CITED}

Adams, R. E. W.

1970 Suggested Classic Period Occupational Specialization in the Southern Maya Lowlands. In: Monographs and Papers in Maya Archaeology (ed. by W. R. BuTlard, Jr.):487-502. Papers of the Peabody Museum, Harvard University 61.

Becker, M.

1973 Archaeological Evidence for Occupational Specialization Among the Classic Period Maya at Tikal, Guatemala. American Antiquity 38:396-406.

Bullard, W. R.

1960 The Maya Settlement Pattern in Northeastern Peten, Guatema $1 a$. American Antiquity 25:355-372.

Crabtree, D. E.

1968. Mesoamerican Polyhedral Cores and Prismatic BTades. American Antiquity 33:446-478.

1972 An Introduction to Flintworking. Occasional Papers of the Idaho State University Museum 28.

Hammond, $\mathrm{N}$.

1973 British Museum-Cambridge University Corozal Project 1973 Interim Report. Centre of Latin American Studies, University of Cambridge, Cambridge.

1974 Preclassic to Postclassic in Northern Belize. Antiquity $48: 177-188$. 
Hester, T. R., R. N. Jack, and R. F. Heizer

1971 The Obsidian of Tres Zapotes, Veracruz, Mexico. Contributions of the University of California Archaeological Research Facility 13:65-131.

Mition, R.

1970 Teotihuacan: Completion of the Map. Science 170:1077-1082.

Munsell Soil Color Charts

1971 Kollmorgen Corporation. Baltimore, Maryland.

Siemens, A.

1974 The Rio Hondo Project: A Multidisciplinary Approach to Research on Human Ecology in Northern Belize. Paper presented at meetings of American Anthropological Association. Mexico City.

Thompson, J. E. S.

1939 Excavations at San Jose, British Honduras. Carnegie Institution of Washington, Publication 506. 
NOTES ON THE PRE-COLUMBIAN CHERT INDUSTRY OF NORTHERN BELIZE

\author{
John M. Andresen
}

\title{
INTRODUCTION
}

The 1974 UCLA survey of northern Belize produced a medium-sized collection of chert artifacts. This paper summarized the findings of the analys is and their implications for lowland Maya archaeology. The collection discussed here was obtained through excavations at 11 sites, most of them in the Corozal District of Belize (Fig. 1). The collection must be viewed in a regional framework. Intersite comparisons cannot be made because the sample from each site may not be fully representative. Fig. 2 gives the numerical breakdown of the collection by site. The bulk of the collection comes from the four sites of Aventura, Santa Rita, Chan Chen, and Patchchacan.

Each test pit at a site was numbered. Fig. 2 1ists the test pit numbers and sites. Within every test pit, each stratigraphic layer is numbered consecutively. For example, the first layer of test pit four is Ex. 4-1, and the sixth layer in test pit 23 is numbered Ex. 23-6.

\section{CLASSIFICATION AND TYPOLOGY}

Willey completed the first major analysis of a chipped stone collection from the Belize area as part of his survey of the Belize Valley (Willey et al. 1965). Later analyses of chipped stone artifacts from Belize have been sporadic and incomplete. The lack of consistency in lithic analys is for the Maya lowlands in general has been discussed by Sheets (1975a). The approach to classification and typology taken here is a result of the need for more systematic analysis.

Two decades ago, 0swalt (1955) based a classification of stone tools from Alaska on the technological procedures involved in their manufacture. Oswalt's approach received little acceptance at that time (cf. Oswalt 1973: 2). However, with in the past few years many lithic studies in the New World, particularly from Mesoamerica, have emphasized lithic technology and the manufacturing stages involved in stone tool production (Graham and Heizer 1968; Hester 1972, 1974; Sheets 1975b). The typology for the collection from northern Belize considers the technological stages of manufacture as well as the functions of the artifacts. The major divisions of the classification separate chert artifacts according to three stages of manufacture. The first major group includes the most crudely shaped tools produced by percussion techniques. These are such artifacts as flake cores, tool blanks, some debitage, and large blades. The term "large blade" is used here to mean large, parallel-sided flakes struck from a specially prepared core. These blades are triangular or trapezoidal in cross section and correspond to the obsidian macroblades described by Hester (1972) and large blades defined by Sheets (1975b:375). The core and blade technology of northern Belize is directly analogous to the coreblade technology well known at obsidian quarries in the Mesoamerican highlands. 


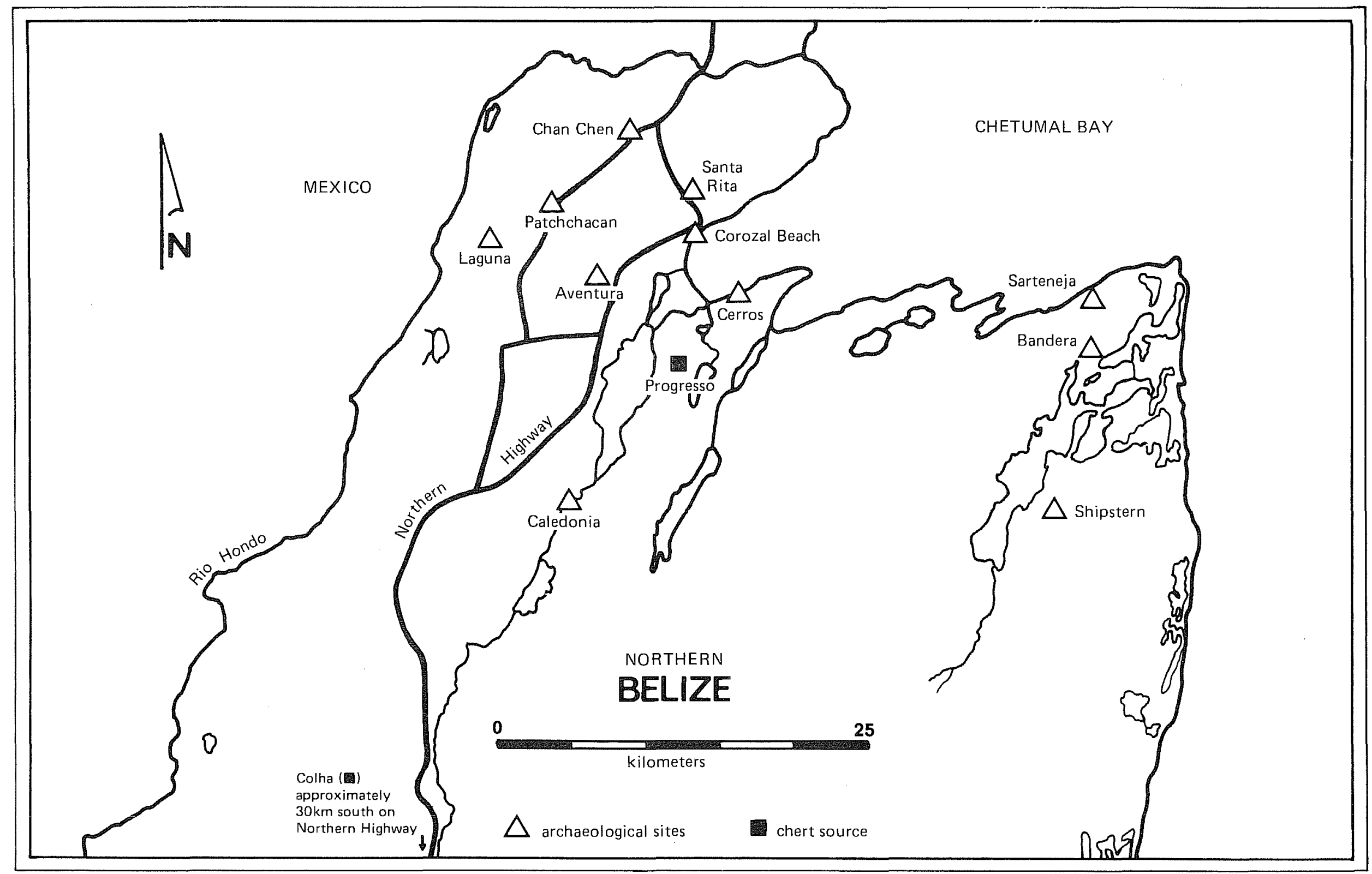

Figure 1. Map of northern Belize showing the locations of the eleven sites listed in Fig. 2. 


\begin{tabular}{|c|c|c|c|c|c|}
\hline$\underline{\text { SITE }}$ & COUNT & WEIGHT(KG.) & $\begin{array}{l}\text { PERCENT } \\
\text { BY COUNT }\end{array}$ & $\begin{array}{c}\text { PERCENT } \\
\text { BY WEIGHT } \\
\end{array}$ & $\begin{array}{l}\text { TEST PIT } \\
\text { NUMBERS } \\
\end{array}$ \\
\hline Aventura & 305 & 70.7 & 18.0 & 31.8 & 1 thru 8 \\
\hline Patchchacan & 169 & 2.9 & 9.9 & 8.7 & 9 thru 15 \\
\hline Caledonia & 304 & 9.1 & 17.9 & 27.2 & 16 thru 22 \\
\hline Chan Chen & 402 & 5.5 & 23.7 & 16.4 & 23 thru 33 \\
\hline Santa Rita & 399 & 2.9 & 23.5 & 8.7 & 34 thru 42 \\
\hline Shipstern & 10 & 0.2 & 0.6 & 0.5 & 43,44 \\
\hline Sarteneja & 91 & 1.5 & 5.4 & 4.4 & 45,46 \\
\hline Surface Collections* & 18 & 0.3 & 1.1 & 2.3 & --- \\
\hline TOTALS & 1,698 & 33.5 & $100.1^{* *}$ & 100.0 & \\
\hline
\end{tabular}

* Four sites yielded chert artifacts through surface collections: Bandera, Cerros Beach, Corozal Beach, and Laguna.

** All decimals were rounded to nearest tenth unit before inclusion in table. Inconsistencies are due to rounding.

Figure 2. Distribution of collection by site, with listing of test pit numbering sequence. 
1) PRIMARY CATEGORY ARTIFACTS

Associated technological procedures: Core reduction and percussion detachment of Macroblades, production of large flakes and Tool Blanks.
A. Flake Cores
B. Tool Blanks and Large Blades
C. Hammerstones
D. Large Flakes to be reduced further
E. Residual Waste

2) SECONDARY CATEGORY ARTIFACTS Associated technological procedures: continued reduction of cores and flakes by direct and indirect percussion, completion of crude tools.
A. Unifacial Scrapers
B. Crude, Unifacial Knives
C. Crude, Bifacial Scrapers and Knives
D. Partially Worked Too 1 Blanks

3) FINELY FINISHED ARTIFACTS Associated technological procedures: final thinning of bifaces by pressure flaking, production of pressure-made waste flakes.
A. Dri17s, Gougers
B. Arrow Points
C. Fine, Bifacial Scrapers
D. Fine, Bifacial Knives or Points
E. Choppers and Pick-like Tools
F. Large, Stemmed Points
G. Ceremonial Implements
H. Burin Spalls and Prismatic Blades
J. Pressure Waste Flakes 


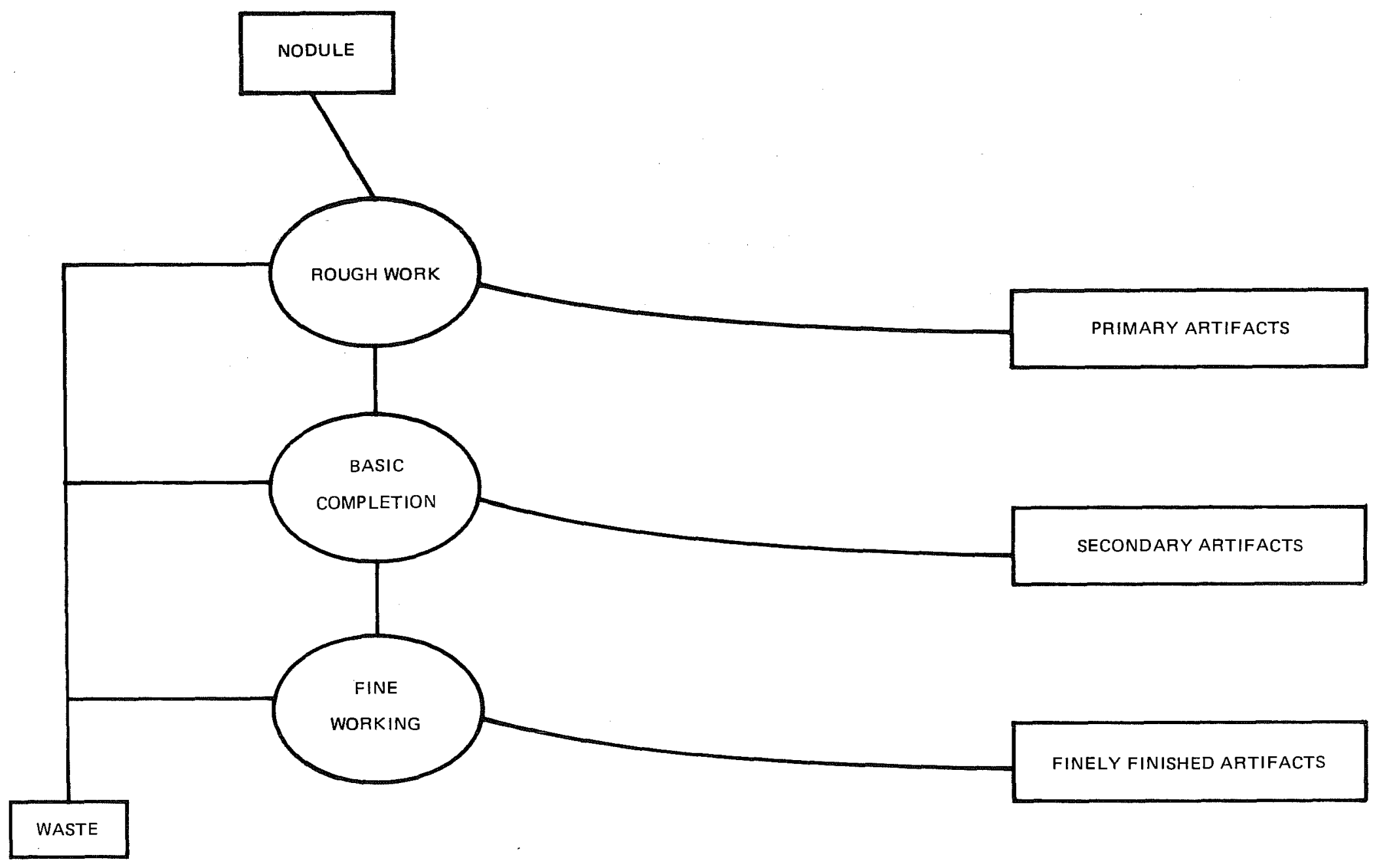

Figure 4. Diagram showing the relationships between three major stages of chert tool manufacture and their products. 
The second manufacturing category consists of flakes, tool blanks, and cores that have been further worked into crude knives or scrapers, and multi-purpose tools. They may be unifacial or bifacial and are characterized by the deep scars of percussion flaking. Tools in this category may be used, or they may be further worked in the third stage.

The last manufacturing category includes artifacts that have been carefully worked and finished by delicate pressure flaking. Prismatic blades, smal1 arrow points, and ceremonial implements are examples of artifacts in this group.

The subdivisions within the technological categories are based on tool functions. Morphology, macroscopic traces of wear, and comparisons with other chert analyses aided in the functional assignments. However, no functional classification can be conclusively established since it is possible that a given tool had several uses. The 1700 chert specimens in the collection have been separated into 20 artifact types by this procedure. The lack of quarry and workshop data prevents a more detailed framework for analysis.

Epstein (1964:163) points out that tool manufacture relates to tool status. The analytic procedure outlined above makes a correlation between lithic manufacturing effort and the status of the finished item. This correlation applies to the Maya chert industry and should not be extended to other lithic industries. This model reflects the fact that hastily made cutting implements were low status tools, while carefully manufactured ceremonial blades and eccentrics were used for high status purposes.

\section{THE COLLECTION}

The collection was initially analyzed in the fall of 1974 (Andresen 1974). Nearly 1700 chert specimens $(33.5 \mathrm{~kg})$ were classified. Most of these are classified in non-tool groupings: flake cores, debitage, tool blanks, waste flakes and chunks, and unidentifiable fragments. These "marginal" types make up three-fourths of the collection, $67 \%$ by weight and $85 \%$ by count. A few of the types are represented by only one or two complete specimens (Fig. 5). The collection is permanently stored with the Department of Anthropology, University of Illinois, Urbana.

Twenty artifact types are described below. Within the descriptions of individual types, particular specimens are discussed. The dimensions of particular specimens are presented in a standardized format for descriptive efficiency. Dimensions are recorded in centimeters and enclosed in parenthesis, e.g. $(10 \times 5 \times 1.5)$ represents length, width, and thickness in that order.

\section{Flake Cores}

Flake cores represent $3 \%$ of the collection by count and nearly one-third of the collection by weight. Forty-five flake cores are recorded; mean weight is $243 \mathrm{gm}$. These cores range in maximum dimensions from $4.5 \mathrm{~cm}$ to about $21 \mathrm{~cm}$. Twenty-four show light to heavy battering while the rest show no macroscopic signs of secondary use. Both small and large cores 
TYPE

Flake cores

Tool blanks

Residual waste

Hammers tones

Large blades

Unifacial scrapers

Unifacial knives

Crude, bifacial scrapers

Crude, bifacial knives

Fine, bifacial scrapers

Fine, bifacial knives or points

Dril1s, gougers

Choppers, axes

Pick-1ike tools

Arrow points

Knife or scraper fragments*

Large, stemmed points

Prismatic blades

Burin spalls

Ceremonial implements

Pressure-made waste flakes

TOTALS

* Not a "type".

COUNT WEIGHT $(\mathrm{gm})$ COMPLETE INCOMPLETE

$\begin{array}{rr}45 & 10,931 \\ 1 & 206 \\ 703 & 9,741 \\ 7 & 418 \\ 4 & 500 \\ 5 & 336 \\ 2 & 140 \\ 29 & 1,692 \\ 11 & 476 \\ 24 & 1,732 \\ 84 & 3,161 \\ 12 & 238 \\ 2 & 483 \\ 2 & 386 \\ 10 & 12 \\ 19 & 566 \\ 2 & 104 \\ 24 & 189 \\ 2 & 3 \\ 12 & 529 \\ 698 & 1,699 \\ 1,698 & 33,544\end{array}$

-
1
2
1
4
1
6
0
5
3
8
1
1
6
-
1
12
2
4
-

$\overline{0}$

$-$

5

3

1

1

11

19

81

4

1

1
4

$\overline{1}$

12

0

8

58

175

Figure 5. Distribution of collection by type. 
display battering. No cores had been specialiy prepared for the removal of chert prismatic blades.

Too 1 BTanks and Large BTades

An initial step in chert tool manufacture is the production of tool blanks. These are flakes that are suitable for working into a variety of tools. Some tool blanks can be put to use without further modification. Most of the tool blanks in the collection were manufactured by the blade-making process described by Bordes and Crabtree (1969:10). These special7y detached tool blanks are classified as large blades.

The large blades in the collection (Fig. 6 b, d) resemble the "Prismatic Flake B1ade, Large" described by Wi17ey et al. (1965:441, Fig. 278d). A7though only one of the large blades in the present collection is complete, a11 four are trapezoidal in cross section and were detached from a specialiy prepared core. In these respects they are analogous to the obsidian tool blanks from El Chayal described by Coe (1966:39, Fig. 4). One Targe blade $(10.5 \times 5.5 \times 2.0)$ was recovered from Ex. 27-7. One edge retains the cortex and the other edge tapers to a thin blade that shows considerable use-nicking (Fig. 6 b). The two lateral edges are nearly para17el.

Another example (Fig. 6 d), also from Ex. 27-1, was detached from a specialiy prepared core. The medial flake scar, the nearly parallel sides, the trapezoidal cross section, and the small point of contact on the striking platform indicate that this specimen is a chert counterpart to the large obsidian blades found at obsidian quarries throughout the Mesoamerican hightands.

One tool blank does not result from the blade-making process. The artifact (Fig. 6 a) is from Ex. 9-1 and is rectangular in out7 ine $(11.0 \times 6.5 \times 2.8$; $206 \mathrm{gm})$. One edge is thin, sharp and shows use in the form of tiny crushed spots. The rest of the specimen appears unaltered by use. This artifact represents one aspect of the initial stage of manufacture diagrammed in Fig. 4.

The production and transport of obsidian tool blanks and the utilization of unmodified tool blanks are described by Graham and Heizer (1968), Sheets (1975b), and Hester (1972, 1974). The artifacts classified as too 1 blanks or large blades in this collection suggest that chert technology in northern Belize involved analogous practices and manufacturing techniques.

\section{Hammers tones}

Percussion instruments are, of course, essential to any percussion approach to chertworking. Accordingly, the two complete and three incomplete hammerstones in the collection are classified as Primary Category Artifacts (see Fig. 3). These are waste chunks or nearly exhausted flake cores that were used to detach flakes from other specimens by percussion. The hammerstones show battering over a 11 surfaces. 


\section{Unifacial Knives}

Unifacial knives are large, unifacially modified flakes that bear at least one edge suitable for general cutting purposes. These artifacts were worked by direct, and possibly indirect, percussion techniques. Their surfaces exhibit large conchoidal flake scars; cross sections and irregular. A complete unifacial knife (Fig. 9 a) was recovered from the surface collection at Cerros Beach. One incomplete specimen is recorded from Ex. 20-B. These artifacts are in the second major manufacturing category (Fig. 3) and are considered finished artifacts. However, uni-

facial knives are morphologically general enough to serve as preforms for other tools. It is difficult to distinguish a discarded, slightly worked preform from a finished but unused Secondary Category artifact. Wilk has encountered the same problem in analyzing the chipped stone industry at Colha, Belize (Hammond 1973:59). Accordingly, the Secondary Category combines finished and unfinished artifacts.

Unifacial Scrapers

A unifacial scraper $(8.0 \times 3.0 \times 1.7)$ obtained from Cerros Beach was manufactured from a large blade. The artifact (Fig. 7 a) is rectangular in outline, trapezoidal in transverse cross section, and slightly curved on the longitudinal axis. This specimen closely resembles the "Prismatic End- and Side-Scrapers" from Barton Ramie (Wi1ley et al. 1965:437 and Fig. 274 h-k).

One incomplete and three complete unifacial scrapers are roughly circular in outline and bear deep flake scars (Fig. 7 b). These compare with one illustrated from Altar de Sacrificios (Willey 1972: Fig. 157 e) and another from Barton Ramie (Willey et al. 1965: Fig. 227 b). The unifacial scrapers in the present collection range in diameter from 4.7 to $5.2 \mathrm{~cm}$ and in thickness from 2.0 to $3.5 \mathrm{~cm}$.

Crude, Bifacial Knives

Crude, bifacial knives are the bifacial counterparts to unifacial knives described above. They are crudely manufactured and display large, deep flake scars on all surfaces. Eleven incomplete and nearly complete specimens are classified as crude, bifacial knives.

Proskouriakoff (1962:362) describes several "Asymmetrical Flints" that are equivalent to the crude, bifacial knives from northern Belize. Willey (1972:174) notes several "coarsely chipped Bi-pointed Knives" from Altar de Sacrificios that he describes as suitable for gouging or cutting. They are equivalent to the crude, bifacial knives in this collection. These artifacts were intended for the roughest tasks and were probably easily discarded. Some may have been intended for further reduction.

Crude, Bifacial Scrapers

Crude, bifacial scrapers exhibit crude, deep flaking and are suited to scraping functions though they may have also served some rough cutting functions. Outlines range from oval to circular and cross sections 
Figure 6. Tool Blank and Macroblades. a, Tool Blank from Ex. 9-1 (Patchchacan); b, Macroblade from Ex. 27-1 (Str. F-2, Chan Chen); c, Large, Stemmed Point made from a Macroblade, stem is bifacially worked, from Ex. 27-1 (Chan Chen); d, Macroblade from Ex. 27-1. 

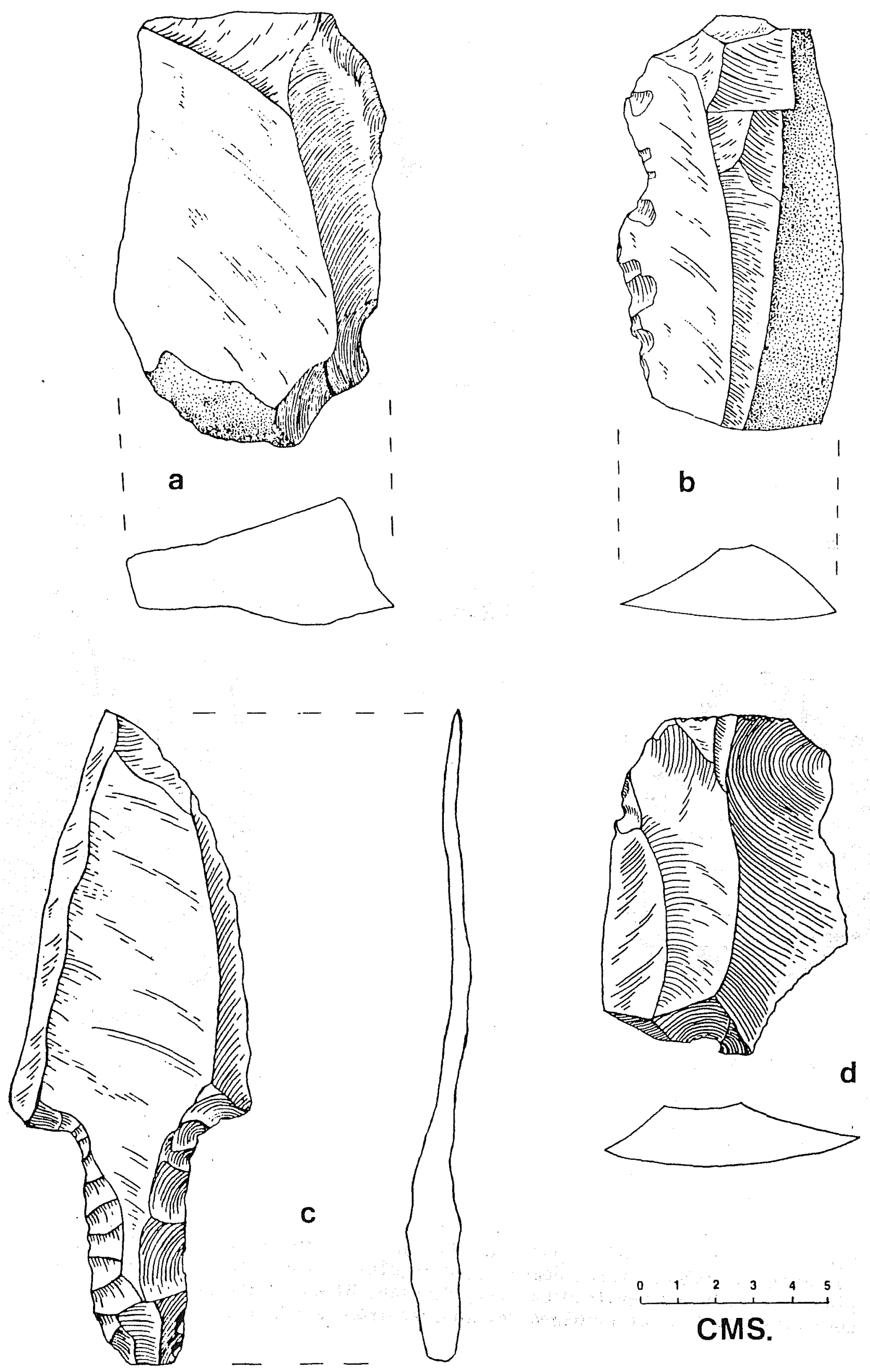

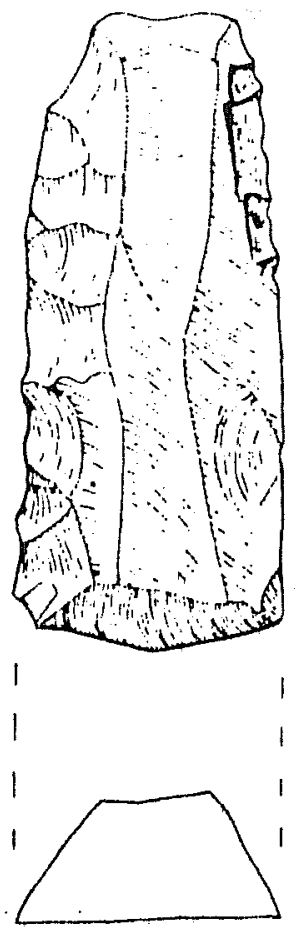

a
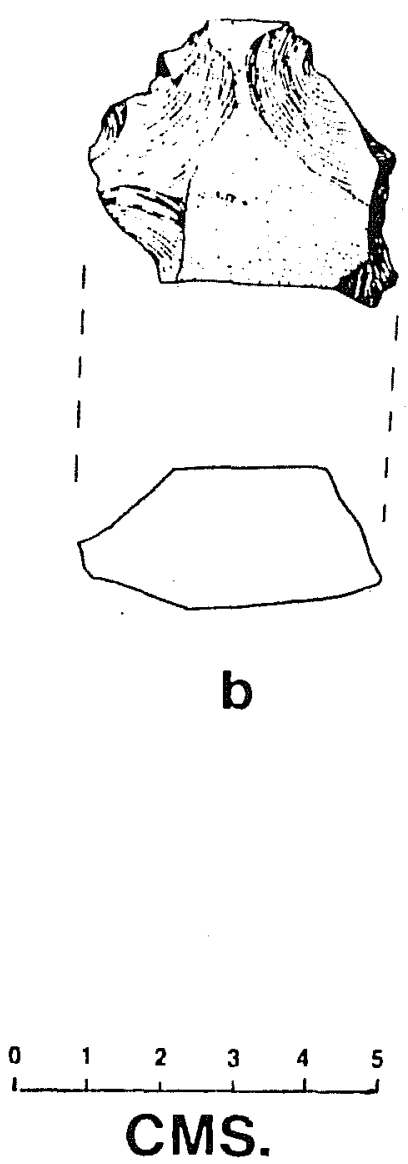
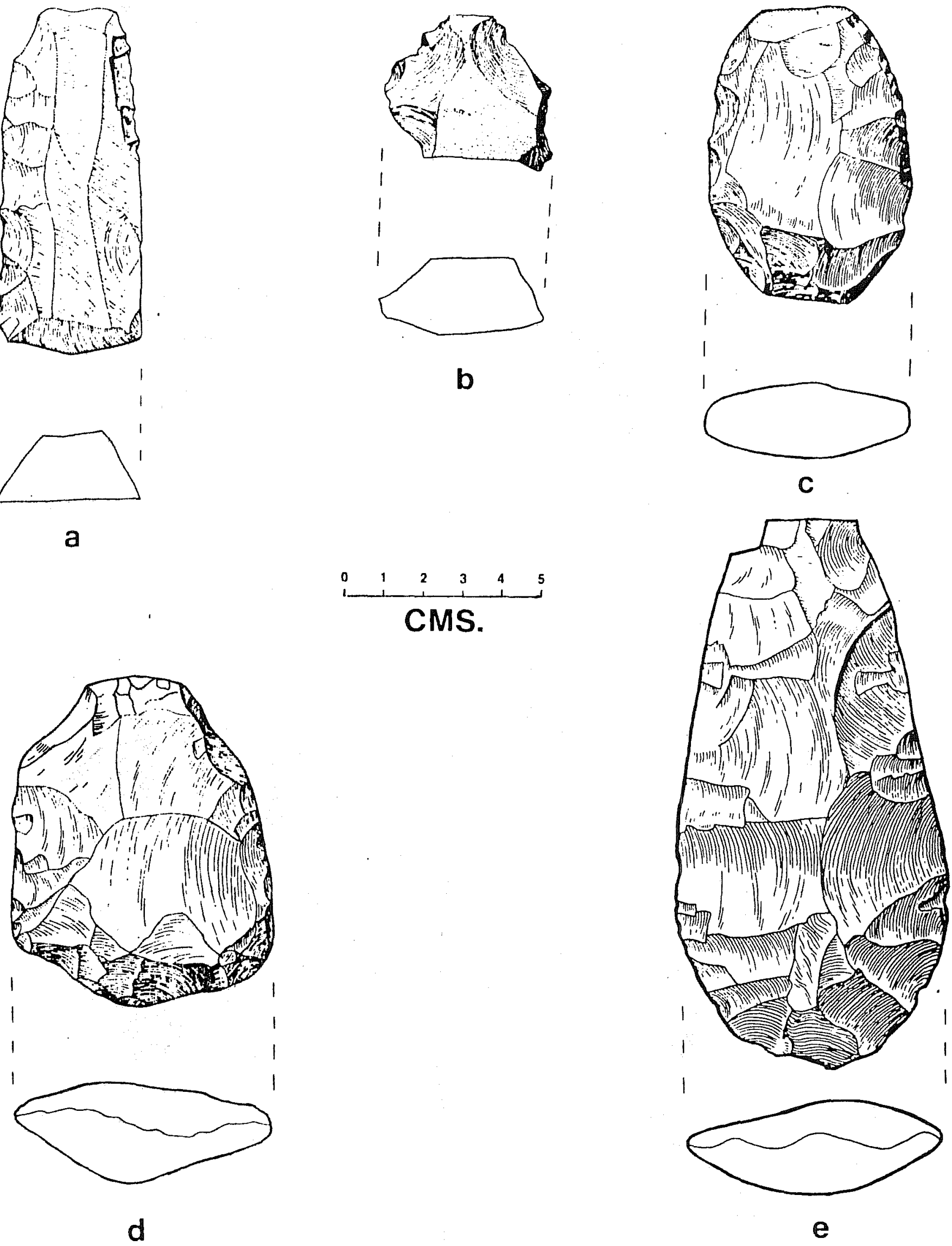

Figure 7. Scrapers and Chopper. a, Unifacial Scraper made from a Macroblade; surface collection, Cerros Beach; b, Unifacial Scraper, Ex. 1-1 (Aventura); c, Fine, Bifacial Scraper from Ex. 1-1; d, Fine, Bifacial Scraper from CM-S, a surface collection at Aventura; e, Chopper from Ex. 27-1 (Str. F-2, Chan Chen). 
approach ellipses. There are six complete and 23 fragmentary artifacts recorded for this type. These range from 4.5 to $6.0 \mathrm{~cm}$ in diameter or length, with thicknesses between 1.7 and $2.8 \mathrm{~cm}$. None of these specimens show evidence of final reduction, or "thinning", by pressure flaking.

Dri11s

Drills in this collection are essentially chips or thick flakes that have been modified by the removal of tiny flakes to form a sharp point suitable for boring, drilling, or gouging. A total of eight complete and four incomplete drills was recovered (Fig. $8 \mathrm{~g}, \mathrm{~h}$ ).

Fine, Bifacial Scrapers

Fine, bifacial scrapers are elliptical in transverse cross section and in outline and have been thinned by pressure flaking (Fig. 7 c, d). Shallow flake scars on both faces are characteristic of this tool type. These artifacts correspond in function and description to the "Scrapers: Bifacial, Fine" from Altar de Sacrificios (Willey 1972:177). They are quite similar to some of the smaller examples of the "Hatchet-Form Flints" from Mayapan (Proskouriakoff 1962: Fig. 31 p-s). Five complete and 19 incomplete fine, bifacial scrapers range in length from 6.9 to $8.0 \mathrm{~cm}$. Widths are 5.0 to $6.5 \mathrm{~cm}$ and thicknesses 2.0 to $3.0 \mathrm{~cm}$. All of the scrapers in this group show light to medium wear along the lateral edges. Most are from Late Classic deposits.

Arrow Points

Proskouriakoff (1962:360) establishes that these tiny, distinctive arrow points (Fig. 8) were introduced into northern Yucatan in "very late times". The arrow points described below come from definite Postclassic contexts. Arrow points are the most delicately pressure flaked tools in this collection. Like the arrow points from Mayapan, not one of these exceeds three gm. Six complete and nearly complete arrow points and four incomplete specimens were recovered.

Following Proskouriakoff (1962:360), two arrow points are classified as Side-Notched, Straight Base. One of these $(3.9 \times 1.4 \times 0.3$; Fig. 8 d) is from Ex. 5-S. The other $(4.2 \times 1.2 \times 0.3$; Fig. $8 \mathrm{~d})$ is from Corozal Beach. Two specimens are classified as Side-Notched, Round Base arrow points. One is complete $(3.0 \times 1.2 \times 0.2$; Fig. $8 \mathrm{f})$ and was recovered from Ex. 37-2. The other $(3.0 \times 1.6 \times 0.4$; Fig. 8 e) is nearly complete and was recovered from Ex. 40-S. Four nearly complete arrow points are Side-Notched with an undetermined base form (Fig. 8 a, c). Most of the arrow points in the collection were made from prismatic blades; all have been bifacially modified. This modification is minimal on some specimens.

Fine, Bifacial Knives or Points

Three complete and 81 incomplete artifacts are classified as bifacial knives or points. Because this study lacks thorough use-wear examinations it is difficult to separate projectile points from bifacial knives. In some cases the distinction can be made on the basis of morphology. One complete fine, bifacial knife $(7.5 \times 4.7 \times 2.1)$ from Ex.9-1 is rectan- 


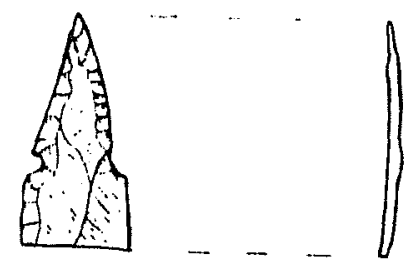

a
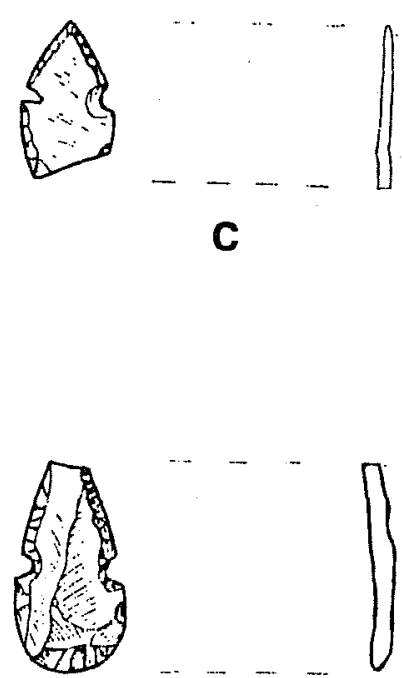

e
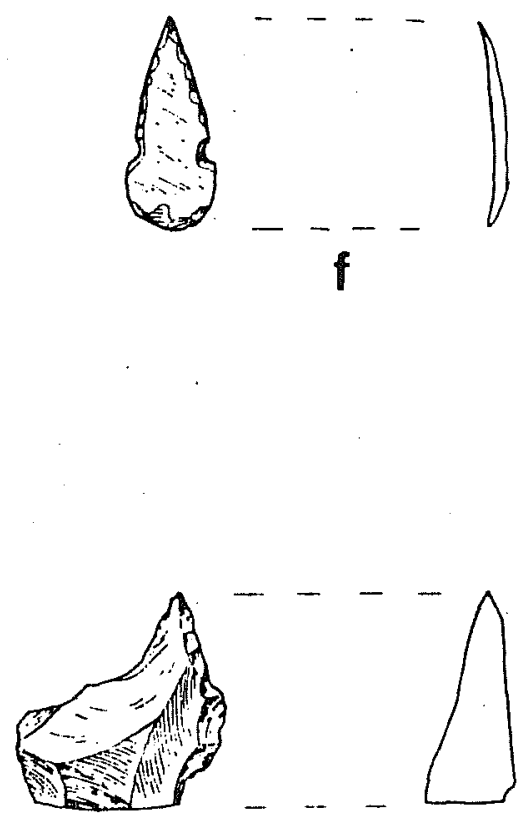

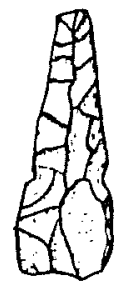

b
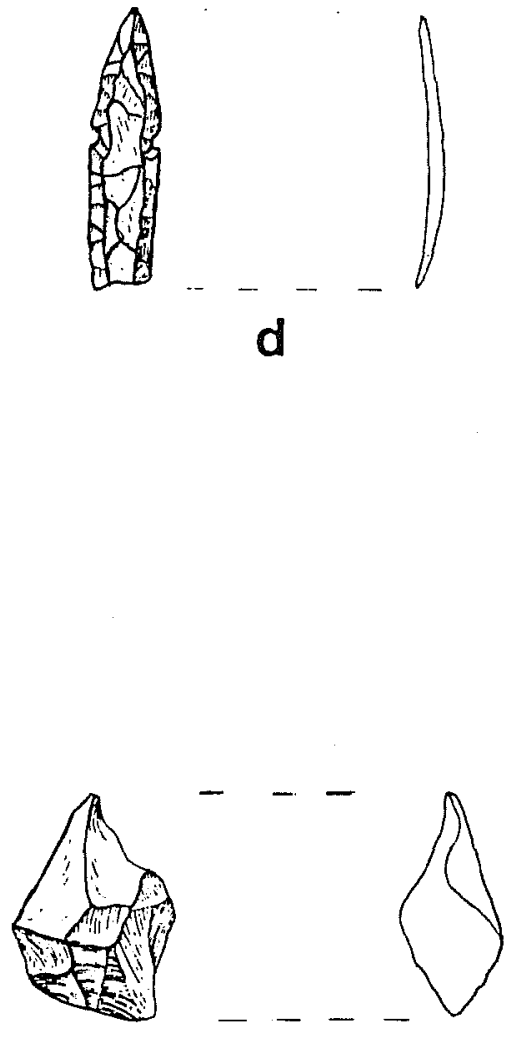

g h

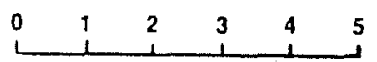

CMS.

Figure 8. Arrow Points and Drills. a, Nearly complete Side-Notched Arrow Point, base from undetermined, Ex. 37-2 (Santa Rita); b, SideNotched, Straight Base Arrow Point, surface col-
de-Notched Arrow Point, base form undetermined, ection, Corozal Beach; c, Nearly complete Side-Notched Arrow Point, base form undetermined
x. 37-2; d, Side-Notched, Straight Base Arrow Point, Ex. 5-S; e, Side-Notched, Round Base rrow Point, 40-S (Santa Rita); f, Side-Notched, Round Base Arrow Point, Ex. 37-2; g, Dril1 rom surface collection, Ex. 23 (Chan Chen); h, Dri11, Ex. 46 (Sarteneja). 

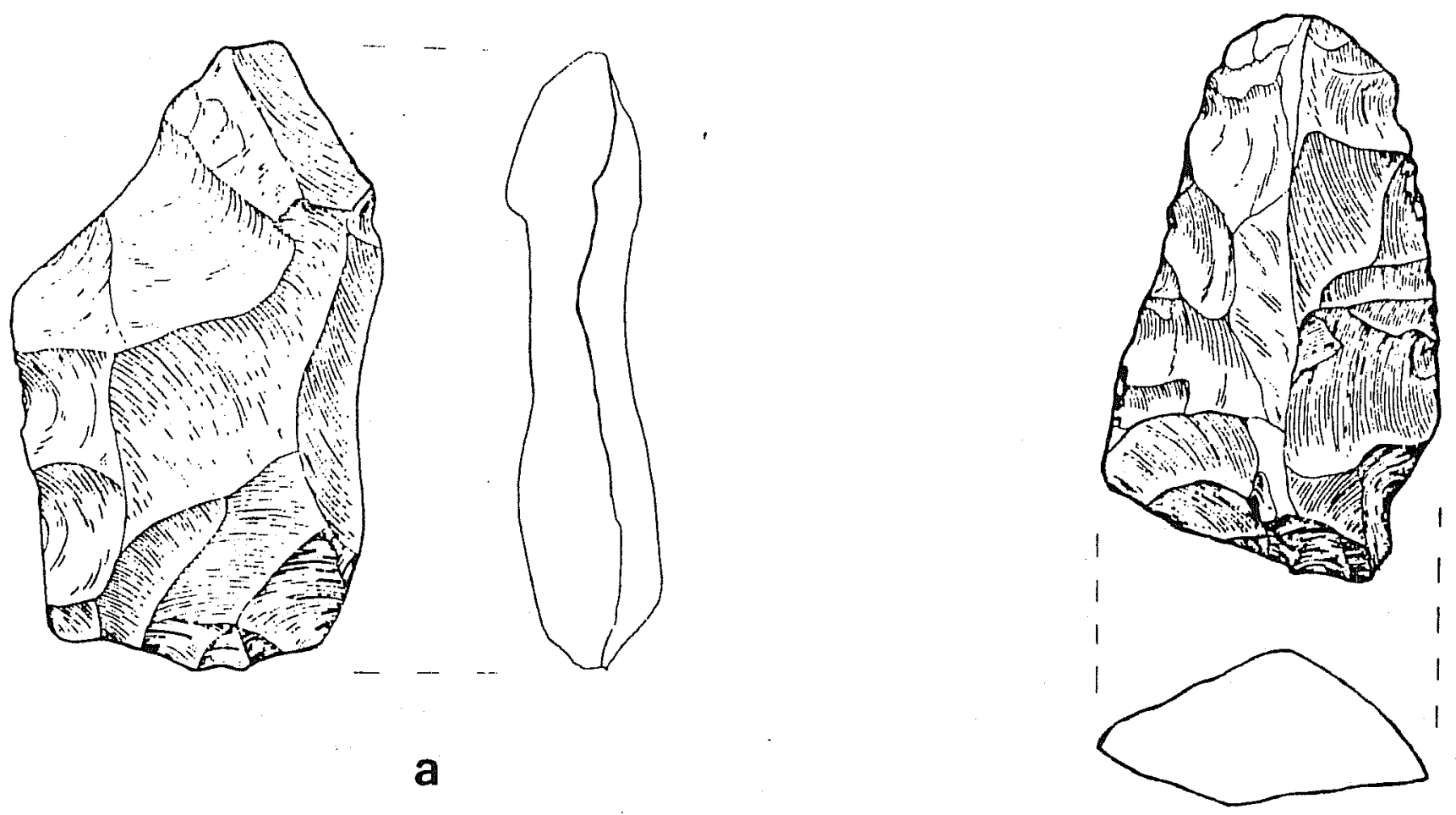

b
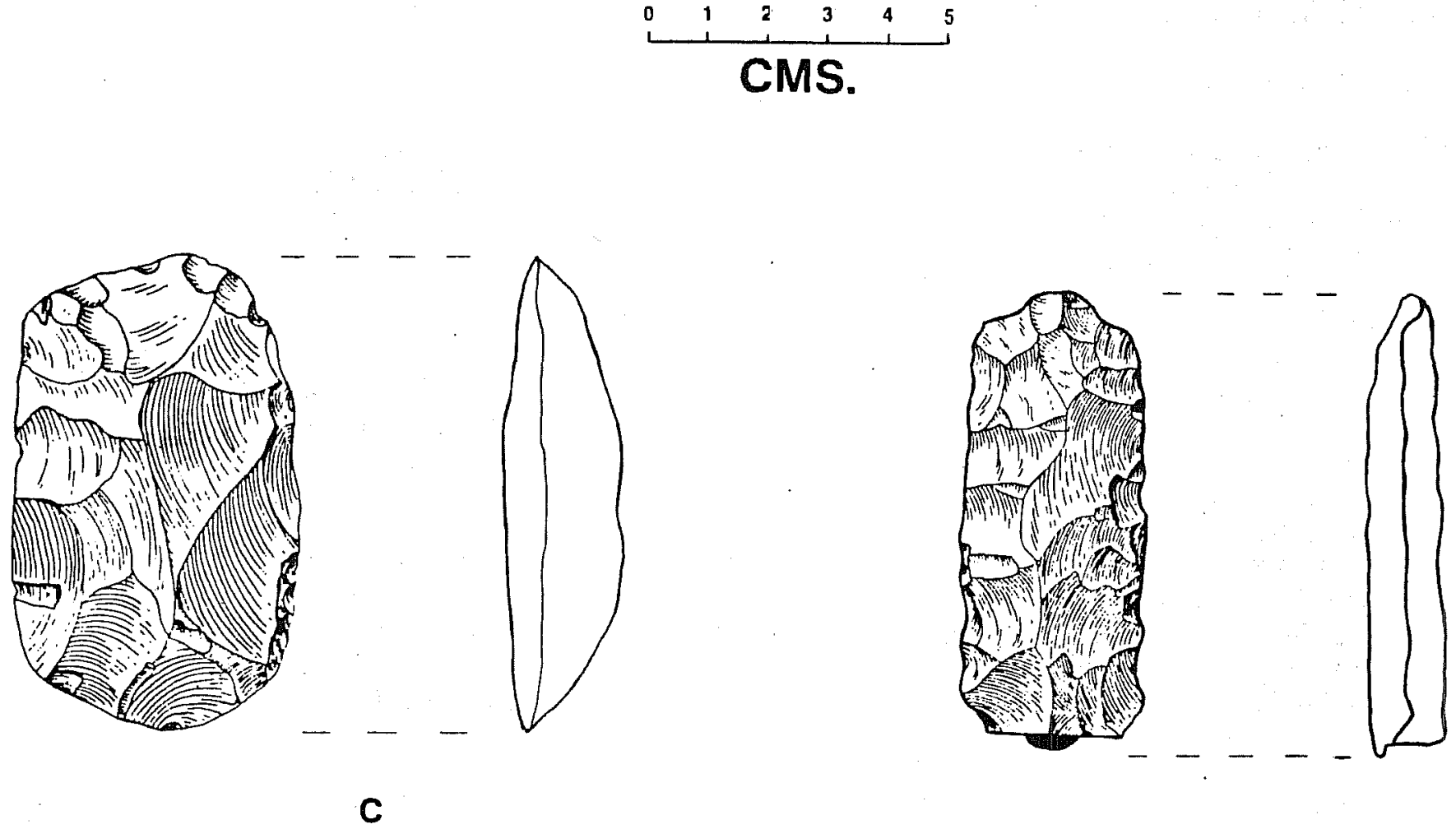

Figure 9. Knives. a, Unifacial Knife from the Cerros Beach surface collection; b, Fine, Bifacial Knife fragment with rounded tip, Ex. 1-1; c, Fine, Bifacial Knife from Ex. 9-1 (Patchchacan); d, This Fine, Bifacial Knife fragment was recovered from Ex. 46 (Sarteneja). 
gular in outline with two evenly chipped, sharp lateral edges. Cross section is plano-convex (Fig. $9 \mathrm{c}$ ). The slight polish on both faces of the butt end suggests this tool may have been hafted. However, it is suitable for hafted or hand-held use and the macroscopic traces of wear along all edges suggest it may have been used in a variety of positions.

Two incomplete artifacts classified as fine, bifacial knives or points were most likely used as knives (Fig. 9 b, d).

An incomplete artifact from Ex. 32-1 (Fig. 10 a) consists of the lower half of a stemmed projectile point. It measures $3.0 \mathrm{~cm}$ in width and 0.5 $\mathrm{cm}$ in thickness. This artifact resembles stemmed points reported from Barton Ramie (Willey et al. 1965:412, Fig. 261) and resembles more closely the points classified as "Straight Stem, Long Blade" from Altar de Sacrificios (Willey 1972:162). Two nearly complete projectile points are unstemmed and show fine bifacial working. Both are nearly $8 \mathrm{~cm}$ in length, $3 \mathrm{~cm}$ in thickness and 1.0 to $1.5 \mathrm{~cm}$ in thickness. They are identical to each other in style and proportions. One is from Ex. 9-1, the other from Ex. 27-3 (Fig. 10 b). The latter dates to the Late Preclassic Period.

The remaining specimens classified as knives or points are either cutting or piercing implements. These tools were all finished with a degree of pressure flaking, though a continuum in chipping quality is displayed. Cross sections range from triangular to elliptical with either converging or parallel lateral edges. Tips are rounded in most cases.

Knife or Scraper Fragments

Nineteen fragments are classified as either knives or scrapers. These were so badly fragmented that more precise identification is impossible. Most are bifacially worked and bear evidence of pressure flaking. Some may be Secondary Category artifacts.

\section{Choppers or Axes}

Heavy chopping tools must have played an important role in lowland Maya life. Agricultural land was cleared regularly and ancient Mayan workers needed chopping and cutting tools for the task. It is surprising that the 1974 UCLA survey found so few chopping and heavy cutting tools in northern Belize. Two artifacts, one whole and one fragmentary, are classified as choppers. These implements correspond to the "Chopping tools, standard form" from Uaxactun (Kidder 1947: Fig. 61), to the "Standard Choppers, Bifacial" from Barton Ramie (Wi17ey et al. 1965:423), and to the "General Utility Form Choppers" from Altar de Sacrificios (Willey 1972:157). They resemble less closely the chopper from Mayapan (Proskouriakoff 1962: Fig. 32 v).

The whole chopper $(13.5 \times 6.4 \times 2.6)$ in the collection was recovered from Ex. 27-1. Large shallow flake scars (Fig. 7 e) cover both faces, with no macroscopic evidence of use along the edges. The incomplete chopper is from Ex. 9-1, and is the same with respect to workmanship as the whole chopper. Ful1 length is indeterminate. The lateral edges are crushed from use. 


\section{Large, Stemmed Points}

Large, stemmed points are bifacially modified large blades. They are technologically identical to the large obsidian and chert "Lance Points" from Chiapa de Corzo (Lee 1969:154) and the three "Points or Knives: Stemmed, Plano-Convex" from Barton Ramie (Wi1ley et al. 1965:412, 417). The complete specimen $(17.4 \times 6.5 \times 1.5)$ is lenticular in transverse cross section at the proximal end, or stem. The blade is trapezoidal in transverse cross section and averages $0.4 \mathrm{~cm}$ in thickness (Fig. $6 \mathrm{c}$ ). The tip fragment of a large, stemmed point was recovered during a surface collection at Cerros Beach. It is triangular in cross section and displays slight bifacial retouch at the extreme tip. Willey notes fine retouch at the top of one of the three large, stemmed points in the Barton Ramie collection (Willey et al. 1965:412).

Pick-like Tools

One nearly complete pick-like tool $(17.0 \times 5.3 \times 2.3)$ with a small bit of the tip broken was found in Ex. 15-1. This long, slender tool was carefully pressure-flaked over parts of both faces (Fig. 11 a). One incomplete specimen from $20-B$ is also classified as a pick-like tool. It is the midsection of a large, bifacially pressure-flaked tool. The specific function of pick-like tools is unknown.

\section{Ceremonial Implements}

The high quality of chipping on ceremonial implements corresponds to the high status the artifacts had in ancient Maya society. The ceremonial implements are the most evenly chipped and most consistently pressureflaked artifacts in the collection. One incomplete and four complete specimens were recovered in ritual contexts. Seven incomplete ceremonial implements were found in refuse deposits and fill.

One incomplete and three complete ceremonial implements were found with the stela in Group B, Chan Chen (Ex. 33-1). One of the complete examples $(9.5 \times 2.8 \times 0.9)$ is bipointed with a triangular tip. An incomplete "ritual flint" from Mayapan has an identical tip and is classified as an eccentric (Proskouriakoff 1962: Fig. $27 \mathrm{j}$ ). The other two complete ceremonial implements from Ex. 33-1 are triangular in outline. One of these $(9.2 \times 5.5 \times 1.0)$ is illustrated in Fig. $11 \mathrm{c}$. The other measures 8.0 by 5.3 by $1.1 \mathrm{~cm}$; both are made of fine grained brown chert. The incomplete ceremonial implement from Ex. 33-1 (Fig. 11 b) is a laurel leaf blade with one tip missing. This specimen measures $4.8 \mathrm{~cm}$ in width and $0.7 \mathrm{~cm}$ in thickness.

One complete laurel leaf blade (Fig. 11 d) was recovered during the excavation of Ex. 10-1, a Postclassic ceremonial deposit at Patchchacan (11.7 $\mathrm{x}$ $3.6 \times 1.2)$.

Prismatic Blades

Chert prismatic blades correspond in method of production to the familiar obsidian prismatic blades common at archaeological sites throughout Mesoamerica. These artifacts are the result of a specialized pressure method 


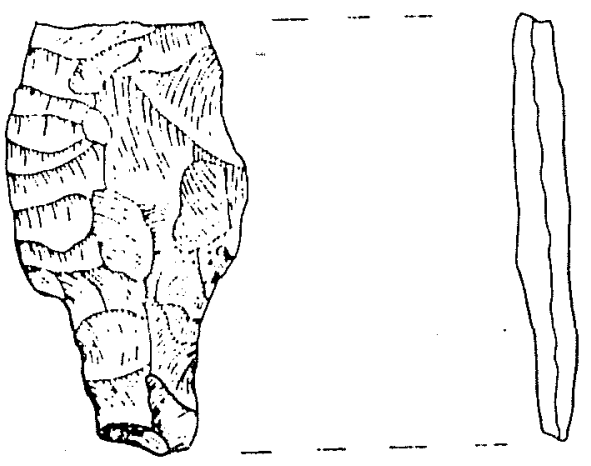

a

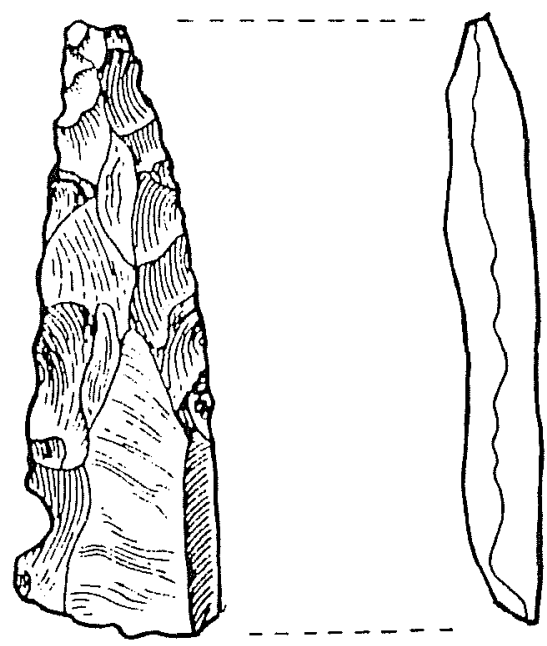

b
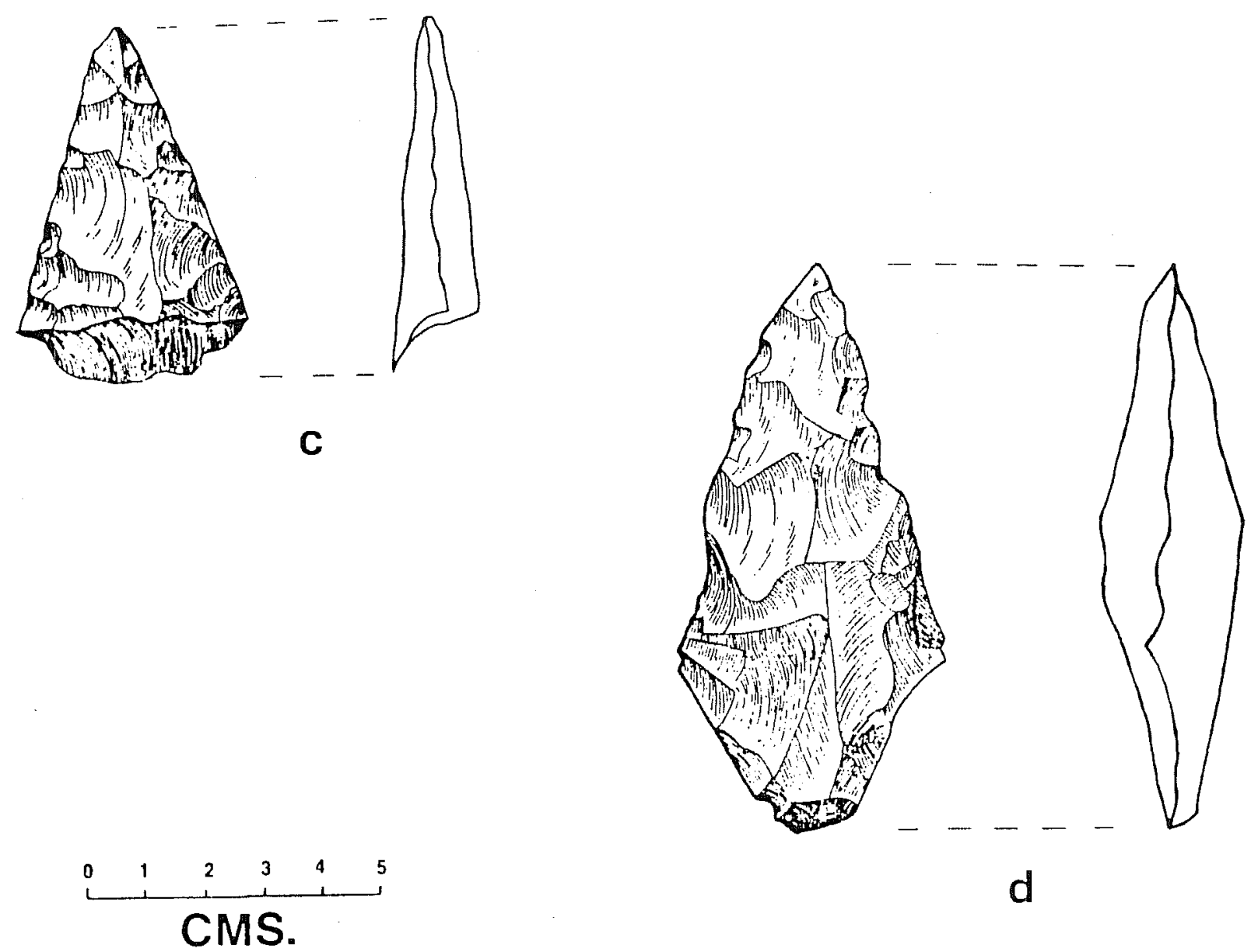

Figure 10. Fine, bifacial knives or points. a, Base of a Stemmed Projectile Point, Ex. 32-1 (Str. A-1, Chan Chen); b, Nearly complete Projectile Point from Ex. 27-3 (Str. 5-2, Chan Chen); c, Fragment of a Knife or Point, Ex. 20-B (Str. A-1, Caledonia); d, Complete Knife or Point from the Ex. 13 surface collection (Patchchacan). 

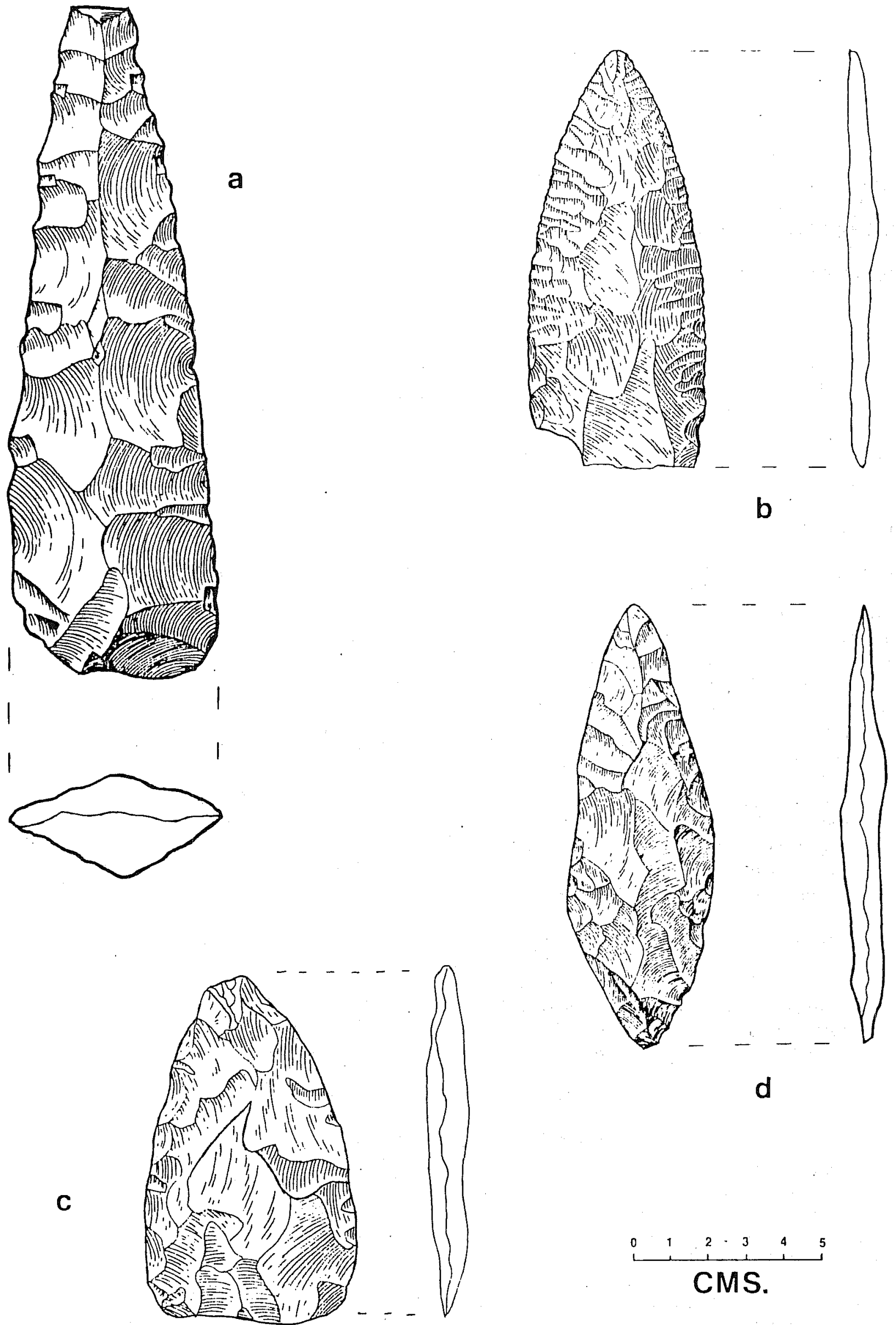

CMS.

Figure 11. Pick-like tool and ceremonial implements. a, Pick-1ike Tool, Ex. 15-1 (Patchchacan) b, Ceremonial laurel leaf blade, Ex. 33-1 (Chan Chen); c, Complete triangular Ceremonial Implement from Ex. 33-1; d, Ceremonial Implement from 10-1, Late Postclassic ritual deposit (Patchchacan). 
of detachment fulty described by Crabtree (1968). The chert versions have been found at other lowland sites including Tikal (Haviland 1963:428) and Barton Ramie (Willey et al. 1965:440). There are 12 complete and 12 incomplete specimens in the present collection which range in length, for the complete blades, from 5.0 to $7.1 \mathrm{~cm}$. These blades are all triangular or trapezoidal in cross section and have nearly parallel sides.

Burin Spal1s

Burin spalls are the by-products of trimming and finishing activities and are therefore included in the third manufacturing category. These specialized flakes are discussed by Semenov (1964:55; Fig. 17-5) who describes the burin blow process as intermediate between percussion and pressure. Two burin spalls were recovered, one from Ex. 33-1 and the other from Ex. 40-S.

Pressure Flakes

Bordes and Crabtree (1969:11-12) describe the manufacturing stages in the reduction and thinning of bifaces: direct percussion, indirect percussion, and pressure. No doubt there is some overlap in the morphology of the flakes produced by these techniques. However, nearly 700 flakes have been identified as the by-products of final pressure flaking of finely finished artifacts. These pressure-made waste flakes are thin, flat, and display little or no bulb of force. The count given here may not be precise because of the difficulty in distinguishing pressure flakes from other waste flakes. Borderline cases were not included in this category.

Pressure flakes comprise $41 \%$ of the collection by count and $12 \%$ of the collection by weight. Of the 698 pressure flakes recorded, 102 show macroscopic signs of wear. This figure may not indicate the proportion of utilized pressure flakes. Brose (1975) has found that certain cutting tasks leave no traces of wear on experimentally utilized flakes.

Residual Waste

The residual waste category consists of chips, chunks, amorphous fragments, and unidentified waste. Any chert specimens not described in the preceding descriptions are tabulated in this section. Residual waste accounts for about $42 \%$ of the collection by count and $29 \%$ by weight.

\section{CHERT SOURCES}

Basic to any lithic industry is a supply of suitable raw materials. Deposits of good quality chert are not distributed evenly in the Maya lowlands. The pre-Columbian stone worker in Belize was fortunate to have an arundant local supply of good to fine quality chert. One chert source is reported near Altun $\mathrm{Ha}$, at $\mathrm{Km} 24$ just off the Northern Highway out of Belize City.

Colha, immediately northwest of Rancho Creek, is the location of another chert source in the northern Belize area. Hammond (1973:57) attributes the existence of the Colha ceremonial center and workshops to the 
abundance of chert nodules in the vicinity.

One chert source is known to exist at Progresso. Hazelden (1973:77) reports grey, brown, and red cherts in the quarry. Progresso is centrally located with respect to the sites used in this analysis. In the same area chert boulders occur in beach deposits associated with the coastal strip.

Most of the specimens in the collection are classified in non-tool groups or types of marginal utility. Discarded tool blanks, flake cores, debitage, and residual waste constitute about three-fourths of the collection by count and weight. This indicates that some tool manufacturing took place at the habitation sites. It is difficult to determine what proportion of the chert assemblage was manufactured at quarry sites and what proportion was manufactured at living sites from tool blanks, large blades, and cores. However, it is clear that some core reduction and biface thinning took place at the habitation sites. The availability of local chert accounts for this. Future lithic studies in northern Belize should include visits to the chert sources in the area. More data is needed on the initial stages of tool manufacture as well as on the degree of localization and quality of exposed cherts.

Artifacts from quarry sites and workshop mounds are not included in this analysis. Of the 45 flake cores in the collection, no cores were found that had been specialiy prepared for the removal of large or prismatic blades. If blade-making activities were confined to quarries and workshops, then there may have been a degree of part-time specialization for chert workers in the area. Wilk (1975) has found evidence that there was a greater degree of craft specialization in Belize than previously believed. He has investigated a chert tool workshop at Colha containing artifacts in various stages of completion and an accumulation of chipping debris. Chopping tools were the most numerous tools found. The report makes no mention of blade-making. There may be technological differences between the Colha industry and that described here. However, it would be premature to make detailed comparisons. Neither industry is ful1y known. Future quarry surveys and workshop studies will increase our understanding of the relationships between sites and the distribution of resources.

\section{REGIONAL PATTERNS AND LITHIC TRADE}

The northern Belize collection includes several large, stemmed points. These distinctive artifacts were manufactured from large blades by modifying the proximal end into a tapered stem. Cross sections are triangular or trapezoidal as a result of their specialized detachment from prepared cores. These artifacts have a circum-Caribbean distribution and are particularly abundant in Belize (Coe 1957:280). Rovner (1975) has developed the concept of competing Tithic exchange spheres in the Maya area. The distribution of these easily identifiable large, stemmed points defines the extent of Rovner's (1975:5) Protoclassic Southern Trade Sphere. It appears that Belize may have been a center of production and distribution for these artifacts.

A number of artifacts at several sites in the Maya lowlands, particularly at Rio Bec sites, are reported to be made of Belize chert (Rovner 1975:11). 
More precise sourcing will have to be done before this is certain. Yet, there is a strong suggestion that the chert industry of Belize influenced the lithics of other regions.

\section{SUMMARY OF THE INDUSTRY}

Scraping and light cutting tools are the most common tool types in the present collection. In contrast, chopping tools are more common at other lowland sites such as Tikal, Altar de Sacrificios, Uaxactun, and Barton Ramie. Chopping and heavy cutting tools are rare in the northern Belize collection. This may be the result of the small sample size, in view of the number of chopping tools found at Colha, only 30 kilometers to the southeast. However, Proskouriakoff (1962:418-419) notes a similar rarity of chopping tools at Mayapan. In addition, the distinctive arrow points of the Postclassic Period are common to both Mayapan and northern Belize. Lithic similarities between Mayapan and northern Belize suggest an exchange of influence or similar technological circumstances. This should be tested with larger collections in future studies.

The arrow points in the Postclassic component of this collection were manufactured from prismatic blades. Identical points have been found in the Maya area as far south as Chalchuapa, El Salvador (Sheets 1975b:337) and as far north as Mayapan (Proskouriakoff 1962:360, 369). In a11 cases, these arrow points are dated to the Postclassic Period.

The availability of local chert permitted a chert industry to operate without a reliance upon long distance trade for raw 1 ithic material. Initial core reduction and production of tool blanks probably took place at the quarries. It is clear that further working of some of the chert took place at the quarries while some tool blanks, flake cores, and large blades were distributed to non-quarry sites.

The first stage of manufacture involves the preparation and reduction of cores. This activity produces large blades, large flakes, and tool blanks. Some of these are worked further, or they are transported or used without modification.

The products of the first stage of manufacture are worked in the second stage into tools of crude or intentionally general form. It may be that these tools were intended for the least specialized tasks. The by-products of this second stage of manufacture are used or worked into finer, more specialized tools. The third manufacturing category embraces those tools that are carefully finished. Tools in this category could become broken and reworked into other tools, or they could become dull and rejuvenated. But for the purposes of the typology used in this analysis the third manufacturing category includes only those tools that display chipping of high quality, usualiy the result of pressure flaking, and that have taken on a specific form. Thus, large bifacial choppers and tiny arrow points are the products of the same stage of manufacture. Temporal and spatial changes in the industry are difficult to recognize. A larger sample will allow a more detailed analysis of the industry. 
Figures 3 and 4 summarized the brief description of the industry as presented above. There are several detailed behavioral models for some Mesoamerican 1ithic industries (Hester 1974; Sheets 1975b; Wi1k 1975). The generalized model in Figs. 3 and 4 should not be compared to the more detailed behavioral models. The model presented here was developed only to aid in structuring the typology and not to thoroughly reconstruct the various paths a tool might take during production.

\section{CONCLUSIONS}

The purpose of the analysis of this collection is to provide a systematic description of chert artifacts from northern Belize and to outline the major aspects of the pre-Columbian industry of the area. There is a lack of behavioral and technological analyses of Maya chert industries. There are a number of such analyses of obsidian industries and this report has been influenced by these studies. It should, of course, be remembered that the problems encountered in working and using chert are not always the same as those encountered with obsidian.

Oswalt (1973:21) contends that man is basically a technological animal and that the major distinctions among cultures should be made on the basis of manufactured forms. Sheets $(1975 \mathrm{~b}: 378)$ stresses that regional models of lithic industries should be developed. This paper is a start in that direction for Maya chert industries and I hope that future studies will improve on my methods and findings.

\section{ACKNOWLEDGEMENTS}

I thank Dr. David C. Grove of the Department of Anthropology, University of Illinois, Urbana, for providing laboratory space; Dr. Warren Peterson, Department of Anthropology, University of Illinois, for his valuable guidance during the analys is of this collection; and Dr. Payson Sheets, Department of Anthropology, University of Colorado, Boulder, for his helpful comments and criticisms of an earlier draft of this report. I am indebted to Raymond Sidrys for editing various drafts of this report and for his valuable and patient guidance during all phases of the 1974 UCLA Survey of the Corozal District. I thank Mr. Joseph 0. Palacio, Archaeological Commissioner of Belize, and the Honorable A. A. Hunter, Department of Trade and Industry, for their valuable assistance and cooperation during the course of the 1974 UCLA Survey.

\section{REFERENCES CITED}

Andresen, J. M.

1974 A Preliminary Analys is of Chipped Flint Artifacts From Northern Belize. On file at the Department of Anthropology, University of Illinois, Urbana.

Bordes, F. and D. Crabtree

1969 The Corbiac Blade Technique and Other Experiments. Tebiwa $12(2): 1-21$. 
Brose, D.

1975 Functional Analysis of Stone Tools: A Cautionary Note on the Role of Animal Fats. American Antiquity 40:86-94.

Coe, M. D.

1966 The Maya. Praeger, New York.

Coe, W. R.

1957 A Distinctive Artifact Common to Haiti and Central America. American Antiquity 22:280-282.

Crabtree, D.

1968 Mesoamerican Polyhedral Cores and Prismatic B7ades. American Antiquity 33:446-478.

Epstein, J.

1964 Towards a Systematic Description of Chipped Stone. Actas $y$ Memorias, XXXV Congreso Internacional de Americanistas:155169. Mexico.

Graham, J. and R. Heizer

1968 . Notes on the Papalhuapa Site, Guatemala. Contributions of the University of California Archaeological Research Facility $5: 107-125$.

Hammond, N. (ed.)

1973 Corozal Project Interim Report. Centre of Latin American Studies, Cambridge University.

Haviland, W.

1963 Excavation of Smal1 Structures in the Northeast Quadrant of Tikal. University Microfitms, Ann Arbor.

Hazelden, J.

1973 The Soils and Geology of the Orange Walk and Corozal Districts. In: Corozal Project Interim Report (N. Hammond, ed.):74-85.

Hester, T. R.

1972 Notes on Large Obsidian Blade Cores and Core-Blade Technology in Mesoamerica. Contributions of the university of California Archaeological Research Facility 14:95-106. 
1974 The Obsidian Industry of Beleh (Chinautla Viejo), Guatemala. Actas, XLI Congreso Internacional de Americanistas I:473488. Mexico.

Kidder, A.

1947 The Artifacts of Vaxactun, Guatemala. Carnegie Institute of Washington Publication 576.

Lee, $T$.

1969 The Artifacts of Chiapa de Corzo, Chiapas, Mexico. Papers of the New World Archaeological Foundation 26.

Oswalt, w.

1955 Prehistoric Sea Mamma1 Hunters at Kaflia, Alaska. Anthropological Papers of the University of Alaska 4:23-61.

1973 Habitat and Technology. Holt, Rinehart, and Winston, New York.

Proskouriakoff, T.

1962 The Artifacts of Mayapan. In: Mayapan, Yucatan, Mexico (H. Pollock, ed.). Carnegie Institute of Washington Publication 619:321-442.

Rovner, I.

1975 The Cyclical Rise and Fall of Maya Lithic Trade Spheres. Paper presented at the 40th Annual Meeting of the Society for American Archaeology, Dal1as.

Semenov, S.

1964 Prehistaric Technology. Redwood Press, London.

Sheets, P.

1975a New World Lithic Analysis Symposium: Southern Mesoamerica. Paper presented at the 40th Annual Meeting of the Society for American Archaeology, Dallas.

1975b Behavioral AnaTysis and the Structure of a Prehistoric Industry. Current Anthropology 16:369-391.

Wi k, R.

1975 Superficial Examination of Structure 100, Colha. In: Archaeology in Northern Belize (N. Hammond, ed.):152-173. Centre of Latin American Studies, Cambridge University. 
Willey, G.

1972 The Artifacts of A7tar De Sacrificios. Papers of the Peabody Museum, Harvard University 64.

Wil7ey, G., W. But7ard, J. Glass, and J. Gifford

1965 Prehistoric Maya Settlements in the Belize Valley. Papers of the Peabody Museum, Harvard University 54. 


\section{METATE IMPORT IN NORTHERN BELIZE}

Raymond Sidrys and John Andresen

\section{INTRODUCTION}

Grinding stone implements were necessary to every Mesoamerican household because of maize-dominated subsistence. ATthough manos and metates are commonty recovered in lowland Maya excavations, few studies have investigated the geographic and diachronic distribution of imported grinding stone. Such studies are valuable as they reveal the availability of a long distance trade good to the average Maya farmer.

This study reports on the geological sources of grinding stone artifacts from several sites in northern Belize. The findings are compared to other Maya lowland sites. The northern Belize material consists of 122 metate and 144 mano fragments found during the 1974 UJCLA Corozal Survey. A11 of the grinding stone artifacts encountered in the survey came from utilitarian contexts such as surface locations, sherd dumps, middens or construction fill.

The grinding stone data were analyzed for the following variables: (1) temporal context, (2) general geological source area, (3) morphological form, and (4) physical dimensions. For future statistical permutations, the complete raw data can be found in Sidrys (1976: Fig. 83). Data Tists of this sort, from all recent and on-going Mesoamerican excavations, should be compiled in a centralized computer data bank. This would facilitate future scholarly research through: (1) a greater availability of generally unpublished field data, and (2) the standardization of certa in data classification methods. A regional data bank of this sort has a Tready been established (SELGEM) by American archaeologists in the U.S. Southwest. In the Maya sphere, only the Pennsylvania State University Kaminaljuyu Project has established a computer data bank (Michels and Sanders 1973:6).

\section{METHODOLOGY}

The methodology of the study will be discussed prior to the presentation of the findings. Most of the ground stone was classified in the field laboratory and it is now stored in Belize. It should be noted that few complete metates were found, and that the largest fragment weighed on $7 y$ about $5 \mathrm{~kg}$. The average fragment probably weighed less than $.5 \mathrm{~kg}$ (the fragments were not weighed). The small size of the metate fragments, in some cases, caused ambiguity as to the morphological form. Accordingly, this variable is the weakest aspect of our metate classification scheme. Although few complete manos were found, most of the fragment sizes were sufficient for shape identification. The classification of metate and mano shapes generally followed the typologies used at Barton Ramie and A1tar de Sacrificios (Wi1ley et al. 1965:453-465; 1972:106-124). The five metate forms (Fig. 1) include the turtleback form with a rounded base (TB); the trough-shaped form with a flat base (TS); the thin-flat legless form $(T)$; the thin-flat legged form $(L)$; and the thin-flat grooved form 


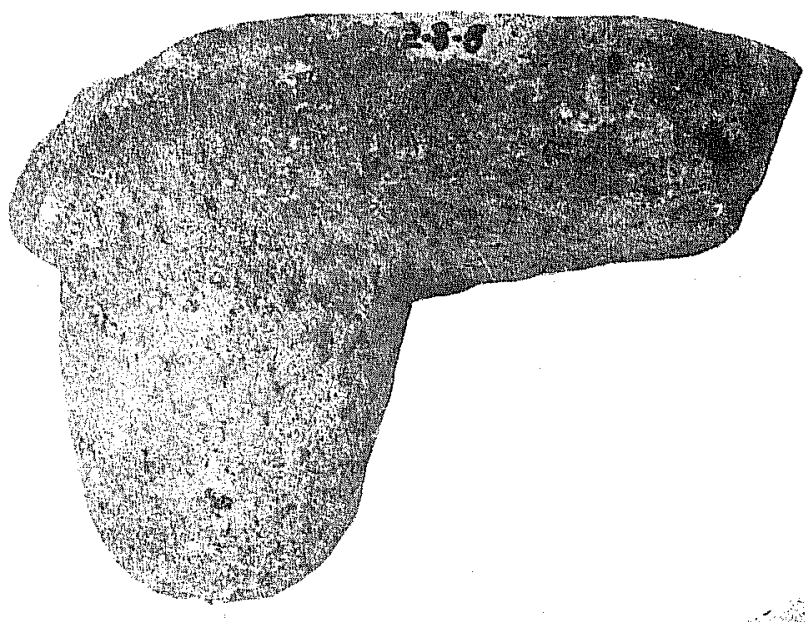

a

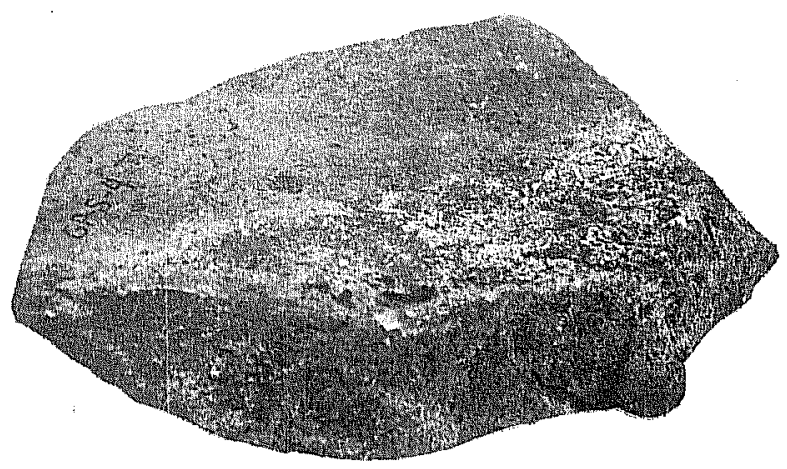

e

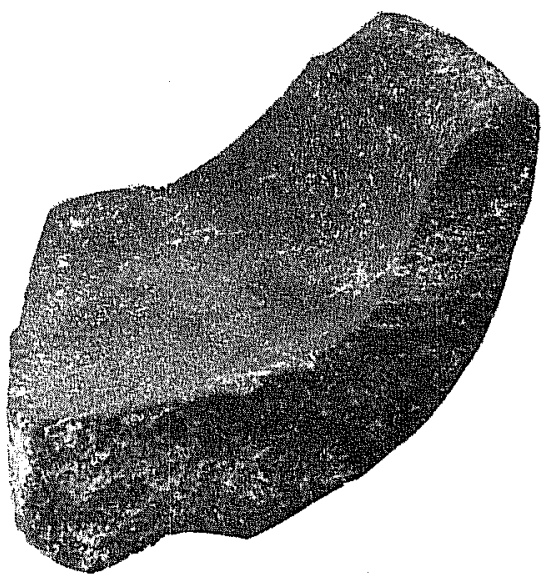

b
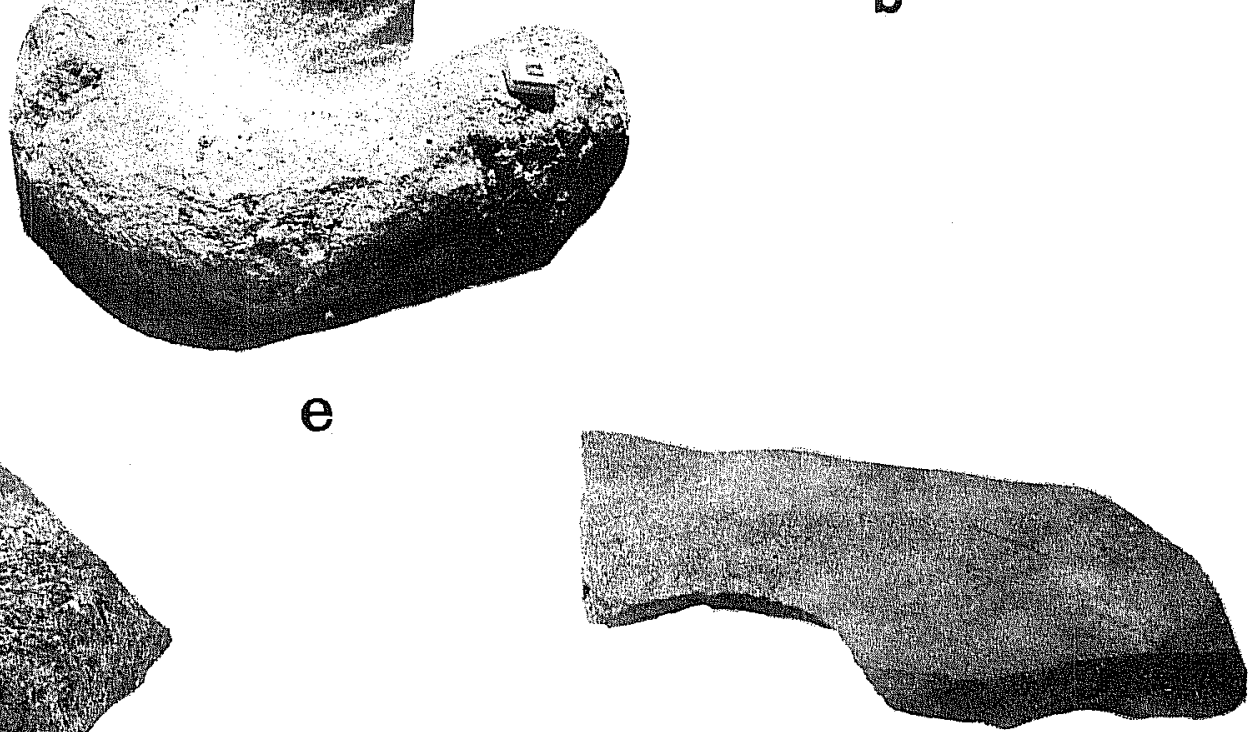

$\mathbb{C}$

d

igure 1. Representative metate types. (Not to scale). a, Thin-legged (L), Ex. 2-S-5 t Aventura. b, Turtleback (TB), Ex. 6-2-2 at Aventura. C, Thin-Flat (T), Ex. GP-S-4 TS), Ex. 41-S at Sta. Rita Corozal; d,e, other metate forms. 
(G). It is possible that some of the fragments classified as the thin-flat legless form actually belong to the thin-flat legged form, as the leg evidence was occasionally ambiguous. The eight mano shapes (Fig. 2) include oval (0); circular (C); plano-convex (PC); rectangular $(R)$; square $(S)$; triangular $(T)$; pentagonal $(P)$; and overhand or knobended (OV). The shape determination was made primarily on the basis of transverse cross sections.

Qualitative size determinations (i.e., subdivision into large or small varieties) were not made for either manos or metates. Rather, a standardized series of measurements were taken on each fragment to allow quantitative size comparisons within and between types. For the metates the first measurement consisted of its thickness at a point about onefourth of its transverse length, or its "end-thickness" (ET). The second measurement was the "middle-thickness" (MT), near the middle of its transverse length. To some degree these measurements merely reflect the variation in the depth of the grinding basin, which is substantial in the larger metates (Wi1ley 1972:106-108). Nevertheless, they appear to be the best data that are available for small fragments. The mano measurements are more straightforward. They consist of the height $(H)$ and width $(W)$ of the transverse cross section. However, a slight measurement problem does exist as the cross section varies along the longitudinal axis between fragments.

Few conclusions could be drawn from either the metate or mano measurements (see Sidrys 1976: Figs. 77 and 79). The largest metate type was the trough-shaped form, followed by the thin-flat legged, the turtleback, and the thin-flat legless. The size variation within most of the metate and mano forms is quite large.

The ground stone fragments were assigned to five time periods. These include a Late Preclassic Period (1) at 300 B.C.-A.D. 250; an Early Classic Period (2) at A.D. 250-A.D. 600; a Full Classic context (3), A.D. 250-A.D. 900, for those fragments that could not be securely assigned to an Early or Late phase; a Late Classic context that probably extended into the Early Postclassic (4), roughly A.D. 600-A.D. 1250; and a Late Postclassic Period (5) at A.D. 1250-A.D. 1450. Many of the excavation levels were somewhat "mixed" in terms of ceramic phase. Accordingly, in some cases temporal context had to be assigned on the basis of the largest ceramic phase proportion present. Most of the ground stone dates to Period 4 . The Late Preclassic sample includes only one metate and one mano.

Most of the simple geological characterization was done by the authors in the field laboratory. Chips of unidentified samples (c. 20) were brought back and examined under polarized light microscopes by several UCLA geologists. These individuals informed us that even their identifications are somewhat tentative as no definitive chemical analyses were performed. However, the prime objective of our geological characterization was simply to separate the ground stone into three general geological "sources" that were used by the Maya. Clearly, geological analyses of archaeological artifacts should have the goal of discriminating between Maya "emic" sources rather than producing "etic" geological 


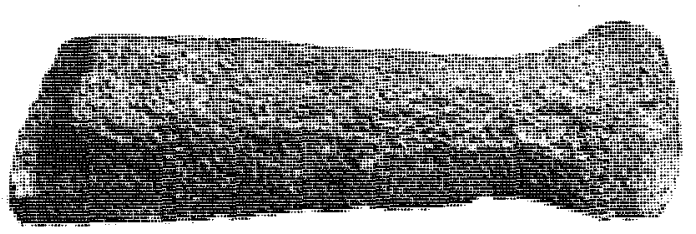

a

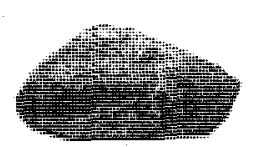

b

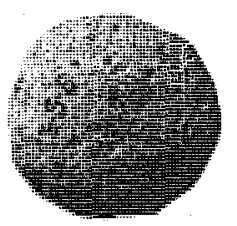

e

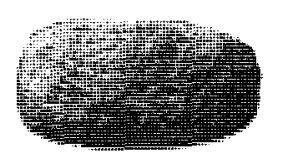

C

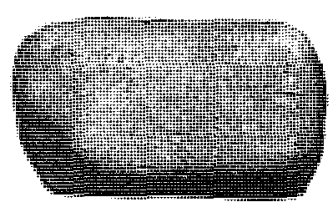

$f$

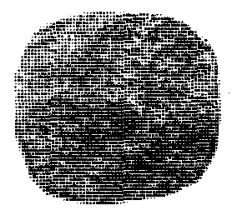

d

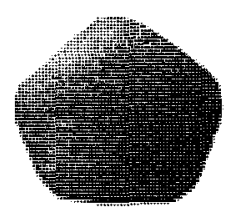

$\mathbf{g}$

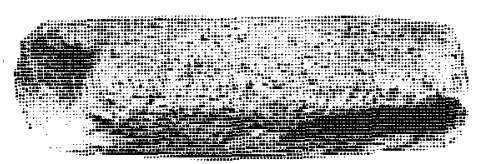

h

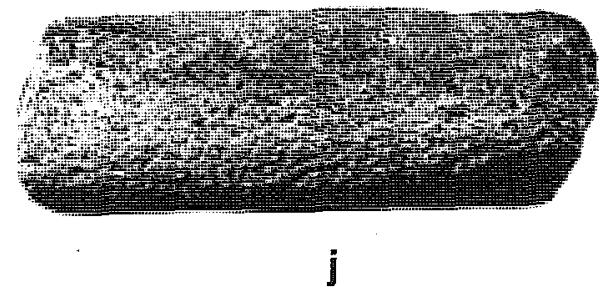

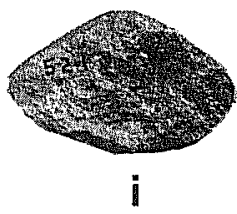

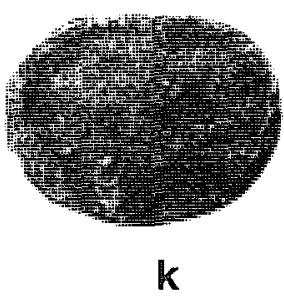

igure 2. Representative mano types. (Not to scale). a, Overhang, longitudinal view, x. 3-2-1 at Aventura. b, Triangular, cross section, Ex. 9-2-2 at Patchchacan. c, ectangular, cross section, Ex. 31-1-3 at Chan Chen. d, Square, cross section, Ex. -1-4 at Patchchacan. e, Circular, cross section, Ex. 13-5-5 at Patchchacan. $f$, Penagonal, longitudinal view, Ex. 15-1-B-1 at Patchchacan. g, Pentagonal, cross section $f \mathrm{f}$. h, Plano-Convex, longitudinal view, Ex. 5-2-1 at Aventura. i, Plano-Convex, ross section, Ex. 9-5-1 at Patchchacan. j, Oval, 1ongitudinal view, Ex. 23-S at Chan hen. $k$, Oval, cross section, Ex. GP-S-1 at Aventura. 
categories. Of course, a comprehensive geological characterization of an artifact will be useful in the future for more precise outcrop Tocalization (and should be done whenever possible). We wish to stress, however, that the type of geological "sourcing" analysis that is presently most useful to Mayan field archaeologists is not very complex (recognition of basic types can be learned in about an hour in a geology Taboratory).

An awareness of one particular concept is critical. The classic three geological divisions of rock are sedimentary, metamorphic and igneous. Within the lowland Maya sphere the categorization of a rock artifact as either sedimentary or metamorphic is general1y adequate. However, igneous rocks can be either intrusive or extrusive. Whereas igneous extrusive are those discharged by a volcano or a vent, igneous intrusives are forced into another subterranean stratum and are not ejected onto the surface. Since igneous intrusives are found in the Maya Mountains, a11 use of the term igneous should be specified as to extrusive (synonomous with volcanic) or intrusive variety. One wel1-known trade study that emphasized lowland metate import failed to make this distinction. This Ted the author to apply the term "volcanic stone" to granite metates found near the Maya Mountains, which is in error since granite is an intrusive rather than an extrusive rock. In the same study, reference was made to "quartzite and other igneous materials", which also is misleading, as quartzite is a metamorphic rather than an igneous rock. While the existence of such errors is understandable, their frequent occurrence could distort the final summary.

For the most part, a classification of the geological sources for grinding stone artifacts in the Maya sphere wi 11 do best by making reference to a geological source region, rather than to the three classic geological types. According7y, the first source (L) is the "Tocal sedimentary rock" that occurs in northern Belize (see Hazelden 1973) as well as throughout most of the Maya lowlands. A1 1 imestone rock, some of it in varying light-colors or degrees of hardness, was placed in this category, together with some sandstone, conglomerates and shales (as well as specular hematite and iron pyrite). It should be noted that nearly a17 of the limestone metates found by the survey were of sub-crystalline limestone. This finding refutes an earlier statement that such metates "are rarely found since natural limestone is too soft to be efficient" (Rathje 1972: 388).

The second source (M) is the metamorphic and igneous intrusive region of the Maya Mountains (Dixon 1955:35-48) in central and western Belize that is located at a minimum 1 inear distance of $150 \mathrm{~km}$ from Aventura. A11 metamorphic ground stone artifacts such as gneiss, quartzite, slate and schist, as well as such igneous intrusives as granite and porphyry were assumed to have been imported from this region. Thompson (1970:140) has presented some evidence of serpentine deposits in the Maya Mountains but this is uncertain. The third source $(V)$ is the volcanic highlands of southern Guatemala at a minimum 7 inear distance of $400 \mathrm{~km}$ from Aventura. The extrusive volcanics imported from this area include basalt, vesicular lava, and pumiceous or andesitic tuff (serpentine, obsidian and jade also derive from this area). Note that sma 11 blocks of pumice do occur 
at the Barrier Reef, and the inhabitants of San Pedro regularly sell them for use as abraders in laundry work. These very light low-density cobbles should not be confused with the heavier fragments of imported pumiceous tuff.

It should be understood that the assignation of an artifact to one of these three sources is not incontrovertible. It assumes a primary reliance on the nearest available resource. For example, a limestone metate designated to be of local derivation could theoretically have been imported from a distance of several hundred kilometers (of course this is unlikely). Futhermore, all of the metamorphic and igneous rocks found in the Maya Mountains are very likely to also occur near the volcanic highlands. The only certain assignation is in the category of extrusive volcanics.

The compiled ground stone data were run on standard "package" programs (SPSS, SAS) for numerous permutations of descriptive statistics and chisquare association tests. These permutations included source vs. time, form and site; time vs. form; form per site; size per site; etc. The most important results are discussed in the following sections.

Metates: Geologic Sources

A $3 \times 3$ contingency table $(n=94)$ compared the use of the three geological sources between the Late Preclassic-Early Classic, the Late Classic-Early Postclassic, and the Late Postclassic. The $x^{2}$ was significant at the .05 level and indicated that, in general, the use of some geologic sources is related to different time periods. Interestingly, source use does not seem to be appreciably different between the Late Preclassic-Early Classic and the Late Classic-Early Postclassic, as their association was not significantly different $\left(x^{2}=3.1\right)$ at the .1 level of confidence. However, a substantial change in source use does seem to occur between the Late Classic-Early Postclassic and the Late Postclassic (the $x^{2}$ of 5.8 is significant at the .1 level). Specifically this change consists of a radical increase (by a factor of 2.2) in the use of volcanic sources during the Late Postclassic, together with a substantial increase in the use of the Maya Mountains (see Table 1). The gradual increase in the import of long-distance volcanic stone (from the Early Classic onwards), together with the large decrease in use of the local stone during the Late Postclassic may reflect an evolutionary trend in the mechanics of long-distance exchange: better sea-going canoes, establishment of portsof-trade, entrepreneurial a11jances, etc.

The finding that long-distance volcanic import in the northern Belize area increased through time is also reflected in the source breakdown per site in Table 2. The three metate collections with the highest volcanic metate percentages are at Sarteneja, with a known full Postclassic occupation; Aventura, with a strong Tate Late Classic-early Early Postclassic population; and Sta. Rita, with a strong full Postclassic occupation. Caledonia and Chan Chen, both with strong Late PreclassicEarly Classic populations, follow in the sequence with volcanic percentages that are less than one-half those of the first three sites. 


\section{TABLE 1.}

Geologic Sources of Metates in Northern Belize through Time

\begin{tabular}{lcccc} 
Time Period & $\begin{array}{c}\text { Sample } \\
\text { Size } \\
(N)\end{array}$ & $\begin{array}{c}\text { Local } \\
\text { Source }\end{array}$ & $\begin{array}{c}\text { Maya Mts. } \\
\%\end{array}$ & $\begin{array}{c}\text { Volcanic } \\
\text { Source } \\
\%\end{array}$ \\
\hline 0-600 A.D. & 17 & 64.7 & 29.4 & 5.9 \\
600 A.D. - 1250 A.D. & 58 & 67.2 & 13.8 & 19.0 \\
1250 A.D. - 1450 A.D. & 19 & 36.8 & 21.0 & 42.1 \\
\hline
\end{tabular}


Patchchacan's position in last place is somewhat anomalous as it is ful1y contemporaneous with Aventura. However, as a smal1 hamlet it may not have had the resources to participate in long-distance trade.

The regional Corozal metate data are now compared with similar data from other lowland sites (see Table 2). It is significant that the average percentage of volcanic rock among the metate collections from the six Corozal region sites is double that of the seven sites in the Peten area/Usumacinta-Pasion area $(18.6 \%$ vs. 9.4\%). As the 1atter group of sites range $155-320 \mathrm{~km}$ in linear distance from the volcanic highlands whereas the Coroza 1 sites are at a $388-413 \mathrm{~km}$ range, it is apparent that some significant factor (perhaps direct seaborne transport) more than offset the distance disadvantage for the Corozal sites. The site of Chichen Itza also appears to have had a very significant trade with the volcanic highlands, especialiy in consideration of its $700 \mathrm{~km}$ source distance (Proskouriakoff 1962:337-348, 410-416). The marked disparity between its trade in volcanic rock and that of Mayapan (also a regional capital) should be noted.

While the metate collections of the Corozal region do appear to show high percentages of volcanic rock (c. $20 \%$ ) relative to other regions in the Maya lowlands, usage of the other two geologic sources must also be compared. The Corozal sites range from 147-166 km in linear distance from the known quartzite and granite deposits in the Maya Mountains. These deposits were not heavily exploited, as they account for on $7 y$ about $20 \%$ of the metates in the Corozal region. In sum, the Corozal Maya (through time) relied upon local sedimentary rock to produce about $60 \%$ of their metates.

In contrast, the majority of metates in the Peten area were of stone imported from the Maya Mountains. Granite and quartzite were primarity used, usually one being present almost exclusively. Tikal $(n=48)$ used 71\% quartzite and 12\% granite (Havi1and 1963:450-451). Simi1ar7y, Yaxha (in excavations conducted by the senior author in 1971) had a quartzite: granite ratio of $4: 1$, while Barton Ramie $(n=108)$ had only $2 \%$ quartzite and $94 \%$ granite. One source of quartzite is at Baldy Beacon in the Maya Mountains of Belize (Dixon 1955:20), at a Tinear distance of $94 \mathrm{~km}$ from Tika1. It is unknown whether this represents the closest source to Tikal. Thompson (1939:173) writes that quartzite is abundant about $55 \mathrm{~km}$ southeast of San Jose, which would al so be about $90 \mathrm{~km}$ from Tikal and may represent the same source. The nearest granite source to Tikal is probably the Granite Basin west of the Bald Hi17s, at a Tinear distance of $72 \mathrm{~km}$. Medium-grained biotite granite is visible to depths over 50 feet here in road cuts from Ma $i$ to Augustine (Furley 1968:42-46). Barton Ramie is only some $20 \mathrm{~km}$ from granite outcrops.

It is difficult to compare the energy costs of the metate import systems of the Peten and Corozal areas. The Peten area received large numbers of metates imported at a moderate distance $(<100 \mathrm{~km})$, while the Corozal area imported relatively smal1 numbers of metates at a large distance (c. 400 $\mathrm{km})$. It is clear, however, that the average Corozal Maya had less access to imported grinding stone than did his Peten counterpart. 
TABLE 2.

Geologic Sources of Metates in the Maya Lowlands

\begin{tabular}{|c|c|c|c|c|c|}
\hline Site & $\begin{array}{l}\text { Sample } \\
\text { Size }(N)\end{array}$ & $\begin{array}{c}\text { Local } \\
(\%)\end{array}$ & $\begin{array}{l}\text { Maya } \\
\text { Mts. } \\
(\%)\end{array}$ & $\begin{array}{c}\text { Volcanic } \\
(\%)\end{array}$ & $\begin{array}{l}\text { Linear Dist. } \\
\text { From } \\
\text { Volcan. Zone }\end{array}$ \\
\hline
\end{tabular}

Usumacinta Peten

Area

\begin{tabular}{lccccc} 
Altar & 375 & c. $90 ?$ & $<10 ? 2$ & .5 & 155 \\
Piedras Negras & 20 & 85 & 0 & 15 & 220 \\
Yaxha & $14.66 \mathrm{~kg}$ & $<5$ & $>95$ & 0 & 260 \\
Barton Ramie & 108 & 0 & 100 & 0 & 280 \\
Tika1 & $>2000$ & c. 15 & c.80? & "some" & 285 \\
Uaxactun & 13 & 33.3 & 403 & 26.7 & 305 \\
San Jose & 14 & 7.1 & $78.6^{3}$ & 14.3 & 320 \\
\hline
\end{tabular}

Northern Belize

Region

\begin{tabular}{lrllll} 
Sarteneja & 7 & 42.9 & 28.6 & 28.6 & 405 \\
Aventura & 42 & 64.3 & 7.1 & 28.6 & 400 \\
Sta. Rita & 29 & 58.6 & 13.8 & 27.6 & 408 \\
Caledonia & 8 & 62.5 & 25.0 & 12.5 & 388 \\
Chan Chen & 10 & 70 & 20 & 10 & 413 \\
Patchchacan & 23 & 73.9 & 21.7 & 4.3 & 410 \\
\hline & & & & & \\
rth Yucatan & & & & & \\
Mayapan & 747 & 97.2 & 0.4 & 2.4 & 680 \\
Chichen Itza & 42 & 85.7 & 0 & 14.3 & 700
\end{tabular}

1 Most of the grinding stone fragments $(n<100)$ excavated at Yaxha by the senior author were very small and were recorded by mass. Some of these fragments may represent manos as well.

2 The small percentage of quartzite found at Altar may have come from a closer highland source rather than the Maya Mountains.

3 The sandstone metates at Uaxactun and San Jose were classified as from the Maya Mountains. 
TABLE 3.

Geologic Sources of Manos in the Maya Lowlands

\begin{tabular}{lcccc} 
Site & $\begin{array}{c}\text { Sample } \\
\text { Size(N) }\end{array}$ & $\begin{array}{c}\text { Local } \\
(\%)\end{array}$ & $\begin{array}{c}\text { Maya Mts. } \\
(\%)\end{array}$ & $\begin{array}{c}\text { Volcanic } \\
(\%)\end{array}$ \\
\hline Usumacinta-Peten Area & & & & \\
Altar & & & & 0 \\
Piedras Negras & 542 & c. $90 ?$ & $<10 ?$ & 0 \\
Barton Ramie & 9 & "some" & "some" & 0 \\
Tikal & 249 & 0 & 100 & 0 \\
Uaxactun & 49 & 14.3 & 83.7 & 2 \\
San Jose & 56 & 66 & 32 & 0 \\
\hline
\end{tabular}

Northern Belize Region

$\begin{array}{lcccl}\text { Sta. Rita } & 24 & 87.5 & 4.2 & 8.3 \\ \text { Aventura } & 65 & 95.4 & 3.1 & 1.5 \\ \text { Sarteneja } & 6 & 67 & 34.0 & 0 \\ \text { Patchchacan } & 29 & 93.1 & 6.9 & 0 \\ \text { Chan Chen } & 15 & 100 & 0 & 0\end{array}$

North Yucatan

$\begin{array}{lrrlr}\text { Mayapan } & 54 & 85.2 & 0 & 14.8 \\ \text { Chichen Itza } & 227 & 98.2 & 0.4 & 1.3\end{array}$


Metates: Forms

In the total collection $(n=110)$ the turtleback form appeared to be the most common (45\%), closely followed by the thin-flat legless form $(41 \%)$, with the thin-flat legged form $(10 \%)$, the trough-shaped form $(3 \%)$ and thin-flat grooved form (2\%) appearing in smal1 quantities. One should note that some of the $T$ fragments may belong to the $L$ category. Because of this factor, as well as the insufficient sample size in two of the groups, the $x^{2}$ results in the TypexTime permutations were not used. However, comparative observations in the literature show that the thinflat legless form is not frequently present in the lowlands, but that it does seem to appear at the Tabasco region, Palenque, and San Jose at a Late Classic or Terminal Classic date (Wi1ley 1972:115). Half of our thinflat legless sample $(n=38)$ also date to this period. However, they appear to have been commonly used during other time periods as we11. Since the TB form is the "overwheimingty common metate type in the Peten" and the TS and L forms are more common in north and west Yucatan (Willey 1972:115), the metate distribution in northern Belize appears to share the Peten tradition more so than that of north Yucatan.

Metate form appeared to be related to geological source. This is indicated by a $3 \times 5$ contjingency table of sources and types $(n=110)$ which gave a significant $x^{2}$ at the .05 leve 1 . It is presumably metate size, as related to metate form, that is the actual factor involved here. It is clear that the smallest and lightest morphological forms, such as the $T$ or $\mathrm{L}$ form, would have been the most economically desirable for longdistance transport.

The largest metates found were of the TS form, and all three of these were of 7 ocal limestone. The TB form averaged the second largest, and was the most common mode for local stone (TB form comprised $44 \%$ of the $L$ source) as well as for stone from the Maya Mountains (83\% of the M source). Volcanic stone was principaliy used for the lighter $T$ form ( $T$ form comprised $58 \%$ of $V$ source) and although some volcanic stone did appear in the TB form (28\% of $V$ source) at least half of this sample had been quarried from a lightweight andesitic or pumiceous tuff. Finally, it should be noted that the $L$ form had a nearly identical geological source breakdown to the $T$ form. This suggests, as previously mentioned, that some fragments within these two categories were not correctly sorted.

Manos

In comparison with metate trade, there was very little long-distance import of manos in northern Belize (contrast Tables 2 and 3 ). More than $90 \%$ of the manos at each site were of 10cal 1imestone; only 10 imported manos were found. As the same three sites, Sta. Rita, Aventura, and Sarteneja, had both the highest metate and mano import frequencies it is likely that imported manos were simply fashioned from discarded imported metates. Sta. Rita appeared as the leader in mano import with one basaltic tuff mano (37-2-5), one vesicular lava (FE2-S), and one quartzite $(35-4-1)$. Aventura had one volcanic tuff (2-6-1), one of grey quartzite 
(1-7-11), and one sandstone (3-S-7); Sarteneja had one of white granite (Sart-B-2) and one black granite (Sart-B-3); and Patchchacan had one of white granite (10-2-1) and one of brown quartzite (15-1-B-3). Other lowland sites share the same pattern: relative to volcanic metates there is very little volcanic mano import. The sole exception is Mayapan where $15 \%$ of the mano collection was volcanic stone (note that five lava pounding stones found at that site were not included with the mano total).

The mano total ( $n=125$ ) from five Belizean sites shows the following cross sectional shape frequencies: Oval (28\%), Circular (22.4\%), Rectangular $(27.6 \%)$, Square $(9.6 \%)$, Plano-convex $(8 \%)$, Overhand (4\%), Pentagonal $(4 \%)$, Triangular $(2.4 \%)$. The Oval form was the most common at Aventura (36.9\% of site tota 1 ) and at Sarteneja (50\%). The Rectangular form occurred most frequently at Sta. Rita (25\%), Patchchacan (20.7\%) and Chan Chen (33.7\%). Since shape determination is partially an arbitrary process we are unsure of the significance of the shape frequencies, especially in regard to intersite comparisons or chronological evolution. For example, a "square" form is occasionally nearly indistinguishable from an "ova7" or a "rectang7e" (Willey et al. 1965:462-465 have remarked on similar difficulties).

During the Early Classic $(n=11)$ the Rectangular form was the most common $(55 \%)$. The Late Classic-Early Postclassic $(n=68)$ appeared to indicate a shift to the Oval and Circular forms (each with 37\%), but the Late Postclassic $(n=19)$ once again had the Rectangular form $(48 \%)$ as the most common mano shape. Wi1ley $(1965: 465,1972: 124)$ has noted somewhat of a trend in the Late Classic in the replacement of circular, oval and flattish mano forms wi th rectangular or square sectional forms. Clearly the temporal pattern from the present study does not fit this trend.

In one sense the mano shape frequencies appeared to corroborate well with the metate type frequencies. One would expect a curvilinear crosssectional mano shape to be associated with a curvilinear grinding trough (e.g. TB), and the polygonal cross sectional mano shapes to be associated with the flatter grinding troughs (e.g. L or T). We found that the frequency of TB + TS curvilinear troughs ( $48 \%$ of total metates) does compare favorably with the Oval + Circular mano frequency (50\% of total manos). Likewise the $T+L+G$ flat grinding trough frequency (52\%) compared favorably with the frequency $(50 \%)$ of those manos with at least one planar surface, the $R+S+P+T+0 v+P-C$ forms. Finally, the occurrence of the Overhang mano form, which is specialized for a thin-flat legged metate (Wi1ley 1972:124) compared we11 (4\%) with the frequency of the $L$ metate form $(10 \%)$. However, these good correspondences may be coincidental as Willey (1972:124) has noted that at Altar almost all mano shapes (excluding Ov) could have been used with the TB+TS curvilinear troughs.

In summary, the metate collections of several sites in the Corozal District of northern Belize show some of the highest percentages of volcanic metates in the Maya lowlands. The import of volcanic rock in the area increased through time and reached its peak during the Late Postclassic. The Corozal Maya, however, did rely upon local sedimentary rock to produce about $60 \%$ of their metates. In contrast, the Peten Maya imported the 
majority of their metates, although from a lesser distance $(<100 \mathrm{~km})$. While the energy costs of the two import systems are difficult to compare, it seems that the average Corozal Maya had less access to imported grinding stone than did a Tikal Maya.

\section{REFERENCES CITED}

Dixon, C.

1955 The Geology of Southern British Honduras. Government Printer, Belize.

Furley, P.

1968 The University of Edinburgh British Honduras-Yucatan Expedition. The Geological Journal 134:38-53.

Haviland, W.

1963 Excavations of Sma11 Structures in the Northeast Quadrant of Tikal, Guatemala. Ph.D. Dissertation, Department of Anthropology, University of Pennsylvania.

Haze1den, J.

1973 Soils and Geology of the Orange Walk and Corozal Districts. In: British Museum-Cambridge University Corozal Project (ed. by N. Hammond):74-84. Centre of Latin American Studies, University of Cambridge.

Michels, J. and W. Sanders (eds.)

1973 Pennsylvania State University Kamina1juyu Project-1969, 1970 Seasons: Part 1 - Mound Excavations. Occasional Papers in Anthropology. Pennsylvania State University 9.

Proskouriakoff, T.

1962 Artifacts of Mayapan. Carnegie Institution of Washington, Publication 619.

Rathje, W. L.

1972 Praise the Gods and Pass the Metates: A Hypothesis of the Development of Lowland Rainforest Civilizations in Mesoamerica. In: Contemporary Archaeology (ed. by M. P. Leone): 365-392.

Sidrys, R.

1976 Mesoamerica: An Archaeological Analys is of a Low-Energy Civilization. Ph.D. Dissertation, Department of Anthropology, University of Cal ifornia, Los Angeles. 
Thompson, J. E. S.

1939 Excavations of San Jose, British Honduras. Carnegie Institution of Washington Publication 506.

1970 Maya History and Religion. University of 0klahoma Press, Norman.

Willey, G. R.

1972 The Artifacts at Altar de Sacrificios. Papers of the Peabody Museum, Harvard university 64(1).

Willey, G. R., W. Bullard, Jr., J. Glass, and J. Gifford

1965 Prehistoric Maya Settlements in the Belize Valley. Papers of the Peabody Museum. Harvard University 54.

\section{ACKNOWLEDGEMENTS}

For permission to transport some of the ground stone collection to UCLA, we are grateful to the Government of Belize, especially to the Archeological Commissioner, Mr. Joseph 0. Palacio, as we11 as the Hon. A. A. Hunter, Minister of Trade and Industry. We also thank Dr. L. Rosenfeld, B. Holman, and especially T. Tucker, all from the UCLA Department of Geology, for providing some of the geological identifications. 